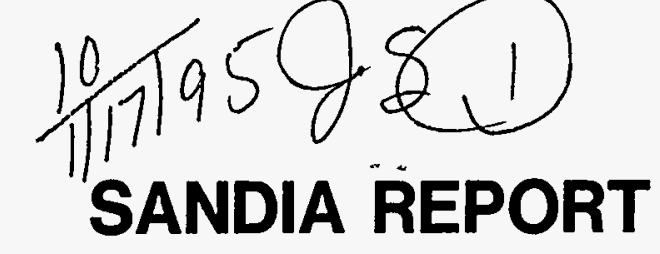

SAND92-2470 $\cdot$ UC -721

Unlimited Release

Printed November 1994

\title{
Intermediate Scale Borehole (Room C): In Situ Data Report (January 1989 - June 1993)
}

Darrell E. Munson, Tracy L. Christian-Frear, Glenn T. Baird, Duane A. Labreche, John R. Ball, Robert L. Jones, Christine L. Northrop-Salazar

Prepared by

Sandla Natlonal Laboratorles

Albuquerque, New Mexico 87185 and Llvermore, Callfornla 84550

for the United States Department of Energy

under Contract DE-AC04-94AL85000

Approyed for public release; distribution is unlimited.
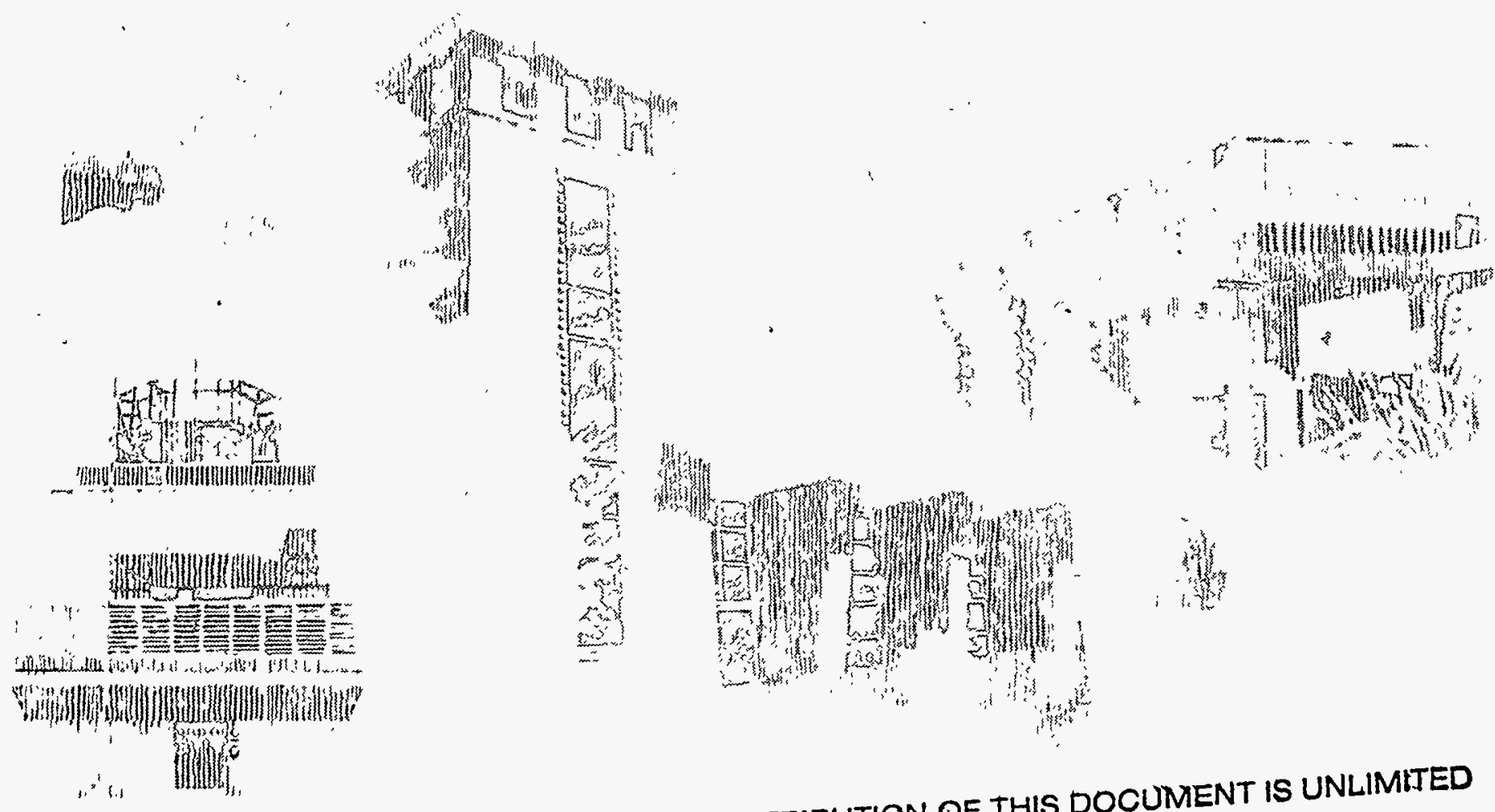
Issued by Sandia National Laboratories, operated for the United States Department of Energy by Sandia Corporation.

NOTICE: This report was prepared as an account of work sponsored by an agency of the United States Government. Neither the United States Government nor any agency thereof, nor any of their employees, nor any of their contractors, subcontractors, or their employees, makes any warranty, express or implied, or assumes any legal liability or responsibility for the accuracy, completeness, or usefulness of any information, apparatus, product, or process disclosed, or represents that its use would not infringe privately owned rights. Reference herein to any specific commercial product, process, or service by trade name, trademark, manufacturer, or otherwise, does not necessarily constitute or imply its endorsement, recommendation, or favoring by the United States Government, any agency thereof or any of their contractors or subcontractors. The views and opinions expressed herein do not necessarily state or reflect those of the United States Government, any agency thereof or any of their contractors.

Printed in the United States of America. This report has been reproduced directly from the best available copy.

Available to DOE and DOE contractors from

Office of Scientific and Technical Information

PO Box 62

Oak Ridge, TN 37831

Prices available from (615) 576-8401, FTS $626-8401$

Available to the public from

National Technical Information Service

US Department of Commerce

5285 Port Royal Rd

Springfield, VA 22161

NTIS price codes

Printed copy: A09

Microfiche copy: A01 


\section{DISCLAIMER}

Portions of this document may be illegible in electronic image products. Images are produced from the best available original document. 


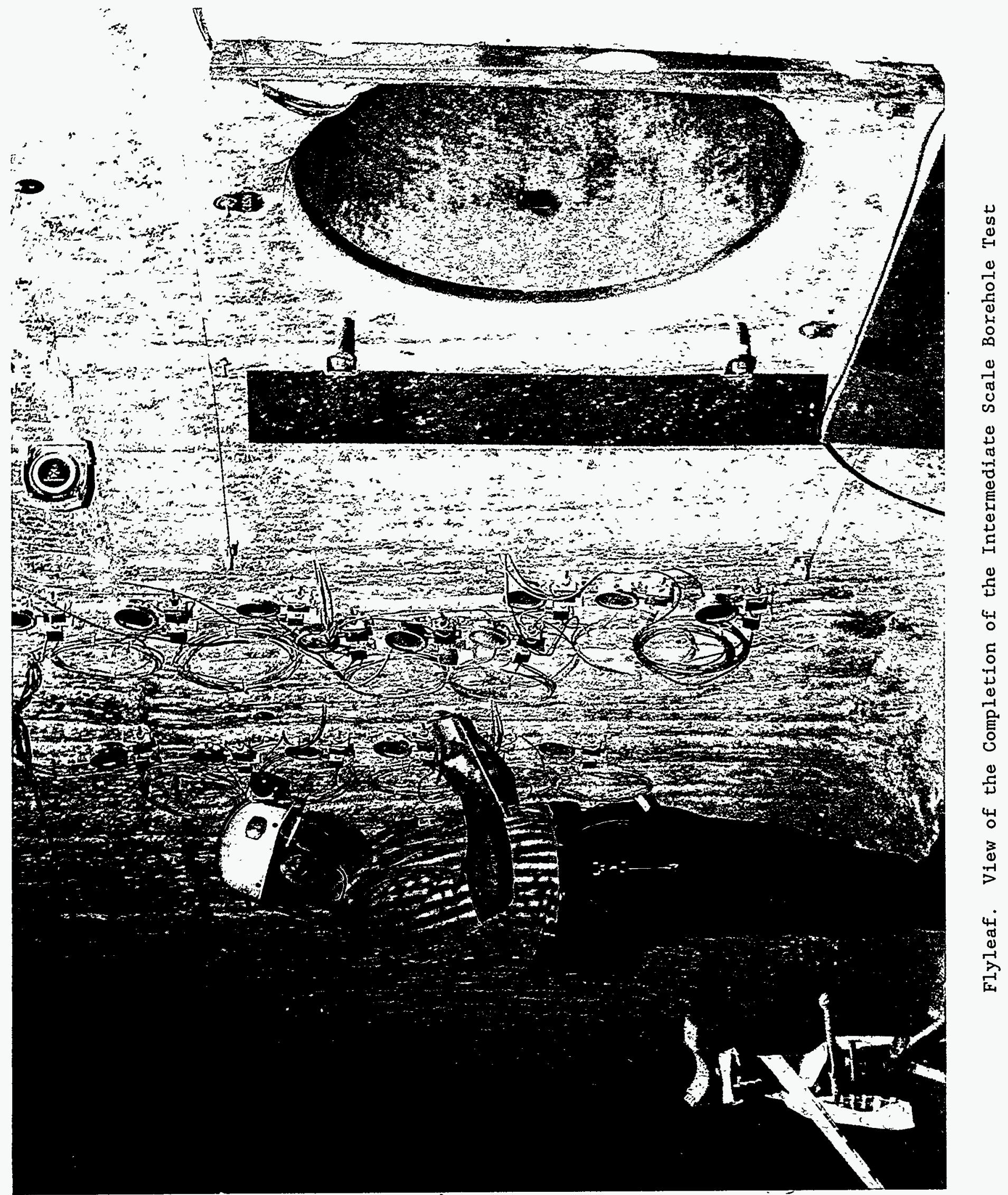


SAND92 -2470

Unlimited Release

Printed November 1994

INTERMEDIATE SCALE BOREHOLE (ROOMS C):

IN SITU DATA REPORT

(JANUARY 1989 - JUNE 1993)

WASTE ISOLATION PILOT PLANT (WIPP)

THERMAL/STRUCTURAL INTERACTIONS PROGRAM

Darre11 E. Munson

Repository Isolation Systems Department

Sandia National Laboratories

P.0. Box 5800, Albuquerque, NM 87185

Tracy L. Christian-Frear, Glenn T. Baird, Duane A. Labreche, and John R. Ball

$\mathrm{RE} / \mathrm{SPEC}$ Inc.

4775 Indian School NE, Albuquerque, NM 87110

Robert L. Jones and Christine L. Northrop-Salazar

Tech. Reps., Inc.

5000 Marble Avenue NE, Albuquerque, NM 87110

\begin{abstract}
Data are presented from the Intermediate Scale Borehole Test, an in situ test fielded in the pillar separating Rooms $\mathrm{C} 1$ and $\mathrm{C} 2$ at the Waste Isolation Pilot Plant (WIPP). The test was to provide data on the influence of scale, if any, on the structural behavior of underground openings in salt. These data include selected fielding information, test configuration, instrumentation activities, and comprehensive results from a large number of gages. Construction of the test began in December 1989 , with the drilling of the intermediate scale borehole in December 1990. Gage data in this report cover the period from January 1989 through June 1993.
\end{abstract}




\section{ACKNOWLEDGMENTS}

There were a number of organizations and people that made significant contributions to the fielding and operation of this large in situ test. To the people who were involved we owe a great deal and wish to thank them for their dedication and hard work, which assured that the results of the test were absolutely outstanding.

The Waste Isolation Pilot Plant (WIPP) Project is under the auspices of the Carlsbad Area Office of the Department of Energy (CAO/DOE), which has overall responsibility for the WIPP Program. As the scientific advisor, Sandia National Laboratories (SNL) is responsible for the required technology development, a part of which involves the in situ tests.

Mining of Rooms $C$ was done by Ohbayashi-Gumi (OBG) under contract to the DOE. Geotechnical crews were initially formed under the auspices of International Technologies, and later under Westinghouse, the operating contractor for the WIPP facility. Later, the responsibility for daily test operation and maintenance was with Westinghouse, with overall test supervision by SNL and SNL support contractors.

The intermediate scale borehole instrumentation and drilling was done by the operating contractor. Cabling, instrument shed modification, and data acquisition were handled by SNL personnel with the support of contract personnel. All site aspects of gage installation were the responsibility of RE/SPEC Inc, a contractor to SNL, utilizing the support of additional contract personnel.

There are several persons we especially wish to thank: T. Schultheis, D. Fulton, and L. Krako of SNL and W. DeYonge, D. Scheirmeister, and B. Stensen of RE/SPEC. 
1 Introduction

2 Experiment Description

2.1 Test Configuration 9

2.1.1 Physical 9

2.1.2 Gages 11

2.2 Construction $\quad 17$

2.2.1 Mining and Geology 17

2.2.2 Instrumentation 35

$\begin{array}{lll}2.2 .3 & \text { Operation } & 37\end{array}$

2.3 Special Features 38

2.3.1 Principal Stations 38

2.3.2 Gage Linking 39

2.3.3 Special Gage Groups $\quad 42$

3 Data Reduction Process 43

3.1 WISDAAM System Functions $\quad 43$

3.1.1 Manual Data 43

3.1.2 Remote Data 44

3.2 Quality Assurance (QA) Requirements 44

3.2.1 Reduction Levels 45

3.2.2 Certified Data 46

4 Reduced Data Presentation $\quad 47$

5 Reduced Data $\quad 55$

5.1 Displacement Measurements 56

5.1.1 Manual (Mining Sequence) Closure Measurements 59

5.1.2 Remote Closure Measurements $\quad 69$

5.1.3 Extensometer Measurements $\quad 91$

5.2 Stress Measurements 107

$\begin{array}{lll}5.3 & \text { Strain Measurements } & 161\end{array}$

6 Interpretation Aids $\quad 167$

7 Summary 176

$\begin{array}{lr}\text { References } & 178\end{array}$ 
Flyleaf.

Figure 2.0.1.

Figure 2.1.1.

Figure 2.1.2.

Figure 2.1.3a-d.

Figure 2.1.4a-e.

Figure 2.1.5a-b.

Figure 2.2.1.

Figure 2.2.2.

Figure 2.2.3.

Figure 2.2.4.

Figure 4.0.1.

Figure 4.0.2.

Figure 5.1.1a-g.

Figure 5.1.2a-r.

Figure 5.1.3a-1.
View of the Completion of the Intermediate Scale Borehole Test
Plan View of the Underground Experimental

Area of the WIPP

Plan View of the Intermediate Scale

Borehole Test

10

Cross Section Elevations of "As Built" Test

Plan View of Instrument Locations at $\mathrm{Z}=\mathrm{x} \cdot \mathrm{xx} \mathrm{m}$

Elevation of Instrument Locations at Principal Station $\mathrm{X}=\mathrm{x} \cdot \mathrm{xx} \mathrm{m}$

Elevation of Instrument Locations through Pillar, West and East Half

Test Room Elevation with Respect to Stratigraphy

Local WIPP Horizon Stratigraphy

Isometric of Excavation Progress of the Intermediate Scale Borehole

Excavation Advance Rate of the Intermediate Scale Borehole

Illustration of Stress Plot Containing

All Level 3 Data Points

Illustration of Stress Plot with Overlapping Points Eliminated

Mining Sequence Gages C2Mxx, ISBT, Station $\mathrm{xx} \mathrm{m}$

Remote Closure Unit $\mathrm{C} 22 \mathrm{xx}$

$73-90$

Extensometer Unit C_3xx 


\section{LIST OF FIGURES (CONTINUED)}

Figure

$\underline{\text { Page }}$

Figure 5.2.1. Schematics of SGS and BuMines Stress Meters 108

Figure 5.2.2a-t. Stress Meter SGS Unit C_5xx 111-130

Figure 5.2.2u-dd. Stress Meter BuMines Unit C_6xx 131-140

Figure 5.2.2ee-nn. Stress Meter SGS Unit Cx5xx 141-150

Figure 5.2.200-ss. Stress Meter BuMines Unit C26xx 151-162

Figure 5.3.1a-d. Strain Units C2Sxx 163-166

Figure 6.0.1. Particle Trajectories for Displacements during Mining 169

Figure 6.0.2. Reconstruction Schematic for

Closure Measurements 171

Figure 6.0.3. Reconstruction Schematic for

Extensometer Measurements 172

Figure 6.0.4. Schematic of Stress Field Perturbations 174 
Table 2.1.1.

Gage Summary 15

Table 2.3.1.

ISBT Gages Grouped by Principal Stations

Table 5.1.1. ISBT Mining Sequence Closure Gages

Location Guide 60

Table 5.1.2a-g Mining Sequence Gages C2Mxx, ISBT, Station $\mathrm{xx} \mathrm{m}$ $62-68$

ISBT Remote Closure Gages Location Guide 70

Table 5.1.3. Remote Closure Unit C22xx 73-90

Table 5.1.4a-r Extensometer Units (Gages) Location Guide

Table 5.1.6a-1.

Extensometer Unit C_3xx $95-106$

Table 5.2.1.

Stress Meter Units (Gages) Location Guide 109

Table 5.2.2a-t

Stress Meter SGS Unit C_5xx

$111-130$

Table 5.2.2u-dd.

Stress Meter BuMines Unit C_6xx

$131-140$

Table 5.2.2ee-nn.

Stress Meter SGS Unit $\mathrm{Cx} 5 \mathrm{xx}$

141-150.

Table 5.2.200-ss.

Stress Meter BuMines Unit C26xx

$151-156$

Table 5.2.3.

Direction Cosines for Unit Normals of SGS Stress Meters

Direction Cosines for Unit Normals of BuMines Stress Meters 158

Table 5.3.1. Strain Gage Units (Gages) Location Guide 162 Table 5.3.2a-d. Strain Gage Unit C2Sxx 


\section{INTRODUCTION}

In 1981 the Waste Isolation Pilot Plant (WIPP) Project, under the direction of the U.S. Department of Energy (DOE), began construction of a facility in southeastern New Mexico for developing the technology for disposing of radioactive waste from U.S. defense programs. This facility may eventually become a repository for defense transuranic (TRU) wastes, provided that the facility is demonstrated to be acceptable. Although the complete facility includes both surface and underground construction, the Repository Isolation Systems Department under the auspices of the WIPP Project Management Department at Sandia National Laboratories (SNL) is primarily concerned with development of the underground portion of the facility; we focus on that portion of the facility in this report.

Underground construction was divided into three phases: (1) the Site and Preliminary Design Validation phase, requiring the construction of two shafts and shaft stations, a limited entry system, the Transuranic Test Panel, and an exploratory drift (South Drift) to the southern extremity of the facility; (2) the Experimental Area, requiring the construction and fielding of several large research and development (R\&D) Technology Development Program test rooms and the expansion of the shaft system; and (3) the TRU Waste Storage Area, requiring construction of the waste disposal panels for storage of radioactive contact-handled ( $\mathrm{CH}$ ) and remote-handled $(\mathrm{RH})$ waste. The first two of the construction phases are complete; data are currently being acquired for facility design validation and for technology development. For the third phase, after completion of the first storage panel, construction is now stopped, until compliance with the Environmental Protection Agency (EPA) regulations has been demonstrated. Compliance demonstration is required before receipt of TRU 
waste. It is important to note that, although some of the experiments have been completed and decommissioned, the Experimental Area is still operational and the technology development activities continue for TRU waste. The testing activities are now being phased out for defense high level waste (DHLW). Although the DHLW tests initially addressed the disposal of this waste in a bedded salt environment, DHLW is currently slated for disposal in a commercial repository in volcanic tuff.

The experimental activities conducted in the underground facility are the responsibility of SNL. These in situ activities consist of several very large-scale tests and many small-scale experiments to address high priority, important compliance and technology development issues directly through the Repository Isolation Systems, Disposal Room Systems, and Geohydrology Programs. The WIPP in situ testing addresses specifically the disposal of wastes generated from current and past defense programs. These tests, initially defined in a detailed planning document [1], were carried forward by individual test plans defining the implementation and fielding activities for each specific test. As might be expected, a number of supplemental tests not addressed in the initial planning document have been proposed and fielded in the facility. The technology issues address the disposal of TRU $\mathrm{CH}$ and $\mathrm{RH}$ wastes, which are directly relevant to the proposed disposal of TRU wastes at the WIPP. Those test results which initially addressed the disposal of DHLW will now contribute to the validation of the TRU disposal technology. The research currently in progress and the research planned within the Experimental Area will continue to provide data of considerable quantity and high quality.

This report is specific to the Thermal structural Interactions (TSI) in situ tests of the Experimental Area. Within the initial TSI tests are 
six major tests which involve five rooms or room complexes: (1) the 18 $\mathrm{W} / \mathrm{m}^{2}$ Mockup for Defense High-Leve1 Waste (DHLW) in Rooms $\mathrm{A} 1, \mathrm{~A} 2$, and $\mathrm{A} 3$; (2) the Overtest for Simulated Defense High-Level Waste (DHLW) in Room B; (3) the Geomechanical Evaluation Test in Room G; (4) the Heated Axisymmetric Pillar Test in Room $\mathrm{H}$; (5) the In Situ Stress Field (Hydrofrac) Test in Room G; and (6) the Clay Seam Shear Test. The Clay Seam Shear Test is not yet fielded. In situ data are also being obtained from Room $D$, an early excavation for facility ventilation. Since several significant documents have discussed the planning, implementation, and fielding of these TSI in situ tests [2-4], the reader is referred to the original documents for more detailed information.

As the initial test program evolved, it was determined that the technology for prediction of room closure was underpredicting the measured in situ closures by nearly a factor of three [5]. A potential cause of the discrepancy, as suggested by the WIPP Panel of the National Academy of Sciences, was the possible influence of "scale" effects on the creep response of salt. At the time, it was thought the large in situ volumes exhibited a reduction of mechanical strength properties, in a manner similar to hard rocks. If salt exhibited such an effect, a smaller opening than those of the rooms would close at a rate considerably slower than the rooms. As a consequence, the Intermediate Scale Borehole Test was proposed and planned. The size of the excavation of the test is about a factor of 10 smaller than the rooms. Even though further analysis of the basic technology suggested that the discrepancy was the result of an inadequacy of the constitutive model and the details of the simulation, which was subsequently shown to be the case [6], the Intermediate Scale Borehole test was fielded to provide confirmatory in situ data. In 
addition, this unique test was planned to provide a significant test of the SNL three-dimensional code simulation capability. Furthermore, the fact that the salt location could be instrumented prior to the excavation of the borehole gave an opportunity to measure stress changes during excavation; an opportunity not possible with the design and configuration of the earlier in situ tests. Stress changes are more tractable in analysis than the smoothly varying stresses obtained in earlier tests because the relative conditions prior to the stress change can be established, whereas the initial conditions of the earlier tests cannot. In fact, significant steps in the analysis of this test have already been completed using very large, numerical simulations with a three-dimensional code. In these simulations, the entire history of the test was calculated beginning with the excavation of Rooms $\mathrm{C} 1$ and $\mathrm{C} 2$, tracing the changes in stress and displacement of the pillar in the intervening 6.7 years, duplicating the drilling of the intermediate scale borehole, and finally capturing stress changes in the pillar and the borehole response for an additional 2 years. The time span of the simulations was 8.7 years. The initial pretest analysis used a simple steady state model of salt creep with a reduced modulus [7], and the results in this case overpredicted the hole closures subsequently measured in the test. Since then, a more accurate constitutive model incorporating both steady state and transient creep has been used in the simulation of the test; these results are considerably more accurate predictions of the borehole closures [8].

The Intermediate Scale Borehole Test is one of several supplemental tests defined to augment or support the initial TSI test series, and will be reported in the same style as the earlier tests. This report presents the data for the Intermediate Scale Borehole Test fielded in the salt 
pillar between Rooms $\mathrm{C} 1$ and $\mathrm{C} 2$. It specifically focuses on mechanical response data acquired from this test from the initial excavation of the Room C1 and C2 array during March and April 1984, through the intensive data acquisition during the fielding of the intermediate scale test starting January 1989, culminating in the drilling of the borehole in December 1990, and data collection through June 1993, the cut off date for this report. Data, however, continued to be collected after the cut off date. This data report is one of a series intended to document the data obtained from the TSI in situ tests and to make these data available to potential users. Other data reports available include those for the Mining Development Test (Room D) [9], the Heated Axisymmetric Pillar Test (Room H) [10], the Overtest for Simulated Defense High Level Waste (Room B) [11], the $18 \mathrm{~W} / \mathrm{m}^{2}$ Mockup for Defense High Level Waste (Rooms A) $[12,13]$, Geomechanical Evaluation (Room G) [14], and the multipass mining sequence closure data for all the test rooms and shafts, including the intermediate scale test [15]. 


\section{EXPERIMENT DESCRIPTION}

The Intermediate Scale Borehole Test (ISBT) (Rooms C), as detailed in the test plan [16], was designed to investigate the influence of scale effects (i.e., the size of a room) on the creep closure of rooms excavated in the bedded salt deposit in which the WIPP facility is located. Rooms C1 and C2 are located in the Experimental Area at the northeastern corner of the underground facility, as shown in Figure 2.0.1. The test consisted of instrumenting the existing pillar of salt between Rooms $\mathrm{C} 1$ and $\mathrm{C} 2$ and subsequently drilling a $0.9 \mathrm{~m}(3.0 \mathrm{ft})$ diameter horizontal borehole from Room C2 into Room C1 completely through the $18.0 \mathrm{~m}$ (59.0 ft) thick pillar.

The rooms were initially excavated between $3 / 17 / 84$ and $4 / 9 / 84$ for the demonstration of emplacement equipment for high-level waste canisters. However, with the decision to comingle defense and commercial high-level waste, the rooms were no longer needed. Fortunately, the configuration was nearly ideal for the intermediate scale borehole. The large pillar consists primarily of clean halite beds with just three well defined interbeds. The thickness of one of the clean halite beds was sufficient to permit the borehole to have about one radii of salt surrounding it. In addition, the pillar had proven to be quite stable, without spalling of the ribs. Also, because the pillar intersected the $\mathrm{N} 1420$ entry, it was possible to instrument the pillar center with instrument holes from two orthogonal directions. Instrumentation from two directions is especially advantageous for stress meters that measure a single normal component of stress since three orthogonal normal components can be determined. An additional advantage of this location and initial configuration was that a large amount of data and analysis were available from Room $D$, which was at the same horizon, involved the same salt beds, and was of the same cross 


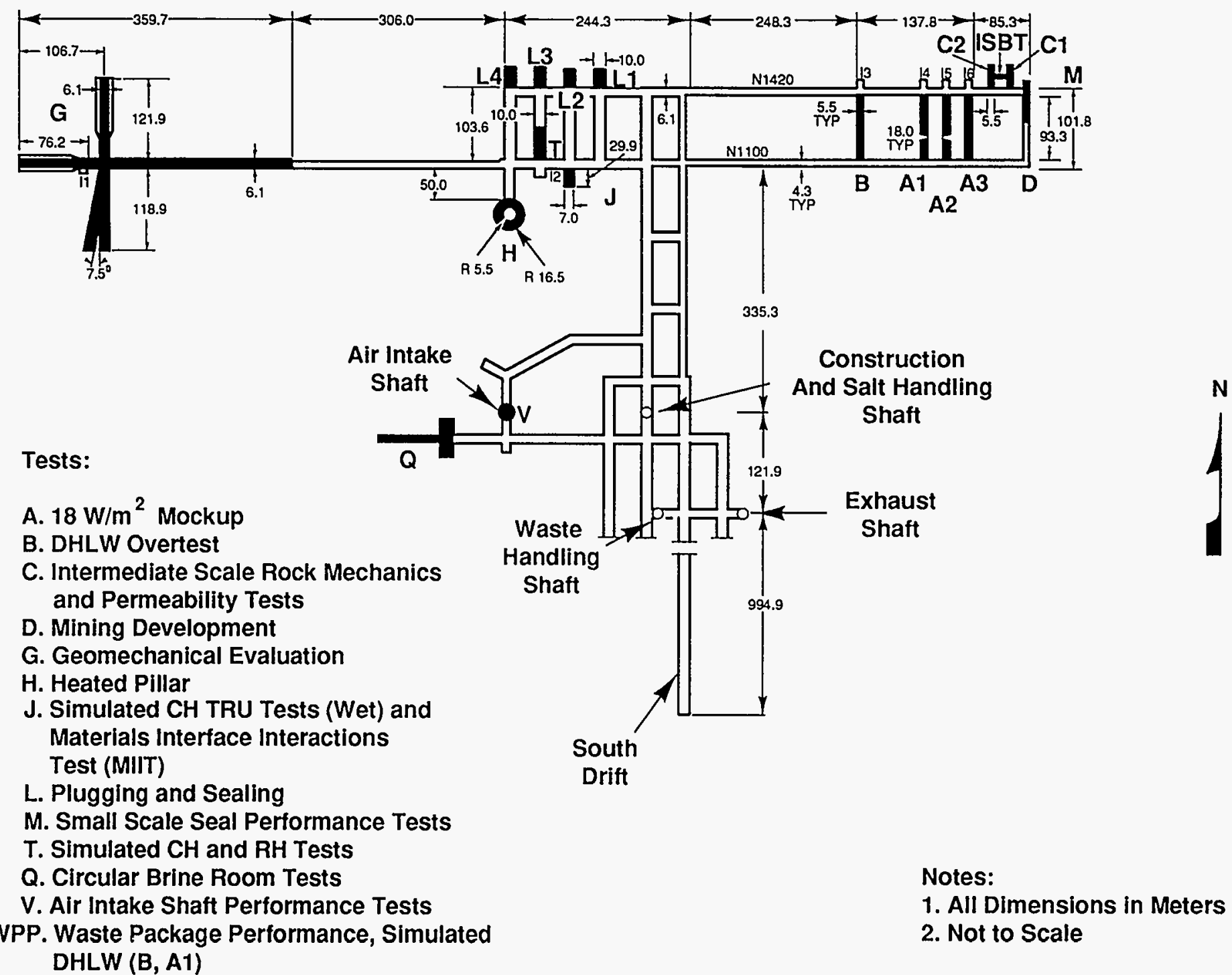


section as the C Rooms. Thus, between $12 / 3 / 90$ and $12 / 13 / 90$, some 6.7 years after the initial excavation of the rooms, the ISBT borehole was cored through the existing pillar.

The fielding of the ISBT test consisted of three distinct phases, which differ slightly from the those phases outlined in the test plan. The first phase involved the drilling of instrument holes and the installation of gages. The instrument holes were grouped into specific gage stations in volumes of salt adjacent to the planned location of the intermediate scale borehole. These gages were to be installed a year in advance of the drilling of the intermediate scale borehole so as to provide a well established baseline response of the pillar-room system and gages. As fielding progressed, instrument hole drilling and gage installation actually took place over a significant time period, with some gages installed only a few months in advance of the borehole drilling.

The second phase, the actual drilling of the intermediate scale borehole, was itself comprised of two steps. First, a small, $45.6 \mathrm{~mm}$ (1.875 in.) diameter pilot hole was drilled completely through the pillar along the intended axis of the intermediate scale borehole. This pilot hole was instrumented with closure strain gages. Second, the $0.90 \mathrm{~m}(3.0$ ft) diameter intermediate scale borehole was then core drilled from Room C2 through the pillar into Room $\mathrm{Cl}$ using the pilot hole to center the core bit. As the coring progressed, mining sequence closure stations were established immediately at the face of the drill hole.

The third phase was continued collection of gage data to determine the new deformation response of the borehole-pillar-room system and gages. Except for failed gages, the acquisition of data continued to the cut-off date of this report, and in fact continued even after that date. During 
drilling of the intermediate scale borehole, often the gage responses indicated a marked change in level, as was initially postulated.

Exact descriptions and special features of the WIPP underground facility will appear in a separate document on construction. A full description of the instruments and gages will also appear in a separate document. Further relevant information is contained in documents on the data acquisition system [17] and on the overall WIPP In situ Data Acquisition, Analysis, and Management (WISDAAM) System [18]. Some limited information from these documents is required for our purposes here. Consequently, in this section we briefly discuss the test configuration, mining, and special features of the Intermediate Scale Borehole Test as background for the experimental data presented in this report.

\subsection{Test Configuration}

2.1.1 Physical: As shown in Figure 2.0.1, Rooms $\mathrm{Cl}$ and $\mathrm{C} 2$ are located off the N1420 entry in the northeast corner of the facility. Rooms $\mathrm{C} 1$ and $\mathrm{C} 2$ are $31.1 \mathrm{~m}(102.0 \mathrm{ft})$ and $29.9 \mathrm{~m}(98.1 \mathrm{ft})$ long, respectively, and are $5.5 \mathrm{~m}$ high by $5.5 \mathrm{~m}$ wide $(18.0 \mathrm{ft}$ by $18.0 \mathrm{ft}$ ). The rooms are separated from each other by an $18.0 \mathrm{~m}(59.0 \mathrm{ft})$ thick pillar. The Rooms $\mathrm{C}$ were constructed to be thermally and mechanically isolated from the other test rooms. These rooms were mined on the north side of

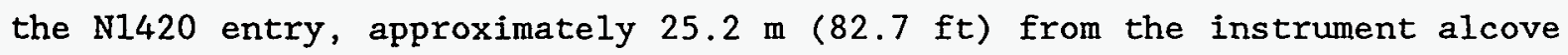
of Room A3 to the west and the alcove $M$ of Room $D$ to the east.

The centerline of the intermediate scale borehole is located at the horizontal midlength of Room C2, approximately $15.2 \mathrm{~m}(50.0 \mathrm{ft}$ ) from the N1420 entry drift. Because the rooms are not quite the same depth, the centerline is not exactly at the midlength of Room $C 1$. A plan view of the configuration is shown in Figure 2.1.1. Vertical center of the borehole 


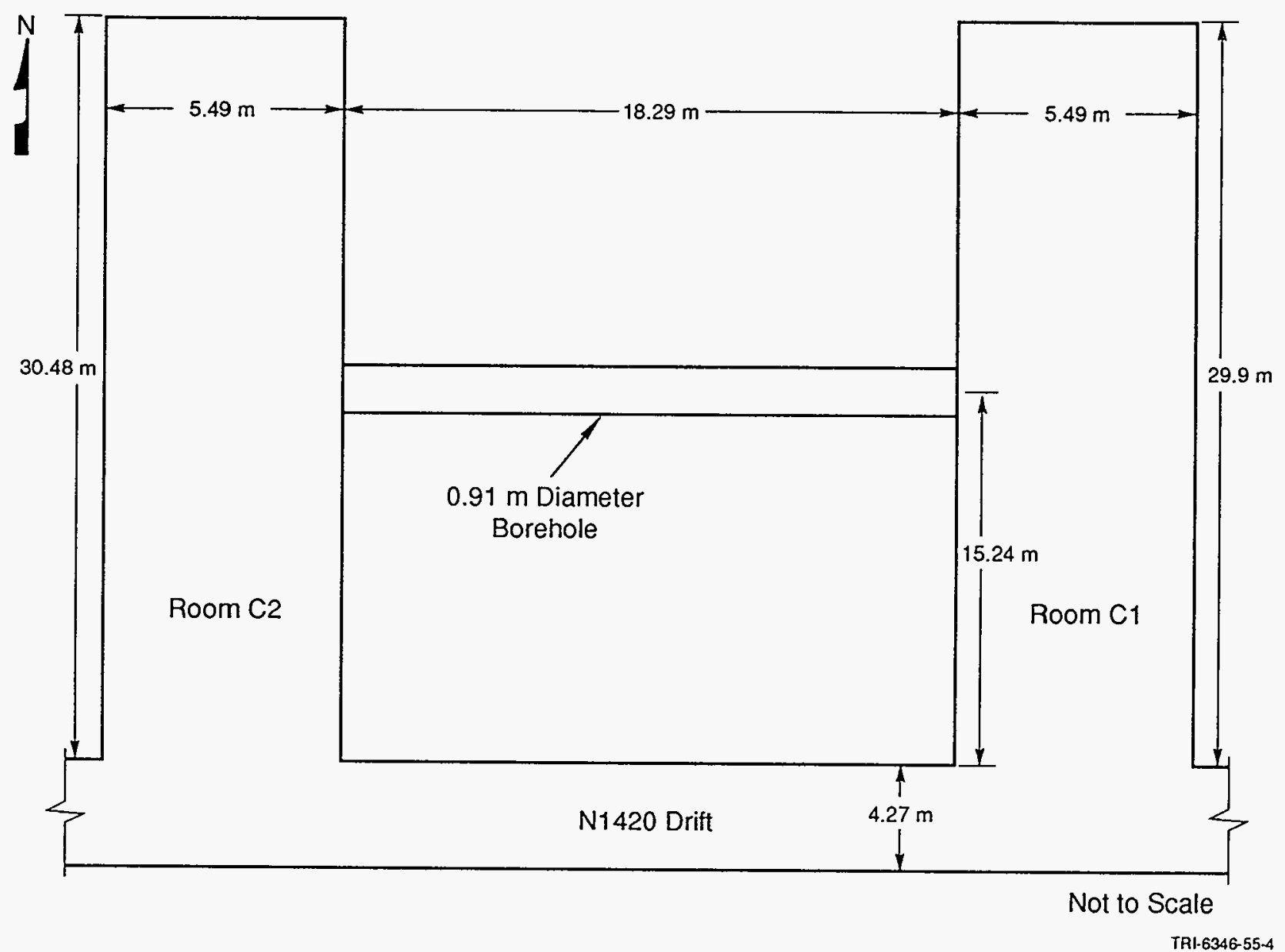

Figure 2.1.1. Plan View of the Intermediate Scale Borehole Test 
is $1.62 \mathrm{~m}(5.30 \mathrm{ft}$ ) above the room floor, in the center of the clear halite bed in the lower half of the room. Figure 2.1.2 and 2.1.3 are elevations showing the location of the borehole center on the pillar face and through the pillar, respectively. To assure the borehole is centered in the thickness of this bed, the hole centerline dips slightly as it goes from Room C2 to Room C1 to accommodate the dip in the stratigraphy.

In contrast to most of the TSI in situ tests fielded previously, the ISBT was not isolated from the surrounding rooms and entries. In the bulk of the initial TSI tests, the design assured that critical portions of the test rooms maintained a two dimensional or planar deformation throughout a critical time interval of the test. By design, the ISBT configuration is essentially three dimensional. This means that within the time frame of the existence of the pillar, it interacts not only with the adjacent rooms but also with the N1420 entry. The introduction of the borehole into this system then will experience nonplanar deformations reflecting the three dimensional nature of the test.

2.1.2 Gages: Instruments in the test consisted of the following:

(1) Temporary, remotely read, vertical and horizontal borehole strain gages installed in the pilot hole.

(2) Temporary, manually read, vertical and horizontal closure gages established concurrently with excavation of the intermediate scale borehole (these are "mining sequence" gages).

(3) Permanent, remotely read, closure gages situated on the rib (wal1) of Room C2 surrounding the opening of the intermediate scale borehole.

(4) Permanent, remotely read, vertical and horizontal closure gages in the intermediate scale borehole. 


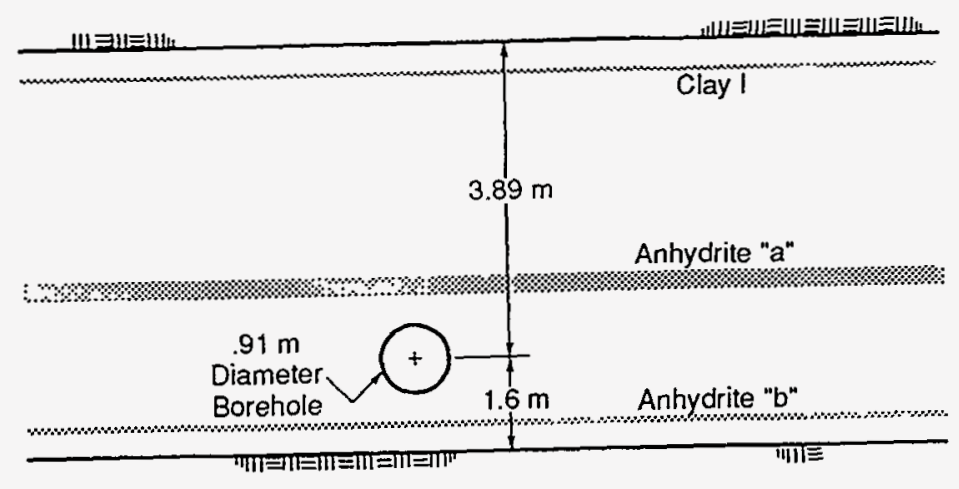

Borehole Endview

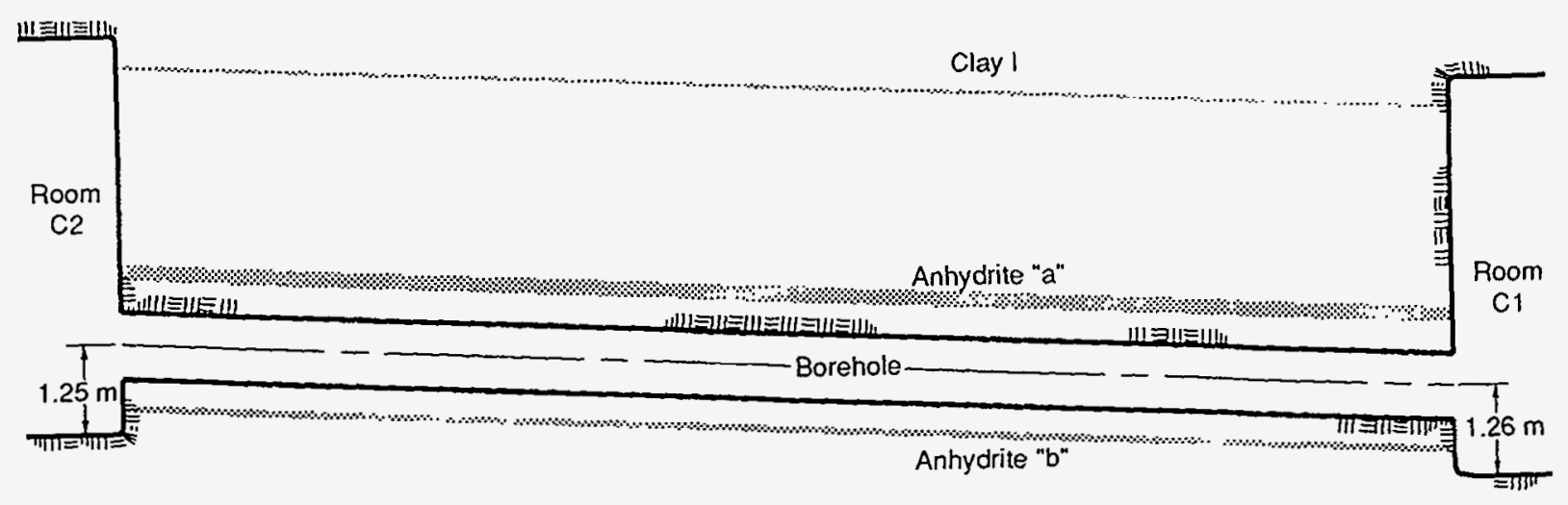

Borehole Profile

T/C-13160.1

Figure 2.1.2. Cross Section Elevations of "As Built" Test 
(5) Permanent, remotely read, extensometers specifically designed to measure radial displacement with collars in the N1420 drift and anchor points fixed at locations around the intermediate scale borehole and concentrated at specific gage stations.

(6) Permanent, remotely read, stress meters that are emplaced in boreholes from $1.5 \mathrm{~m}$ to $9.8 \mathrm{~m}(5.0 \mathrm{ft}$ to $32.0 \mathrm{ft}$ ) in length and drilled from Rooms $\mathrm{C} 1$ and $\mathrm{C} 2$ parallel to the trend of the intermediate scale borehole to form the various stations in the material around the borehole.

(7) Permanent, remotely read, stress meters installed in boreholes from $12.8 \mathrm{~m}$ to $17.4 \mathrm{~m}(42.0 \mathrm{ft}$ to $57.0 \mathrm{ft})$ in length that originate from the N1420 drift and are drilled perpendicular to the trend of the intermediate scale borehole to intersect various stations in the material around the borehole.

Well before any drill operations involving the intermediate scale borehole occurred, the permanent extensometer and stress meter gages were installed. Essentially these gages were installed immediately after the drilling of the instrument boreholes was completed. Also, one set of the permanent closure gages was installed on the rib of Room $\mathrm{C} 2$ before the drilling of the pilot hole. The temporary borehole strain gages were installed in the pilot hole prior to drilling of the intermediate scale borehole. Mining sequence gages were installed and read throughout the drilling process of the intermediate scale borehole (the data from these gages will be repeated here, even though they were originally presented in a special report [15]). The remaining closure gages were installed in the intermediate scale borehole after the borehole had been completed.

The gages described above can be classified according to gage type and 
manufacturer. Most of the gages were devoted to either displacement or closure measurements, which, along with the stress measurements, were considered to be the highest priorities in the experiment. The strain gages which were to provide supplemental information, consisted of only 4.28 of the gages in the Intermediate Scale Borehole Test complex. The four gage types that are presented in this report are as follows:

(1) Closures, Research, Inc. (R.I.), constant torque, spring-motor driven, linear-potentiometer, remotely-read, stainless-steel cable (wire) installation.

(2) Extensometers, Serata E-200 (an SNL modification) constant torque, spring-motor driven, 5 point anchor, linearpotentiometer, stainless-steel cable (wire) units.

(3) Stress meters, either (a) SNL Strain-Gaged Stress meters (SGS) that are remotely read two-gage arrays emplaced in an orthogonal pattern, or (b) U.S. Bureau of Mines (BuMines) Cylindrical and Borehole Pressure Cells (CPC and BPC) in arrays of one CPC and two orthogonal BPCs, with remotely read Kulite pressure transducers.

(4) Strain gages, SNL developed, Micro Measurements, CEA-06125UN-350, four active arm strain gage mounted on cantilever beams.

Table 2.1.1 is a summary of the quantities of each of the gage types that were installed in the Intermediate Scale Borehole Test.

Each gage has a unique designation code. Gage designations (numbers) were configured to convey important information about the gage. The gage designation code is a set of 7 alphanumeric characters (for example, C2M01-1) which contains several useful pieces of information. The first 
Table 2.1.1. Gage Summary

\section{INSTRUMENT UNITS}

DRILLING

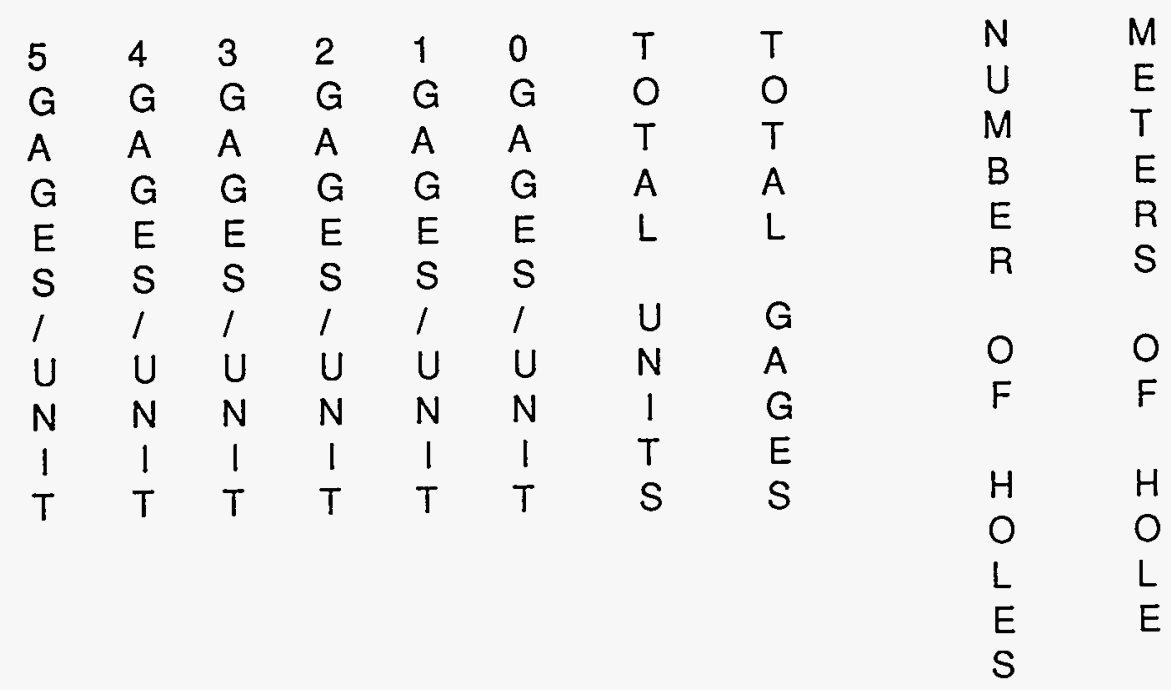

\begin{tabular}{|c|c|c|c|c|c|c|c|c|c|c|}
\hline $\begin{array}{c}\text { Extensometer } \\
\text { Serata }\end{array}$ & 12 & - & - & - & - & - & 12 & 60 & 12 & 205 \\
\hline \multicolumn{11}{|l|}{ Closure } \\
\hline \multicolumn{11}{|l|}{ Manual } \\
\hline Mining Sequence & - & - & - & - & 14 & - & 14 & 14 & 0 & 0 \\
\hline \multicolumn{11}{|l|}{ Remote } \\
\hline R.I. & - & - & - & - & 4 & - & 4 & 4 & 0 & 0 \\
\hline R.I. (in hole) & - & - & - & - & 14 & - & 14 & 14 & 0 & 0 \\
\hline \multicolumn{11}{|l|}{ Stress Meters } \\
\hline Bumines & - & - & 15 & - & - & - & 15 & 45 & 15 & 194 \\
\hline S.G.S & - & - & - & 30 & - & - & 30 & 60 & 30 & 357 \\
\hline \multicolumn{11}{|l|}{ Premining Gages } \\
\hline Strain & - & - & - & 4 & - & - & 4 & 8 & 1 & 18 \\
\hline Total & 12 & - & 15 & 34 & 32 & - & 93 & 205 & 58 & 774 \\
\hline
\end{tabular}


character is a letter representing the specific test room (in this example, "C"). The next character field indicates the room from which the unit (gage) was installed ("1" for Room C1, "2" for Room C2, and if blank or "-" the N1420 drift). The unit (gage) type is given by the first of the next 3 numeric characters: " $1 \mathrm{xx}^{\prime}$ and " $2 \mathrm{xx}^{\prime}$ are closure, " $3 \mathrm{xx}$ " and $" 4 \mathrm{xx}^{\prime}$ are extensometers, and " $5 \mathrm{xx}^{\prime}$ and " $6 \mathrm{xx} "$ are stress meter units. Here a unit is a collection of gages that are assembled and belong together. Special gage types that were added after completion of the test plan have a gage type with an initial alphabetic character keyed to the type of gage. In the Intermediate Scale Borehole Test, "Mxx" are mining sequence closure gages, and "Sxx" are strain gages. The sixth alphanumeric character is the subunit designation. In the Intermediate Scale Borehole Test we encounter only one type of subunit indicated with a "-" which tells us that the gages of the subunit are all contained in the same borehole. Finally, the last numeric character is the specific gage of the unit. Gages of a unit or subunit may range from 0 to 9 . Some units, such as closure types, may have only 1 gage.

The location of each gage is specified, within construction tolerance limits, in terms of an $(X, Y, Z)$ coordinate system. Ideally, the geometric center of the borehole is $\mathrm{X}=0, \mathrm{Y}=0$, and $\mathrm{Z}=0$, where "X" is positive in the east direction, " $Y$ " is positive in the north direction, and " $Z$ " is positive in the vertical (up) direction. In general, the gage location requires pairs of coordinates which specify the two end locations of the gage. For gages set into boreholes, the first coordinate set $(\mathrm{X} 1, \mathrm{Y} 1, \mathrm{Z1})$ defines the collar and the second set $(\mathrm{X} 2, \mathrm{Y} 2, \mathrm{Z} 2)$ defines the point at depth. For a single point gage, the sets are duplicates.

Because of the peculiarities of excavation of the test rooms in a 
slightly dipping geology, two pairs of "Z" values are given. One pair of values is the location in terms of the test room coordinate system; the other pair of values is in terms of the local midheight origin of a principal station (principal stations are discussed in Section 2.3.1).

Gage or unit locations for the gages measuring the response of the in situ material and the borehole are shown in the plan views of Figures 2.1.3a-d. Each plan view is a plane at a different vertical elevation. The plan views show the concentration of gages at the principal stations of the test. Elevation cross section views of the principal stations along the drill hole axis are given in Figures 2.1.4a-f. Additional elevations through the pillar of the instrument locations are given in Figures 2.1.5a-b.

\subsection{Construction}

For this report, the specific activities for construction of the borehole are described in detail; however, those activities pertaining to the construction of the pillar and rooms are summarized in abbreviated form. Only data relevant to the temporary and remote permanent gages are noted; procedures and data for the mining sequence gages are discussed. Construction activities are divided into mining, instrumentation, and operation. Full construction details of the rooms are contained in a separate document.

2.2.1 Mining and Geology: The two $C$ Rooms, although not a part of the initial TSI program, were excavated at the time of the mining of the N1420 entry as part of the operational demonstration for large canister emplacement equipment. At that time Ohbayashi-Gumi, a mining contractor, made the excavations by continuous mining machine. The details of these excavations are of little importance except [text continues on page 30] 


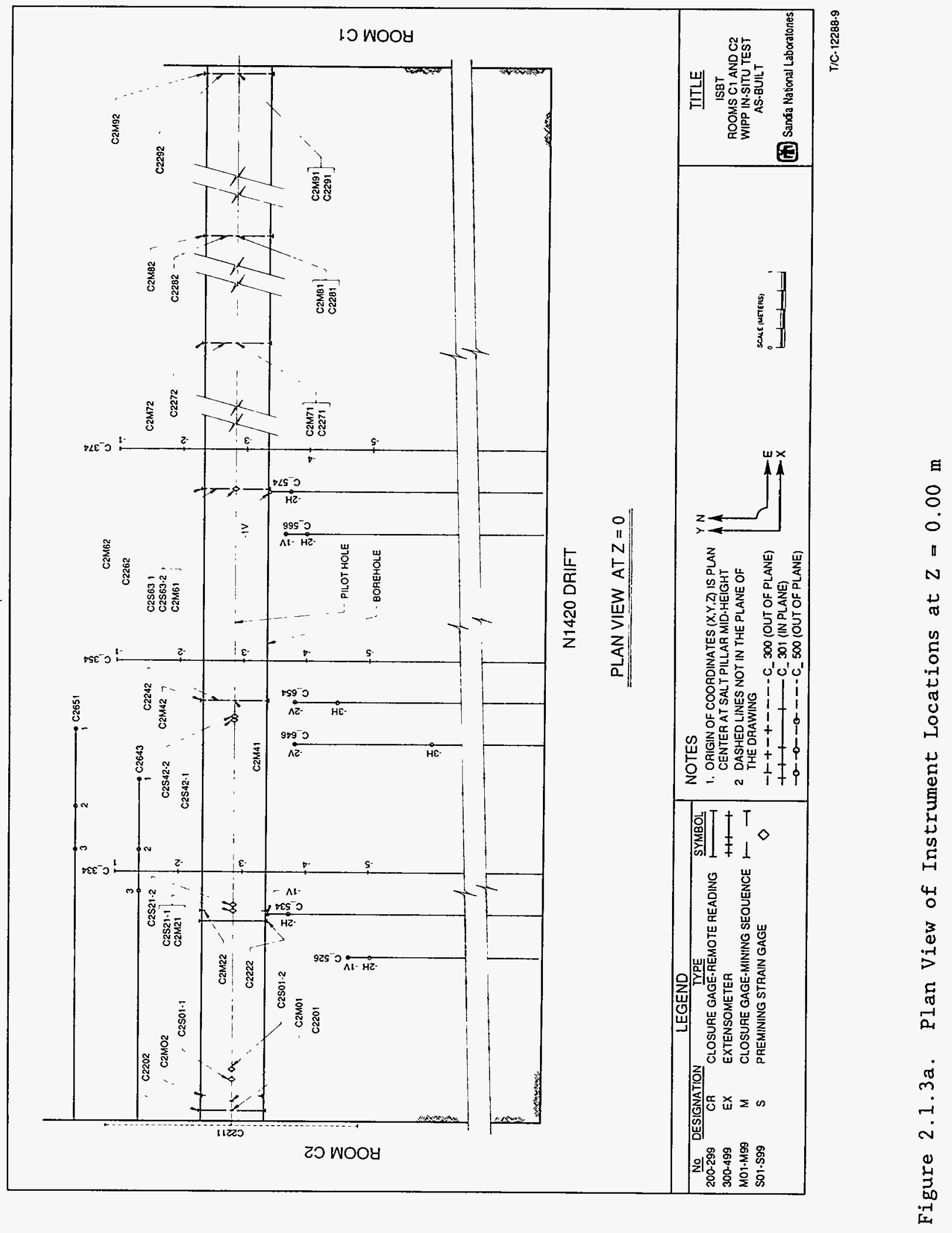




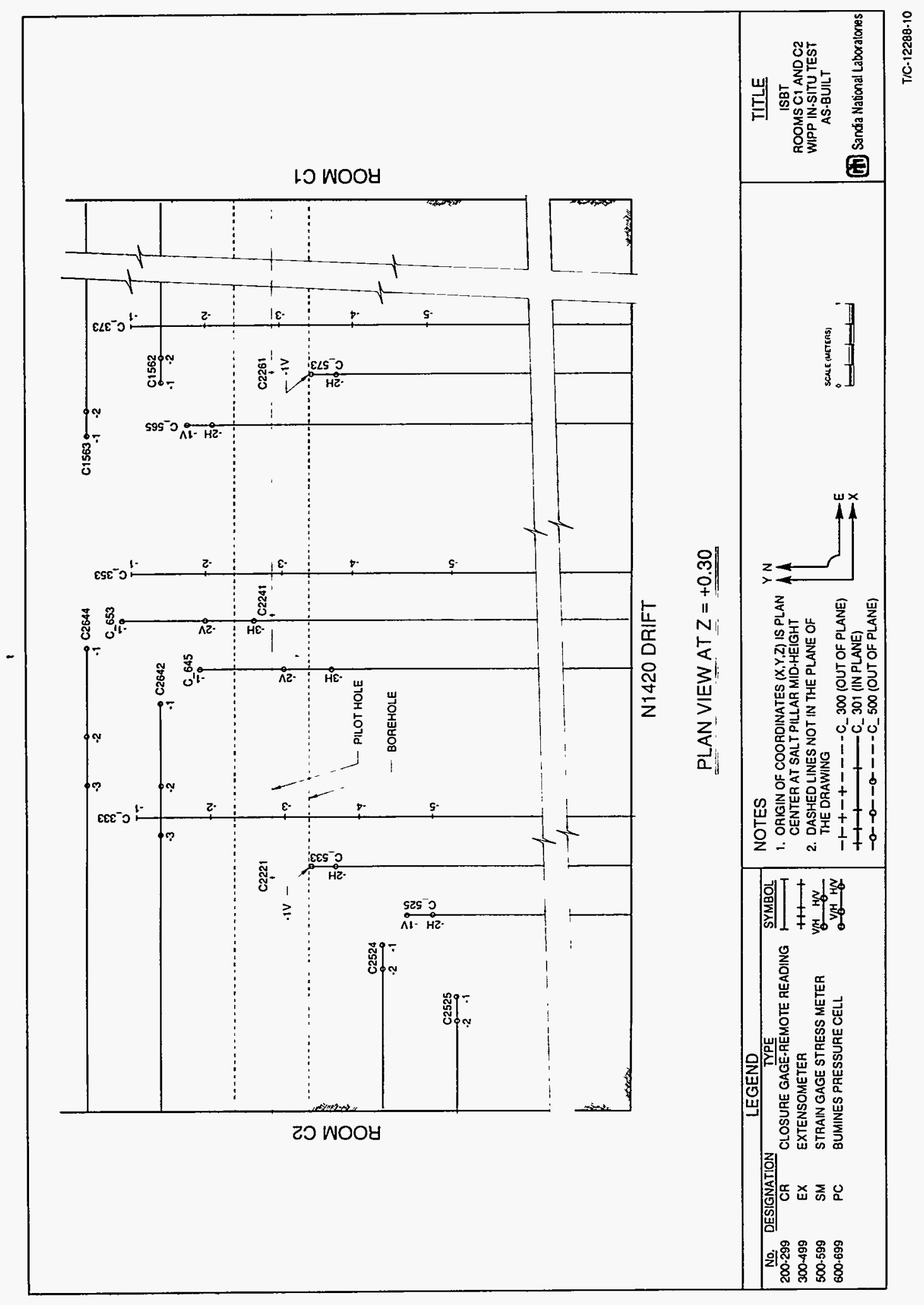

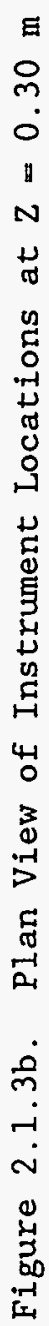




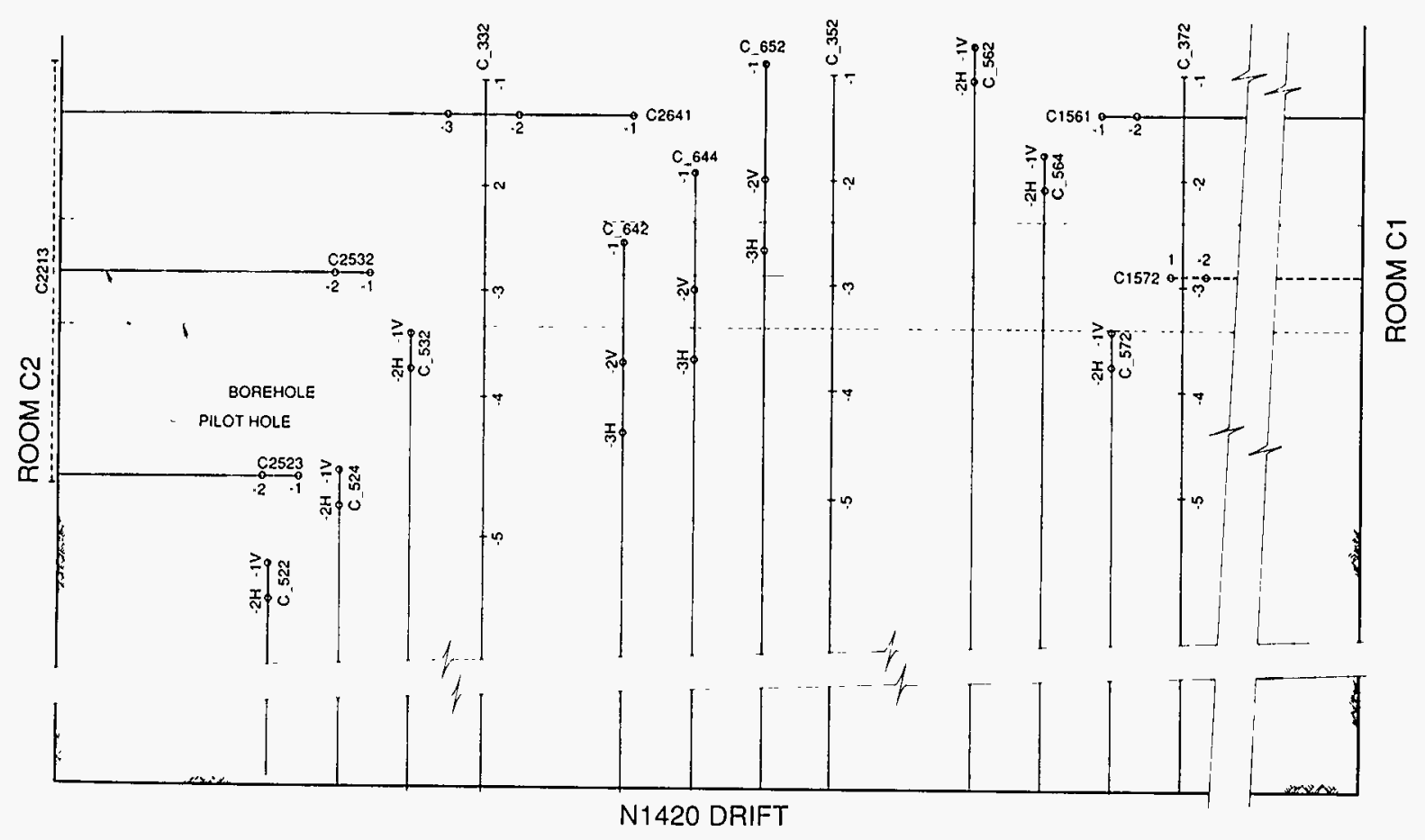

PLAN VIEW AT $Z=+1.22$

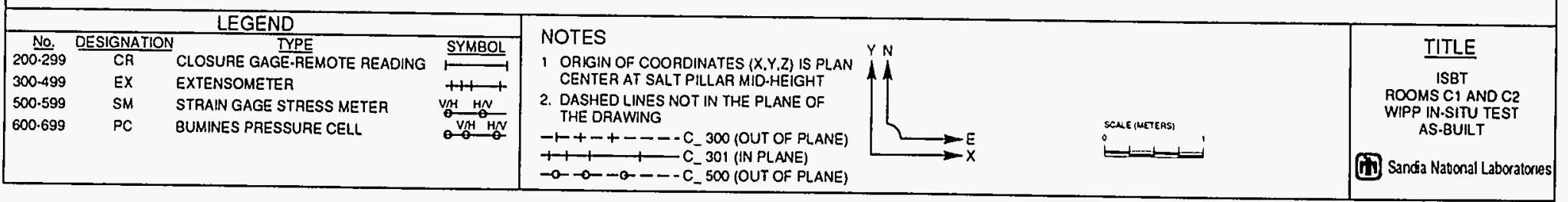

TIC.12288.11

Figure 2.1.3c. Plan View of Instrument Locations at $Z=1.22 \mathrm{~m}$ 


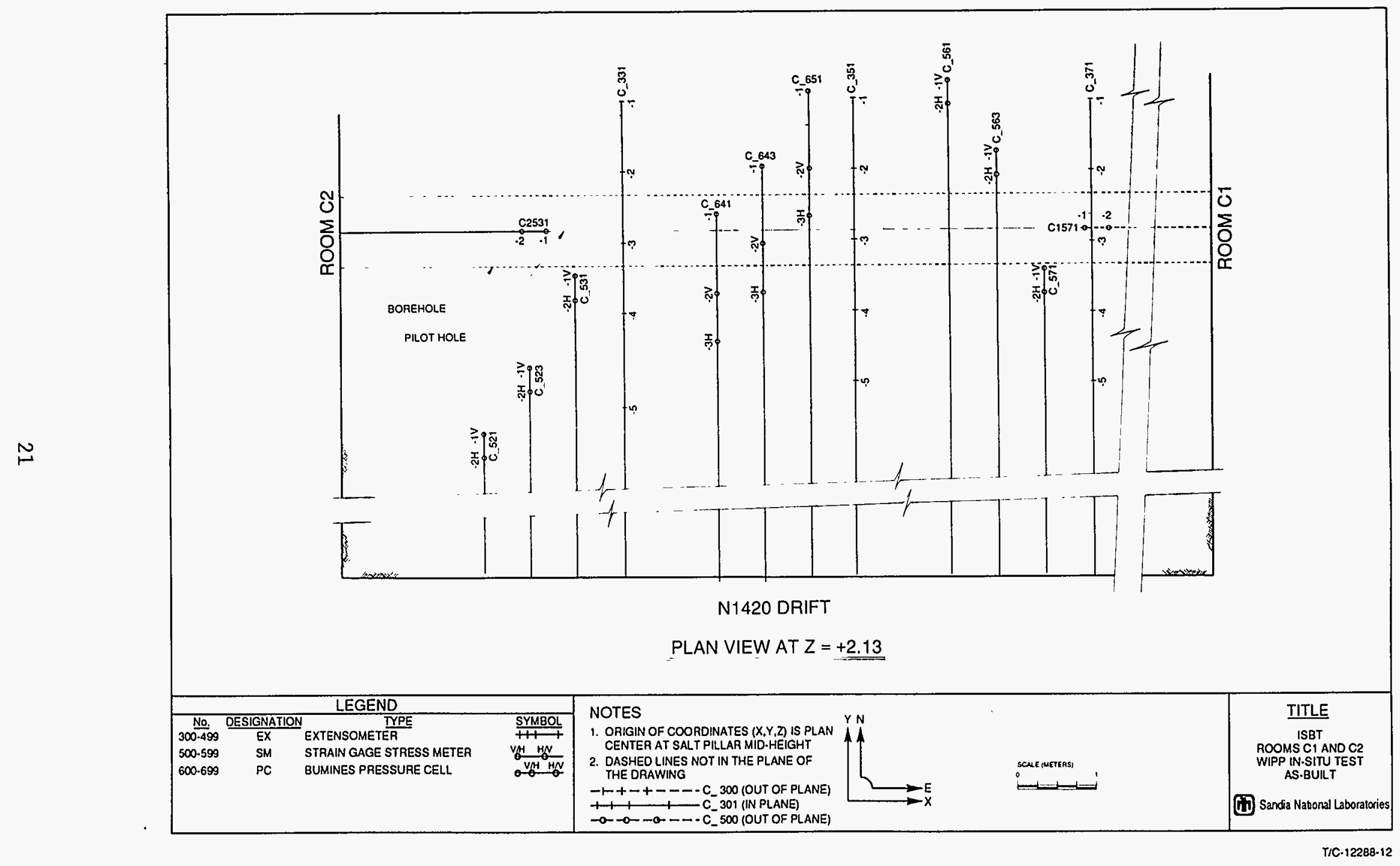

Figure 2.1.3d. Plan View of Instrument Locations at $Z=2.13 \mathrm{~m}$ 


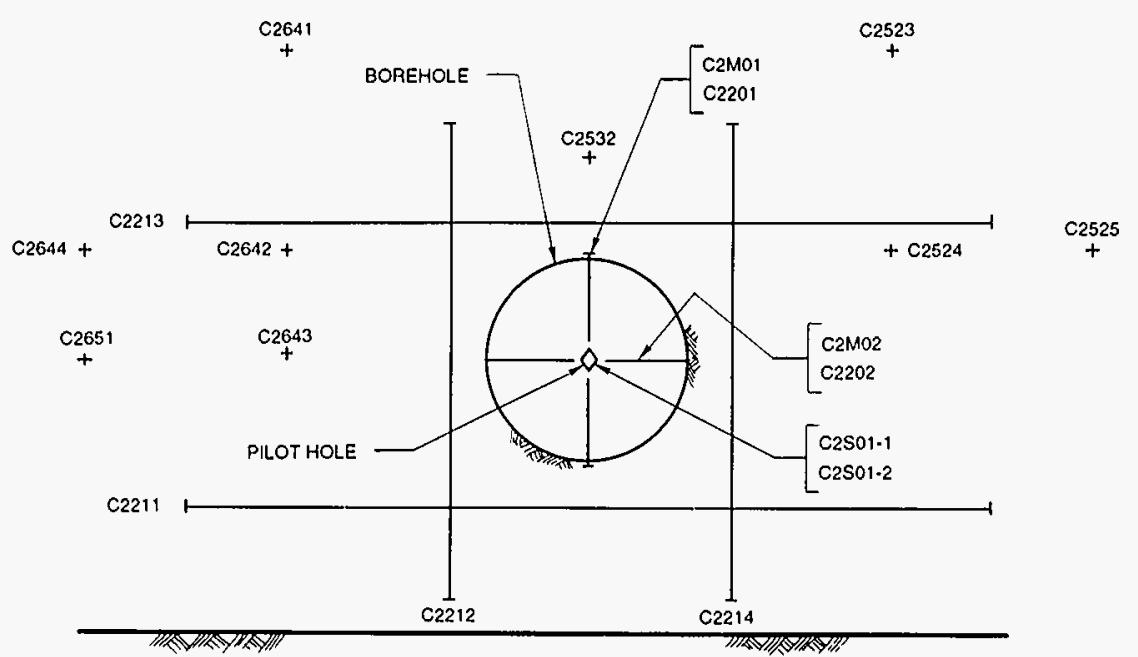

\section{ELEVATION VIEW LOOKING EAST \\ FROM ROOM C2 RIB \\ AT $X=-9.2$}

\begin{tabular}{|c|c|c|c|c|c|c|}
\hline \multicolumn{3}{|r|}{ LEGEND } & & \multirow{5}{*}{ i } & \multirow{6}{*}{$\begin{array}{l}\text { SCALE (METERS) } \\
0 \\
0\end{array}$} & \multirow{6}{*}{$\begin{array}{l}\frac{\text { TITLE }}{\text { ISBT }} \\
\text { ROOMSC1 AND C2 } \\
\text { WIPP IN.SITUTEST } \\
\text { AS.BUILT } \\
\text { (14) Sanda Natonal Laboratones }\end{array}$} \\
\hline$\frac{\text { No. }}{200.299}$ & $\frac{\text { DESIGNATION }}{\text { CR }}$ & CLOSURE GAGE.REMOTE READING SYMBOL & $\begin{array}{l}\text { NOTES } \\
\text { I ORIGIN OF COOROINATES }(X Y Z) \text { IS PLAN }\end{array}$ & & & \\
\hline $500-599$ & SM & $\begin{array}{l}\text { STRAIN GAGE STRESS METER } \\
\text { VH HN }\end{array}$ & $\begin{array}{l}\text { CENTER AT SALT PILLAR MID.HEIGHT } \\
\text { SIIV }\end{array}$ & & & \\
\hline 600.699 & PC & BUMINES PRESSURE CELL & $\begin{array}{l}\text { 2. DASHED LINES NOT IN THE PLANE OF } \\
\text { THE DRAWING }\end{array}$ & & & \\
\hline M01-M9S & M & CLOSURE GAGE-MINING SEOUENCE $\vdash-$ & $-\leftarrow+-+----C 300$ (OUT OF PLANE) & & & \\
\hline S01-S99 & $\mathbf{s}$ & PREMINING STRAIN GAGE & $\begin{array}{l}+1, c_{-} 301 \text { (IN PLANE) } \\
-0-0-0--c_{-} 500 \text { (OUT OF PLANE) }\end{array}$ & & & \\
\hline
\end{tabular}

Figure 2.1.4a. Elevation of Instrument Locations at Principal Station $X=-9 \mathrm{~m}$ 


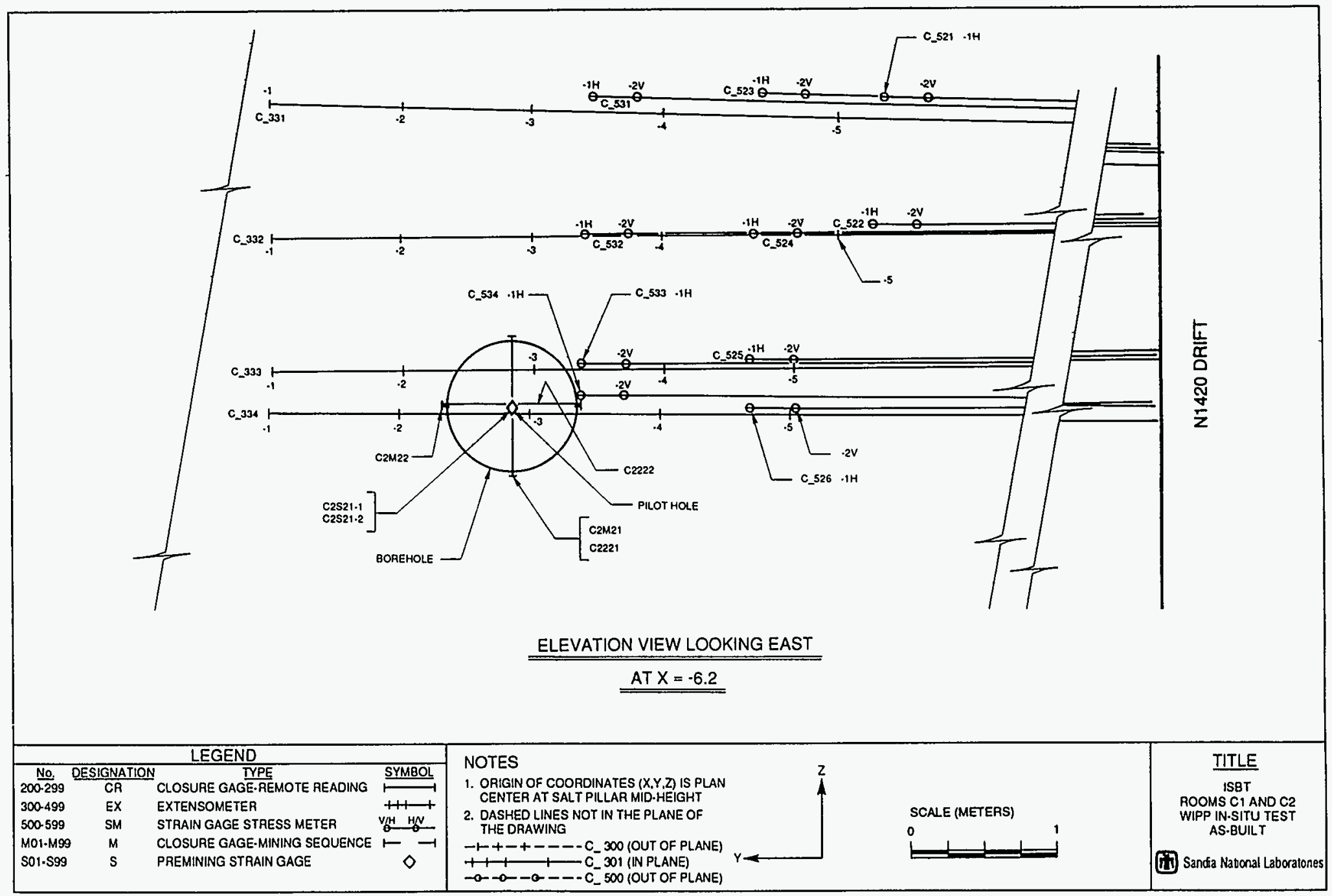

T/C.12288-4

Figure 2.1.4b. Elevation of Instrument Locations at Principal Station $X=-6 \mathrm{~m}$ 


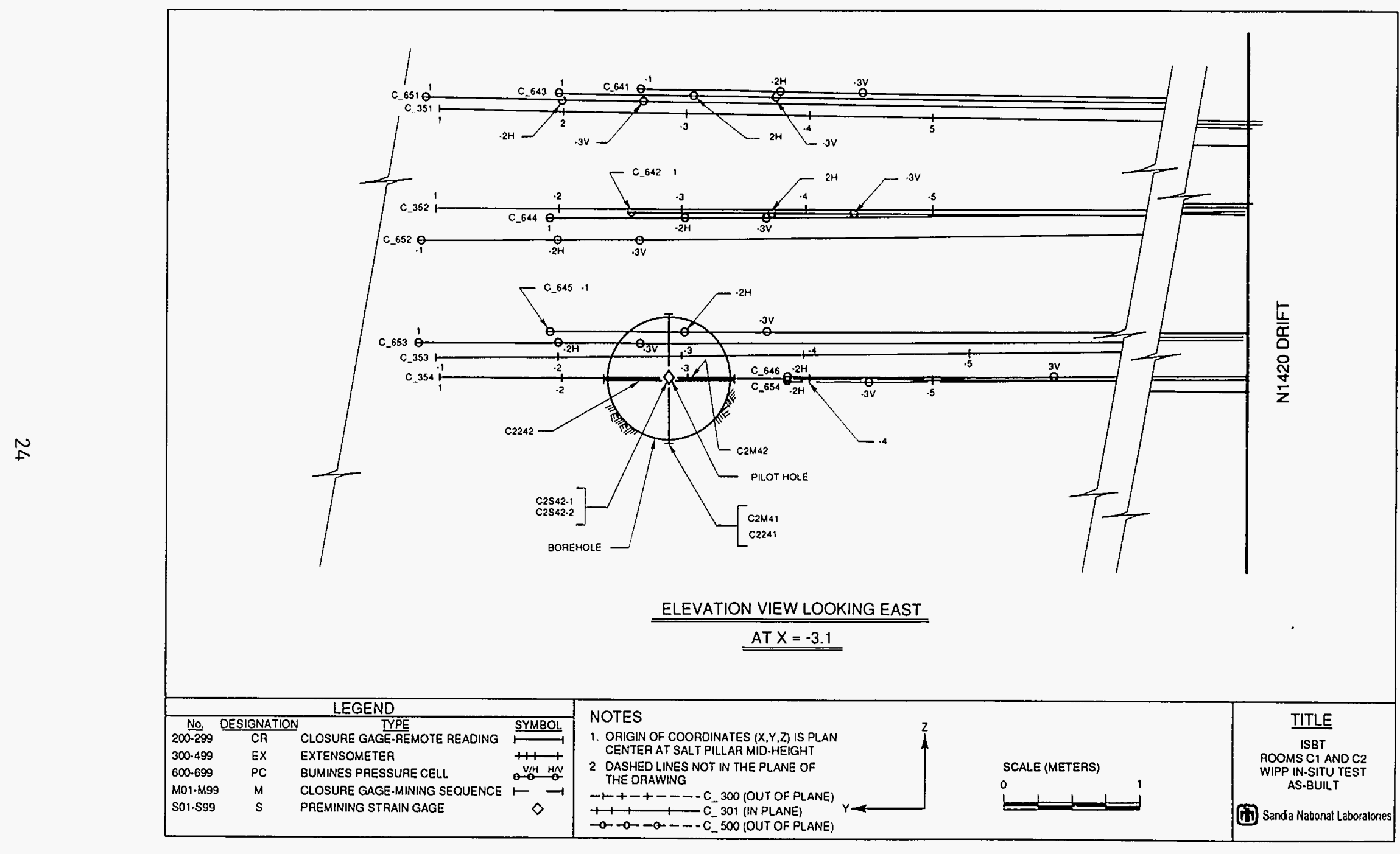

T/C-12288-5

Figure 2.1.4c. Elevation of Instrument Locations at Principal Station $X=-3 \mathrm{~m}$ 


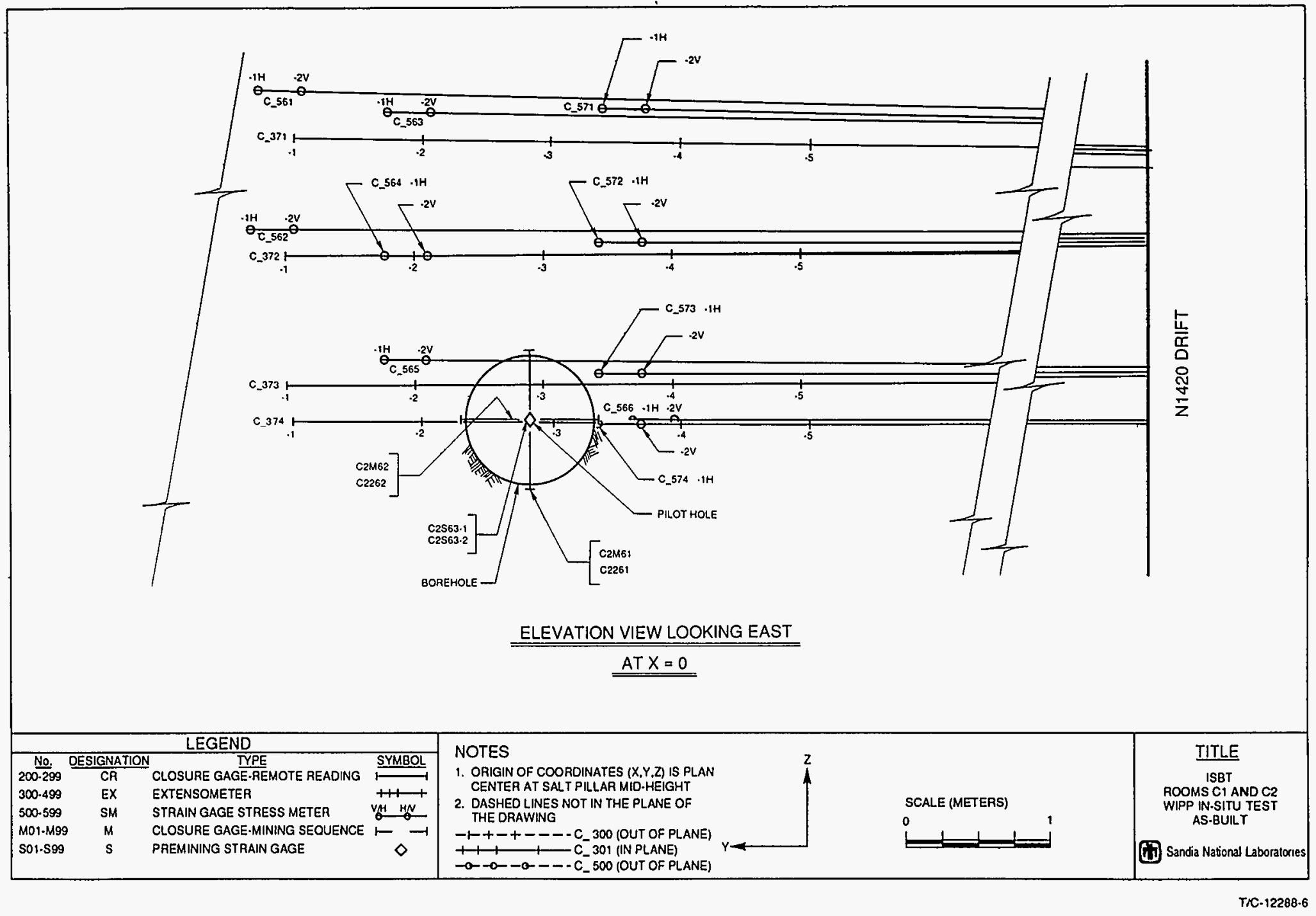

Figure 2.1.4d. Elevation of Instrument Locations at Principal Station $\mathrm{X}=0 \mathrm{~m}$ 


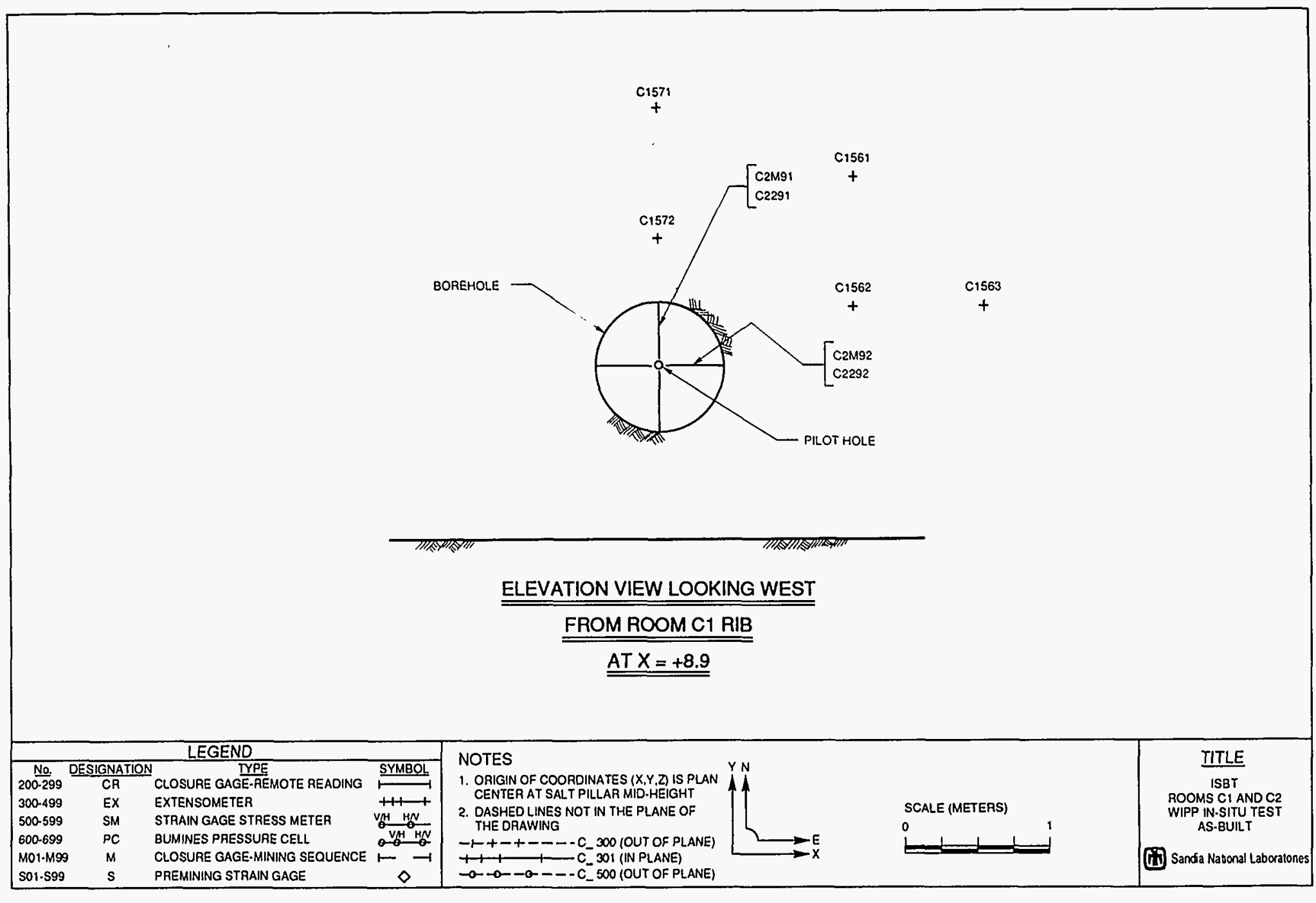

T/C-12288-8

Figure 2.1.4f. Elevation of Instrument Locations at Principal Stations $\mathrm{X}=9 \mathrm{~m}$ 


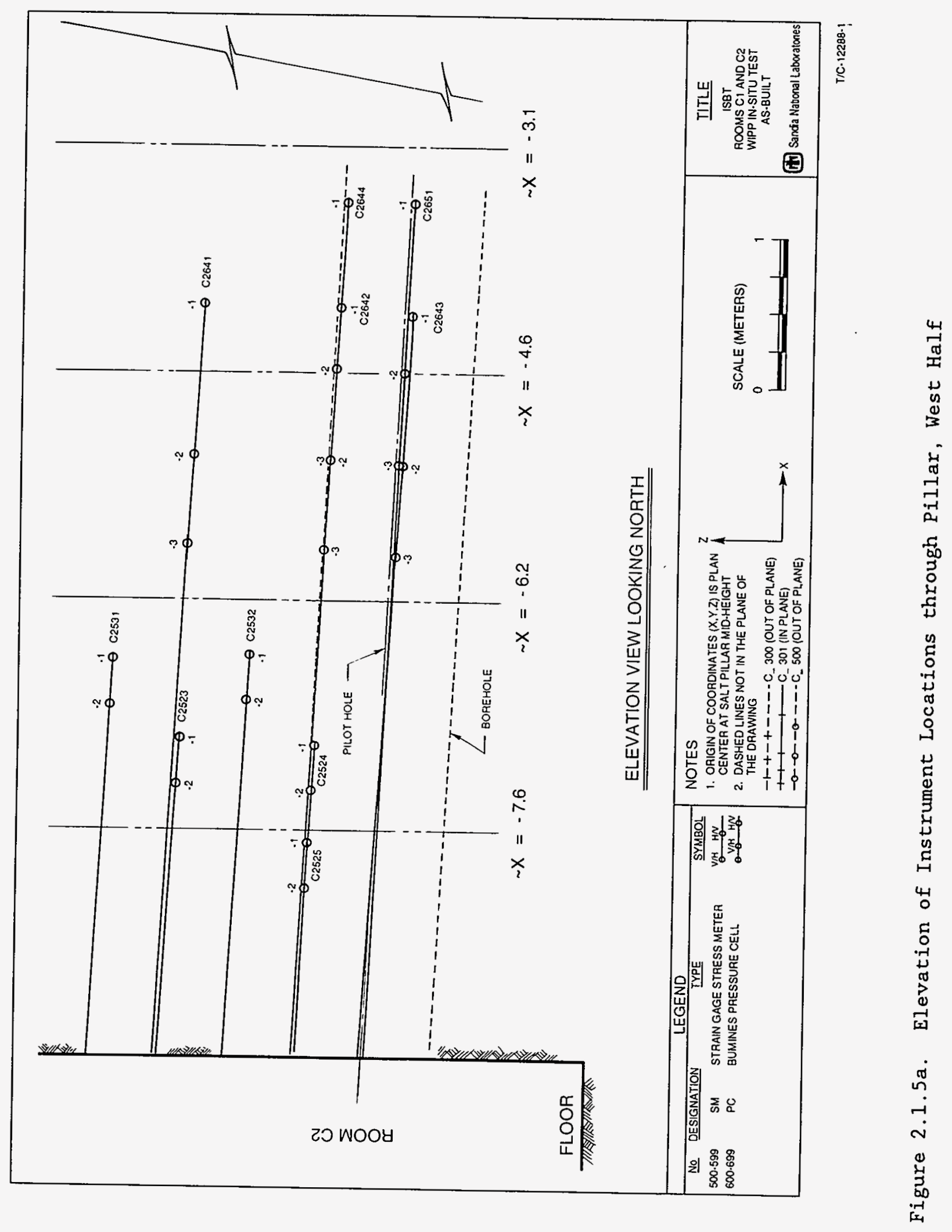




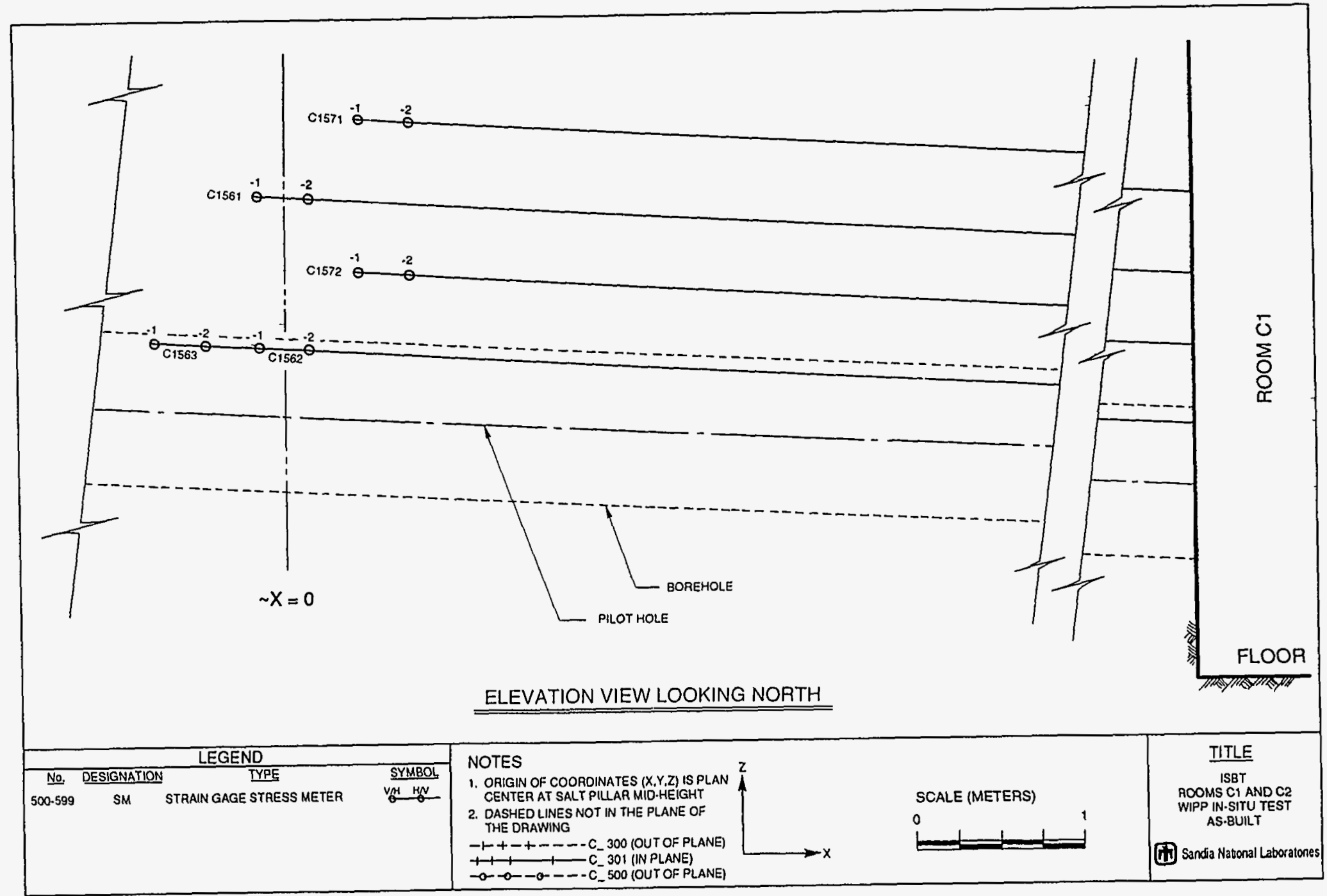

T/C.12288-2

Figure 2.1.5b. Elevation of Instrument Locations through Pillar, East Half 
for the eventual use of the pillar between these rooms as the location of the ISBT. The mining machine in a short conveyor belt mode turned into Room $\mathrm{C} 2$ on $3 / 17 / 84$ and mined a portion of the upper bench, but soon moved on $3 / 28 / 84$ to Room $C 1$ to turn into this room. Then, with the machine changed to the long conveyor belt mode, the entire upper bench and brows in Room C1 were completed. The machine then returned to Room C2 to complete the upper bench and brows in this room. The machine made a full lower pass to remove the bench in Room C2, followed by a similar pass in Room Cl. Both rooms were completed by $4 / 9 / 84$. These rooms both have a $5.5 \mathrm{~m}(18.0 \mathrm{ft})$ by $5.5 \mathrm{~m}(18.0 \mathrm{ft})$ cross section and are $29.9 \mathrm{~m}(98.1 \mathrm{ft})$ and $31.1 \mathrm{~m}(102.0 \mathrm{ft})$ deep for $\mathrm{C} 1$ and $\mathrm{C} 2$, respectively. They are separated by an $18.0 \mathrm{~m}(59.0 \mathrm{ft})$ thick pillar. There are no major excavations to the west, north, or east of the rooms.

These rooms were set into the stratigraphy at the same elevation as TSI tests in Room B, Rooms A, and Room D. Actually, the excavation was such that it just removed the clay seam in the roof, so that the elevation of the room reflected the local dip and variation in the stratigraphic elevation of the clay seam. The pillar between Rooms $C$ was chosen for the ISBT because of the geology. The ribs of Rooms $\mathrm{C} 1$ and $\mathrm{C} 2$ intercept two very important salt layers, separated by the thin anhydrite "a" band, as shown in the local stratigraphic section of Figure 2.2.1. The room coordinate center is at a depth of $638.6+/-0.3 \mathrm{~m}(2095+/-1 \mathrm{ft})$ below the ground surface. Also, the floor of the room is approximately $6.8 \mathrm{~m}$ (22.3 ft) above the Marker Bed 139 anhydrite layer of the ' 84 Reference Stratigraphy as given by Krieg [19]. This ' 84 stratigraphy has now been replaced by the reference stratigraphy proposed by Munson et al. [20], as shown in Figure 2.2.2. 


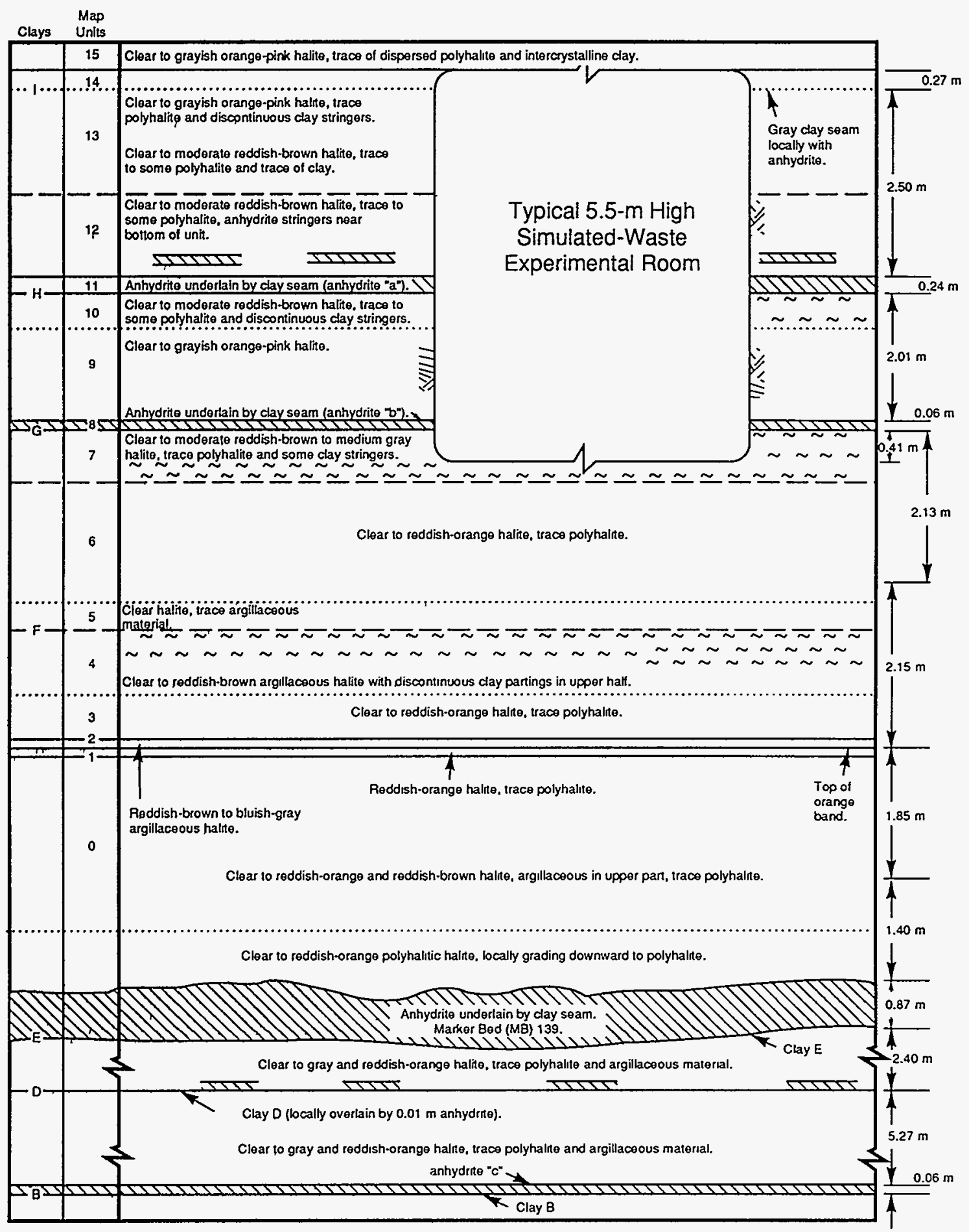

TRI-6334-257-9

Figure 2.2.1. Test Room Elevation with Respect to Stratigraphy 

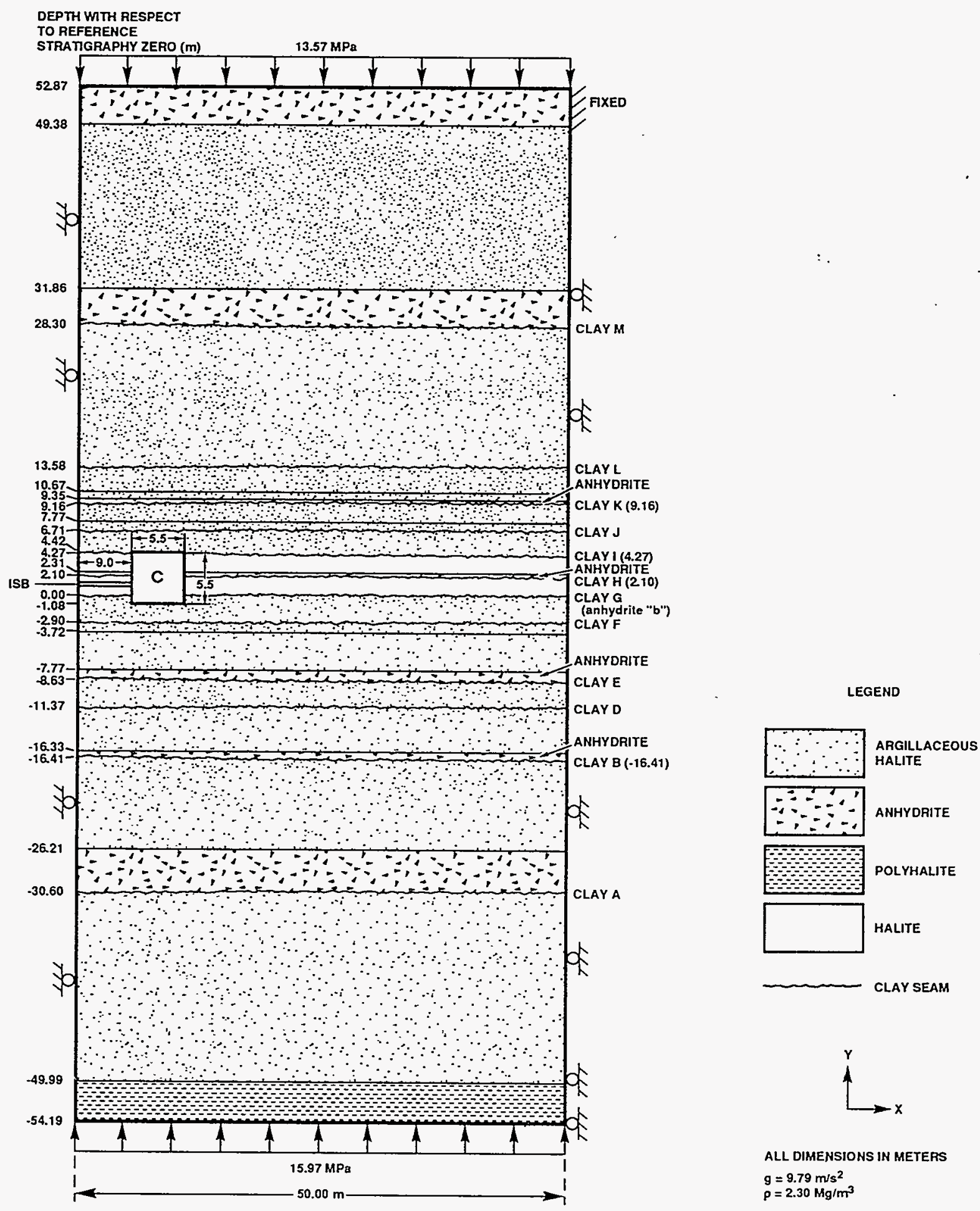

ALL DIMENSIONS IN METERS $\mathrm{g}=9.79 \mathrm{~m} / \mathrm{s}^{2}$ $\rho=2.30 \mathrm{Mg} / \mathrm{m}^{3}$

T/213012-1-1411 
Much later, the actual test construction was by Westinghouse, the operating contractor, using their underground crews. The drilling of the Intermediate Scale Borehole Test occurred in two steps. First, a small diameter pilot hole, $47.6 \mathrm{~mm}$ (1.875 in.), was drilled through the through the pillar from Room C2 into $\mathrm{C} 1$ using a Longyear ESH-38 drill. The pilot hole was drilled over a period of two days, $11 / 29 / 89$ and $11 / 30 / 89$. The vertical centerline of the pilot hole is in the middle of the clear salt layer found in the lower half of the room (see Figures 2.1.3 and 2.2.1). Thus, the pilot hole center is $1.62 \mathrm{~m}(5.30 \mathrm{ft})$ above the room floor. In order that the pilot hole location remain symmetrical and centered in the clear salt layer, the center line of the pilot hole dipped slightly as it goes from Rọom C2 to Room C1 to accommodate the dip in the geology.

Second, the intermediate scale borehole was cored using a Longyear ESH-38 drilling machine and a specially fabricated $0.90 \mathrm{~m}(3.0 \mathrm{ft})$ diameter core biț with a centralizer stem, which could core to a depth of about $1.02 \mathrm{~m}(1.35 \mathrm{ft})$. The core bit was guided by the pilot hole so the ISBT hole had the same centerline. Drilling was in stages to accommodate the finite length of core that could be taken at any one time with the core bit. At each stage, the drilling progressed to the depth of the core bit, then the bit was withdrawn from the hole leaving the core still attached at the bottom of the drill cut. The core length was broken loose and extracted from the hole. This operation continued until the hole was complete. At the rib, the top of the borehole was $2.06 \mathrm{~m}(6.76 \mathrm{ft}$ ) above the floor of Room $C 2$ and $0.41 \mathrm{~m}(1.35 \mathrm{ft})$ below the anhydrite layer "a." The bottom of the borehole was $1.14 \mathrm{~m}$ ( $3.74 \mathrm{ft}$ ) above the Room $\mathrm{C} 2$ floor and $0.47 \mathrm{~m}(1.54 \mathrm{ft})$ above the anhydrite layer "b." Details of the daily drilling operation are shown in the isometric of Figure 2.2.3. Except for 


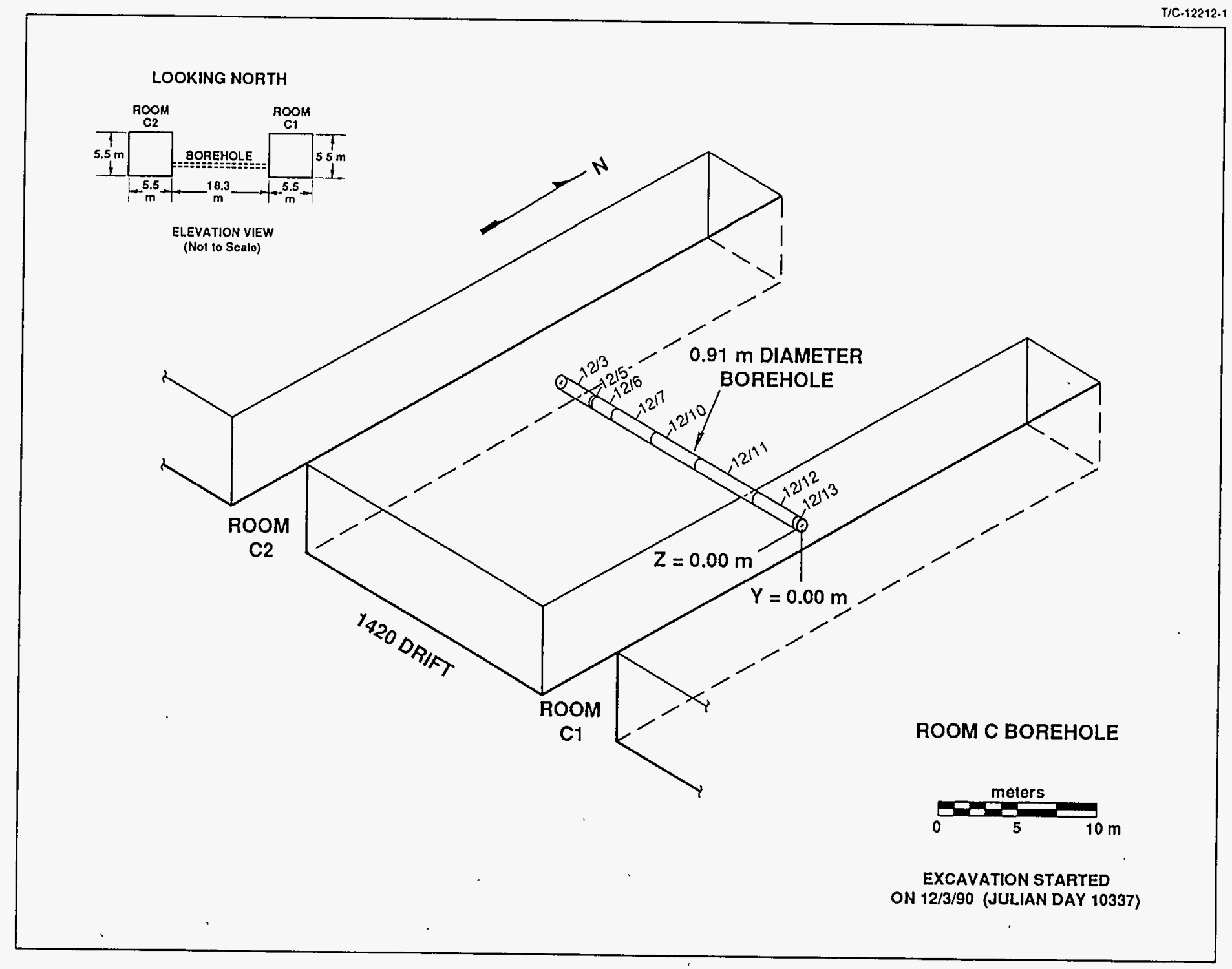

Figure 2.2.3. Isometric of Excavation Progress of the Intermediate Scale Borehole 
the very start of drilling when maintaining direction control presented some delay and then again a delay over the weekend, the excavation rate, as given in Figure 2.2.4, was quite uniform.

As previously noted, the excavation of the Rooms $C$ started on $3 / 17 / 84$ and finished on $4 / 9 / 84$. Some 6.7 years later, the drilling of the ISBT started on $12 / 3 / 90$ and was completed on $12 / 13 / 90$.

2.2.2 Instrumentation: Sandia-controlled drilling crews and instrumentation teams were responsible for installing all gages. The instrument drill holes were drilled some 2 to 11 months before the drilling of the intermediate scale borehole. These consisted of holes drilled into the salt mass of the pillar from Room C1, Room C2, and the N1420 entry drift. The ends of these holes were grouped around what would become principal stations at 0 (the pillar center), $-3,-6$, and $-9 \mathrm{~m}$ (the rib of Room (2). This concentrated the principal stations in the western half of the pillar; however, a number of principal stations with limited instrumentation were eventually established in the eastern half of the borehole as well. Drilling operations for the stress gages began in Room C2, progressed to Room C1, and then to the N1420 drift.

The first gages were installed from Room $C 2$ on $1 / 15 / 90$, including three of the four remote closure gages installed on the face of Room C2 (C2212, C2213, and C2214). The remainder of the BuMines and SGS stress gages were all installed by end of 6/90. Extensometers were installed concurrently with the stress gages to facilitate efficient use of the drilling equipment and minimize the down time due to drill rig set-up requirements. However, some additional gages not in the test plan were added from the $\mathrm{N} 1420$ drift so that seven of the 45 stress gages were actually installed between $9 / 90$ and $10 / 90$. Nearly $80 \%$ of the gages were 


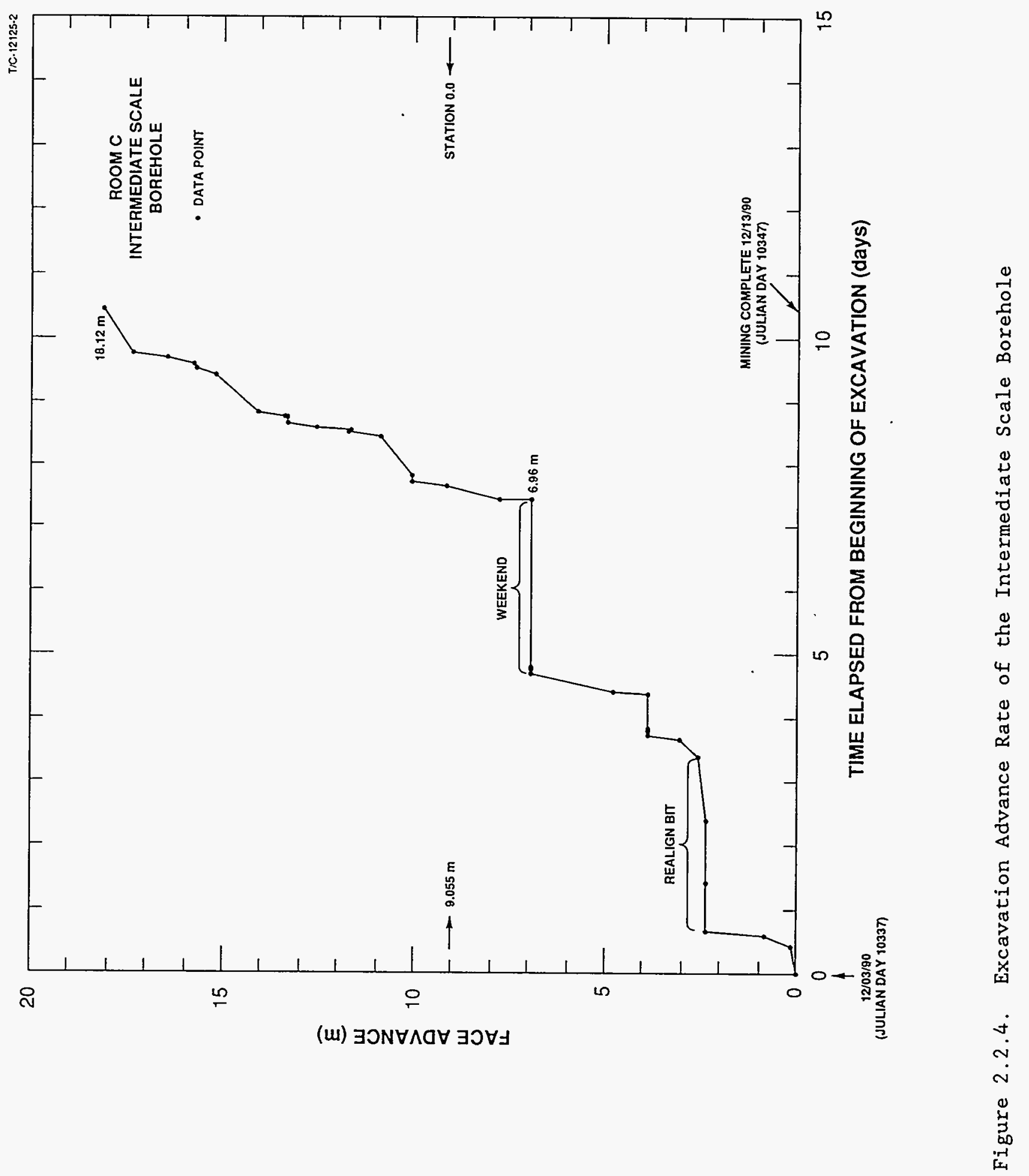


installed by $10 / 11 / 90$, somewhat less than two months before the start of the overcoring operations on $12 / 3 / 90$. Just before the coring of the intermediate scale borehole, the strain gages for measuring the vertical and horizontal closure of the pilot hole were installed. These gages were to be intentionally overcored. During core drilling of the intermediate scale borehole, mining sequence closure gages were installed as the coring operation made the station locations available. The instrumentation crew entered the hole after that segment of core at the appropriate station was removed and installed the closure station at the face of the drilling operation. Typically, these stations were installed within $1.0 \mathrm{~m}$ (3.33 $f t$ ) of the excavation face, and within three hours of the excavation of the station location. The fourth remote closure gage (C2211) on the face of Room C2 was installed on $12 / 17 / 90$ after coring activities were completed on $12 / 13 / 90$. The last gages, the permanent remote closure gages that monitor the vertical and horizontal closure of the borehole diameter, were installed between $1 / 10 / 91$ and $1 / 18 / 91$, replacing the manual gages.

2.2.3 Operation: The test has actually provided data since the installation of the gages in the pillar mass. Some of these gages were installed nearly a year before the intermediate scale borehole coring operation began. The early responses of these gages provide a baseline for the subsequent changes caused by the drilling of the borehole. The measured response after the borehole drilling operation showed significant shifts in measured levels from the baseline response. The instantaneous response of the gages to the excavation of the borehole was well documented, and the gages continue to be monitored. The data reported here includes only those to the cut off date of this report, June 1993. Total test duration was more than four years. 
Routine operation of the room involves any necessary maintenance of gages, including repair or replacement, if possible. It also involves the continued collection of data. The frequency of manual readings has diminished with time both because of availability of the remote reading gages and because of diminishing deformation rates. The frequency of remote reading of all active remote gages remains constant at the initial frequency of a reading every 4 hours.

\subsection{Special Features}

Certain special features of the fielding of the in situ tests relate directly to the analysis of the data presented here. Except for some gages fielded as special groups, most gages were fielded in groupings at "principal stations," and many of the displacement gages were "linked" together, both physically or in time. In the ISBT, gages and certain principal stations are related to each other by symmetry; and therefore, one would suppose a system of checks through gage redundancy could be readily established for the test. However, even though the pillar geometry suggests a vertical plane of symmetry, the excavation of the borehole was actually non-symmetrical so that in detail the gage responses cannot be compared based on pillar symmetry.

\subsubsection{Principal Stations: The test was designed assuming an ideal,} flat-lying, bedded-salt stratigraphy, which is also a common assumption for analysis using two- and three-dimensional numerical models. It was necessary to adapt the ideal design conditions appropriately to the actual field conditions of slightly dipping beds. As noted earlier, the field conditions required following the beds because of interbed partings in the roof. Actually, following the beds conforms to two-dimensionality because it preserves the fixed location of the opening with respect to the 
stratigraphy. However, location and installation of gages over the length of the borehole presented an interpolation problem. To minimize the problem, collections of gages were located relative to a local reference, called a principal station, always designated by an integer coordinate. Thus, it was possible to create a local reference at the principal station of a flat-lying coordinate system with the origin centered vertically at a principal station. The local coordinate system was an orthogonal system in $\mathrm{X}$ (east-west), $\mathrm{Y}$ (north- south) and $\mathrm{Z}$ (vertical) directions. The vertical coordinate center moved up and down according to the dip of the stratigraphy. Gages within about $1 \mathrm{~m}(3 \mathrm{ft})$ of the principal station were assigned to the station. As a consequence of the principal station concept, gages are given two sets of $\mathrm{Z}$ coordinates; one set is relative to the principal station zero, and the other set is relative to the test room coordinate zero. Use of principal stations not only simplifies fielding the gages but also aids considerably in analyzing the data. The small amount of dip in the actual pillar setting is automatically removed if the analysis is performed in principal station coordinates.

Although the cross sections of Figures 2.1.4a through 2.1.4e are related to the principal stations, and some indication of the gages associated with the stations can be determined from the figures, Table 2.3.1 organizes the gages according to their actual groupings as they were emplaced. The table also gives the principal station WISDAAM System directory name as contained in the data base management system [18].

2.3.2 Gage Linking: All TSI tests, including the ISBT, were designed to obtain a complete data history, insofar as possible. To do this, we linked the gages in both time sequence and physical sequence. The mining sequence closure gage stations were placed in proximity to the locations 
Table 2.3.1. ISBT Gages Grouped by Principal Stations

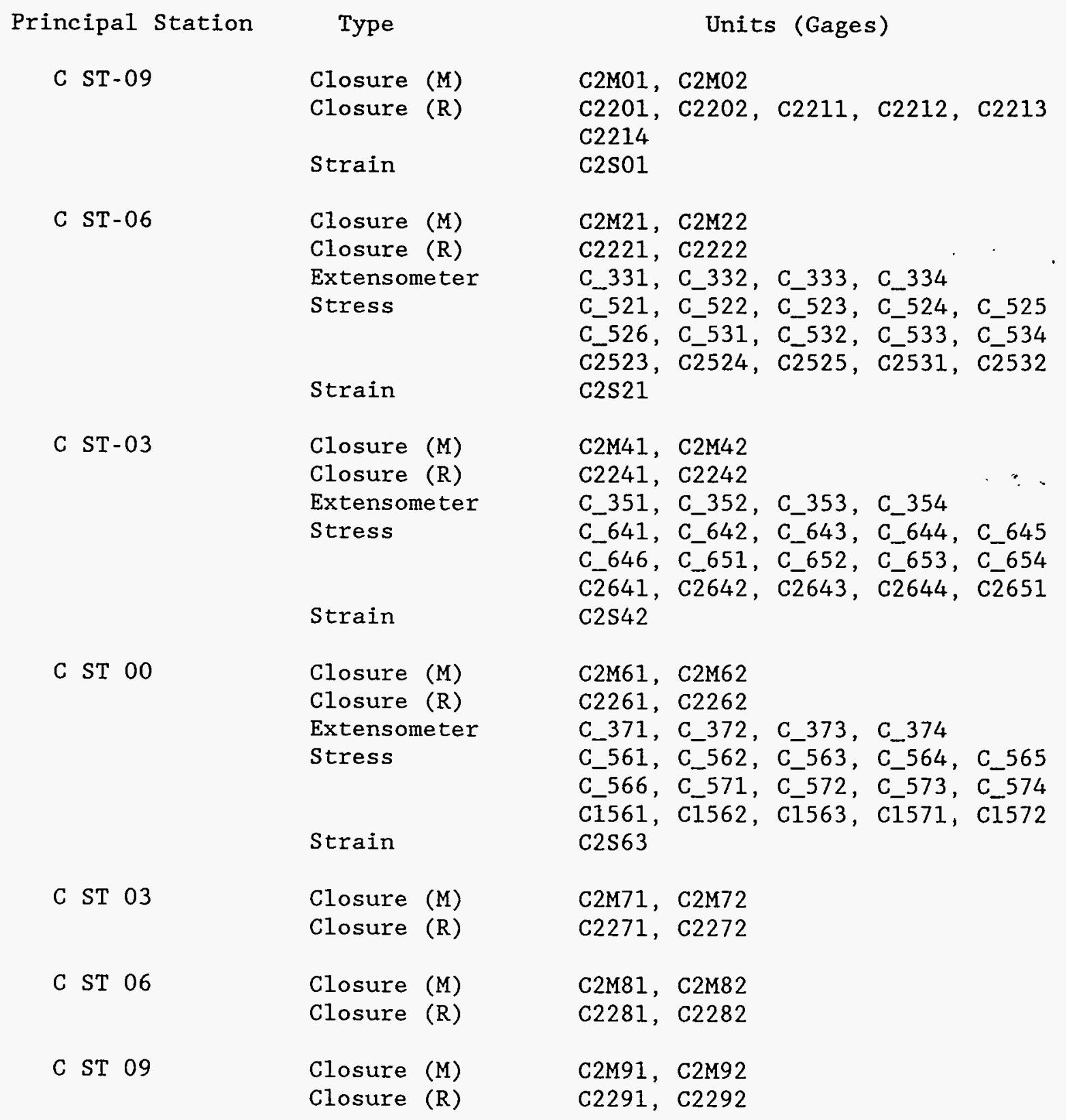


of future remote closure gage stations. In fact, the remote gages were placed on the mining sequence pin emplacements. As a result of this time linking, the very early closure values obtained manually can be linked to the later closures values obtained from the remote gages. The distances between these different gages stations were minimized so as to introduce as little error as possible when the data were linked to give the complete history of salt displacement at a given station. This time linking of closure data is discussed in detail in terms of the correct analysis in papers on Room B [21], Room D [22], and Rooms A [23] and is not treated further in this report.

Physical linking of the gages pertains only to permanent displacement gages associated with a given principal station. Physical linking originates in the details of gage installation in collared holes. All of the permanent gages were installed on $0.533 \mathrm{~m}$ (21.0 in.) long flanged pipe collars grouted $0.457 \mathrm{~m}(18.0 \mathrm{in.})$ into the salt. The outer flange surface of the collars served as the reference surface from which all disţances were measured for installation, as-built surveys, and displacements. In the case of the multipoint extensometers, the gage or unit was attached to and measured at the collar reference flange surface. The sharing of a common reference surface by all of the gages associated with the collar means that the displacements measured at a principal station are directly related to each other.

Although the ISBT gages were mounted on collars as in the case of the initial TSI tests, the ISBT is a special test in which the closure and extensometer gages were not physically linked. In fact, the closure and extensometer gages were in some cases actually emplaced at right angles to each other, and at different elevations. 
2.3.3 Special Gage Groups: There are collections of gages that have special relationships to each other, even though they may be distributed throughout the test room. These gages form logical groups that are treated as an analysis entity because they describe an important material or room response, or they provide a necessary parameter evaluation from the experiment. 


\section{DATA REDUCTION PROCESS}

The critical nature of data used in any development or other process involving repositories for the disposal of radioactive waste requires that all data collection, reduction, and analysis must be formally documented. This formalism is necessary for the R\&D activities of the technology development program, of which the TSI in situ tests are a part. Data reduction forms a part of a larger data collection, analysis, management, and documentation system developed for the in situ tests. This larger system is the WIPP In Situ Data Acquisition, Analysis, and Management (WISDAAM) System [18]. The important parts of the system for this data report are the data reduction and Quality Assurance (QA) procedures.

\subsection{WISDAAM System Functions}

Input to the raw data base is either manual (handwritten records) or remote (obtained by computer). Incorporating these data into a single, quality-controlled, reduçed data base requires considerable care.

3.1.1 Manual Data: Manual data are handwritten records concerning nearly all aspects of the in situ test; not just the actual gage data. For this report, however, only gage data concern us. These data are collected on special forms and placed into the QA-controlled WISDAAM Notebook System as raw data. This Notebook System, an appendix to the Test Plan for Room C [16], is maintained in the WIPP Central Files of the Waste Management Technology Library at SNL. From the raw data base, the data are entered into a computer-based management system using dBase III and reduced at individual IBM-AT computers. The result of the data reduction process is Certified Data, which indicates proper QA practice has been applied to the data collection and reduction. The certified data are transferred to the overall data base management VAX 8810 computer. 
Detailed explanations of the reduction process and the exact procedures for manual data are available [24].

3.1.2 Remote Data: The remotely collected data are obtained by the automated data acquisition system at the WIPP site [17]. Analog voltage data from individual gages are periodically interrogated by digital voltmeters located in underground instrument sheds adjacent to the in situ test. The digital data are transmitted by wire from the underground shed to a ModComp Classic 7840 computer at ground surface. Raw engineering values are calculated from raw voltages, gage calibrations, and conversion factors, and are stored as part of the raw data base. Periodically, the data are transferred by magnetic tape to the central WISDAAM System VAX 8810 computer. These tapes are considered part. of the QA-controlled WISDAAM Notebook System and retained in the SNL WIPP Central File. From the VAX 8810 computer system, raw data are compressed and reduced, and the resulting certified reduced data are stored in the VAX 8810 computer. Procedures for remote data reduction [25], descriptions of the WISDAAM system [18,26], and the UNDERDOG reduction system [27] are available.

\subsection{Quality Assurance (QA) Requirements}

Extensive QA procedures have been in practice before, during, and after fielding the in situ tests. These QA procedures begin with the SNL Quality Assurance Program Plan [28] for the Waste Isolation Pilot Plant (WIPP) and the specific QA requirements of the individual test plans.

The reduction process is compatible with overall QA requirements but includes QA features peculiar to a working data reduction system and the WISDAAM System. As a necessary requirement of the QA practice, all the raw and reduced data bases are periodically archived on.long-life (about 25 years), maintenance-free, optical disks. 
3.2.1 Reduction Levels: Because of the massive amount of raw data, the high level of overall $\mathrm{QA}$, and the need to document the reduction process, the project has defined several levels of data reduction associated with very specific activities and treatment of data:

Level 0 ... Raw data in the form of magnetic tape or paper records. Remote raw data are stored in the VAX 8810 computer; the manual raw data in the WISDAAM Notebook System.

Leve1 1 ...- Remote data compressed by removing non-data zeros, system flags, and redundant data (values identical within the least significant figure); and manual data entered into the VAX 8810 computer data base.

Level 2 ... All documented known-cause corrections to the manual and remote data are made and noted.

Level 3 ... All undocumented known-cause corrections to the manual and remote data are made and noted.

QA Stamped-- Level 3 data that are PI approved as Certified Data, published in a data report, and available for analysis.

Level 1 data reduction is relatively straightforward. Because raw remote data are collected on a very frequent schedule, many dafa change only in the places beyond the least significant figure. The Level 1 activity for remote data retains only one reading when readings are identical to the place of the least significant figure. At Level 1, raw manual data are transferred under close QA checks to a computer data base.

Level 2 data reduction for both remote and manual data are the corrections taken when a planned or inadvertent human activity involving the gage or data acquisition system alters the gage reading(s). Examples are power failure, gage maintenance, gage replacement, and intentional or 
accidental disconnection of a gage. Because of the QA requirement to document that activity, the exact time and the exact activity are known. Correction procedures for Level 2 data reduction are thus determined by the activity which altered the gage reading.

Level 3 data reduction activities are basically routine and involve a known problem of the gage response that is not the result of a planned or accidental human action. These problems result from gage peculiarities or uncontrolled events. Examples are gage hysteresis, an unpredictable event controlled by the gage; low-resistance shorts to ground because of collection of moisture; an undetected reading error; or a necessary routine reconstruction of zeros because of destruction of a gage point. When these events occur, it is apparent from a characteristic of the gage response; thus corrective actions can be determined and applied routinely.

In developing the data reduction procedures, we were extremely careful to assure that no activity was in the realm of analysis. In other words, no modifications or corrections were made during data reduction that required the application of abstract concepts, scientific judgments, or fundamental interpretations. Reduction levels were applied rigorously. All data reduction was documented by level for each gage.

3.2.2 Certified Data: After data reduction has been applied to a given gage and the data have progressed to the completion of Level 3 , the PI carefully checks to determine that (1) all reduction activities are proper, (2) all relevant data for the gage are included in the records, and (3) all QA requirements have been fulfilled. At this point, the PI is responsible for application of the QA Stamp to the data, which then is Certified Data. Certified Data are available to analysts for their use.

All the data in this report are Certified. 


\section{REDUCED DATA PRESENTATION}

Presentation of the large quantity of data from the ISBT, in exactly the manner matched to the needs of any specific analyst, is quite difficult. We can, however, present the data in a reasonable form and provide several keys that permit the analyst to find readily the desired collection of data.

The first key is found in Table 2.3.1. Because an analysis might logically center on a principal station or special group, all gages belonging to a principal station or a special group are shown in this table. This list can also be used to give the analyst a comprehensive overview of the location of instruments in the test. As noted previously, the gage number (or gage designation) contains specific gage information which indicates the test room, gage type, unit number, and gage number. Thus, it is possible to determine the gage type directly from the gage number. Another key at the beginning of each of the data sections is a location guide table showing the schematic location of each of the gages of that type by principal station. Use of the location guide permits identification of specialized groups of gages peculiar to the needs of the analyst. From the guide, for example, all the gage numbers for the vertically up oriented gages can be readily identified. Also, gage numbering generally follows a systematic pattern to aid in identifying direction or location.

All the data are presented in sections according to individual gage type, with the displacement data first (mining sequence, remote closure and extensometer), the stress data second, and the special strain gage data third. The data in each section are presented by gage number in ascending order. 
The format for each unit (in most cases a unit consists of several

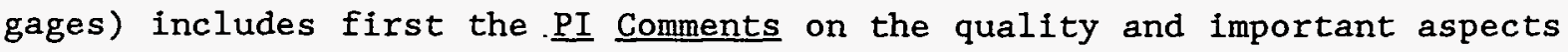
of the data reduction and the Location table specifying location and other relevant information concerning the unit (gages). The location of the gage is given in both room and principal station coordinates. Data for the gage(s) are then shown graphically. An explanation of each format item listed above is provided in the remainder of this chapter.

First let us consider only the remote gages. Several items in the PI Comments on remote gages require some explanation. The comments indicate the date of the evaluation, the initials of the person(s.) responsible for the data reduction, and a ranking of the gage. The ranking relates to the quality of the data collection, but not to the correctness of the data. In other words, the data could have very little meaning, in terms of analysis and physical correctness and still have a high rank. Thus, the rank is actually a measure of the number of reduction actions taken during the reduction process and the severity of these actions. In the case of stress meters, the rank is given as a percentage of data retained after elimination of obviously scattered and erroneous data. A specific scale was used to determine the gage rank value:

Rank 10 Outstanding. Very minor shifts or deletions of data, of which 958 or better are at Level 2, or data retention of $95 \%$ or better.

Rank 09 Exceptional. Reinstallation shifts and minor shifts and deletions of data, of which 908 or better are at Level 2, or data retention of 908 or better.

Rank 08 Excellent. Some additional minor deletion of data because of hysteresis at Level 3 , or data retention of $80 z$ or better. 
Rank 07 Very good. All reduction actions to some degree, including up to 308 at Level 3 , or data retention of 708 or better.

Rank 06 Good. All reduction actions, with marked deletions because of hysteresis, or data retention of 608 or better.

Rank 05 Fair. Marked shifts and deletions of data because of hysteresis, with up to 508 at Level 3 , with some of the major shifts undocumented at Level 2 (called arbitrary), and possible swapping of data channels or entanglement of wires, or data retention of $50 \%$ or better.

Rank 04 Marginal. Marked arbitrary shifts, major deletions of hysteresis, and unknown scatter, or apparently entangled gages requiring adjustment according to other gages, or data retention at only $40 \%$ or better.

Rank 03 Poor. Required excessive reduction, with adjustments according to other gages and sources, or data retention of only $30 \%$ or better.

Rank 02 Very poor. Excessive reduction, with reporting of data only for possible supporting information, or data retention at 208 or better.

Rank 01 Unacceptable. Reported primarily to show experimental problems, data retention less than 208 .

Rank 00 No Data. No data reduction possible for gage.

The PI Comments conclude with the Level 1 compression ratio for the unit or gage, which is the ratio of the number of raw data points to the number of Level 1 data points. The completely automatic Level 1 reduction for remote gages incorporates data compression. Data are compressed 
according to three rules: (1) data that are identical to within the significant figure (range) are redundant, and only one data point needs to be retained; (2) a data point will be retained every 3 days even though it may be redundant; (3) if a data point is retained on any gage of a unit, all comparable data points on that unit are retained.

For all TSI remote-gage data in the ISBT, the least significant figures (ranges) are:

$$
\begin{array}{ll}
\text { Time: } & 0.001 \mathrm{Jday} \text { (15 min). } \\
\text { Closure (displacement): } & 0.10 \mathrm{~mm} \text { (0.004 in.). } \\
\text { Extensometer (displacement): } & 0.10 \mathrm{~mm} \text { (0.004 in.). } \\
\text { Stress (pressure): } & 0.007 \mathrm{MPa} \text { ( } 1.0 \mathrm{psi}) .
\end{array}
$$

Note that, an option in Level 3 data reduction permits a compression of data similar to the Level 1 compression. This recompression option does not however affect the previous Level 1 compression ratio. The option is often applied to units where data scatter. on one gage causes excessive retention of redundant data on the other gages of the unit. It is also applied to the data of gages where the. least significant figure was intentionally small, such as the stress meter data. Intentionally small significant figures were usually chosen when it was not possible to set a reliable. initial value for a given gage type. After the first reduction, the observed scatter may suggest a reasonable recompression for that gage.

PI Comments for the manual data differ from those for remote gages. The manual gage data were not ranked since reduction actions were quite limited and involved few data. Also, there was no Level 1 compression of these data, and so the compression ratio of $1: 1$ applies.

For each gage there is one page of information. The table at the top of the page gives the PI Comments and Location information. The table 
indicates the specific gage number. Then the appropriate PI comments for the individual unit or gage are given, followed by location information giving the principal station and unit or gage station. This is followed by tabular entries that present the gage number and type, initial gage status (permanent or temporary), recording method (remote or manual), the direction (vertical, horizontal, or diagonal), the XYZ coordinate pairs for both ends of the gage with sets of $\mathrm{Z}$ in both principal station and room coordinates, gage manufacturer, initial installation date, purchase order and item number, and comments.

Beneath the tabular information on the page is a graph of the data for the unit or gage. Several items are included to aid the viewer. The room, gage (or unit) number, type of gage, station and principal station are shown in the upper left corner. In most cases, a cartạon cross section showing the physical location of the gage(s) is given in the upper right corner. The cartoon gives the symbol legend for the gages. Thus, a square symbol is always gage 1 , a diamond gage 2 , an " $x$ " gage 3 , a triangle gage 4, a circle gage 5, and a "f" gage 6. In some cases the cartoon is replaced by a conventional symbol legend. Also, the origin is linked to the calendar and Julian day (Jday) on which the gage was installed. An abbreviated form of Julian day is used in which the first two numbers are the number of years since 1980 and reflect indirectly the calendar year and the remaining numbers are the total days of the year to that day. Consequently, it is possible to arithmetically manipulate Julian days in modulo 365 (and leap year 366 ).

All the reduced manual data are included on the graphs of these data. However, to make the graphs of the remote data clearer, we eliminated many of the actual data points so that the symbols are distinct. If this were 
not done, the data would have been so dense that the symbols would be illegible. This increased clarity is illustrated by comparing Figure 4.0.1, which is a stress plot containing all of the Level 3 data points, and Figure 4.0.2, which is the same plot with the elimination of overlapping data points. This presentation clarification process is again not a true Level 1 compression. Another interesting and potentially useful feature of the graphs is that the displacements are often plotted to identical. scales and can therefore be easily compared directly by overlaying them. 


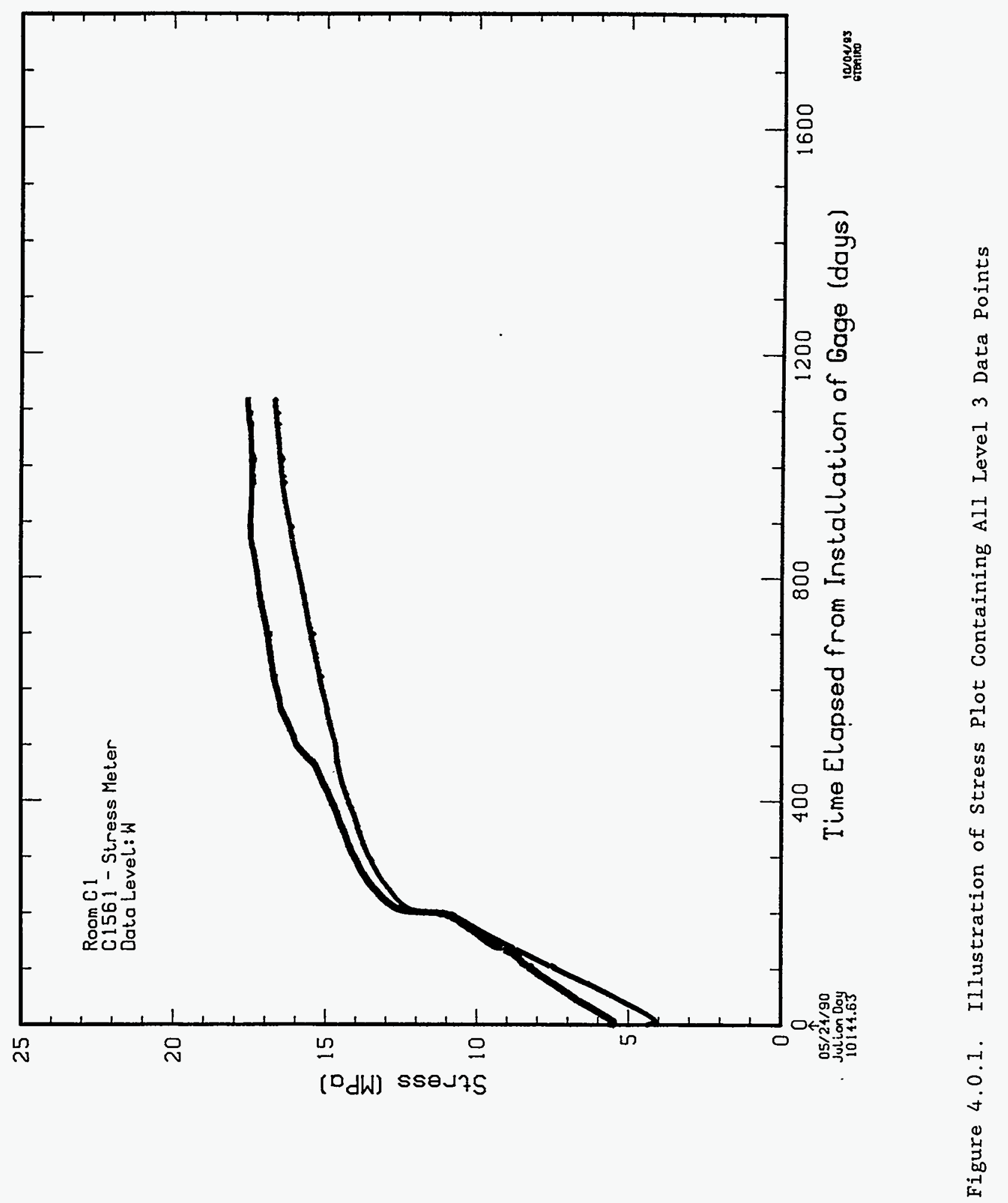




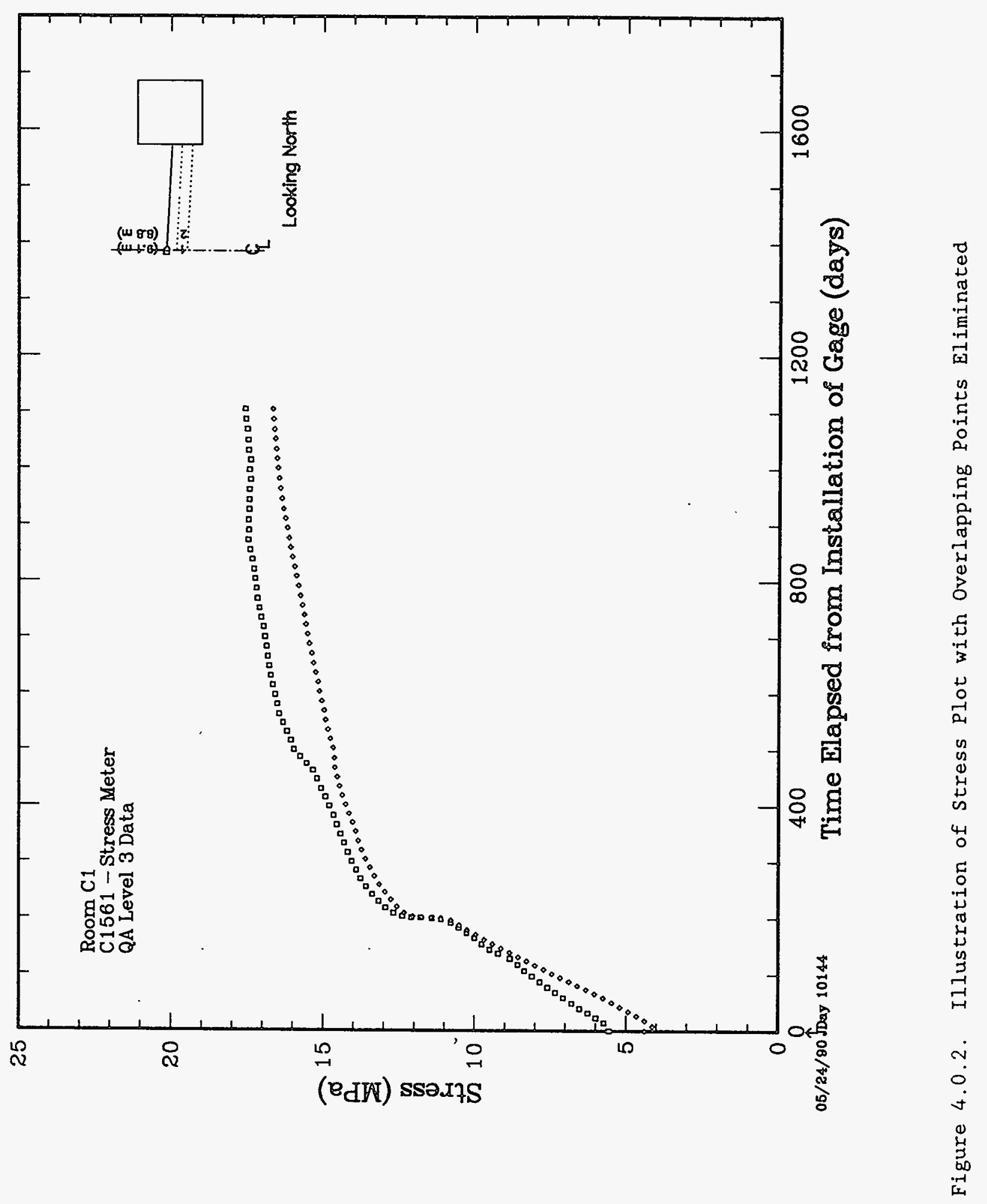




\section{REDUCED DATA}

Before we discuss the data of each gage type, please note a very significant appraisal of data quality: the data about to be presented are of truly high quality. This is noteworthy because they were obtained from a very large scale underground field test under harsh and congested environmental conditfons and under occasionally difficult operational constraints. They would be judged of superior quality even against typical laboratory data obtained under ideal conditions. With time, of course, deterioration of the test is expected through gage failure, which means the gage cannot be fepaired or replaced.

The data return was also remarkable, by any measure. Of the 205 mechanical response gages (93 units) that were fielded (1.e., closure, displacement, stress and strain) every gage initially produced data, except for two stress gages that could not be pressurized as planned when installed.

This total of 205 gages includes 4 strain units ( 8 gages) in the pilot hole that were destroyed intentionally during the drilling operation and 14 mining sequence gages that were replaced rather soon by remote reading gages mounted directly on the earlier mining sequence gage pins. If we assume failure to be a nonmaintainable condition leading to obviously incorrect data and voluntary or involuntary discontinuation of recording, we can give the failure rates for the remaining 183 permanent closure, extensometer, and stress gages for the period of January 1989 to June 1993. None of the permanently mounted remote closure gages have to this point failed. For the 60 remote extensometer gages only 4 gages have completely failed, however, an additional 20 gages were mined out when the core drill intercepted the extensometer instrument holes. The gages were 
reinstalled, but not always successfully. In fact, the four units (20 gages) that were mined out and entirely reinstalled exhibited marked hysteresis and three of these units (15 gages) have not yet been able to produce good data. If all of the bad extensometer gages are included, then 19 of the initial 60 gages or $32 \%$ have failed. For the 105 stress gages (45 BuMines and $60 \mathrm{SGS}$ ), 2 BuMines gages were inactive from the beginning. Of the remaining stress gages, 13 gages have failed (18 BuMines and 5 SGS) and a further 7 (5 BuMines and 2 SGS) were lost when the transducer cables were cut during drilling of the intermediate scale borehole. Thus, some $30 \%$ of the stress gages are no longer active.

of the 183 remote closure, extensometer, and stress gages initially installed, 51 or $28 \%$ are now inactive or not producing reliable data; however, this actualiy represents only about 168 of the potential data since most gages were active over some portion of the test duration represented in this report.

Even though" the duration of this unheated test is currently short compared to the other TSI tests, the survival rate for gages and data recovery is still considered exceptional.

\subsection{Displacement Measurements}

Displacement measurements were obtained from both manually and remotely read closure gages placed throughout the borehole, and by remotely read extensometers. Although these gages are the same as used in the other TSI tests, they differ in how they were implemented into the ISBT. : In the other tests, gage installation occurred as soon as the test room was excavated, with the intent of recording as much deformation as possible. In the ISBT, only the closure gages installed in the borehole as it was being drilled, and subsequent to the completion of the borehole, 
conformed to this procedure. The closure gages mounted on the face of the pillar surface and the extensometers were all installed well in advance of the drilling of the ISBT to provide a baseline response. However, this was still well after excavation of Rooms $C 1$ and $C 2$. As a consequence, these gages measure essentially a small segment of the total deformation history. Most were specific only to the influence of drilling the ISBT on the pillar. In general, it is not possible to adequately relate this segment to the complete deformation history of the rooms. In fact, these rooms were not initially included in the planned TSI in situ testing program, and were not instrumented because they were intended only as a demonstration mpck-up area for canister installation.

Both the manual and remote borehole closure gage data are reported, as usual. What differs in this report is that the mining sequence closure data, which constitutes most of the manual closure data, are included here as well, because they were currently available. These data are also found in a report documenting all of the mining sequence data collected at the WIPP [15]. The fact that both are included here, in the same report, permits the easy reconstruction of the entire closure history, without seeking data from two independent data reports, as has been the case for the other TSI in situ tests.

In addition to the remote closure gages installed to replace the borehole manual gages, remote closure gages were mounted on the rib of Room C2 to monitor the rib shortening due the construction of the ISBT. Because of an erroneous location of some of the planned extensometer gages, and the addition of others to correct the error, some gages were installed only a couple of months in advance. While the different installation times change the appearance of the data records, it seems 
that sufficient base line response was obtained for all of the gages. However, interpretation of the results must account for different installation times.

Because the extensometer gages were installed in the mass of salt in the pillar adjacent to the location of the ISBT, the gages reflect the changes caused by the drilling of the hole. In general, these changes are pronounced. In some cases, the drilling of the borehole destroyed the initial installation of extensometer wires and anchors. When it was possible to do so, the destroyed gages were reinstalled. 
5.1.1 Manual (Mining Sequence) Closure Measurements: A Location guide showing the schematic location for the manually read mining sequence gages is given in Table 5.1.1. This table shows the vertical and horizontal gages eștablished at the drilling face in the borehole as it was being drilled. Normally, the closure station was established within one core length, about $1.0 \mathrm{~m}(1.28 \mathrm{ft})$, and within no more than 3 hours of the time of the excavation of the intended station. Gage designations suggest both the location and orientation of the gage. The vertical closure units are designated as C2Mxx, with the last digit of the unit number being a "1", and horizontal closure units designations have a "2" as the last digit. The seven pairs of units are equally spaced along the length of the borehole, with one set at each end of the borehole.

The appropriate mining (drilling) sequence gage information is given in Tables 5.1.2a-g and the mining sequence closure data are displayed in Figures 5.1.1a-g. These data also appeared in a report dealing solely with mining sequence measurements at the WIPP [15], which contains greater detail on the mining sequence gages. Please note, because monitoring of the mining sequence gages was for only a short period of time before they were replaced by remote gages, a single 50 day graph of the data is all that can be given. The remotely measured closure gages were mounted directly on the mining sequence closure pins, and as a result, these gages are directly physically linked to each other, but sequential in time.

As is apparent, because the ISBT was drilled in a single pass, the data require no special reduction procedures to correct for mined out closure points. As previously noted, the gages measured all of the displacement except for that deformation which occurs in advance of the drilling face, a partial measure of this deformation was made in the test 
Table 5.1.1. ISBT Mining Sequence Closure Gages Location Guide

Station Direction

C2ST-09

$\begin{array}{ll}\text { Vertical } & \text { roof } \\ \text { Horizontal } & \text { mid } \\ \text { Vertical } & \text { floor }\end{array}$

C2ST-06

Vertical roof

Horizontal mid

Vertical floor

C2ST-03

Vertical roof

Horizontal mid

Vertical floor

C2ST 00

- Vertical roof

Horizontal mid

Vertical floor

C2ST 03

Vertical roof

Horizontal mid

Vertical floor

\section{Relative Location \\ center south}
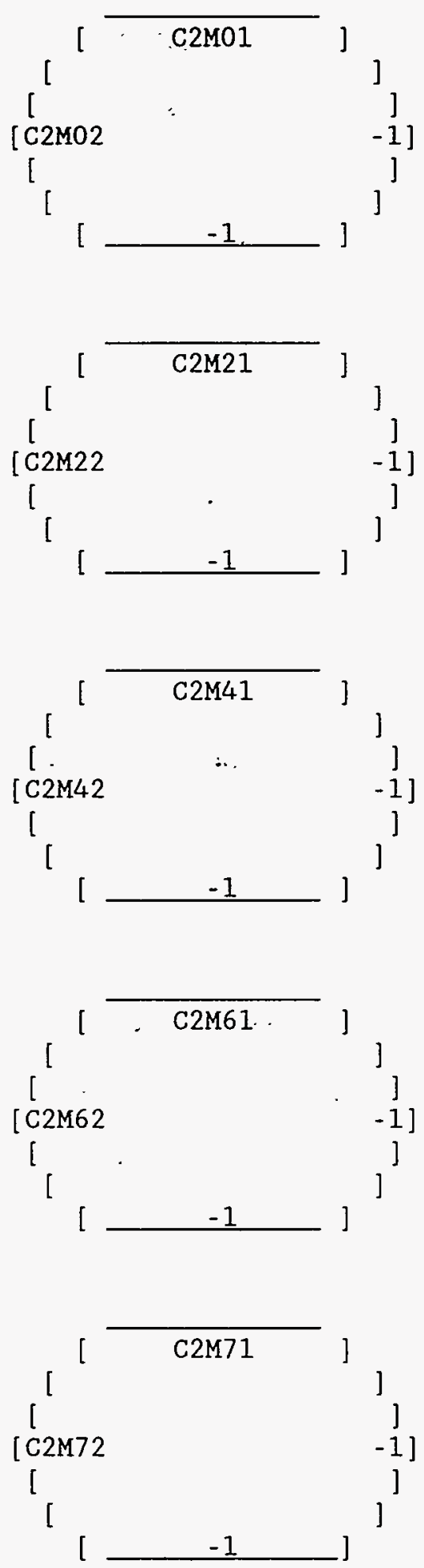
Table 5.1.1. ISBT Mining Sequence Closure Gages Location Guide (Cont.)

Station Direction

C2ST 06

\section{north south}

$\begin{array}{ll}\text { Vertical } & \text { roof } \\ \text { Horizontal } & \text { mid } \\ \text { Vertical } & \text { floor }\end{array}$

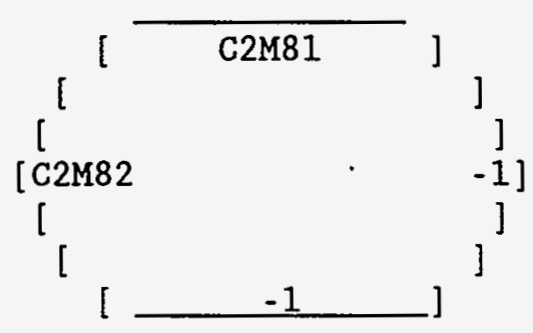

C2ST 09

$\begin{array}{ll}\text { Vertical roof } & \\ \text { Horizontal mid } & \\ \text { Vertical floor }\end{array}$

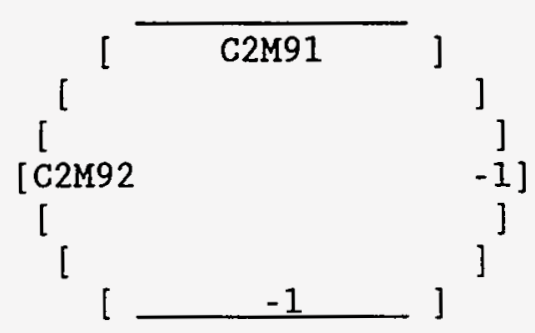

using the strain gages, as described later. In fact, calculation of this effect under progressive mining conditions suggests that the deformation is small compared to the measured deformations [29].

Measured vertical closures are greater than the horizontal closures; this is undoubtedly a result of the existing stress field in the pillar. The measured closures in the ISBT are small compared to those normally associated with the TSI tests because the hole diameter is much less than the TSI test room dimensions. The relatively small displacements compared to the reading accuracy accentuate the scatter in these data.

Although one would expect the displacements to scale with the initial room diameter for excavations into an initial lithostatic stress field, the severe three-dimensional stress field in the pillar precludes such easy analysis. 
Table 5.1.2a. Mining Sequence Gages C2M0X-x, ISBT, Station $-09 \mathrm{~m}$

C2M01 - C2M02 PI Comments

03/11/92 RLJ [95\%] This set of Mining Sequence Closure Gages (1 vertical and 1 horizontal) was installed very close to the borehole collar (less than one meter). They were first measured less than 3 hours after excavation. Data were collected for about 40 days, then the gage was replaced with a remotely read gage. The closure magnitude is much different for these gages, in fact closure is reduced by more than $98 \%$ when compared to closure in larger rectangular rooms. Gage disruption due to mining required no reinstallations. It is apparent that the horizontal closure as measured by $\mathrm{C} 2 \mathrm{MO2}$ for this station almost at the rib of Room $\mathrm{C} 2$ is very nearly nonexistant and is quite different than the closures at stations deeper into the pillar. (DEM)

Gage Information

\begin{tabular}{llclllll} 
Gage Number & Gage Type & $\begin{array}{c}\text { Gage } \\
\text { Orient. }\end{array}$ & - Record - & & $\begin{array}{c}\text { Gage } \\
\text { Manf. }\end{array}$ & $\begin{array}{c}\text { Installation } \\
\text { Date }\end{array}$ & $\begin{array}{c}\text { Drawing } \\
\text { Number }\end{array}$ \\
\hline C2M01-1 & CONV & V & T & MAN & SNL & $12 / 3 / 90$ \\
C2M02-1 & CONV & H & T & MAN & SNL & $12 / 3 / 90$
\end{tabular}

Gage Location

Gage Coordinates

\begin{tabular}{ccccccccc} 
& & & & \multicolumn{3}{c}{ - Local一 } & \multicolumn{2}{c}{ Room - } \\
Gage Number & $\mathrm{X} 1(\mathrm{~m})$ & $\mathrm{X} 2(\mathrm{~m})$ & $\mathrm{Y} 1(\mathrm{~m})$ & $\mathrm{Y} 2(\mathrm{~m})$ & $\mathrm{Z} 1(\mathrm{~m})$ & $\mathrm{Z} 2(\mathrm{~m})$ & $\mathrm{Z} 1(\mathrm{~m})$ & $\mathrm{Z} 2(\mathrm{~m})$ \\
\hline & & & & & & & & \\
C2M01-1 & -8.86 & -8.86 & 0.00 & 0.00 & -0.46 & 0.46 & -0.01 & 0.92 \\
C2M02-1 & -8.81 & -8.86 & -0.47 & 0.47 & 0.00 & 0.00 & 0.46 & 0.46
\end{tabular}

Gage Length Upon Installation

Pass 1

Pass 2

Pass 3

Pass $4+$ Trim

-Final-

\begin{tabular}{|c|c|c|c|c|c|c|c|c|c|}
\hline $\begin{array}{l}\text { Gage } \\
\text { Number }\end{array}$ & Dir & Gage & $\begin{array}{l}\text { Length } \\
(\mathrm{m})\end{array}$ & Gage & $\begin{array}{l}\text { Length } \\
\text { (m) }\end{array}$ & Gage & $\begin{array}{l}\text { Length } \\
\text { (m) }\end{array}$ & Gage & $\begin{array}{l}\text { Length } \\
\text { (m) }\end{array}$ \\
\hline $\begin{array}{l}\mathrm{C} 2 \mathrm{MO1} \\
\mathrm{C} 2 \mathrm{MO2}\end{array}$ & $\begin{array}{l}\mathrm{V} \\
\mathrm{H}\end{array}$ & $\begin{array}{l}-1 \\
-1\end{array}$ & $\begin{array}{l}0.95 \\
0.97\end{array}$ & & $\begin{array}{l}\text { None } \\
\text { None }\end{array}$ & & $\begin{array}{l}\text { None } \\
\text { None }\end{array}$ & $\begin{array}{l}-1 \\
-1\end{array}$ & $\begin{array}{l}0.95 \\
0.97\end{array}$ \\
\hline
\end{tabular}

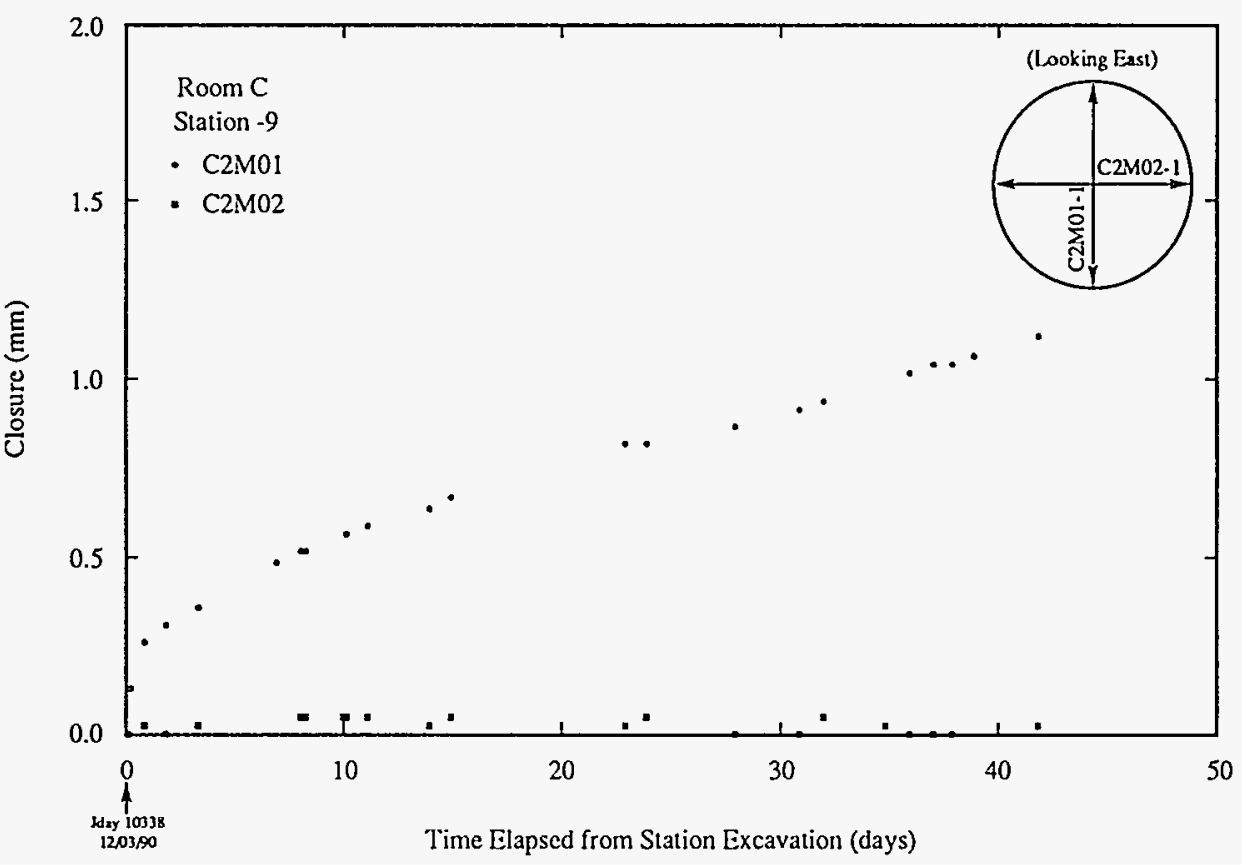

Figure 5.1.1a. Mining Sequence Gages C2M0X-X, ISBT, Station -09 m 
Table 5.1.2b. Mining Sequence Gages C2M $2 \mathrm{x}-\mathrm{x}$, ISBT, Station $-06 \mathrm{~m}$

\section{C2M21 - C2M22 PI Comments}

03/18/92 RLJ [98\%] This set of Mining Sequence Closure Gages (1 vertical and 1 horizontal) was installed one sixth the distance between rooms $\mathrm{Cl}$ and $\mathrm{C} 2$. They were first measured about 4 hours after excavation. Data were collected for about 39 days, then the gage was replaced with a remotely read closure gage. The closure magnitude is much lower for these gages in this small diameter excavation, in fact closure is reduced by more than $98 \%$ when compared to closure in larger rectangular rooms. The horizontal displacement is less than the vertical, probably as a result of the stresses in the pillar. Gage disnuption due to mining required no reinstallations. (DEM)

\begin{tabular}{|c|c|c|c|c|c|c|c|}
\hline & \multirow[b]{2}{*}{$\begin{array}{c}\text { Gage } \\
\text { Orient. }\end{array}$} & & & \multirow[b]{2}{*}{$\begin{array}{l}\text { Gage } \\
\text { Manf. }\end{array}$} & \multirow[b]{2}{*}{$\begin{array}{c}\text { Installation } \\
\text { Date } \\
\end{array}$} & \multirow[b]{2}{*}{$\begin{array}{l}\text { Drawing } \\
\text { Number } \\
\end{array}$} \\
\hline Gage Number & Gage Type & & 二 & ord - & & & \\
\hline C2M21-1 & CONV & $\mathrm{V}$ & $T$ & $\overline{M A}$ & SNL & $12 / 6 / 90$ & \\
\hline C2M22-1 & CONV & $\mathrm{H}$ & $T$ & MAN & SNL & $12 / 6 / 90$ & \\
\hline
\end{tabular}

Gage Location

\begin{tabular}{ccccccccc} 
& \multicolumn{1}{c}{ Gage Coordinates } \\
Gage Number & $X 1(\mathrm{~m})$ & $\mathrm{X} 2(\mathrm{~m})$ & $\mathrm{Y} 1(\mathrm{~m})$ & $\mathrm{Y} 2(\mathrm{~m})$ & $\mathrm{Z1}(\mathrm{m})$ & $\mathrm{Z} 2(\mathrm{~m})$ & $\mathrm{Z1}(\mathrm{m})$ & $\mathrm{Z} 2(\mathrm{~m})$ \\
\hline C2M21-1 & -6.12 & -6.12 & 0.00 & 0.00 & -0.48 & 0.48 & -0.17 & 0.79 \\
C2M22-1 & -6.12 & -6.12 & -0.48 & 0.48 & 0.00 & 0.00 & 0.31 & 0.31
\end{tabular}

Gage Length Upon Installation

$$
\text { Pass } 1 \text { Pass } 2 \text { Pass } 3 \quad \text { Pass } 4+\text { Trim }
$$

\begin{tabular}{|c|c|c|c|c|c|c|c|c|c|}
\hline \multirow[b]{2}{*}{ Gage Number } & \multirow[b]{2}{*}{ Dir } & \multicolumn{2}{|c|}{$10 \mathrm{~s}$} & \multicolumn{2}{|c|}{ - } & \multicolumn{2}{|c|}{ - } & \multicolumn{2}{|c|}{-Final- } \\
\hline & & Gage & $\begin{array}{l}\text { Length } \\
\text { (m) }\end{array}$ & Gage & $\begin{array}{l}\text { Length } \\
\text { (m) }\end{array}$ & Gage & $\begin{array}{l}\text { Length } \\
(\mathrm{m})\end{array}$ & Gage & $\begin{array}{l}\text { Length } \\
\text { (m) }\end{array}$ \\
\hline $\begin{array}{l}\text { C2M21 } \\
\text { C2M22 }\end{array}$ & $\begin{array}{l}V \\
H\end{array}$ & $\begin{array}{l}-1 \\
-1\end{array}$ & $\begin{array}{l}0.95 \\
0.96\end{array}$ & & $\begin{array}{l}\text { None } \\
\text { None }\end{array}$ & & $\begin{array}{l}\text { None } \\
\text { None }\end{array}$ & $\begin{array}{l}-1 \\
-1\end{array}$ & $\begin{array}{l}0.95 \\
0.96\end{array}$ \\
\hline
\end{tabular}

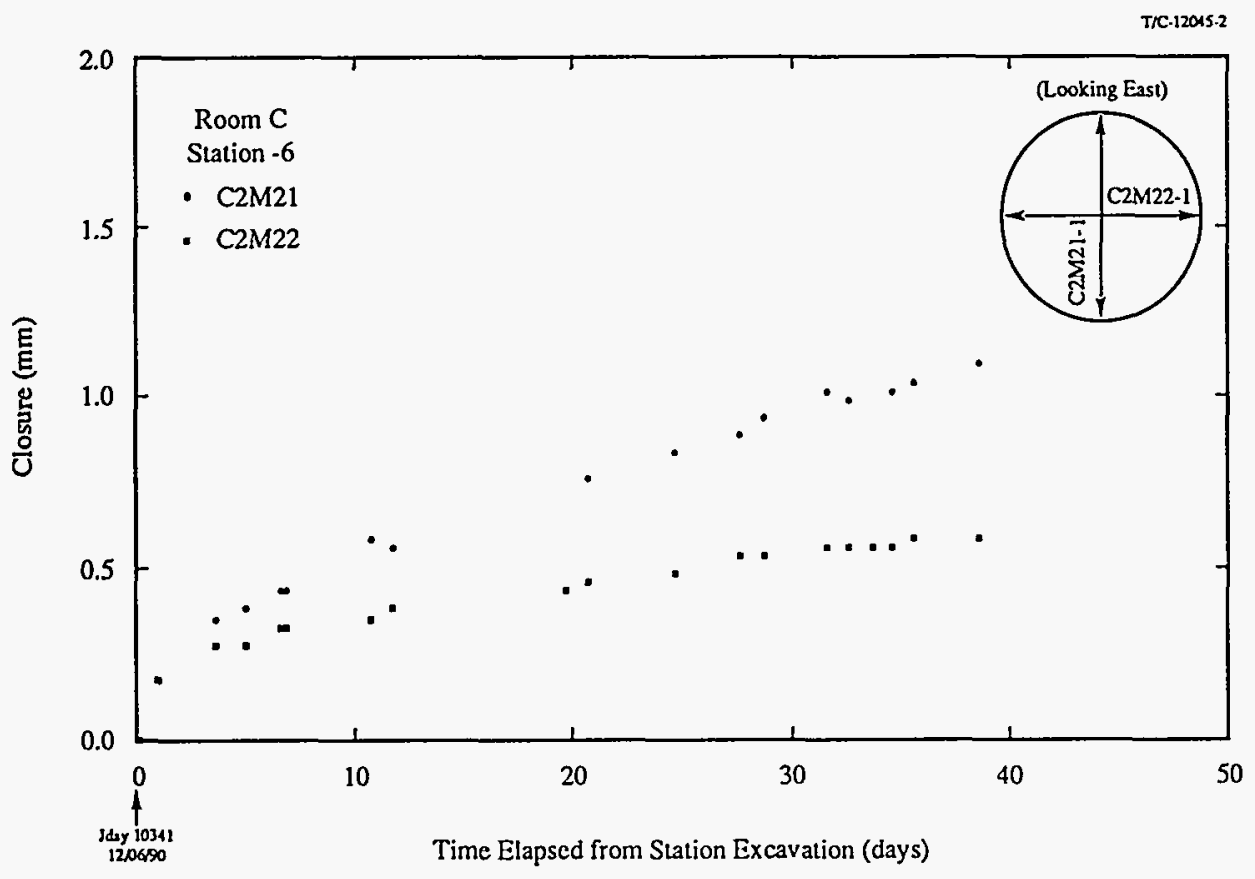

Figure 5.1.1b. Mining Sequence Gages C2M2x-x, ISBT, Station $-06 \mathrm{~m}$ 
Table 5.1.2c. Mining Sequence Gages C2M4x-x, ISBT, Station $-03 \mathrm{~m}$

\section{C2M41 - C2M42 PI Comments}

03/19/92 RLJ [989] This set of Mining Sequence Closure Gages (1 vertical and 1 horizontal) was installed one third the distance belween rooms $\mathrm{Cl}$ and C2. They were first measured about 2 hours after excavation. Data were collected for about 34 days, then the gage was replaced with a remotely read closure gage. The closure magnitude is much lower for these gages in this small excavation, in fact closure is reduced by more than $98 \%$ when compared to closure in larger rectangular rooms. The horizontal displacement is less than the vertical, probably as a result of the stresses in the pillar. Gage disruption due to mining required no reinstallations. (DEM)

Gage Information

\begin{tabular}{|c|c|c|c|c|c|c|c|}
\hline Gage Number & Gage Type & $\begin{array}{c}\text { Gage } \\
\text { Orient. }\end{array}$ & - & id - & $\begin{array}{l}\text { Gage } \\
\text { Manf. }\end{array}$ & $\begin{array}{c}\text { Installation } \\
\text { Date }\end{array}$ & $\begin{array}{l}\text { Drawing } \\
\text { Number }\end{array}$ \\
\hline C2M41-1 & CONV & $\mathrm{V}$ & $\mathrm{T}$ & MAN & SNL & $12 \pi / 90$ & \\
\hline C2M42-1 & CONV & $\mathrm{H}$ & $\mathrm{T}$ & MAN & SNL. & $12 \pi / 90$ & \\
\hline
\end{tabular}

Gage Location

Gage Coordinates

\begin{tabular}{|c|c|c|c|c|c|c|c|c|}
\hline \multirow[b]{3}{*}{ Gage Number } & \multirow[b]{3}{*}{$\mathrm{X} 1 \mathrm{(m)}$} & \multirow[b]{3}{*}{$\mathrm{X} 2(\mathrm{~m})$} & \multirow[b]{3}{*}{$Y 1(\mathrm{~m})$} & \multicolumn{3}{|c|}{ Uage Coordinates } & \multirow{2}{*}{\multicolumn{2}{|c|}{ - Room _ }} \\
\hline & & & & & $\boldsymbol{x}$ & $\mathrm{cal}=-2+2$ & & \\
\hline & & & & $\mathrm{Y} 2(\mathrm{~m})$ & $\mathrm{Zl}(\mathrm{m})$ & $\mathrm{Z2}(\mathrm{m})$ & $\mathrm{Zl}(\mathrm{m})$ & $\mathrm{Z2}(\mathrm{m})$ \\
\hline C2M41-1 & -3.08 & -3.08 & 0.00 & 0.00 & -0.48 & 0.48 & -0.30 & 0.65 \\
\hline $\mathrm{C} 2 \mathrm{M} 42-1$ & -3.08 & -3.08 & -0.48 & 0.48 & 0.00 & 0.00 & 0.17 & 0.17 \\
\hline
\end{tabular}

Gage Length Upon Installation

\begin{tabular}{|c|c|c|c|c|c|c|c|c|c|}
\hline \multirow[b]{2}{*}{ Gage Number } & \multirow[b]{2}{*}{ Dir } & \multicolumn{2}{|c|}{ Pass 1} & \multicolumn{2}{|c|}{ Pass 2} & \multicolumn{2}{|c|}{ Pass 3} & \multicolumn{2}{|c|}{$\begin{array}{l}\text { Pass } 4+\text { Trim } \\
\text {-Final- }\end{array}$} \\
\hline & & Gage & $\begin{array}{l}\text { Length } \\
\text { (m) }\end{array}$ & Gage & $\begin{array}{c}\text { Length } \\
(\mathrm{m})\end{array}$ & Gage & $\begin{array}{c}\text { Length } \\
\text { (m) }\end{array}$ & Gage & $\begin{array}{l}\text { Length } \\
\text { (m) }\end{array}$ \\
\hline $\begin{array}{l}\mathrm{C} 2 \mathrm{M} 41 \\
\mathrm{C} 2 \mathrm{M} 42\end{array}$ & $\begin{array}{l}\mathrm{V} \\
\mathrm{H}\end{array}$ & $\begin{array}{l}-1 \\
-1\end{array}$ & $\begin{array}{l}0.95 \\
0.95\end{array}$ & & $\begin{array}{l}\text { None } \\
\text { None }\end{array}$ & & $\begin{array}{l}\text { None } \\
\text { None }\end{array}$ & $\begin{array}{l}-1 \\
-1\end{array}$ & $\begin{array}{l}0.95 \\
0.95\end{array}$ \\
\hline
\end{tabular}

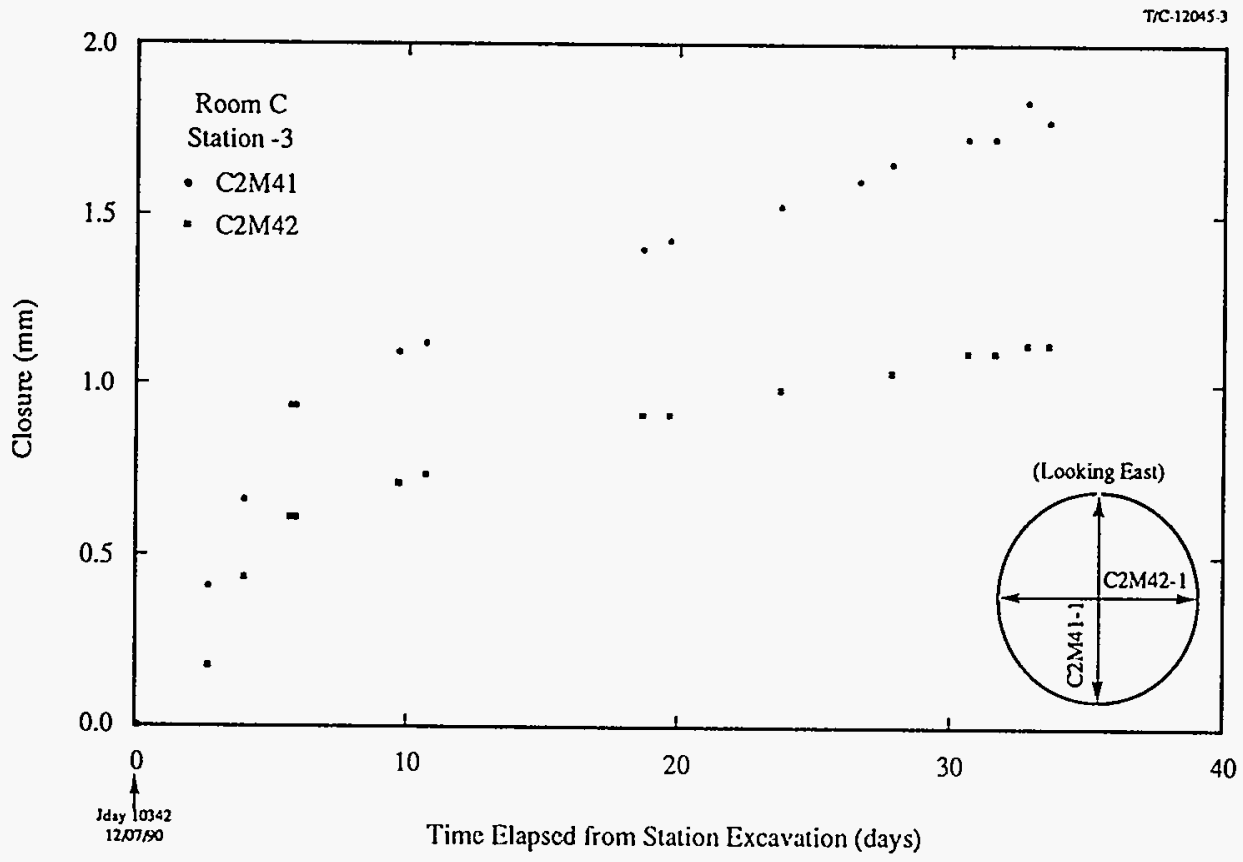

Figure 5.1.1c. Mining Sequence Gages C2M4x-x, ISBT, Station $-03 \mathrm{~m}$ 
Table 5.1.2d. Mining Sequence Gages C2M6x-x, ISBT, Station $00 \mathrm{~m}$

\section{C2M61 - C2M62 PI Comments}

05/07/92 RLJ [96\%] This set of Mining Sequence Closure Gages (1 vertical and 1 horizontal) was installed one half the distance between rooms $\mathrm{Cl}$ and $\mathrm{C} 2$. They were first measured about 4 hours after excavation. Data were collected for only 17 days, then the gage was replaced with a remotely read closure gage. The closure magnitude is much lower for these gages in this small diameier tesh in fact closure is reduced by more than $98 \%$ when compared to closure in larger rectangular rooms. The horizontal displacement is less than the vertical, probably as a result of the stresses in the pillar. Gage disruption due to mining required no reinstallations. (DEM)

Gage Information

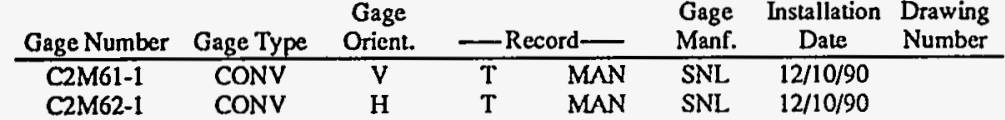

Gage Location

\begin{tabular}{ccccccccc} 
& \multicolumn{8}{c}{ Gage Coordinates } \\
Gage Number & $\mathrm{X} 1(\mathrm{~m})$ & $\mathrm{X} 2(\mathrm{~m})$ & $\mathrm{Y} 1(\mathrm{~m})$ & $\mathrm{Y} 2(\mathrm{~m})$ & $\mathrm{Z} 1(\mathrm{~m})$ & $\mathrm{Z2}(\mathrm{m})$ & $\mathrm{Z} 1(\mathrm{~m})$ & $\mathrm{Z} 2(\mathrm{~m})$ \\
\hline C2M61-1 & -0.04 & -0.04 & 0.00 & 0.00 & -0.48 & 0.48 & -0.48 & 0.48 \\
C2M62-1 & -0.04 & -0.04 & -0.48 & 0.48 & 0.00 & 0.00 & 0.00 & 0.00
\end{tabular}

Gage Length Upon Installation

\begin{tabular}{|c|c|c|c|c|c|c|c|c|c|}
\hline \multirow[b]{2}{*}{ Gage Number } & \multirow[b]{2}{*}{ Dir } & \multicolumn{2}{|c|}{ Pass 1} & \multicolumn{2}{|c|}{ Pass 2} & \multicolumn{2}{|c|}{ Pass 3} & \multicolumn{2}{|c|}{$\begin{array}{c}\text { Pass } 4+\text { Trim } \\
\text {-Final- }\end{array}$} \\
\hline & & Gage & $\begin{array}{l}\text { Length } \\
\text { (m) }\end{array}$ & Gage & $\begin{array}{l}\text { Length } \\
\text { (m) }\end{array}$ & Gage & $\begin{array}{l}\text { Length } \\
\text { (m) }\end{array}$ & & $\begin{array}{c}\text { Length } \\
\text { (m) }\end{array}$ \\
\hline $\begin{array}{l}\text { C2M61 } \\
\text { C2M62 }\end{array}$ & $\begin{array}{l}V \\
H\end{array}$ & $\begin{array}{l}-1 \\
-1\end{array}$ & $\begin{array}{c}0.96 \\
0.976\end{array}$ & & $\begin{array}{l}\text { None } \\
\text { None }\end{array}$ & & $\begin{array}{l}\text { None } \\
\text { None }\end{array}$ & $\begin{array}{l}-1 \\
-1\end{array}$ & $\begin{array}{l}0.96 \\
0.96\end{array}$ \\
\hline
\end{tabular}

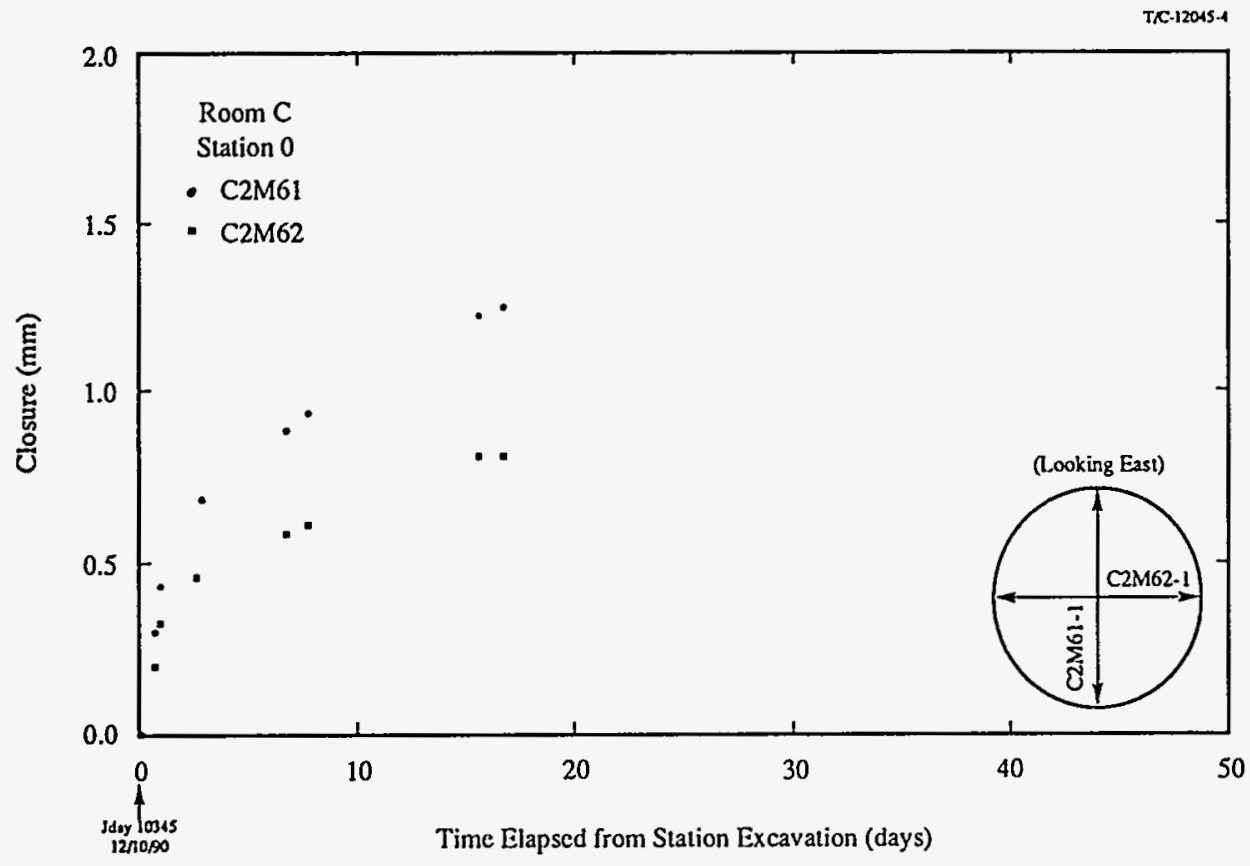

Figure 5.1.1d. Mining Sequence Gages C2M6x-x, ISBT, Station $00 \mathrm{~m}$ 
Table 5.1.2e. Mining Sequence Gages C2M7x-x, ISBT, Station +03 $\mathrm{m}$

\section{C2M71 - C2M72 PI Comments}

05/07/92 RLJ [93\%] This set of Mining Sequence Closure Gages (1 vertical and 1 horizontal) was installed two thirds the distance between rooms $\mathrm{Cl}$ and $\mathrm{C}$. They were first measured about 5 hours after excavation. Data were collected for about 37 days, then the gage was replaced with a remotely read closure gage. The closure magnitude is much lower for these gages in this small diameter test, in fact closure is reduced by more than $98 \%$ when compared to closure in larger rectangular rooms. The horizontal closure is less than the vertical, probably as a result of the stresses in the pillar. Gage distuption due to mining required no reinstallations. (DEM)

Gage Information

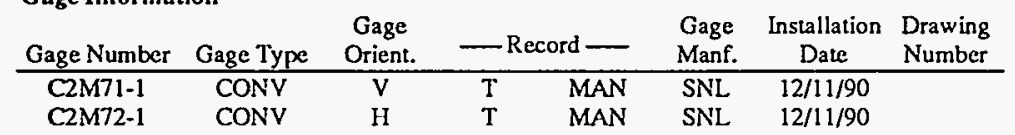

Gage Location

\begin{tabular}{ccccccccc} 
& \multicolumn{9}{c}{ Gage Coordinates } \\
Gage Number & $X 1(\mathrm{~m})$ & $\mathrm{X} 2(\mathrm{~m})$ & $\mathrm{Y1}(\mathrm{m})$ & $\mathrm{Y} 2(\mathrm{~m})$ & $\mathrm{Z1}(\mathrm{m})$ & $\mathrm{Z} 2(\mathrm{~m})$ & & \multicolumn{2}{c}{ Z1 $(\mathrm{m})$} & $\mathrm{Z} 2(\mathrm{~m})$ \\
\hline C2M71-1 & 3.01 & 3.01 & 0.00 & 0.00 & -0.33 & 0.63 & -0.48 & 0.48 \\
C2M72-1 & 3.01 & 3.01 & -0.48 & 0.48 & 0.00 & 0.00 & -0.15 & -0.15
\end{tabular}

Gage Length Upon Installation

\begin{tabular}{|c|c|c|c|c|c|c|c|c|c|}
\hline \multirow[t]{2}{*}{ Gage Length $\mathrm{L}$} & \multirow[b]{2}{*}{ Dir } & \multicolumn{2}{|c|}{ on Pass 1} & \multicolumn{2}{|c|}{ Pass 2} & \multicolumn{2}{|c|}{ Pass 3} & \multicolumn{2}{|c|}{$\begin{array}{c}\text { Pass } 4+\text { Trim } \\
\text {-Final- }\end{array}$} \\
\hline & & Gage & $\begin{array}{c}\text { Length } \\
(\mathrm{m})\end{array}$ & Gage & $\begin{array}{l}\text { Length } \\
(\mathrm{m})\end{array}$ & Gage & $\begin{array}{c}\text { Length } \\
(\mathrm{m})\end{array}$ & & $\begin{array}{c}\text { Length } \\
(\mathrm{m})\end{array}$ \\
\hline $\begin{array}{l}\text { C2M71 } \\
\text { C2M72 }\end{array}$ & $\begin{array}{l}\mathrm{V} \\
\mathrm{H}\end{array}$ & $\begin{array}{l}-1 \\
-1\end{array}$ & $\begin{array}{l}0.96 \\
0.97\end{array}$ & & $\begin{array}{l}\text { None } \\
\text { None }\end{array}$ & & $\begin{array}{l}\text { None } \\
\text { None }\end{array}$ & $\begin{array}{l}-1 \\
-1\end{array}$ & $\begin{array}{c}0.9560 .9 \\
7\end{array}$ \\
\hline
\end{tabular}

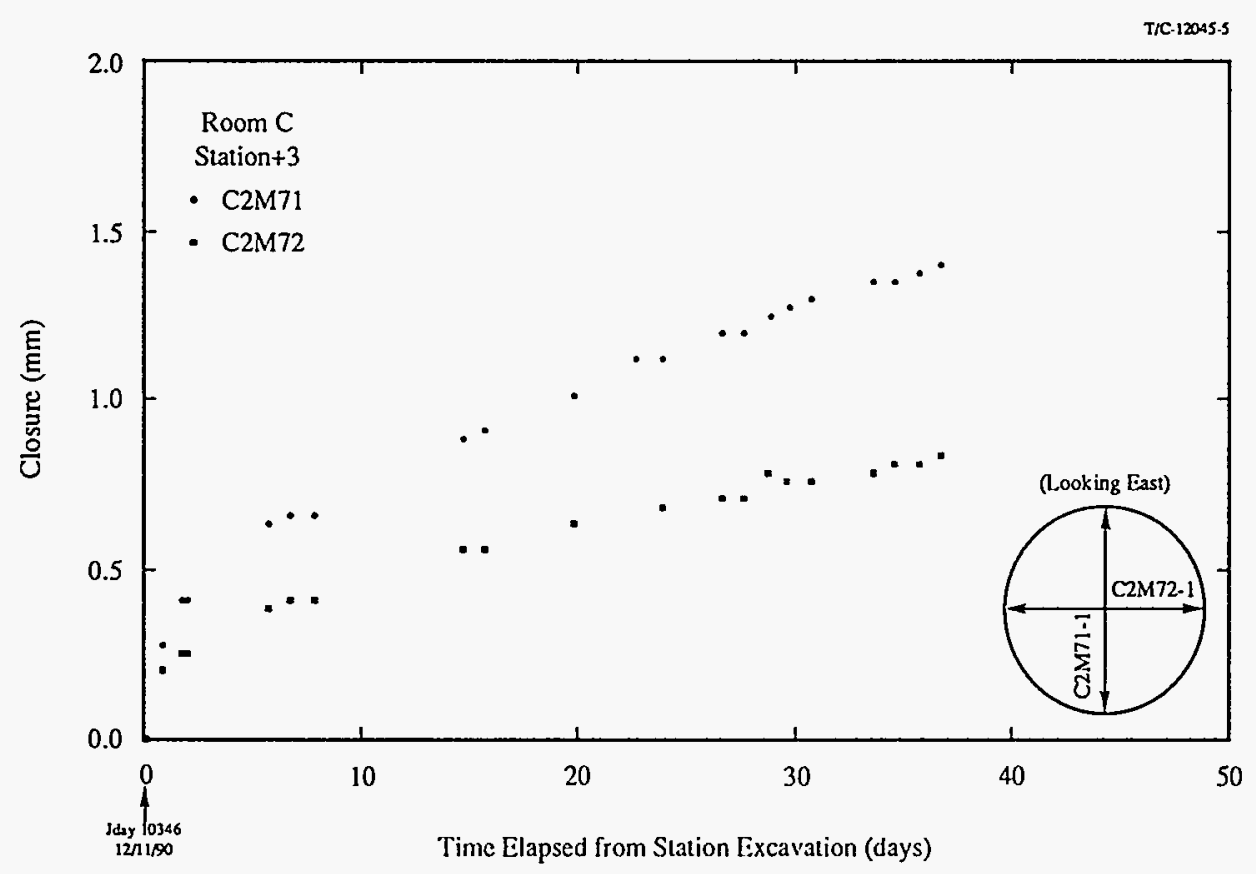

Figure 5.1.1e. Mining Sequence Gages C2M7x-x, ISBT, Station +03 $\mathrm{m}$ 
Table 5.1.2f. Mining Sequence Gages C2M8x-x, ISBT, Station +06 m

\section{C2M81 - C2M82 PI Comments}

05/07/92 RLJ [95\%] This set of Mining Sequence Closure Gages (1 vertical and 1 horizontal) was installed five sixths the distance between rooms $\mathrm{Cl}$ and $\mathrm{C}$. They were first measured about 4 hours after excavation. Data were collected for about 36 days, then the gage was replaced with a remotely read closure gage. The closure magnitude is much lower for these gages in this small diameter test, in fact closure is reduced by more than $98 \%$ when compared to closure in larger rectangular rooms. The horizontal closure is less than the vertical, perhaps as the result of the stress field in the pillar. Gage disruption due to mining required no reinstallations. (DEM)

\begin{tabular}{|c|c|c|c|c|c|c|c|}
\hline \multirow{2}{*}{\multicolumn{2}{|c|}{ Gage Information }} & \multirow[b]{2}{*}{$\begin{array}{l}\text { Gage } \\
\text { Orient. }\end{array}$} & & & \multirow[b]{2}{*}{$\begin{array}{l}\text { Gage } \\
\text { Manf. }\end{array}$} & \multirow[b]{2}{*}{$\begin{array}{c}\text { Installation } \\
\text { Date }\end{array}$} & \multirow[b]{2}{*}{$\begin{array}{l}\text { Drawing } \\
\text { Number }\end{array}$} \\
\hline & & & -1 & rd- & & & \\
\hline C2M81-1 & & $\mathrm{V}$ & $T$ & $\mathrm{MA}$ & SNL & $12 / 12 / 90$ & \\
\hline C2M82-1 & CONV & $\mathrm{H}$ & $\mathrm{T}$ & MAN & SNL & $12 / 12 / 90$ & \\
\hline
\end{tabular}

Gage Location

Gage Coordinates

\begin{tabular}{ccccccccc} 
& & & \multicolumn{1}{c}{-Local- } & \multicolumn{2}{c}{ - Room } \\
Gage Number & $\mathrm{X} 1(\mathrm{~m})$ & $\mathrm{X} 2(\mathrm{~m})$ & $\mathrm{Y} 1(\mathrm{~m})$ & $\mathrm{Y} 2(\mathrm{~m})$ & $\mathrm{Zl}(\mathrm{m})$ & $\mathrm{Z2}(\mathrm{m})$ & $\mathrm{Zl} \mathrm{(m)}$ & $\mathrm{Z} 2(\mathrm{~m})$ \\
\hline C2M81-1 & 6.05 & 6.05 & 0.00 & 0.00 & -0.48 & 0.48 & -0.79 & 0.17 \\
C2M82-1 & 6.05 & 6.05 & -0.48 & 0.48 & 0.00 & 0.00 & -0.31 & -0.31
\end{tabular}

\begin{tabular}{|c|c|c|c|c|c|c|c|c|c|}
\hline Gage Length $L$ & Insta & & ss 1 & & ss 2 & & ss 3 & $\begin{array}{r}\text { Pass } \\
-F\end{array}$ & $\begin{array}{l}\text { Trim } \\
\text { al- }\end{array}$ \\
\hline Gage Number & Dir & Gage & $\begin{array}{l}\text { Length } \\
(\mathrm{m})\end{array}$ & Gage & $\begin{array}{l}\text { Length } \\
(\mathrm{m})\end{array}$ & Gage & $\begin{array}{l}\text { Length } \\
(\mathrm{m})\end{array}$ & Gage & $\begin{array}{l}\text { Length } \\
\text { (m) }\end{array}$ \\
\hline $\begin{array}{l}\text { C2M81 } \\
\text { C2M82 }\end{array}$ & $\begin{array}{l}\mathrm{V} \\
\mathrm{H}\end{array}$ & $\begin{array}{l}-1 \\
-1\end{array}$ & $\begin{array}{l}0.96 \\
0.97\end{array}$ & & $\begin{array}{l}\text { Nonc } \\
\text { None }\end{array}$ & & $\begin{array}{l}\text { None } \\
\text { None }\end{array}$ & $\begin{array}{l}-1 \\
-1\end{array}$ & $\begin{array}{l}0.96 \\
0.97\end{array}$ \\
\hline
\end{tabular}

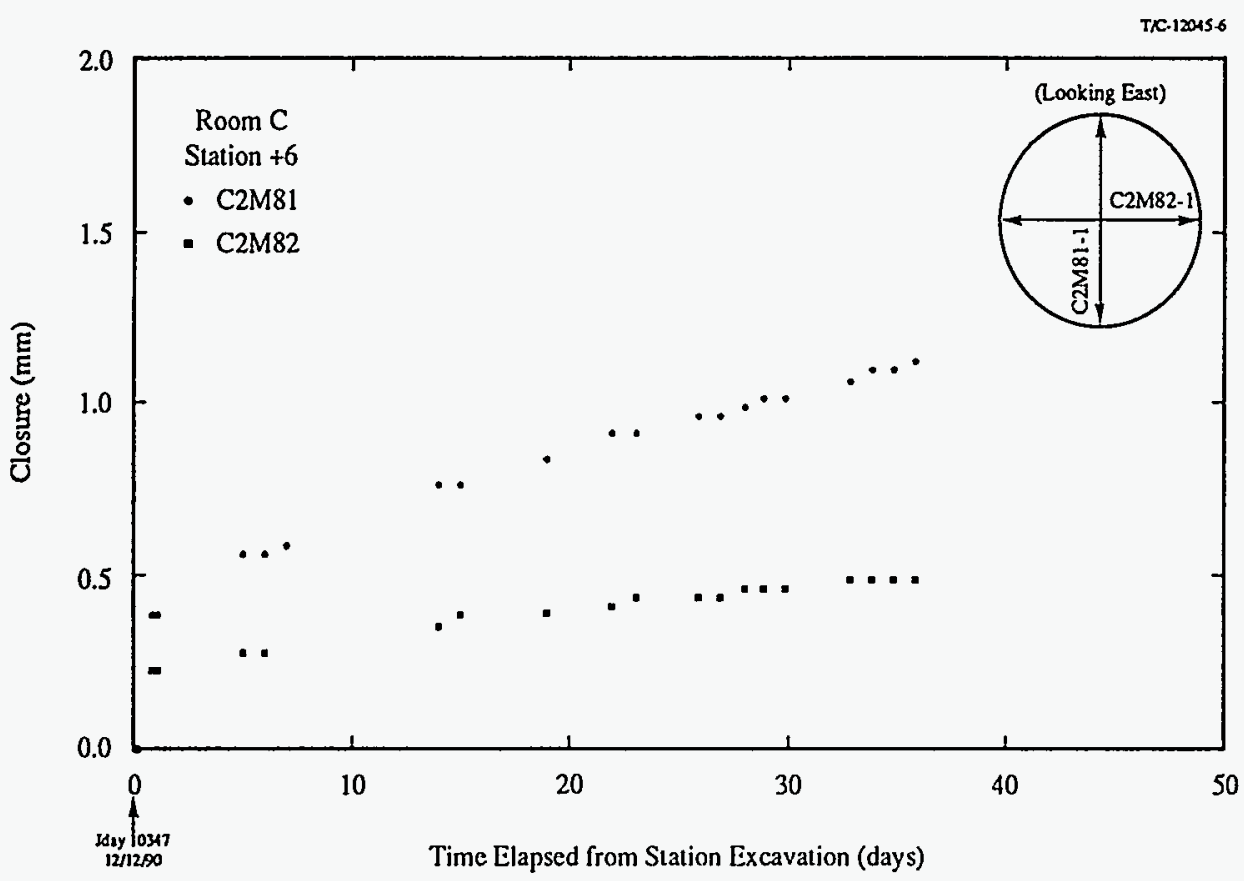

Figure 5.1.1f. Mining Sequence Gages C2M8x-x, ISBT, Station +06 m 
Table 5.1.2g. Mining Sequence Gages C2M9x-x, ISBT, Station +09 $\mathrm{m}$

\section{C2M91 - C2M92 PI Comments}

05/07/92 RLJ [93\%] This set of Mining Sequence Closure Gages (1 vertical and 1 horizontal) was installed less than one meter from the borehole break out into Room C1. They were furst measured less than 3 hours after excavation. Data were collected for about $\mathbf{4 0}$ days, then the gage was replaced with a remotely read gage. The closure magnitude is much different for these gages in a small diameter excavation, in fact closure is reduced by more than $98 \%$ when compared to closure in larger rectangular rooms.

The closures measured at this station are less than at stations in the middle of the pillar: moreover, they differ from those measured at the collar of the hole. Because this unsupported hole would be expected to undergo larger displacements, the smaller measured closures compared to the pillar center are a result of missing considerable displacement that occurs before the gages are installed. The behavior at both the collar and break out stations are quite complex. Gage disruption due to mining required no reinstallations. (DEM)

Gage Information

\begin{tabular}{|c|c|c|c|c|c|c|c|}
\hline Gage Number & Gage Type & $\begin{array}{c}\text { Gage } \\
\text { Orient. }\end{array}$ & 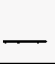 & ird - & $\begin{array}{l}\text { Gage } \\
\text { Manf. }\end{array}$ & $\begin{array}{c}\text { Installation } \\
\text { Date }\end{array}$ & $\begin{array}{l}\text { Drawing } \\
\text { Number }\end{array}$ \\
\hline C2M91-1 & CONV & V & $T$ & MAN & & $12 / 13 / 90$ & \\
\hline C2M92-1 & CONV & $\mathrm{H}$ & $\mathrm{T}$ & MAN & & $12 / 13 / 90$ & \\
\hline
\end{tabular}

Gage Location

\begin{tabular}{ccccccccc} 
& \multicolumn{1}{c}{ Gage Coordinates } \\
Gage Number & $\mathrm{X} 1(\mathrm{~m})$ & $\mathrm{X} 2(\mathrm{~m})$ & $\mathrm{Y} 1(\mathrm{~m})$ & $\mathrm{Y} 2(\mathrm{~m})$ & $\mathrm{Z} 1(\mathrm{~m})$ & $\mathrm{Z} 2(\mathrm{~m})$ & $\mathrm{Z} 1(\mathrm{~m})$ & $\mathrm{Z} 2(\mathrm{~m})$ \\
\hline C2M91-1 & 8.79 & 8.79 & 0.00 & 0.00 & -0.48 & 0.48 & -0.93 & 0.03 \\
C2M92-1 & 8.79 & 8.79 & -0.48 & 0.48 & 0.00 & 0.00 & -0.45 & -0.45
\end{tabular}

Gage Length Upon Installation

\begin{tabular}{|c|c|c|c|c|c|c|}
\hline Pass 1 & \multicolumn{2}{|c|}{ Pass 2} & \multicolumn{2}{|c|}{ Pass 3} & \multicolumn{2}{|c|}{$\begin{array}{l}\text { Pass } 4+\text { Trim } \\
\text {-Final- }\end{array}$} \\
\hline $\begin{array}{l}\text { Length } \\
\text { (m) }\end{array}$ & Gage & $\begin{array}{l}\text { Length } \\
(\mathrm{m})\end{array}$ & Gage & $\begin{array}{l}\text { Length } \\
(\mathrm{m})\end{array}$ & Gage & $\begin{array}{l}\text { Length } \\
\text { (m) }\end{array}$ \\
\hline $\begin{array}{l}0.96 \\
0.96\end{array}$ & & $\begin{array}{l}\text { None } \\
\text { None }\end{array}$ & & $\begin{array}{l}\text { None } \\
\text { None }\end{array}$ & $\begin{array}{l}-1 \\
-1\end{array}$ & $\begin{array}{l}0.96 \\
0.96\end{array}$ \\
\hline
\end{tabular}

TC.12045.7

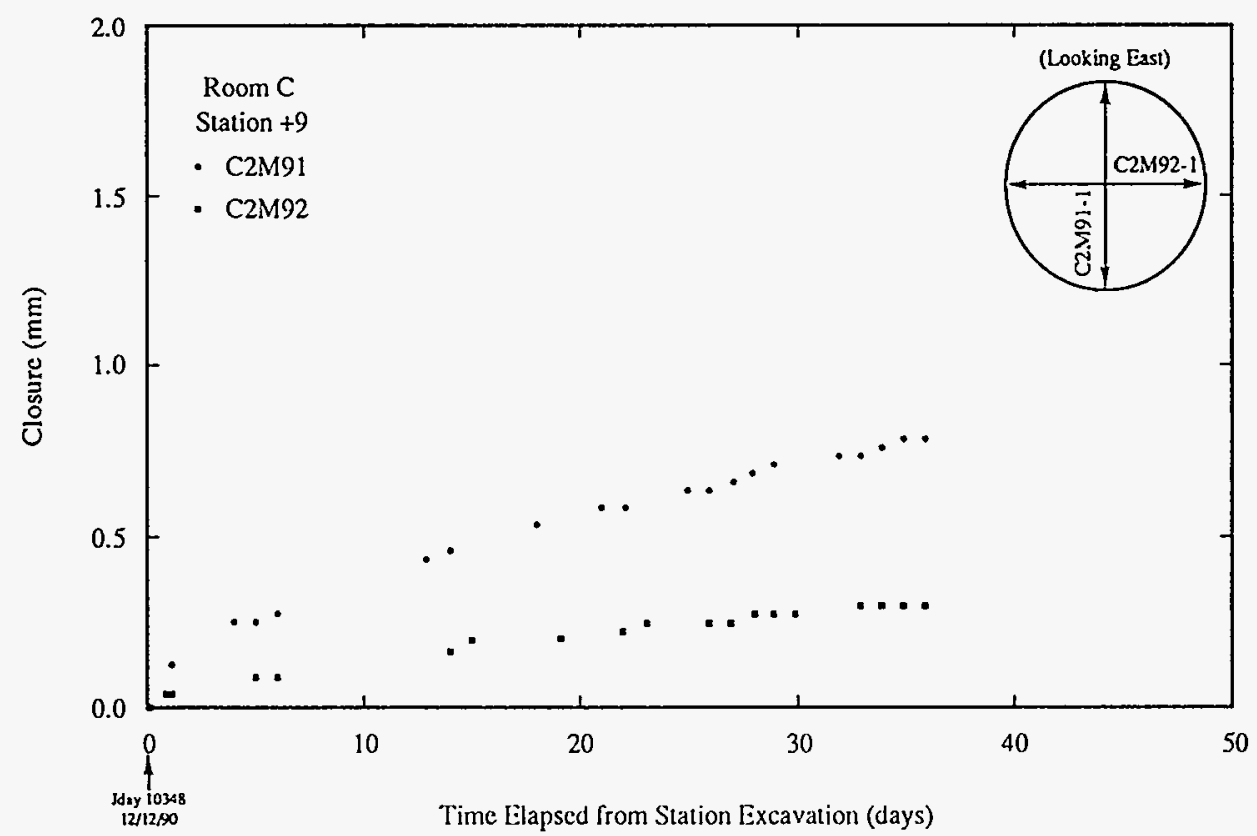

Figure 5.1.1g. Mining Sequence Gages C2M9x-x, ISBT, Station +09 m 
5.1.2 Remote Closure Measurements: A location guide for the remotely read closure gages is given in Table 5.1.3. The table shows permanent remotely read closure units that are placed vertically and horizontally inside the borehole, and the gages mounted on the surface of the pillar in Room C2. The vertical borehole closure units are designated as C22xx, with the last digit in the unit designation a "1"; and horizontal borehole closure unit designations have a "2" as the last digit. The seven pairs of units are equally spaced along the length of the borehole: one set at each end of the borehole, one set at midlength, two sets each at the third points between the ends of the borehole and the midlength.

For this test, as noted, the additional four remotely read closure units were installed on the east rib face of Room C2. Two of these units measured the vertical displacement of the rib on either side of the borehole, along parallel vertical lines separated some $1.22 \mathrm{~m}$ (4.0 ft) from the borehole center. Two similar units measured the horizontal displacement along two parallel horizontal lines separated from the borehole center by $0.61 \mathrm{~m}(2.0 \mathrm{ft})$.

Descriptions of the remotely read closure units and the reduced data are provided in Tables 5.1.4a-r. Plots of the reduced data are shown in Figures 5.1.2a-r.

Vertical and horizontal remote closure units were installed directly on the pins of the mining sequence units approximately one month after completion of the overcoring operations. The units were installed at each of the principal stations at $-9,-6,-3$, and $0 \mathrm{~m}(-30,-20,-10$, and $0 \mathrm{ft})$ as specified in the test plan and additional remote closure units not initially specified in the test plan were installed at the 3,6 , and $9 \mathrm{~m}$ $(10,20$, and $30 \mathrm{ft})$ stations. 
Table 5.1.3. ISBT Remote Closure Gages Location Guide

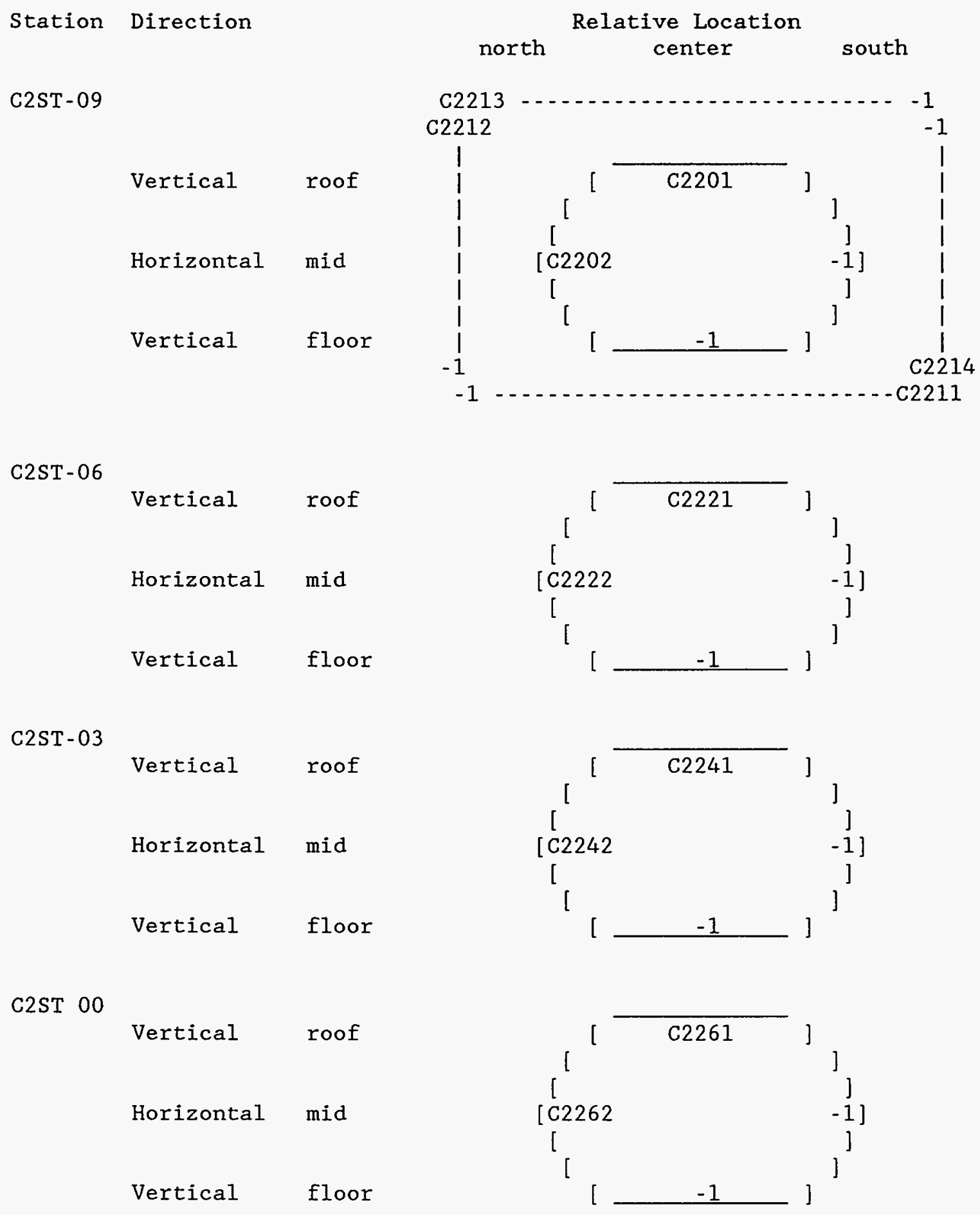


Table 5.1.3. ISBT Remote Closure Gages Location Guide (Cont.)

Station Direction

C2ST 03

$\begin{array}{lll} & \text { Vertical } & \text { roof } \\ & \text { Horizontal } & \text { mid } \\ \text { C2ST 06 } & \text { Vertical } & \text { floor } \\ & \text { Vertical } & \text { roof } \\ & \text { Horizontal } & \text { mid } \\ & & \\ & \text { Vertical } & \text { floor }\end{array}$

C2ST 09
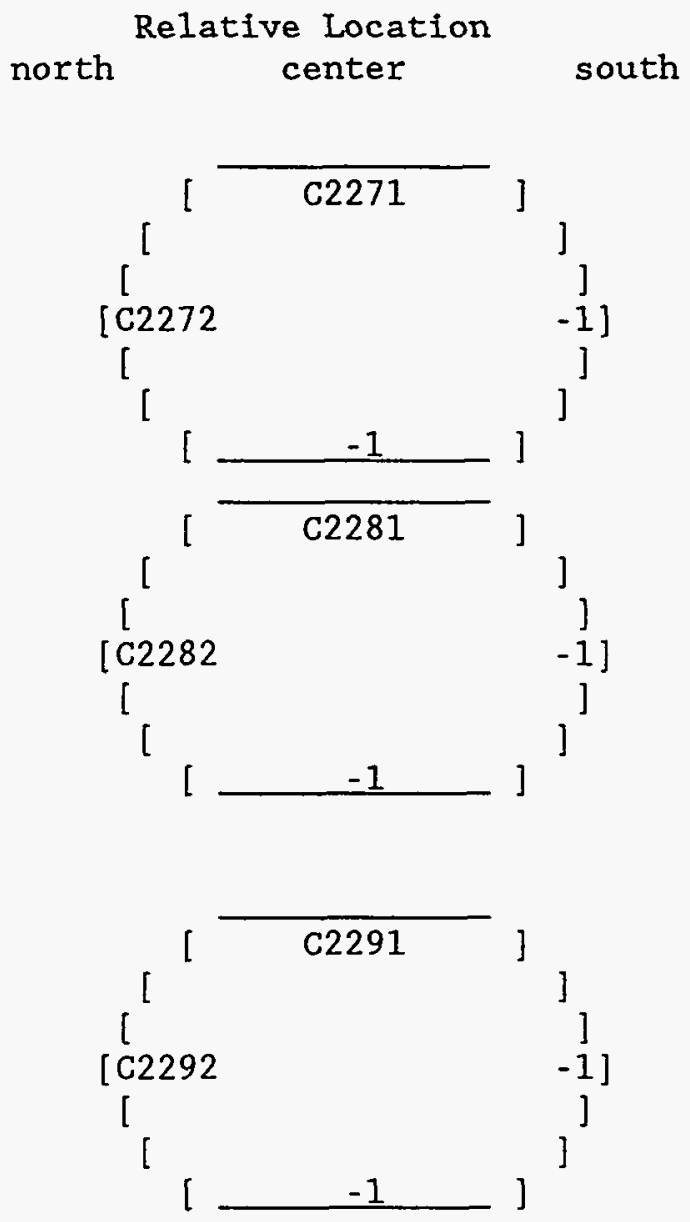

Vertical remote closure data indicates that the displacements increase in magnitude from the Room C2 rib to the center of the pillar (Principal Station 0). A similar trend is observed in the displacement data from Room $\mathrm{Cl}$ to the center of the pillar. Vertical closure measurements were approximately 258 greater in the center of the pillar compared to vertical closure at the ribs of the rooms.

Horizontal closure data indicates greater displacements at the center of the pillar (Principal Station 0) than at either of the Room C1 or C2 ribs. Horizontal closure measurements at the center of the pillar were 
considerably greater than the horizontal closure measurements at the ribs; in fact, it appears that the horizontal closure of the borehole at the Room C2 rib face is essentially zero.

Both the vertical and the horizontal closure data shows a trend of nonlinear displacement history during the early time (less than 100 days) for the data at principal stations $-3,0$ and $+3 \mathrm{~m}(-10,0$, and $10 \mathrm{ft})$. This nonlinear behavior decreases as the distance increases from the center of the pillar.

The ratio of vertical to horizontal displacement at the entrances to the borehole are in the range of 5 to 10 and show a decreasing trend to nominally 1.7 at the center of the pillar.

The rib face gages show that most of the displacement occurs in the vertical direction, with very little in the horizontal direction. This substantiates the borehole closures measured at the lip of the hole. In fact, the horizontal hole closure and the horizontal pillar surface displacements are essentially zero, indicating that the horizontal stress gradients at the pillar surface are negligible.

[text continues on page 91] 
Table 5.1.4a. Remote Closure Unit C2201

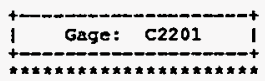

$* n * *$ C2201 PI Comments $* * * * *$

09/01/93 TLC:GTB [RANK=10] THESE DATA ARE OITSTANDING. THIS VERTICAL CLOSURE GAGE WAS INSTALLED 32 DAYS AFTER MINING OF THE INTERMEDIATE SCALE BOREHOLE.

[COMPRESION $18.50: 1$ ] (DEH)

***** C2201 Location *n***

Principal station Stat1on

Gago Gage Rec Dit Gage Coordinates

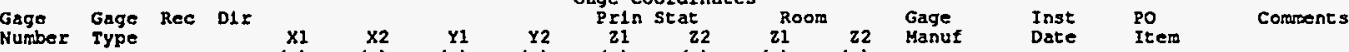

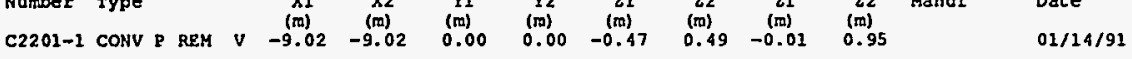

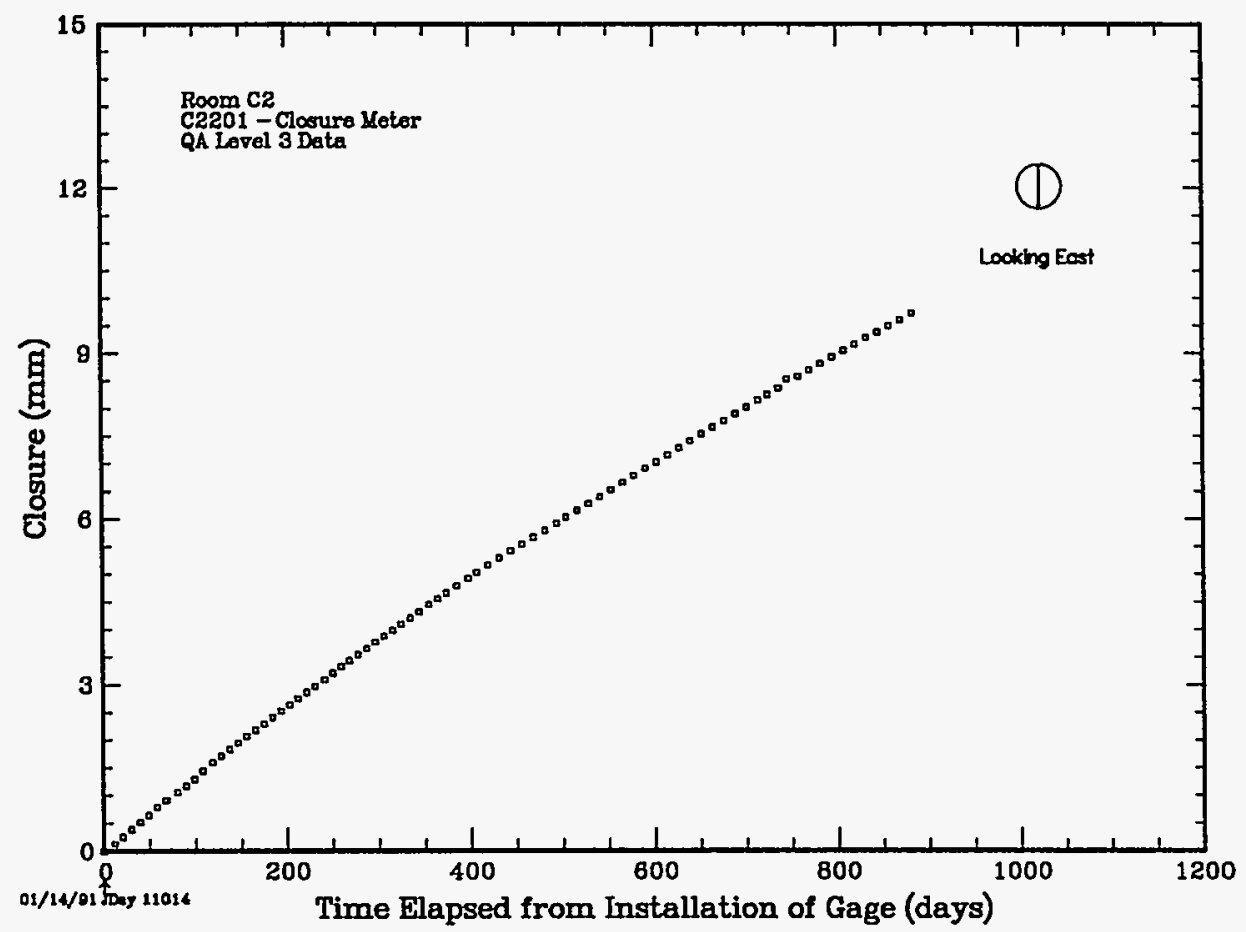

Figure 5.1.2a. Remote Closure Unit C2201 
Table 5.1.4b. Remote Closure Unit C2202

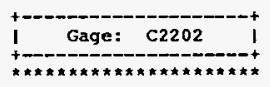

***** C2202 PI Comments $* * * \star * *$

09/01/93 TLC:GTB (RANK=10) THESE DATA ARE OUTSTANDING. THE HORIZONTAL CLOSURE

GAGE WAS INSTALLED 32 DAYS AETER MINING OF THE INTERMEDIATE SCALE BOREHOLE.

[COMPRESSION 18.50:1] (DEM]

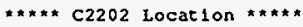

$$
\begin{aligned}
& \text { Princlpal station } \\
& \text { Station }
\end{aligned}
$$

Gage coordinates

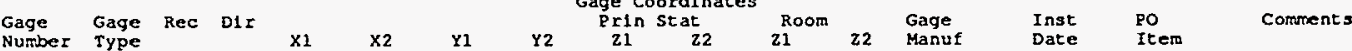

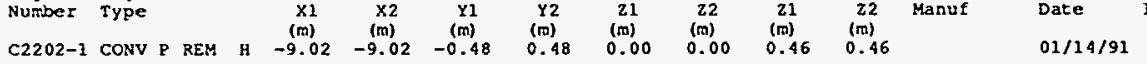

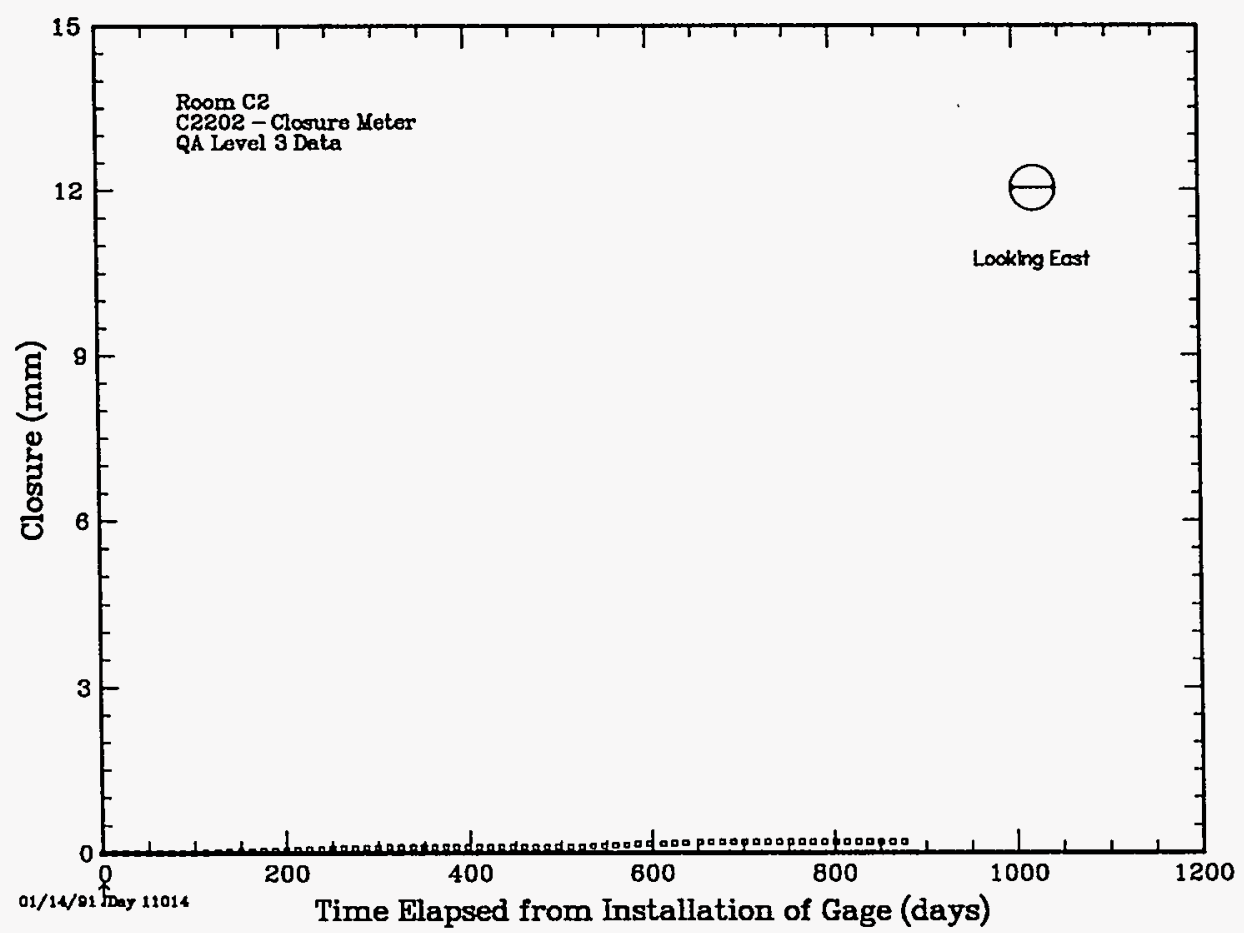

Figure 5.1.2b. Remote Closure Unit C2202 
Table 5.1.4c. Remote Closure Unit C2211

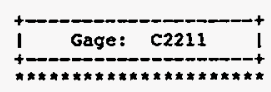

\#*** C2211 2 I Compents $* * a * *$

09/02/93 TLC: GTB [RANK=9] THESE DATA ARE EXCEPTIONAL. THIS HORIZONTAL CLOSURE HAS INSTALLED ON THE RIB FACE 308 DAYS BEFORE MINING OF THE INTERMEDIATE 17 BOREHOLE. THE GAGE WAS DISTURBED IHICE. THE FIRST DISTURBANCE OCCURRED AT 171 DAYS (JULIAN DATE 10200 ) DURING THE ROOM C2 ROOF BOLTING. A SECOND DISTURBANCE DAYS (JULTAN DATE 10332)

A NEW GAGE WAS INSTALLED AT 325 DAYS. [COMPRESSION 17.85:1] (DEM)
[1

***** C2211 Location *****

Princlpal station

Station

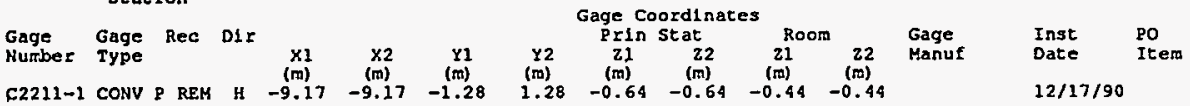

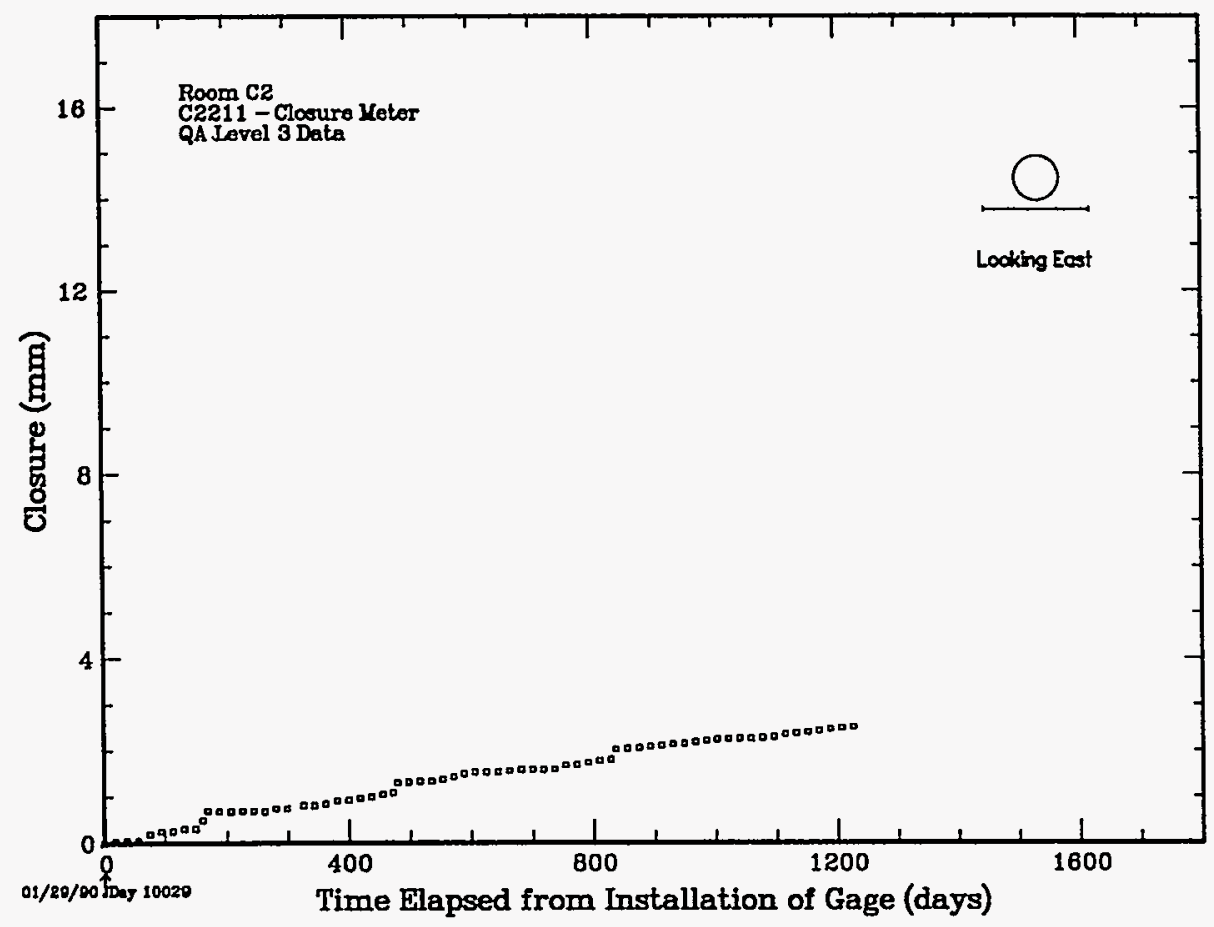

Figure 5.1.2c. Remote Closure Unit C2211 
Table 5.1.4d. Remote Closure Unit C2212

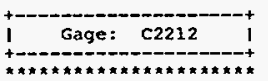

****. C2212 PI Coments *****

09/02/93 TLC:GTB (RANK=9] THESE DATA ARE EXCEPTIONAL. THIS VERTICAL CLOSURE GAGE WAS INSTALLED ON THE RIB FACE 308 DAYS BEFORE MINING OF THE INTERMED IAT SCALE BORE THE GAGE WAS DISTURBED AT 221 DAYS (JULIAN DATE 10250) AND

JUST PRIOR TO THE FIRST DAY
[COMPRESSION $17.98: 1]$ (DEM]

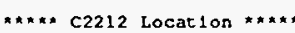

Principal station

Station

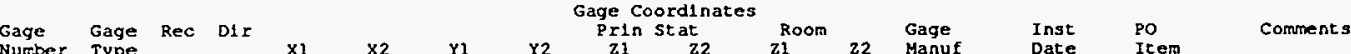

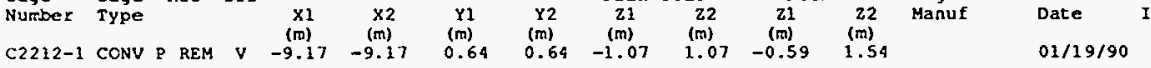

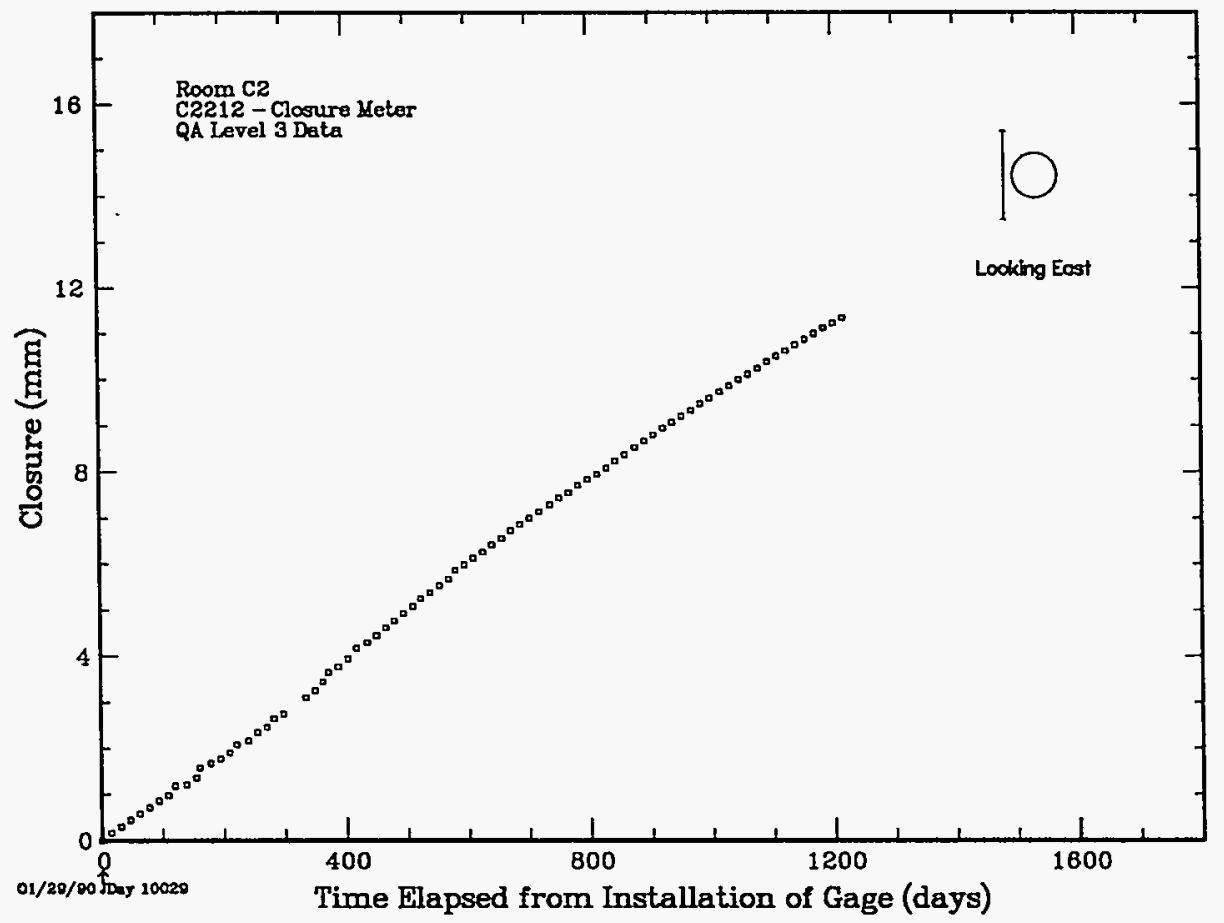

Figure 5.1.2d. Remote Closure Unit C2212 
Table 5.1.4e. Remote Closure Unit C2213

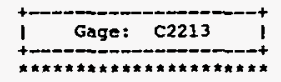

n**A* C2213 PI Coments $* * * * *$

09/02/93 TLC:GTB (RANK=8) THESE DATA ARE EXCELLENT. THIS HORIZONTAL CLOSURE GAGE WAS INSTALLED ON THE RIB FACE 308 DAYS BEFORE MINING OF THE INTERMEDIATE SCALE BOREHOLE. THE GAGE WAS DISTURAED AT 133 DAYS (JULIAN DATE 10162 ) JUST PRIOR TO THE BOLTING OE THE C2 ROOF, AI 218 DAYS (JULIAN DATE 10247), AND AT
307 DAYS THE START OF THE MINING OF THE BOREHOLE. (COMPRESSYON 18.21:1] (DEM)

***** C2213 Location $* * \star * *$ Principal station
Station

Gage Gage Ree Dir

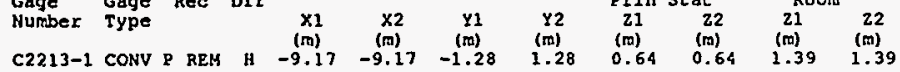

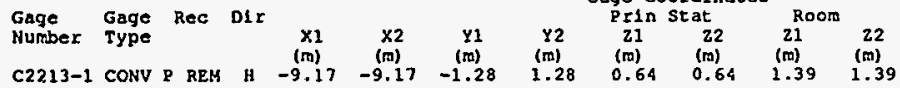

Gage Coozdinates

$\begin{array}{lll}\text { Gage } & \text { Inst } & \text { Po } \\ \text { Manuf } & \text { Date } & \text { Item }\end{array}$

Coments

$01 / 19 / 90$

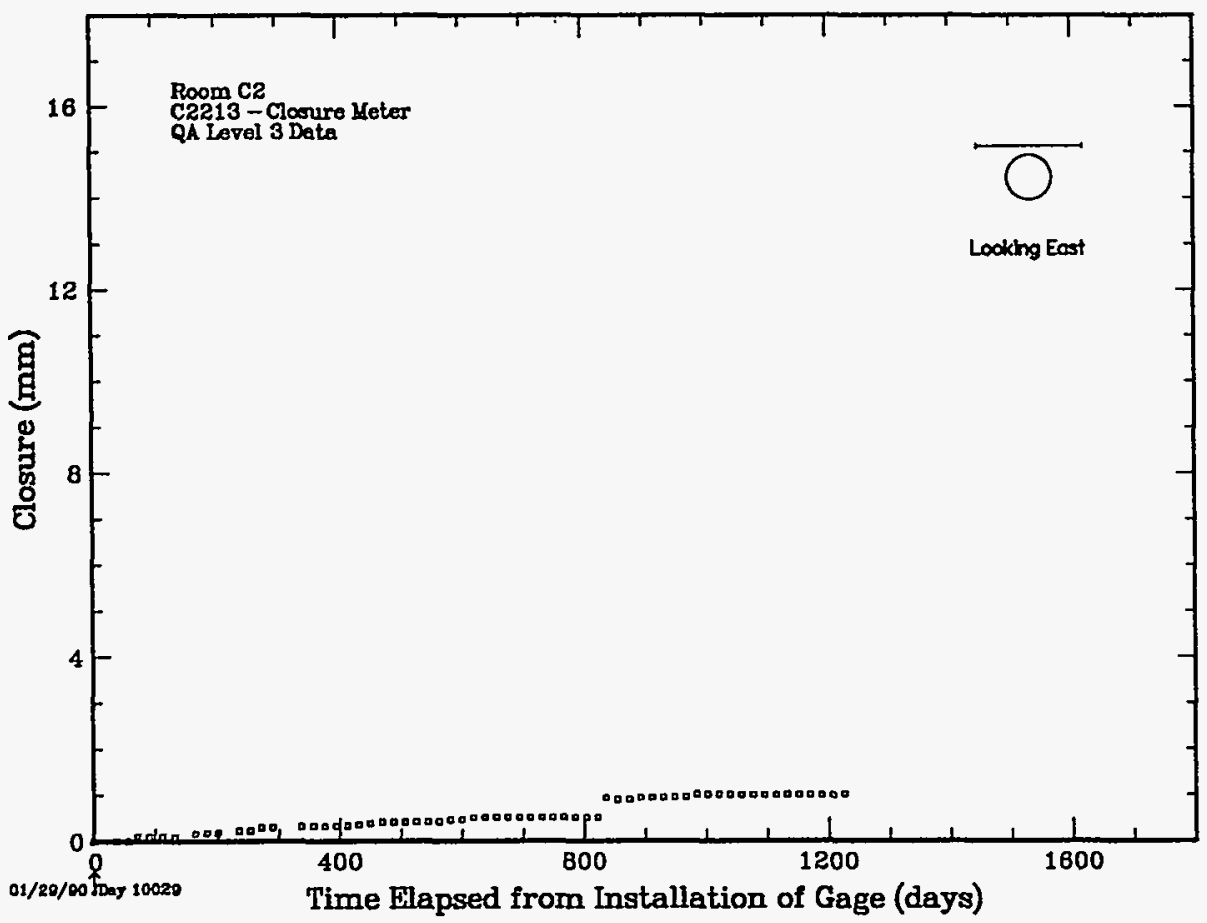

Figure 5.1.2e. Remote Closure Unit C2213 
Table 5.1.4f. Remote Closure Unit C2214

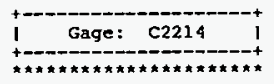

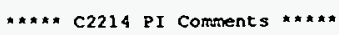

09/02/93 TLC: GTB [RANK=10] THESE DATA ARE CUTSTANDING. THIS VERTICAL CLOSURE SCALE BOREHOLE. THE GAGE OIEO AFTER 37 DAYS (JULIAN DATE 10066) AND A NEW GAGE INSTALLED AT OAY 148 (JULIAN DATE 10177). RECALIBRATION OF THAT GAGE $O$ CCURRED AT DAY 242 (JULIAN DATE 10271). THE THO RAPID RISES SHOSN BY THE DATA AT DAYS

THE TRO RAPID RISES SHCMN BY THE DATA aT DaYS

THE INTERMEDIATE BOREHOLE, RESPECTIVELY. [COMPRESSION 16.57:1] (DEM)

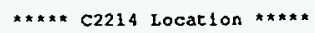
Principal station

Gage Rec Dir Gage Coordinates

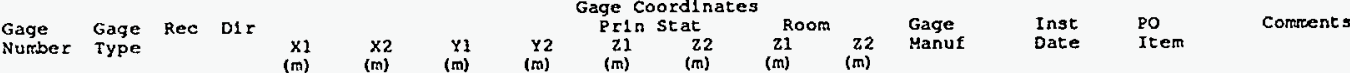

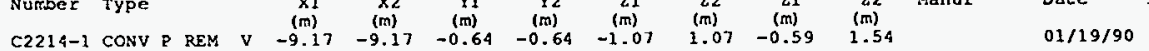

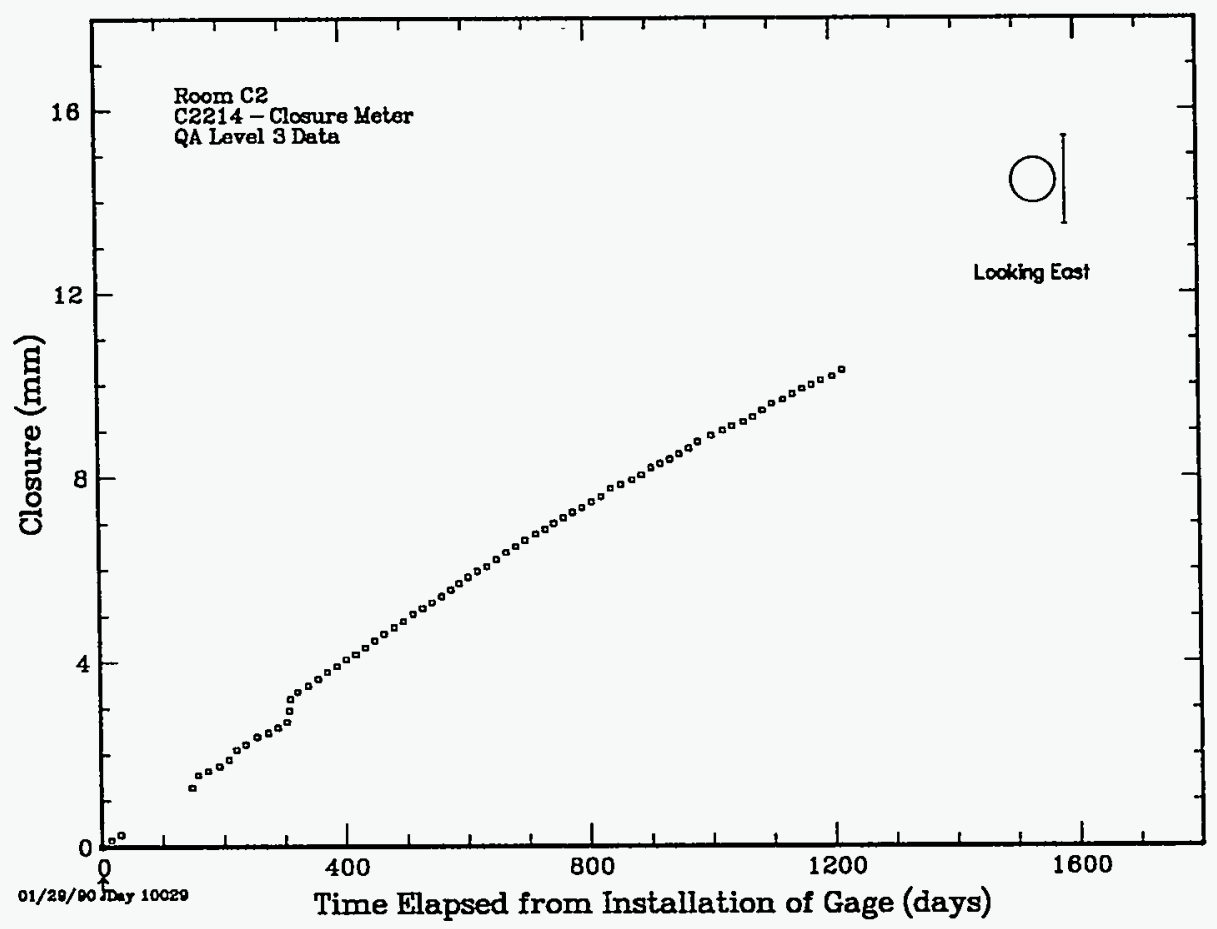

Figure 5.1.2f. Remote Closure Unit C2214 
Table 5.1.4g. Remote Closure Unit C2221

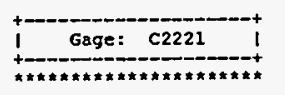

*\#*** C2221 PI Comments *****

09/01/93 TLC:GTB [RANK=10] THESE DATA ARE OUTSTANDING. THIS VERTICAL CLOSURE GAGE WAS INSTALLED 32 DAYS AFTER MINING OF THE INTERMEDIATE SCALE BOREHOLE. GAGE WAS INSTALLED 32 DAYS AF
[COMPRESSION $18.50: 1$ (DEM)

a**** C2221 Location *n***

Princlpal station

station

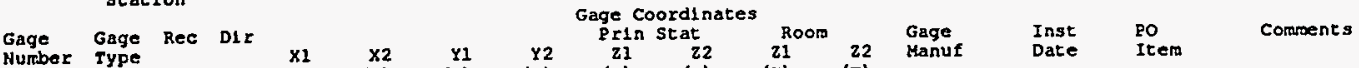

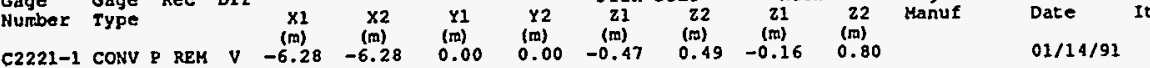

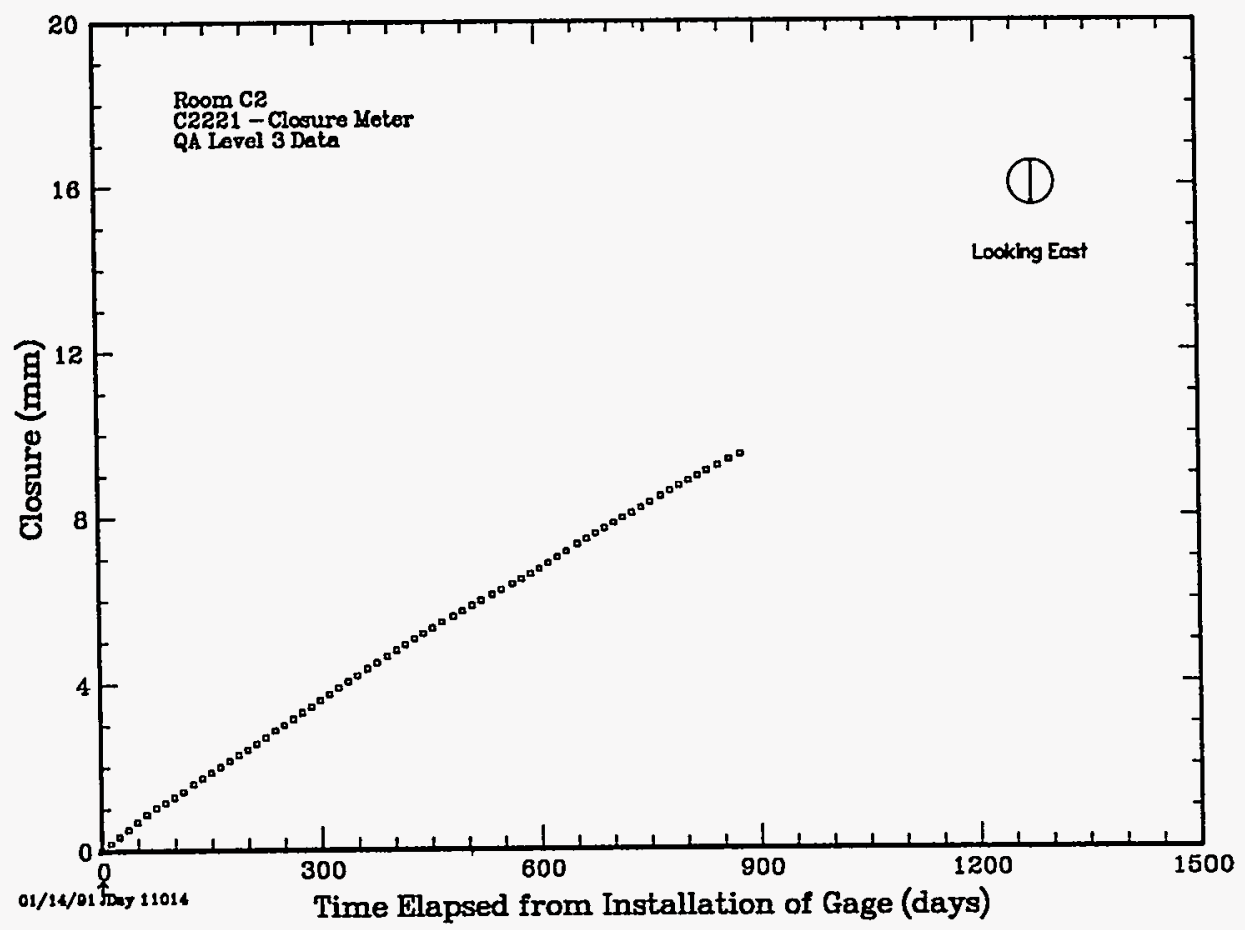

Figure 5.1.2g. Remote Closure Unit C2221 
Table 5.1.4h. Remote Closure Unit C2222

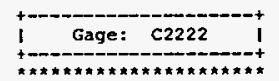

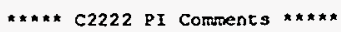

09/01/93 TLC:DEM:GTB [RANK=10] THE DATA ARE OUTSTANDING. THIS HORIZONTAL CLOSURE GAGE WAS INSTALLED 32 DAYS AFTER MINING OF THE INTERMEDIATE SCALE BOREHOLE. [COMPRESSION $18.50: 1$ ] (DEM)

$* * * * *$ C2222 Location $* * * * *$

\section{Principal station}

Station

Gage Coordinates

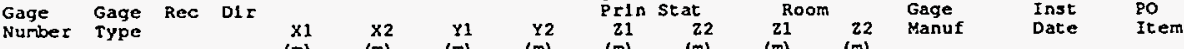

$\begin{array}{lllllllllll} & & (m) & (m) & (m) & (m) & (m) & (m) & (m) & (m) & \\ \text { C2222-1 CONV P REM H } & -6.28 & -6.28 & -0.48 & 0.48 & 0.01 & 0.01 & 0.32 & 0.32 & & 01 / 14 / 91\end{array}$

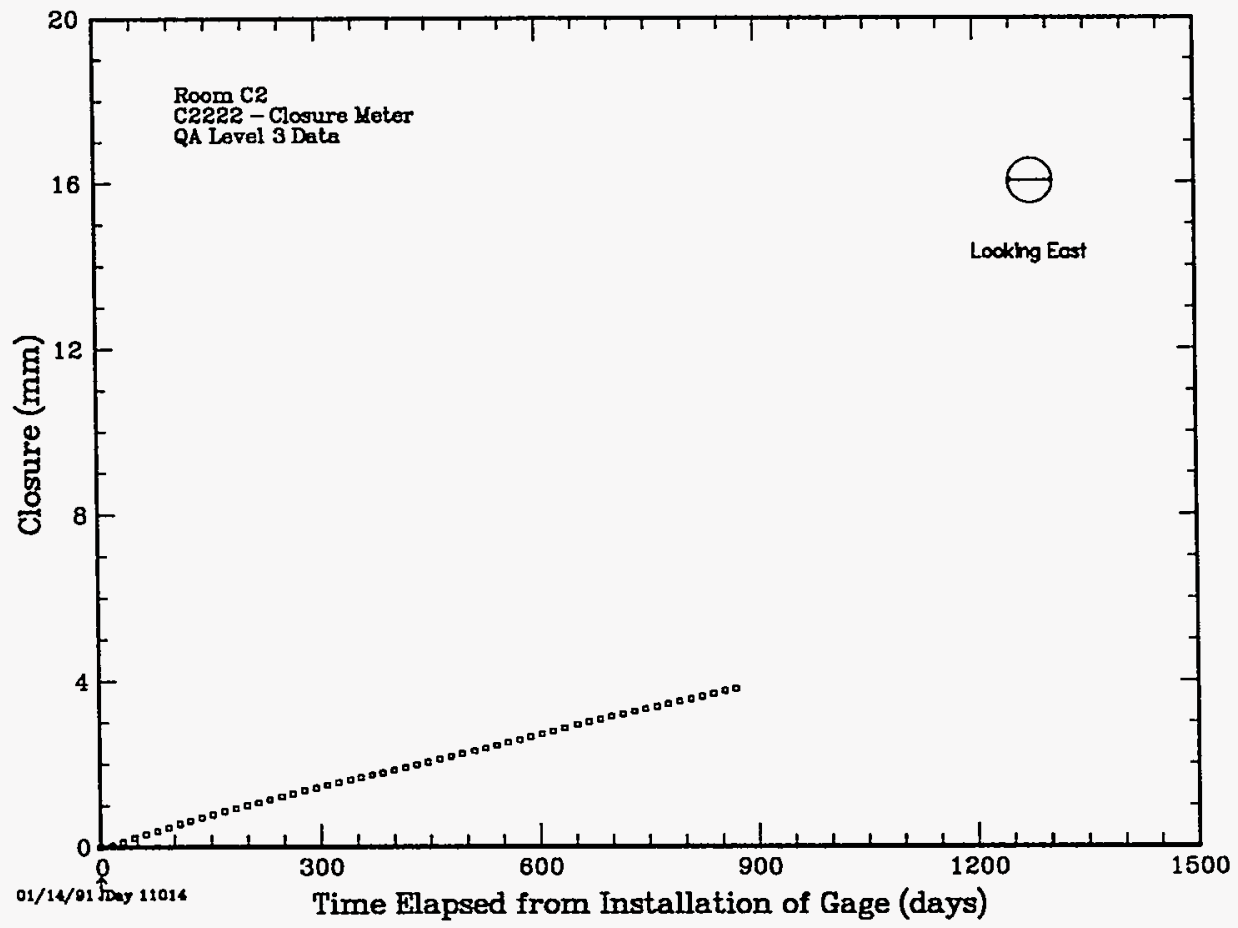

Figure 5.1.2h. Remote Closure Unit C2222 
Table 5.1.4i. Remote Closure Unit C2241.

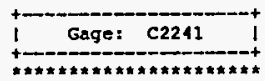

***** C2241 PI Compents ****"

09/01/93 ILC:GTB [RANK=10] THESE DATA ARE OISTANDING. THIS VERTICAL CLOSURE GAGE WAS INSTALLED 29 DAYS AFTER MINING OF THE INTERMEDIATE SCALE BOREHOLE. [COMPRESSION $17.02: 11$ (DEM)

A*A* C2241 Location *k***

Principal station Station

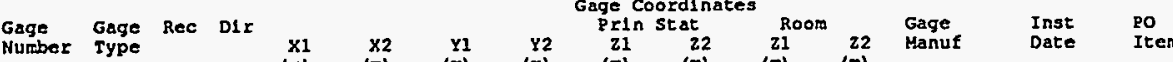
$01 / 10 / 91$

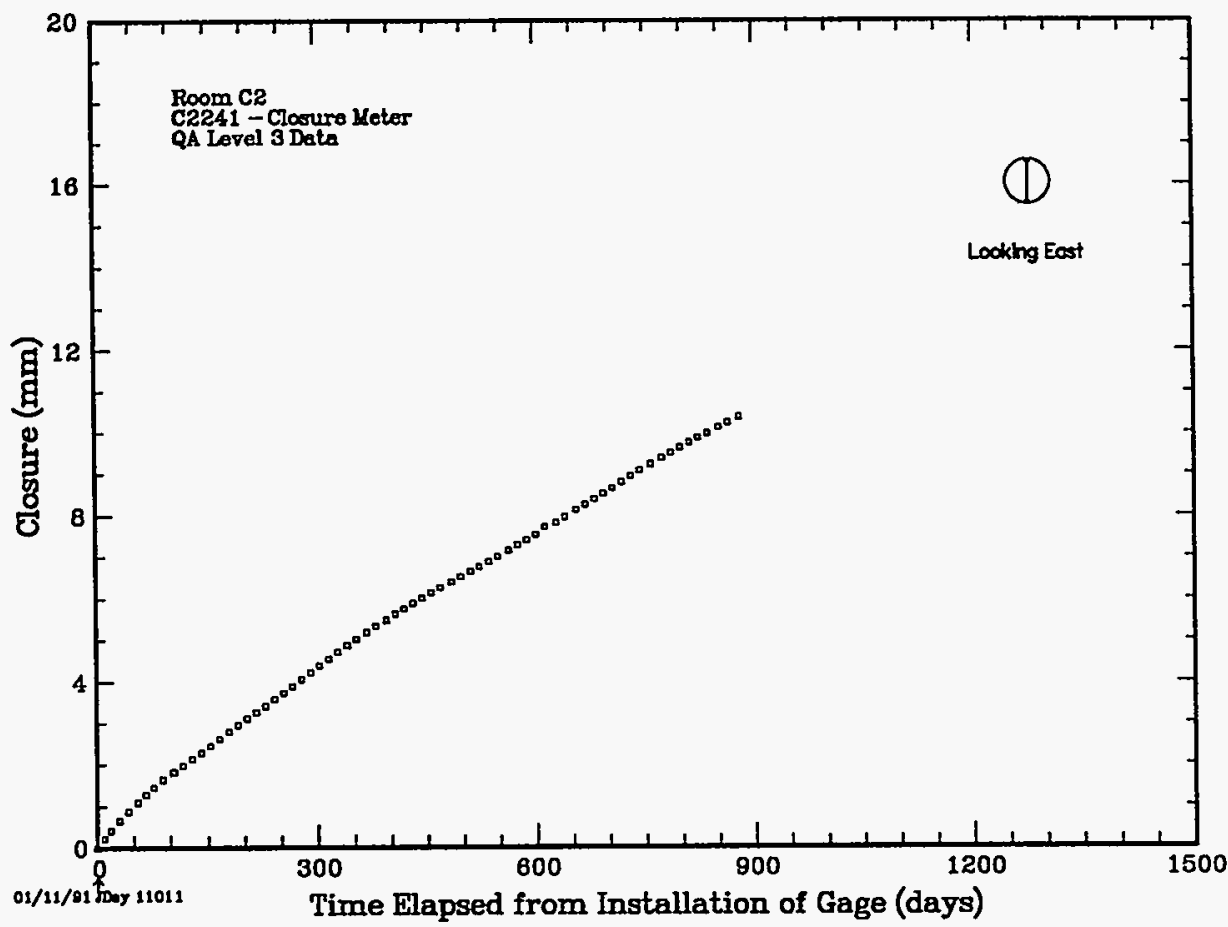

Figure 5.1.2i. Remote Closure Unit C2241 
Table 5.1.4j. Remote Closure Unit C2242

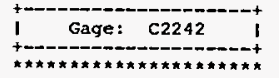

***** C2242 PI Comments $* * * * *$

09/01/93 TLC:GTB [RANK=10] THESE DATA ARE CUTSTANDING. THIS HORIZONTAL CLOSURE GAGE WAS INSTALLED 29 DAYS AFTER MINING OE THE INTERMEDIATE SCALE BOREHOLE. ICOMPRESSION 17.02:1]
(DEM)

***** C2242 Location *****

\section{Principal station} Station

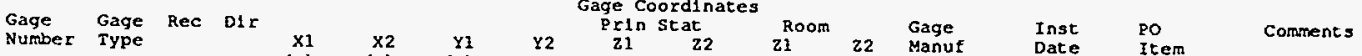

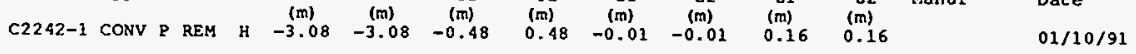

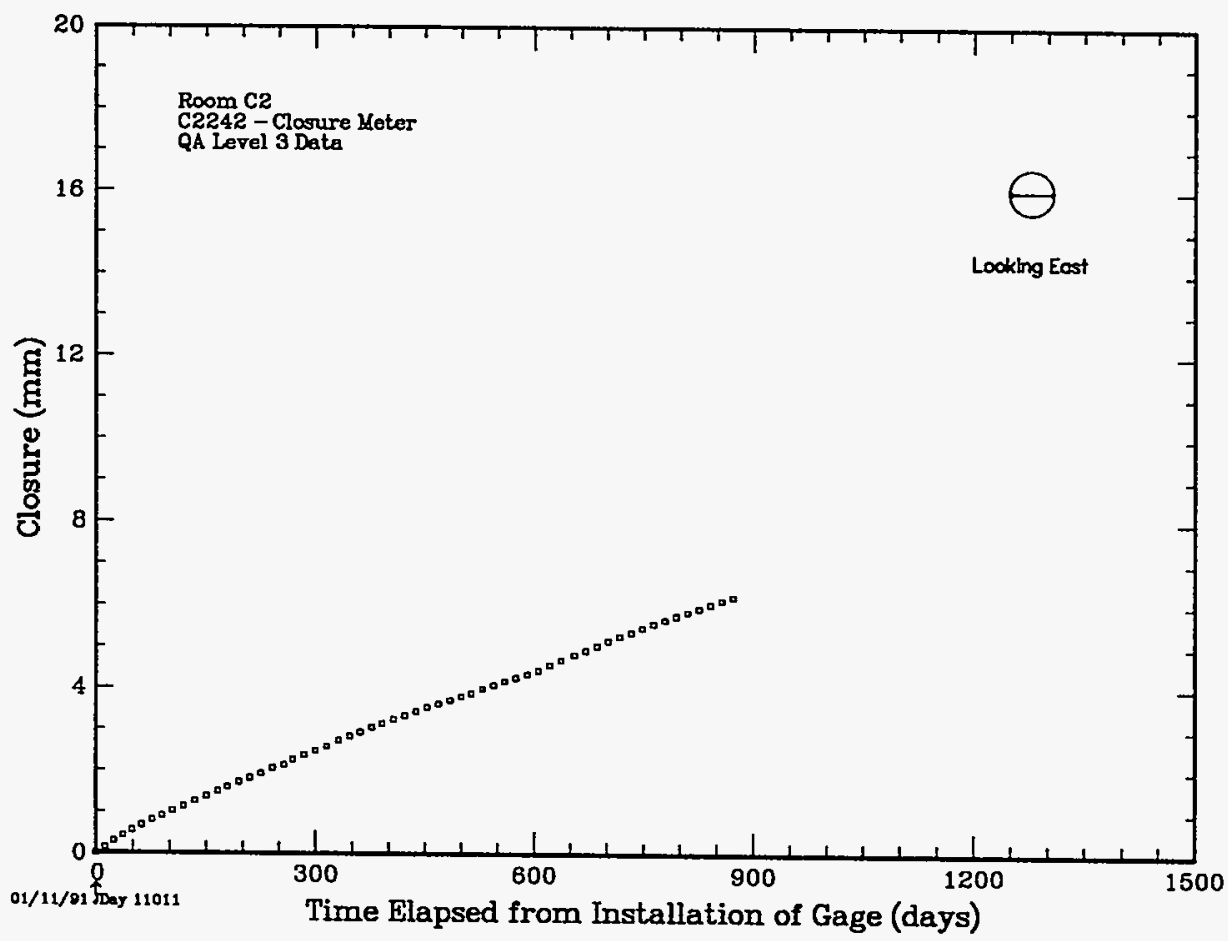

Figure 5.1.2j. Remote Closure Unit C2242 
Table 5.1.4k. Remote Closure Unit C2261

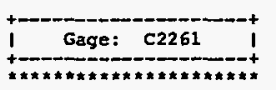

*k*** C2261 PI Comrents *****

09/01/93 TLC:GTB (RANK=10) THESE DATA ARE OUTSTANDING. THIS VERTICAL ClOSURE GAGE WAS INSTALLED 14 DAYS AFTER MINING OF THE INTERMEDIATE SCALE BOREHOLE.

[COMPRESSION 18.49:1] (ORM)

***** C2261 Lecation *****

Principal station

station

Gage Gage Rec D1r

Gage Coordinates

$\begin{array}{cccccccccc} & & X 1 & X 2 & Y 1 & Y 2 & 21 & 22 & 21 & 22 \\ \text { C2261-1 CONV P REM } & V & -0.04 & -(m) & (m) & (m) & (m) & (m) & (m) & (m) \\ (m) & -0.04 & 0.00 & 0.00 & -0.48 & 0.48 & -0.48 & 0.48\end{array}$

$\begin{array}{lll}\text { Gage } & \text { Inst } & \text { go } \\ \text { Manuf } & \text { Date } & \text { Itern }\end{array}$

Coments

Con 1

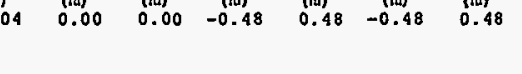

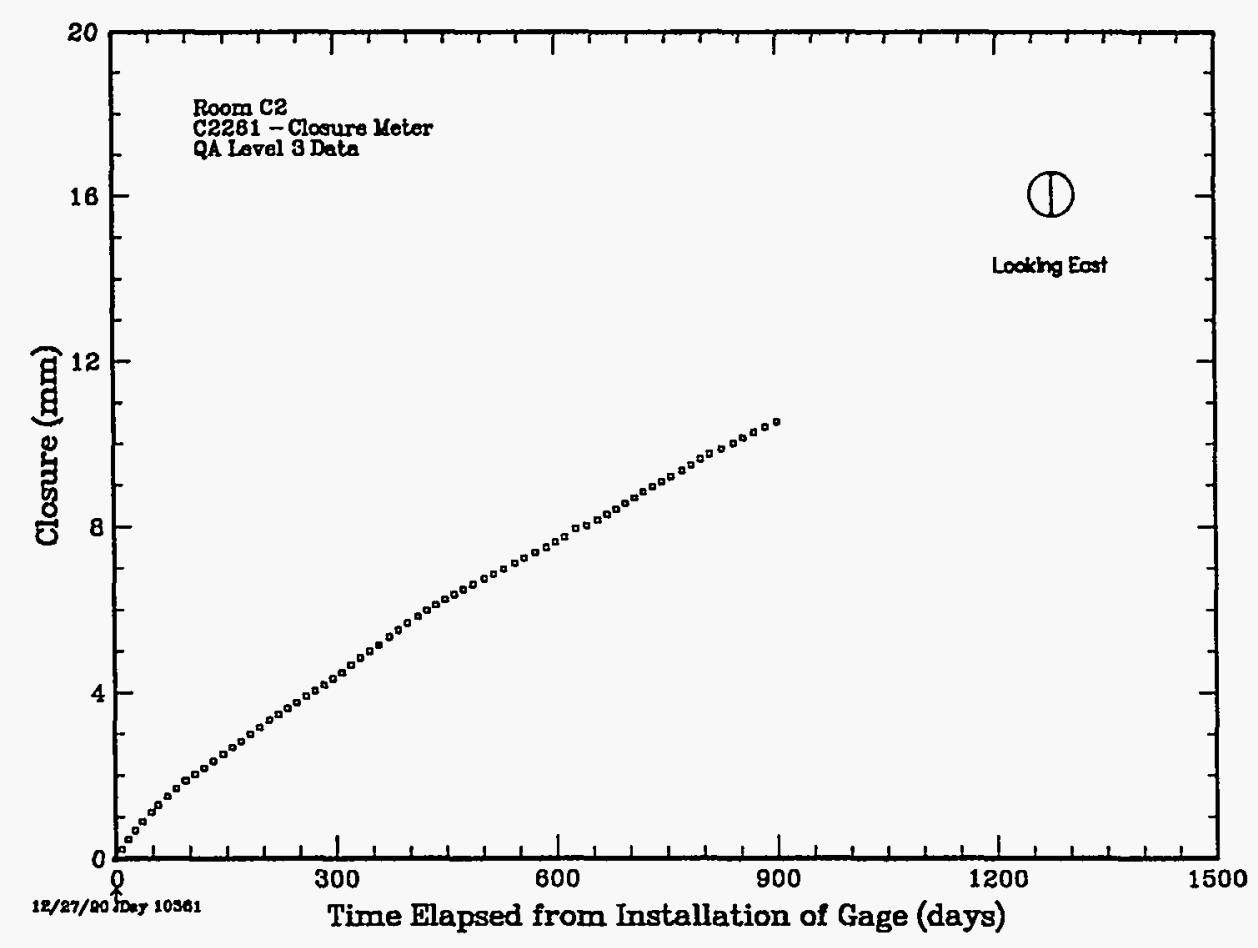

Figure 5.1.2k. Remote Closure Unit C2261 
Table 5.1.41. Remote Closure Unit C2262

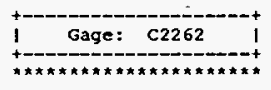

*A*** C2262 PI Comments *****

09/01/93 TLC: GTB (RANK=10) THE DATA ARE OUTSTANDING. THIS HORIZONTAL CLOSURE GAGE WAS INSTALLED 14 DAYS AFTER MINING OF THE INTERMEDIATE SCALE BOREHOL'.

GAGE WAS INSTALLED 14 DAYS AFTE
[COMPRESSION $18.49: 1]$ (DEM)

$* * * \star *$ C2262 Location $* * * * *$

Principal station

St at 1 on

Gage Gage Rec DIx Gage Coordinates

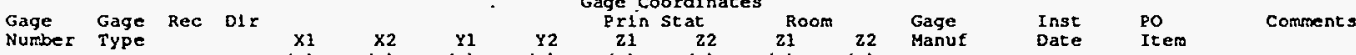

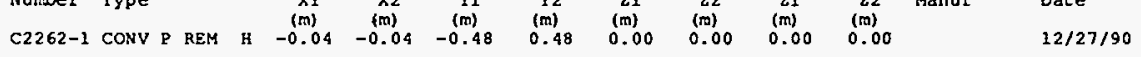

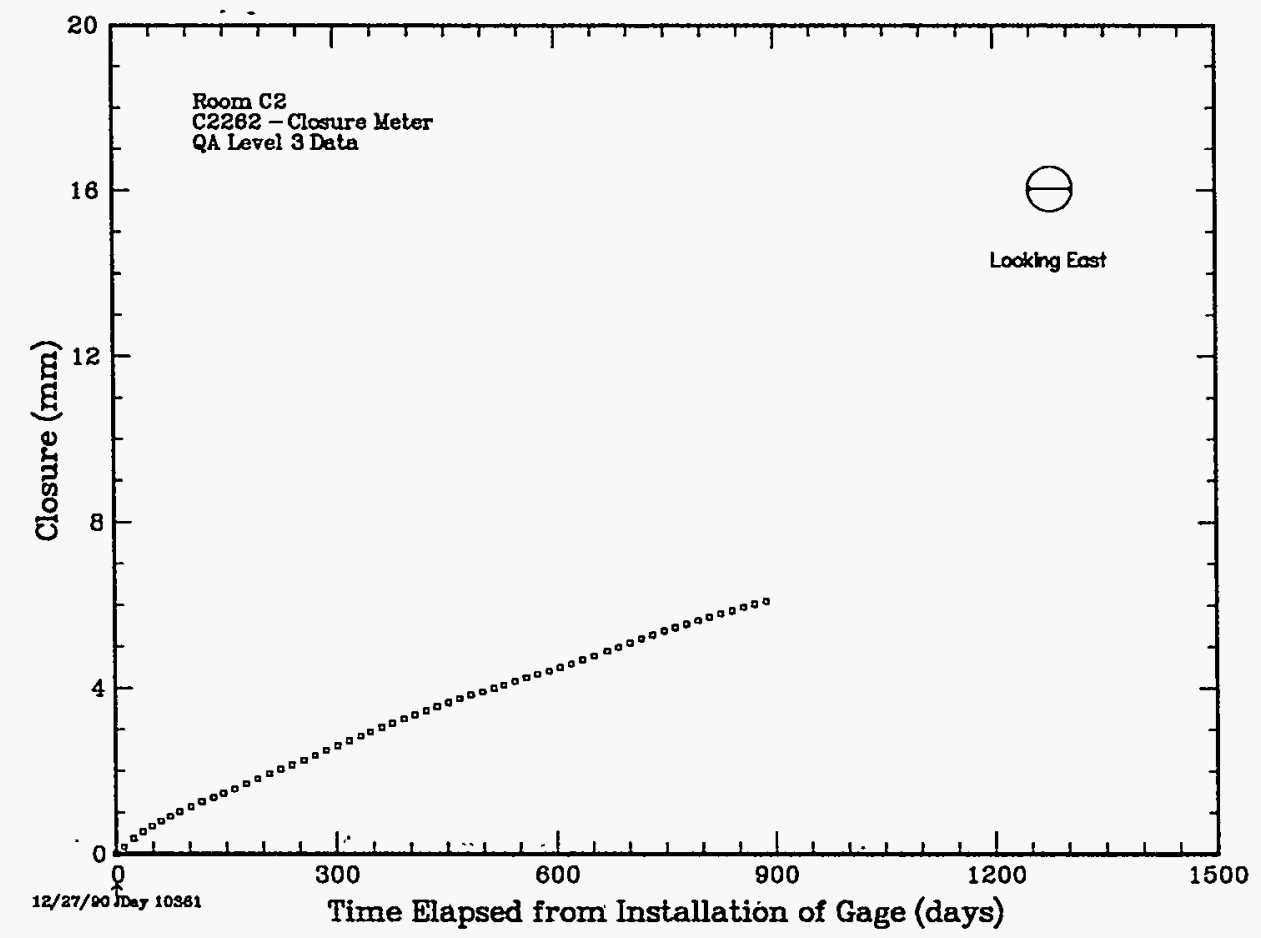

Figure 5.1.21. Remote Closure Unit C2262 
Table 5.1.4m. Remote Closure Unit C2271

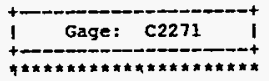

\#*** C2271 PI Comments *****

09/01/93 TLC:GTB [RANK=10] THESE DATA ARE OUTSTANDING. THIS VERTICAL CLOSURE GAGE WAS IHISTALLE 36 DAYS AFTER MINING OF THE INTERMEDIATE SCALE BOREHOLE. [COMPRESSION 18.61:1] (DEM)

A*A** C2271 Location *n**** Principal station Station

Gage Coordinatẹs

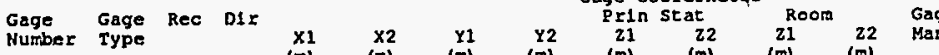

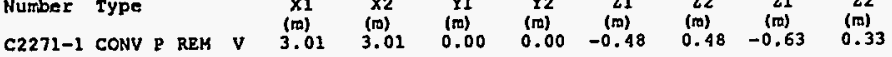

$\begin{array}{lll}\text { Inst } & \text { Po } \\ \text { Manuf } & \text { Date } & \text { Item }\end{array}$

$01 / 17 / 91$

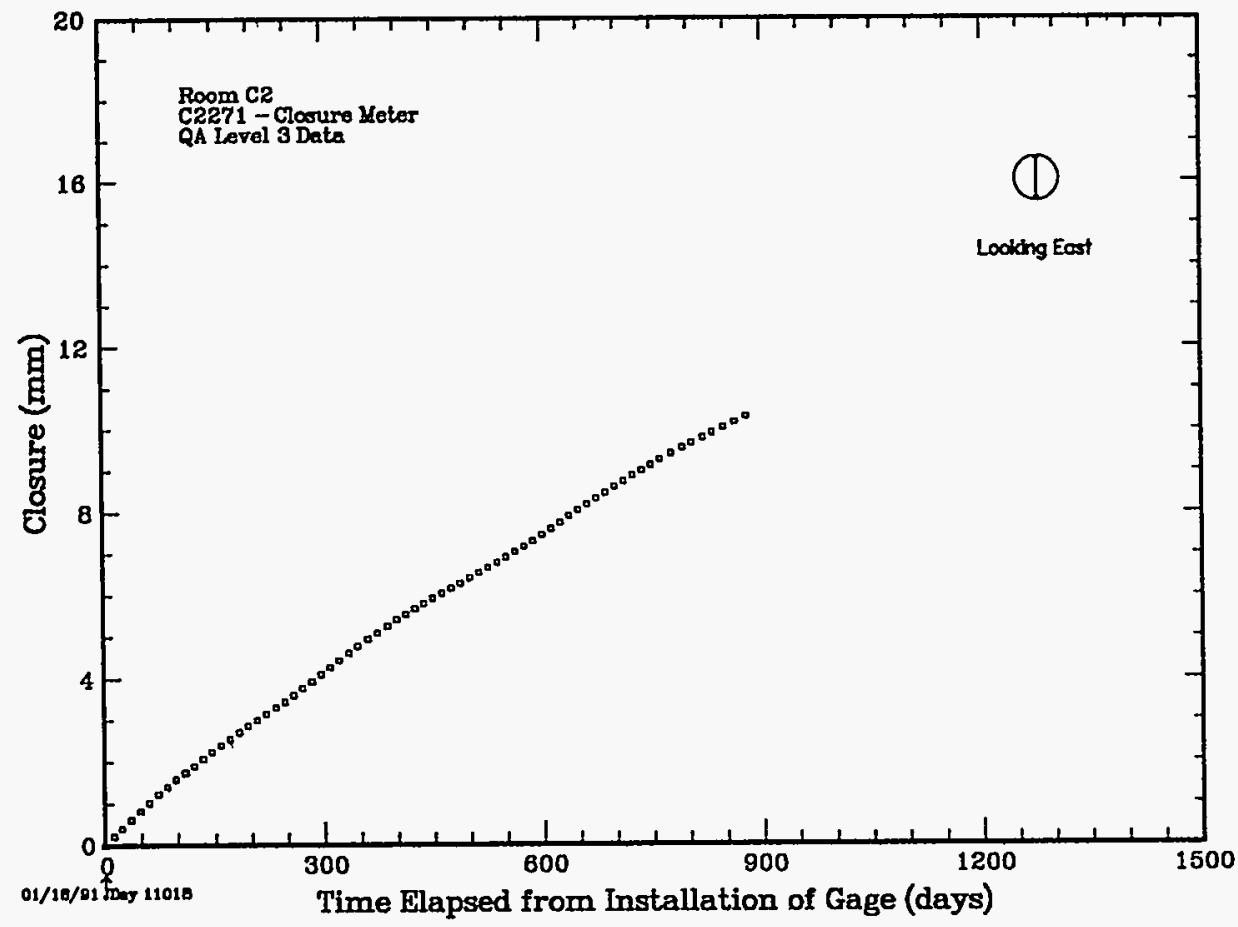

Figure 5.1.2m. Remote Closure Unit C2271 
Table 5.1.4n. Remote Closure Unit C2272

$\left.\right|_{\text {t) Gage: C2272 }} ^{+--}$

* *.** c2272 PI Comments $*$ ****

09/01/93 TLC:GTB (RANK=10) THE DATA ARE OUTSTANDING. THIS HORIZONTAL CLOSURE (COMPRESSION 18.61:1] DAYS AFTER MINING OF THE INTERMEDIA

$\star \star \star \star \star *$ C2272 Location $\star * \star \star * *$

Principal station

Station

Gage Gage coordinates

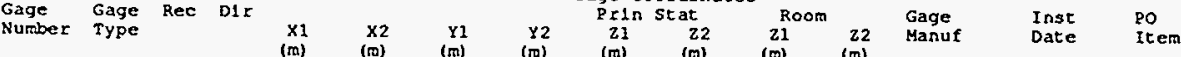

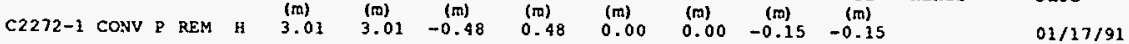

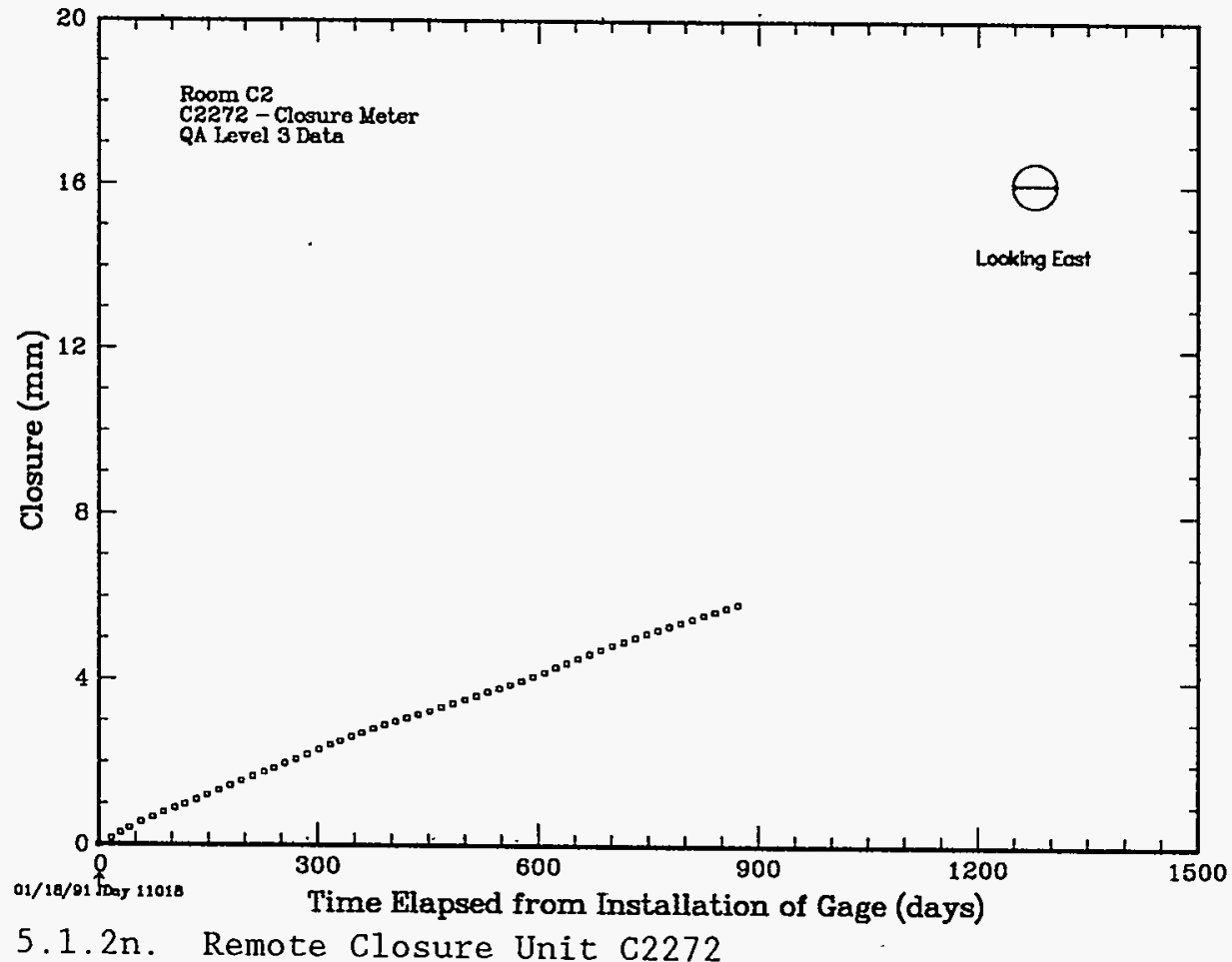

Figure 5.1.2n. Remote Closure Unit C2272 
Table 5.1.40. Remote Closure Unit C2281

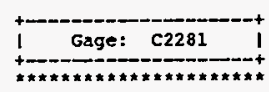

HA*** C2281 PI Comments $* * * * *$

09/01/93 ILC:GTB (RANK=10] THESE DATA ARE OUTSTANOING. THIS VERTICAL CLOSUR GAGE HAS INSTALLED 36 DAYS AFTER MINING OF THE INTERMEDIATE SCALE BOREHOLE.

[COMPRESSION 18.55:1] (DEM)

A*** C2281 Location \#****

Principal station

Station Gage Coordinates

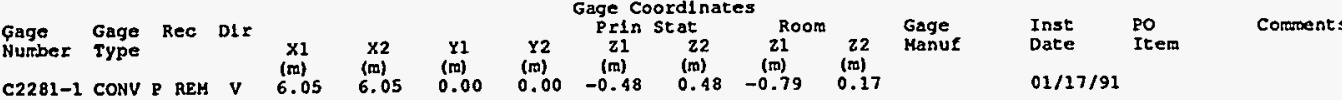

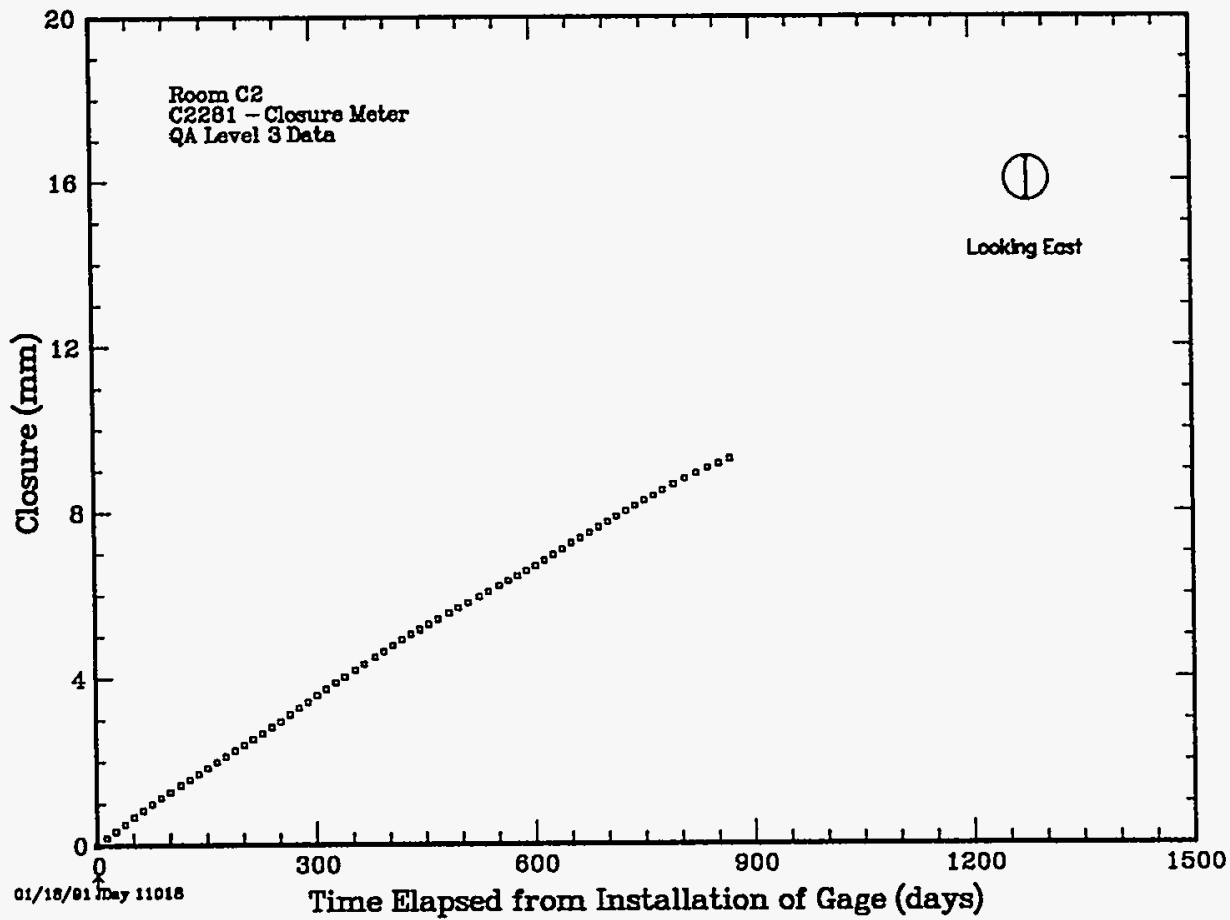

Figure 5.1.20. Remote Closure Unit C2281 
Table 5.1.4p. Remote Closure Unit C2282

\begin{tabular}{|c|c|c|}
\hline 1 & Gage: & $C 2282$ \\
\hline
\end{tabular}

***** C2282 PI Comments $* * * * *$

09/02/93 TLC:DEM:GTB [RANK=10] THESE DATA ARE CUTSTANDING. THIS HORIZONTAL,

CLOSURE TLC: WAS:GTB

:1) (DEM)

***** C2282 Location *n***

Principal station

Station

Gage Gage Rec $D 15$ Gage Coordinates

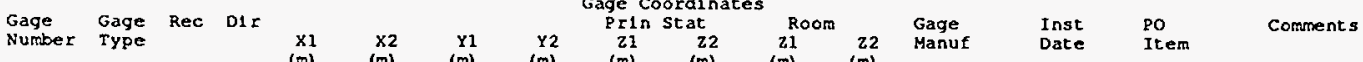

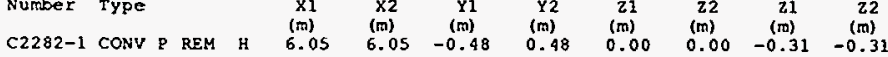

$01 / 17 / 91$

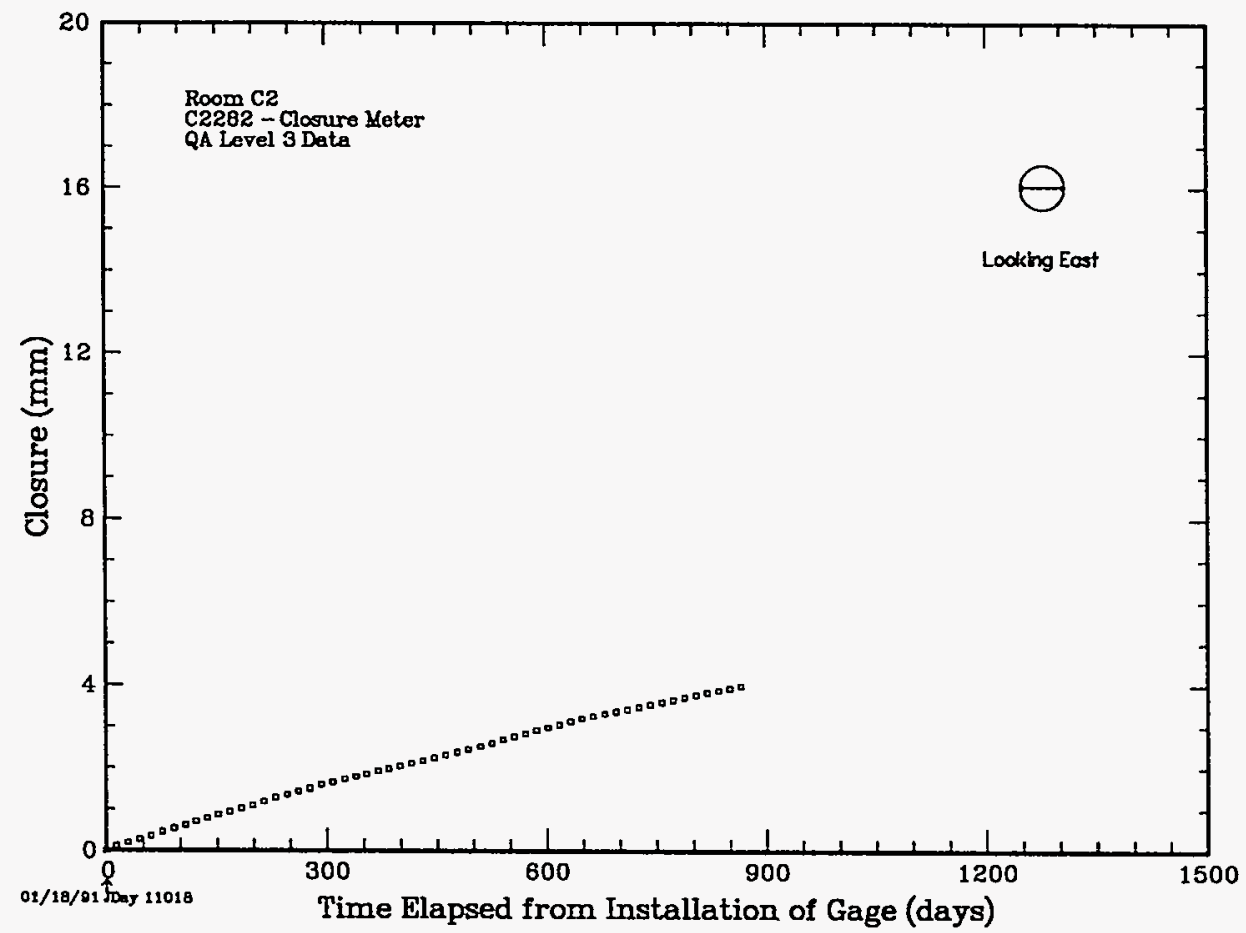

Figure 5.1.2p. Remote Closure Unit C2282 
Table 5.1.4q. Remote Closure Unit C2291

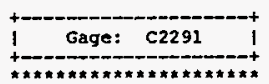

$* * * *$ C2291 PI Coraments $* * * * *$

09/02/93 TLC:GTB [RANK=101 THESE DATA ARE OUTSTANOTNG. THIS VERTICAL CLOSURE GAGR GAS INSTALLED 36 DAYS AFTER MTNING OF IHE INTERHEDIATE SCALE BOREHOLE. (COHPRESSION $18.61 ; 1$ ] (DEM)

***** C2291 Location *****

Principal station
Seation

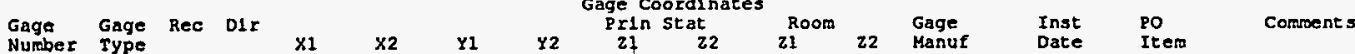

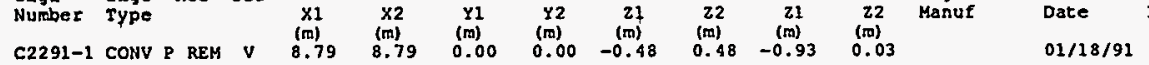

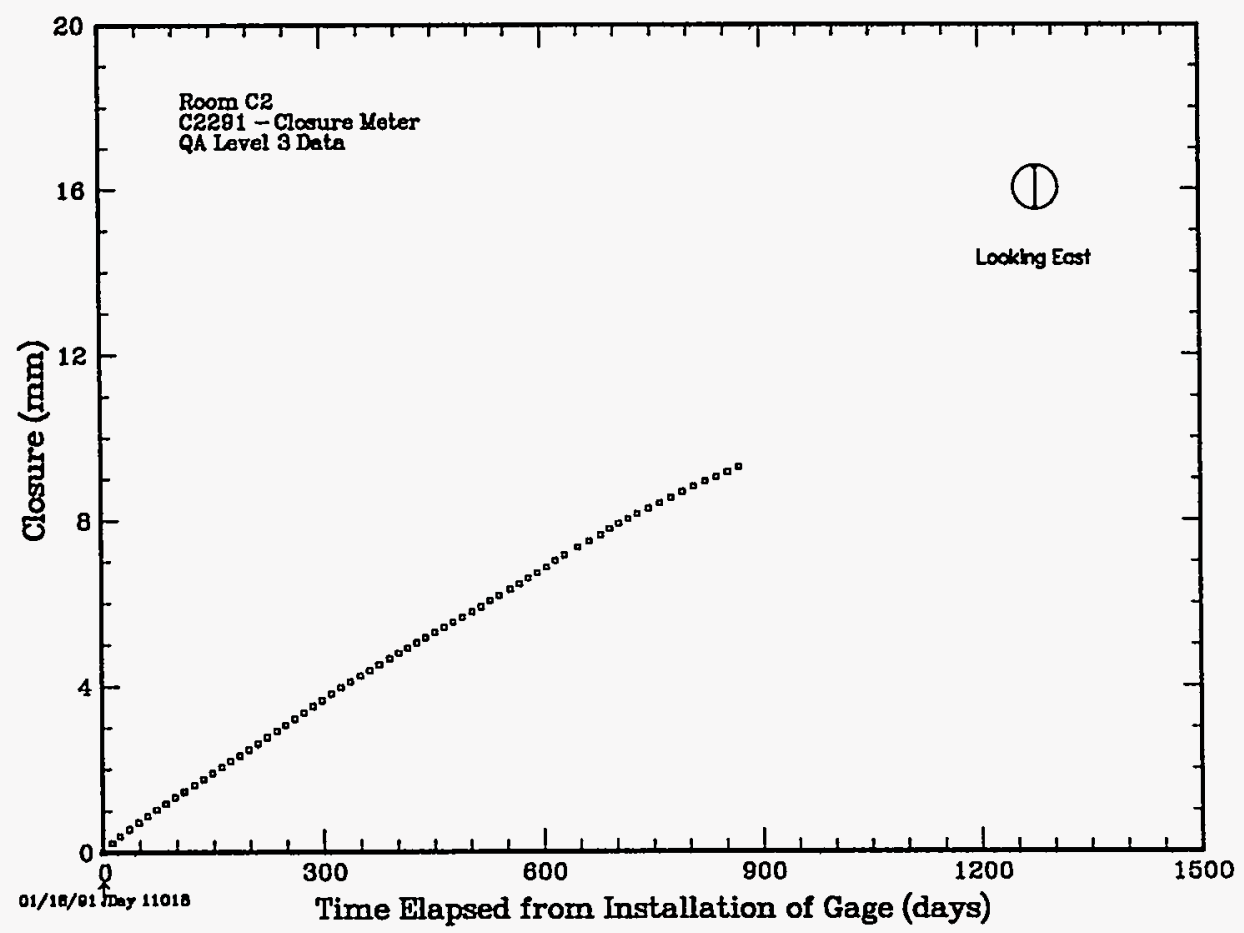

Figure 5.1.2q. Remote Closure Unit C2291 
Table 5.1.4r. Remote Closure Unit C2292

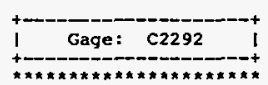

$\star * * \star *$ C2292 PI Comments $* * * * *$

09/02/93 TLC:GTB (RANK=101 THE DATA ARE OUTSTANDING. THIS HORIZONTAL CLOSURE AFTER MINING OF THE INTERMEDIATE SCALE BOREHOLE. [COMPRESSION 18.61:1] (DEM)

\#*** C2292 Location *****

Princlpal station
Station

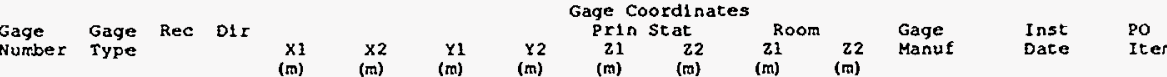

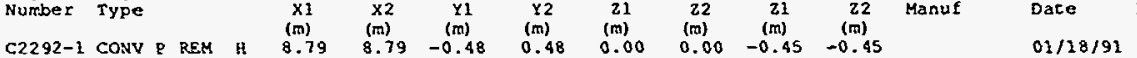

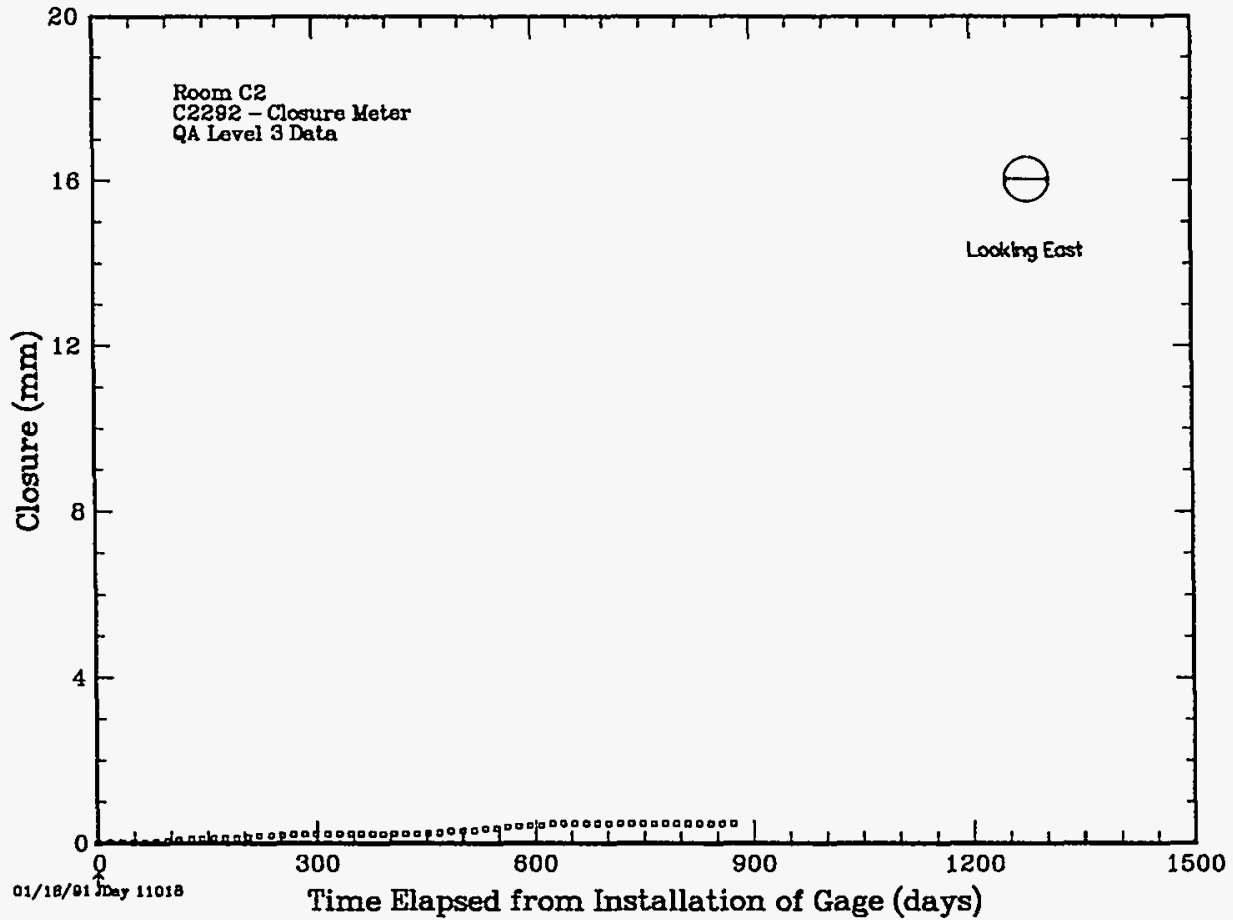

Figure 5.1.2r. Remote Closure Unit C2292 
5.1.3 Extensometer Measurements; A guide to the location of all extensometer units is given in Table 5.1.5. This table illustrates schematically the relative gage positions at the principal stations. All extensometers were installed into the pillar from the N1420 entry drift. The installations were at three principal stations, $-6,-3$, and $0 \mathrm{~m}(-20$, -10 , and $0 \mathrm{ft}$ ). At each principal station, four horizontal extensometer units are located at $2,1,0.3$, and $0 \mathrm{~m}(6,3,1$, and $0 \mathrm{ft})$ above the centerline of the borehole. The gages at the $0.3 \mathrm{~m}$ elevation were not initially planned; however, an error in surveying was corrected by the additional gages. Each unit is composed of five extensometer anchors, each located at different $\mathrm{Y}$-coordinate depths. These coordinates are, nominally, at $2,1,0,-1$, and $2 \mathrm{~m}(6,3,0,-3$, and $-6 \mathrm{ft})$. This positioning essentially spreads the anchor locations at right angles to the intermediate scale borehole axis and through the volume of salt above the borehole, in a three-dimensional array.

Descriptions and locations of each extensometer and the PI comments are given in Tables 5.1.6a-1. Plots of reduced data for the individual units are given in Figures 5.1.3a-1. The following paragraphs summarize the data and provide some preliminary interpretations and relevant observations.

Extensometers measure the relative displacements between the collar of the emplacement hole and the multiple anchors placed at several depths in the hole over the range of deformation allowed by the instrument. The data obtained have a wealth of information that is not straightforward to interpret. Under normal conditions, extensometer measurements are delayed after excavation because of the time required for drilling emplacement holes and installing the extensometers. While this is certainly true of 
Table 5.1.5. Extensometer Units (Gages) Location Guide

pillar interior

Relative Location

STA -6

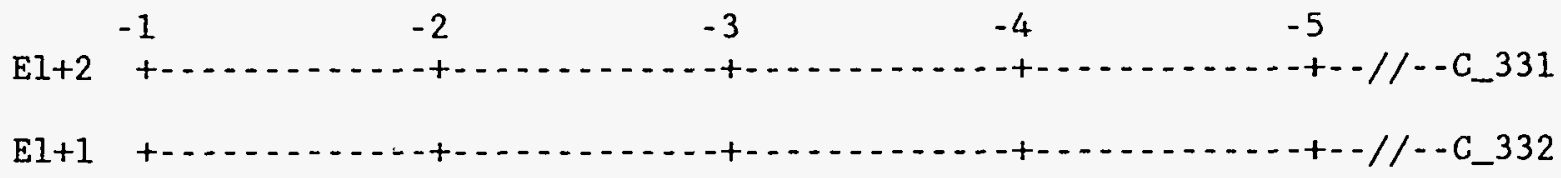

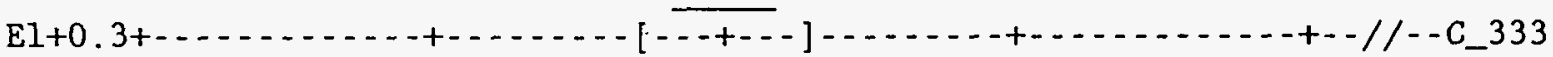

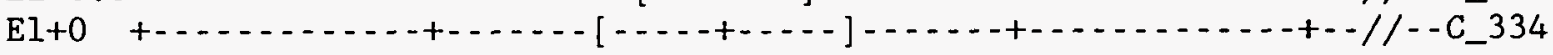

STA -3

\begin{tabular}{|c|c|c|c|}
\hline-1 & -2 & -3 & -4 \\
\hline
\end{tabular}

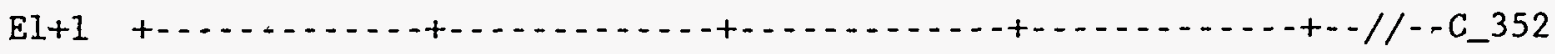

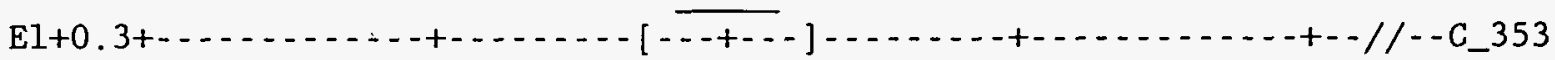

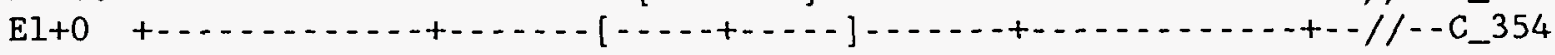

STA 0

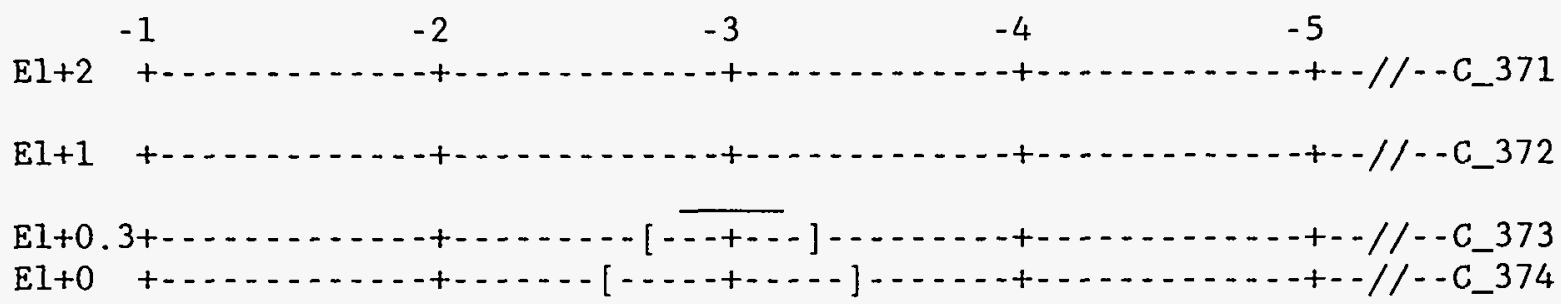

these gages with respect to the displacements in the pillar as a result of the excavation of the Rooms $C$. As noted in the beginning of section 5.1 , this time delay causes significant early time displacements of the pillar to be excluded from the data. However, this is not the case with respect to the intermediate scale borehole. In fact, all of the extensometers were installed and recording displacements prior to excavation (drilling) of the intermediate scale borehole. For displacement histories to be complete representations of the creep behavior, the displacement histories 
must be reconstructed to include these unmeasured pillar displacements. Because of the more than 6 years delay in extensometer installation for this test, any meaningful reconstruction of the lost pillar deformation data is probably not possible. However, this has little real consequence because our remarks and interpretation are based entirely on the changes induced in the displacements by the drilling of the borehole and the details of the specific units.

After very careful examination of the data, including reconfirming the installation procedure, it is evident that the extensometers were still in a state of transition from the initial installation, which was further aggravated by maintenance crew activity during reinstallation of some mined out anchors. Normally, the wire extensometers exhibit "hysteresis" caused by the elastic stretching of the wire. The hysteresis is apparent from a slow initial increase in measured closure displacement to a higher closure rate actually typical of creep closure, this rate then diminishes with time as expected. Usually, the more rapid closure rates of a newly mined room cause the initial hysteresis to be overcome rapidly and to represent little problem in the interpretation of the actual closure rate from the data. However, because these extensometers were installed in an old, slowly deforming pillar, there is apparently insufficient deformation to eliminate the hysteresis effect. This state was further exacerbated by the relatively short, two month, time between installation and drilling of the intermediate scale borehole. As planned, the extensometers were to be installed for a year prior to the drilling of the hole. The unavoidable installation delays significantly diminished the time available for the establishment of a baseline response as planned.

If the extensometer data prior to the drilling of the hole are 
examined, no regularity in the deformation rates as a function of anchor location is apparent. What is apparent is that the shallow anchors seem to be eliminating the hysteresis effect somewhat quicker than the deep anchors, probably because the longer wire lengths have to take up more deformation to eliminate the elastic strain of the hysteresis. It is doubtful that any analysis of these early time displacements would be meaningful.

Interestingly, there is little apparent affect of the drilling on the slope of the displacement curves, as is evident from the data of those gages not mined out by the drilling operation, C_331, C_332, C_351, C_352, C_371, and C_372. For all those gages that were mined out, C_333, C_334, C_353, C_354, C_373, and C_374, and subsequently reinstalled at about 100 days, the hysteresis was so pronounced that little useful information was produced. In fact, only two of these units have been able to reestablish themselves to give what might be considered a reasonable response.

At the precise day of the maintenance operation, at about 100 days, all of the gages were again apparently perturbed in such a way as to introduce another period of hysteresis. In all of the gages that can be evaluated, this perturbation produced the same effect as the initial installation, with the longer gage wires requiring a longer recovery time.

Only at very long times can we postulate that the extensometer gages are responding to the actual pillar deformations. Here, even though the curves are displaced in time according to various amounts of hysteresis, the slopes all appear to be taking up very similar rates. This indicates that the pillar response is relatively uniform, as one would expect.

[text continues on page 107] 
Table 5.1.6a. Extensometer Unit C_331

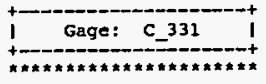

\#*** C_331 PI Comentent *****

$09 / 02 / 93$ TLC: GTB [RANK $=10(1), 10(2), 10$ (3),10(1), 10(5)] THE DATA FROM THIS UNIT ARE OUISTANDING. THIS EXTENSOMER CAUSPD BY MAINTENAHCE ACTIVITIES ON OTHER GAGES, AND WAS NOT CORRECTED. VERY LITTLE REDUCTION WAS REQUIRED EXCEPT FOR MINOR DELETION OF SCATTER AND A SHIF OF THE DATA DOWMWARD AT DAY 102. THE SHIFT WAS NECESSARY BECAUSE THE UNIT WAS DISTURBED DURING THE REINSTALLATION OF C_333 AND C_334. [COMPRESSION 17.52:1] (DEH)

***** C_331 Location *****

Principal station

Gage Gage Rec D1r

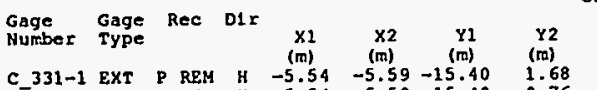

C.331-2 EXF P REM H

C-331-3 EXT P REM H

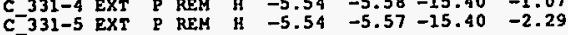

Gage Coordinates ${ }_{\mathrm{z} 1 \mathrm{n}}$ Stat 21
(m)
1.66 $\begin{array}{ll}1.66 & 2.12 \\ 1.66 & 2.10\end{array}$

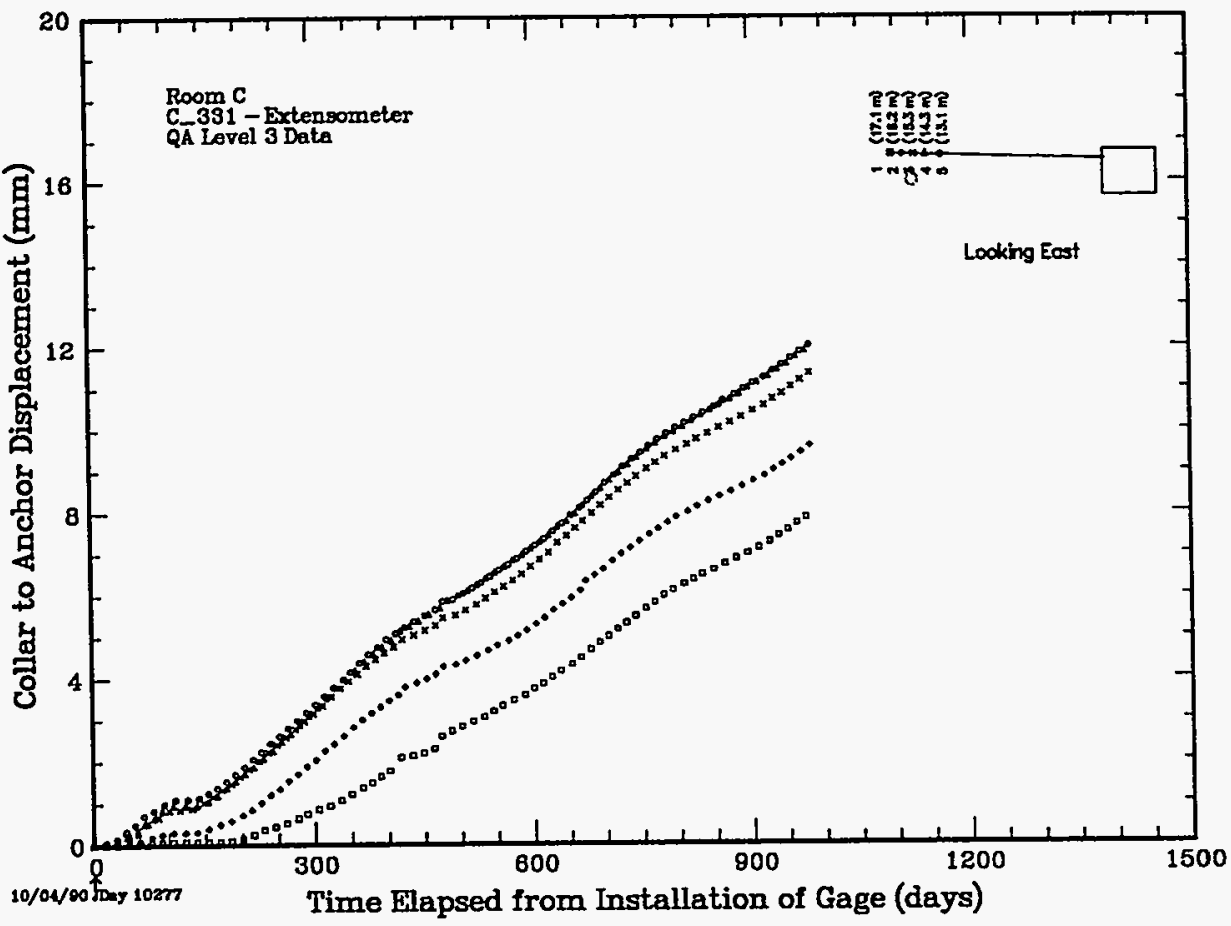

Figure 5.1.3a. Extensometer Unit C_331 
Table 5.1.6b. Extensometer Unit C_332

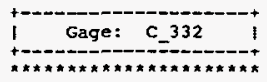

*****C 332 PI Comments *****

09/03/93 TLC: GTB [RANK $=10(1), 10(2), 10(3), 10(4), 10(5)$ ] DATA EROM THIS UNIT ARE OUTSTANDING. THIS EXTENSOMETER UNIT WAS INSTALLED 59 DAYS BEFORE MINING OF THE INTERMEDIATE SCALE BOREFOLE. VERY LITTLE REDUCTION WAS REQUTRED EXCEPT FOR MTNOR OELET

DS TUR INIE DURING REPLACEMLNT A

CORRECTIVE ACTIONS KERE TAKEN IN THESE CASES [COMPRESSION $18.17: 1$ ] (DFM)

$\cdots \times \times$ C_ 332 Location $* a * * *$

Principal station

Station

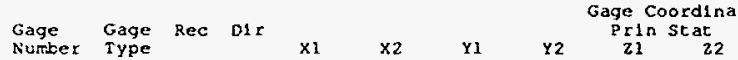

$\begin{array}{cccccccc}\text { C } 332-1 & \text { EXT } & \text { P REM } & \text { H } & -5.54 & (m) & (m) & (m) \\ -5.54 & -15.38 & (m .69\end{array}$

$\begin{array}{llllll}\text { C-332-2 EXT P REM H } & -5.54 & -5.54 & -15.38 & 0.77\end{array}$

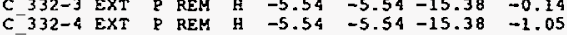

C $332-5$ EXT $\mathrm{REH}$ H $-5.54-5.54-15.38$

2122 Room 22 Gage

$\begin{array}{ll}\text { Inst } & \text { Po } \\ \text { Date } & \text { Item }\end{array}$

Comments

$09 / 04 / 90$

$09 / 04 / 90$

$09 / 04 / 90$

$09 / 04 / 90$

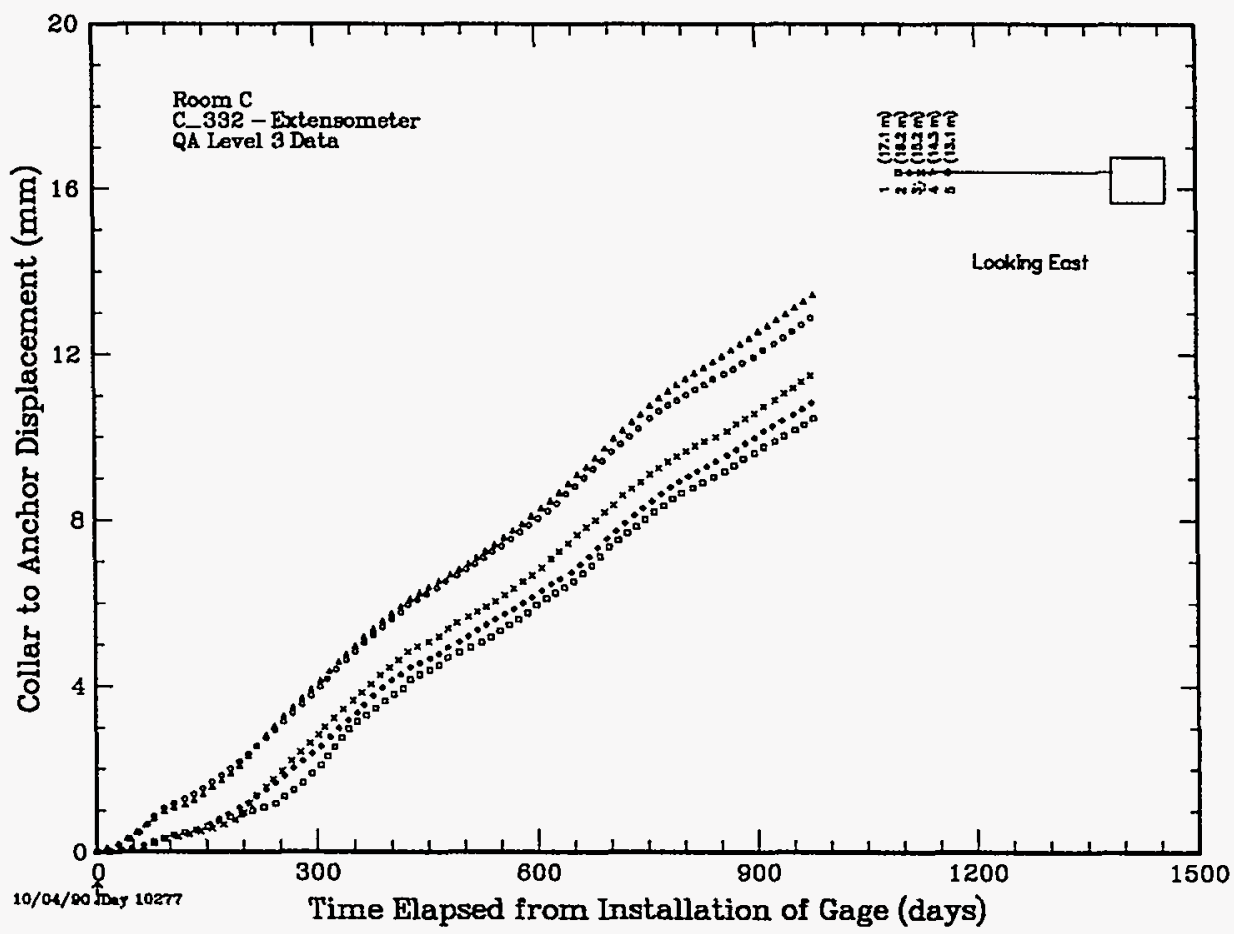

Figure 5.1.3b. Extensometer Unit C_332 
Table 5.1.6c. Extensometer Unit C_333

$$
\text { tore: }
$$

...... c_333 pi comments.... .

09/03/93 TLC:CTB:DEM [RANK $=2(1), 20(2), 10(3), 10(4), 10(5))$ THIS EXTENSOMETER TLHEDIATE SCALE BOREHOLE. GACES -1, -2 AND -3 WERE CUT BY THE DRTLL CORE BIT CN DAY T1 (JULIAN DATE 10350 AND REINSTALLED BY WAY 100 TJULIAN DHTE

REDT TO ZERO ON DAY IOO. AFE THE UAGE REINSTALCATION AND PRODUCED EXTPEMELY SCATTERED DATA. THE GAGE -1 DATA WERE DELETED PROM DAY 543 TO 857. A FURTHER REINSTALATION OCCURRED ON DAY 904. [COMPRESSION 3.93:1] (DEM)

...... c_333 Location $\ldots . .$. .

$$
\text { Principal station }
$$

Gage Gage Res Dir

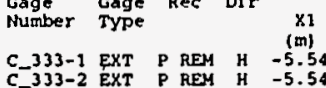

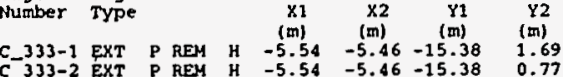

\begin{tabular}{llllll}
$C-333-3$ & EXT P REM H & -5.54 & -5.46 & -15.38 & 0.77 \\
\hline
\end{tabular}

C-333-4 EXT P REA H

Gage Coordinates

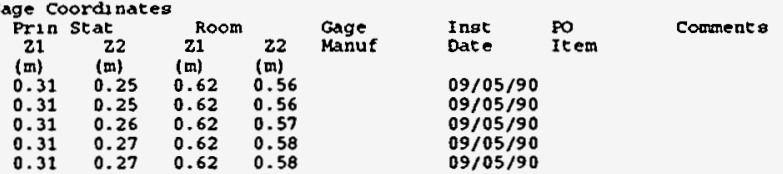

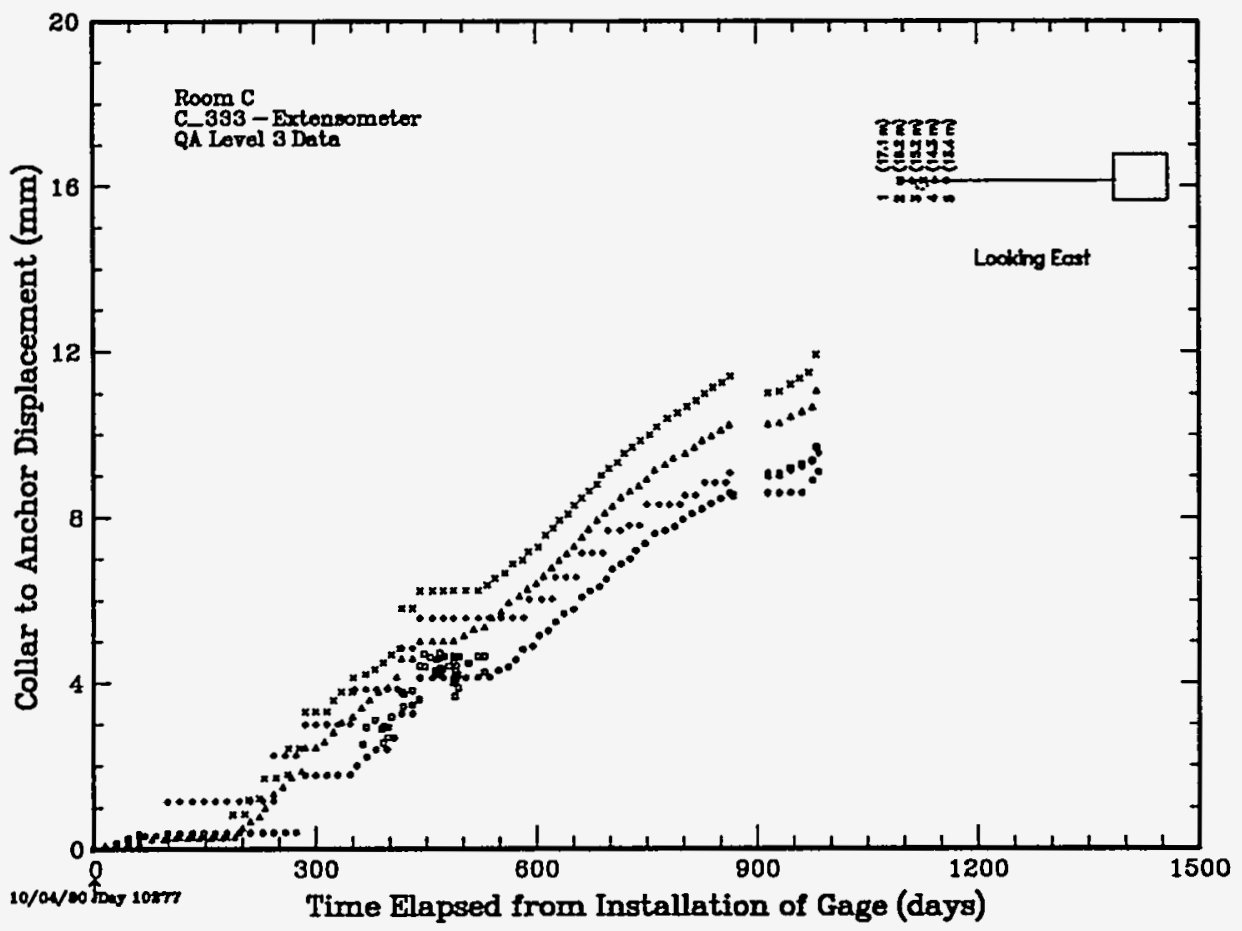

Figure 5.1.3c. Extensometer Unit C_333 
Table 5.1.6d. Extensometer Unit C_334

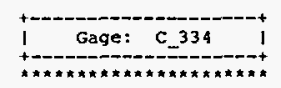

***** C_334 PI Corments $* * a * *$

09/03/93 TLC:GTB [RANK $=10(1), 10(2), 10(3), 10(4), 10(5)$ ] THIS EXTENSOMETER UNIT WAS INSTALIED 49 DAYS BEFORE MINING OF THE INTERMEDIATE SCALE BOREHOLE. GAGES $-1,-2$ AND -3 WERE CUT ON THE FIRST DAY OF MINING AND REINSTALLED BY DAY 90.

GAGE -3 NEVER RESPONDED AND WAS DEACTIVATED. GAGES -4 AND -5 WERE RESET TO
ZERO UPON REINSTALLATION OE THE OTHER GAGES. THE EXTENSIVE HYSTERESIS EEFECTS

THAT $\propto$ CUR AFTER IHE REINSTALLATION WERE NOT CORRECTEO, HOKEVER, THIS CAUSES

THE VERTICAL SHIFT IN THE DATA. DURING THE HYSTERESIS, THE DISPLACEMENT THAT

THE VERTICAL SHIFT IN THE DATA. DURING THE HYSTERESTS, THE DIS,
SHOULD HAVE BEEN MEASURED IS LOST. [COMPRESSION $16.29: 1$ (DEM)

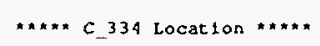

Principal station

Station

Gage Gage Rec olr Gage coordinates

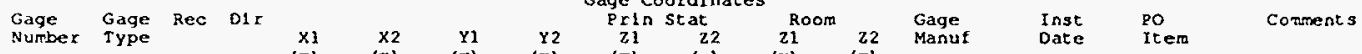

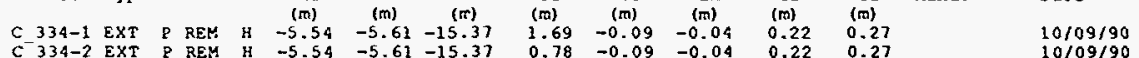

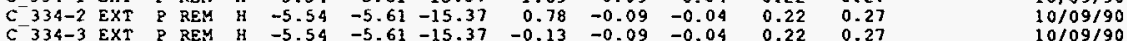

$\begin{array}{llllllllll}C-334-3 & \text { EXT P REM } & -5.54 & -5.61 & -15.37 & -0.13 & -0.09 & -0.04 & 0.22 & 0.27 \\ c^{-3} 34-4 & \text { EXT } & 0.27 & 0.22 & 0.27\end{array}$

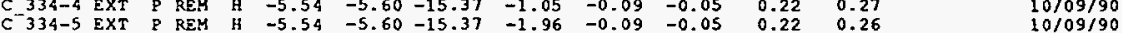

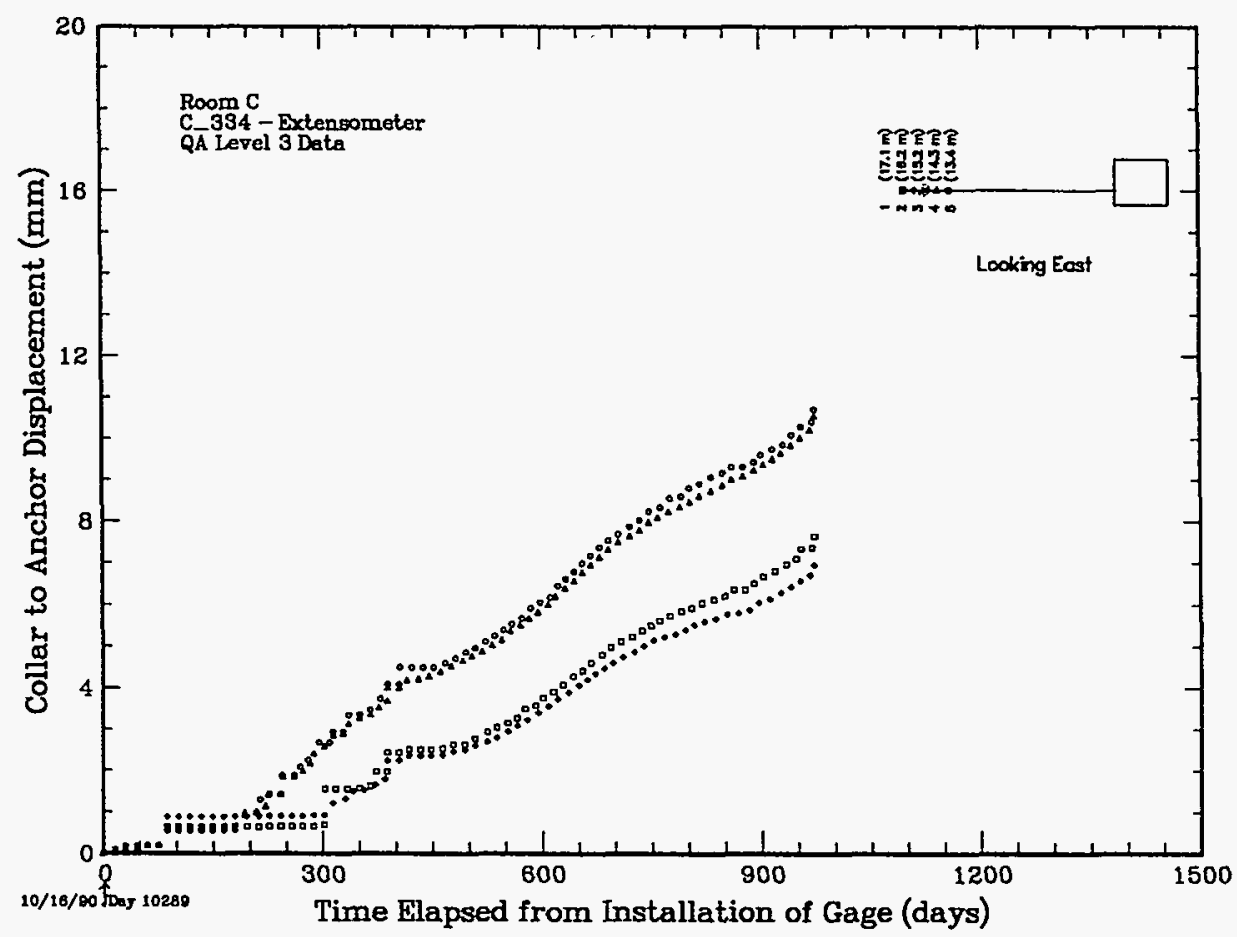

Figure 5.1.3d. Extensometer Unit C_334 
Table 5.1.6e. Extensometer Unit C_351

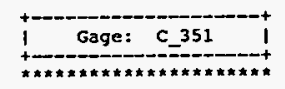

***** C_351 PI Comments *****

09/03/93 TLC: GTB [RANK $=10(1), 10(2), 10(3), 10(4), 10(5)$ ] THIS EXTENSOMETER UNI] WAS INSTALLD 59 DAYS BEFORE MINING OF THE INTERMEDIATE SCALE BCREHOLE. TWO SHIFTS IN THE DATA $\propto$ CCURRED, ONE ON DAY 31 AND THE OTHER ON DAY 102, PROBABLY AS THE RESULT OF MAINTENANCE, RATHER THAN THE DRILEING OF THE BOREHOLE. THE

RESULTING HYSTERESIS EVENTUALLY RECOVERED AS IS EVIDENT,
ATTEMPT TO CORRECT THE DATA. [COMPRESSION 17.95:1] (DEM).

***** C_351 Location *\#***

Princlpal station Station

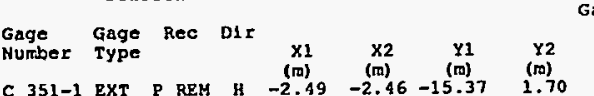

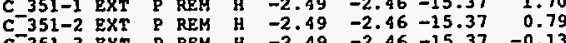

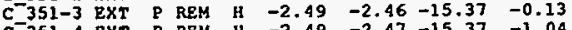

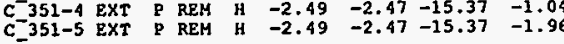

\begin{tabular}{lcccc}
\multicolumn{2}{c}{ ge Coordinates } & & & \\
Pr1n & Stat & Room & & Gage \\
21 & 22 & Z1 & Z2 & Manuf \\
(m) & (m) & (m) & (m) & \\
1.71 & 1.99 & 1.88 & 2.16 & \\
1.71 & 1.98 & 1.88 & 2.15 & \\
1.71 & 1.96 & 1.88 & 2.13 & \\
1.71 & 1.94 & 1.88 & 2.12 & \\
1.71 & 1.93 & 1.88 & 2.10 &
\end{tabular}

Inst po

Coments

$08 / 30 / 90$ $08 / 30 / 90$

$08 / 30 / 90$ $08 / 30 / 90$ $08 / 30 / 90$

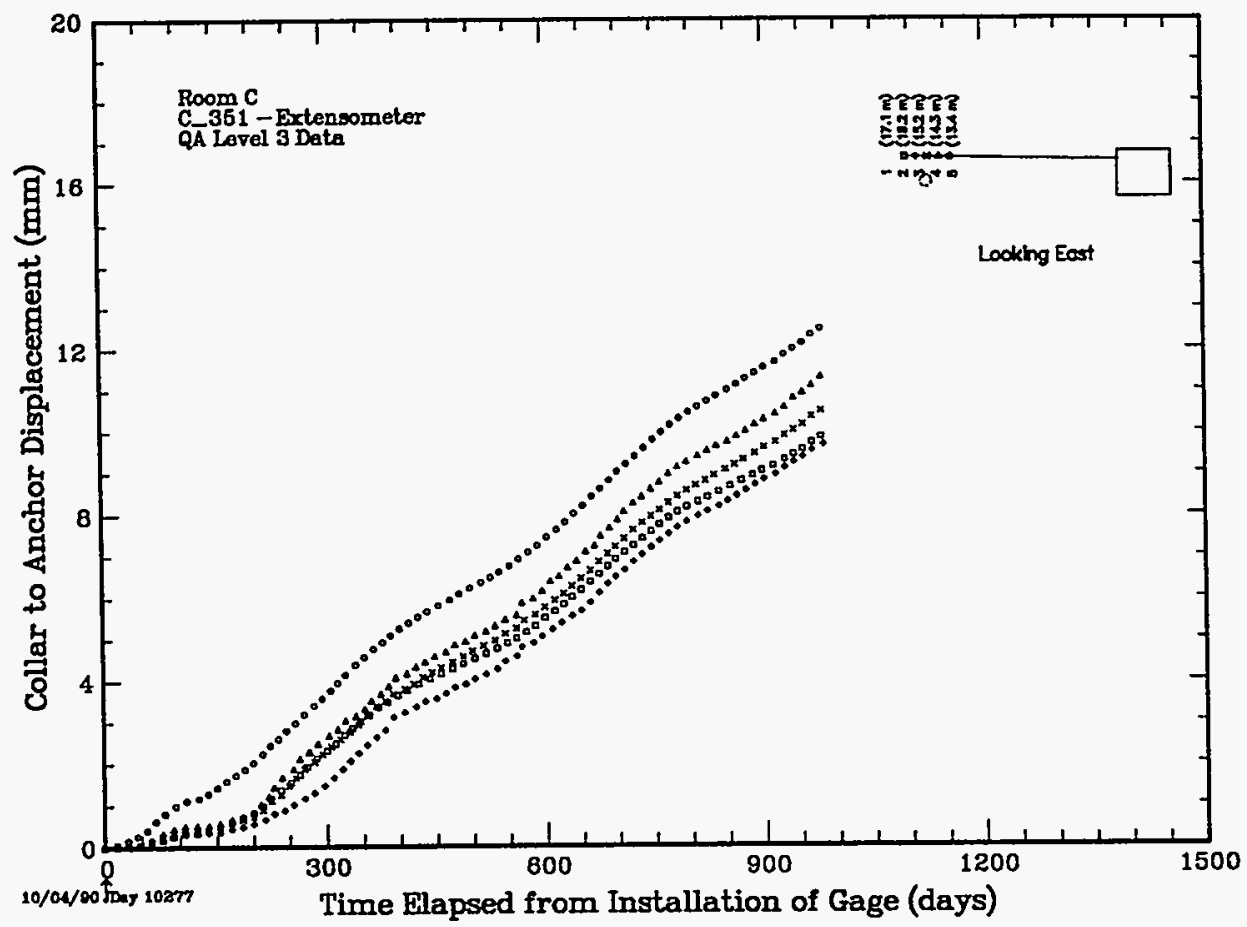

Figure 5.1.3e. Extensometer Unit C_351 
Table 5.1.6f. Extensometer Unit C_352

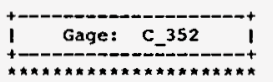
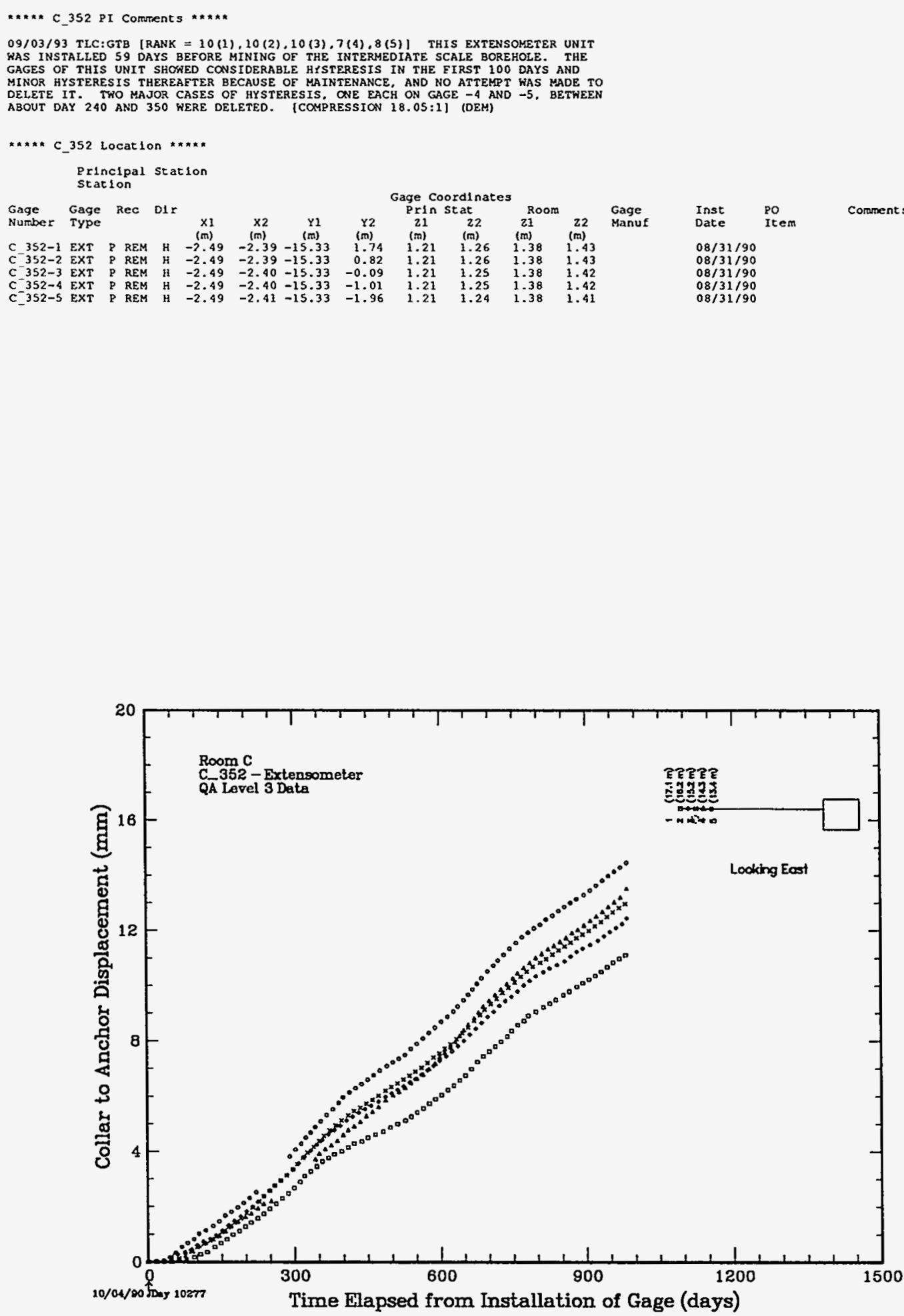

Figure 5.1.3f. Extensometer Unit C_352 
Table 5.1.6g. Extensometer Unit C_353

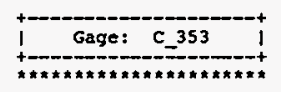

A**** C_353 PI Comments ******

09/03/93 TLC:GTB (RANK $=10(1), 10(2), 8(3), 10(4), 10(5)$ ] THIS EXTENSOMETER UNIT WAS INSTALLED 59 DAYS BEFORE MINING OE THE INTERMEDIATE SCALE BOREHOLE. THE BOREHOLE. THE UNIT WAS REINSTALLED. THERE WAS EXTENSIVE HYSTERESIS SHOWN BY THE GAGES OF THE UNIT BOTH AT THE TIME OE REINSTALLATION AND LATER, VERY LTTTLE

OF WHICH IT WAS POSSIBLE TO DELETE. THE HYSTERESIS AT ABOUT DAY 103 AND AT

ABOUT DAY 400 WERE YHE RESULF OF MATNTENANCE ACTIVITIES. THERE WERE ALSO
NUMEROUS SHIFTS OF THE DATA FOR UNKNOFN REASONS. [COMPRESSION 17.21:1] (DEM)

**A** C_353 Location **n**

Principal station

station

Gage Coordl nates

Gage Gage tee 01

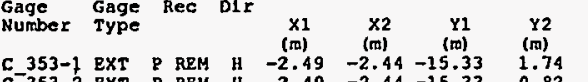

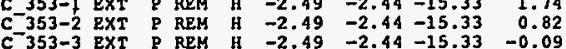

C.353-4 $\times 1$ P

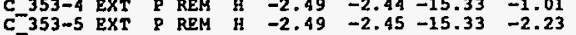

$\begin{array}{llll}\text { Prin Stat } & \text { Room } & \text { Gage } \\ 21 & 22 & \text { Manuf }\end{array}$

$\begin{array}{llll}(m) & (m) & (m) & (m) \\ 0.29 & 0.14 & 0.46 & 0.31\end{array}$

$\begin{array}{llll}0.29 & 0.14 & 0.46 & 0.31 \\ 0.29 & 0.15 & 0.46 & 0.32\end{array}$

$\begin{array}{lllll}0.29 & 0.16 & 0.46 & 0.33 \\ 0.29 & 0.16 & 0.46 & 0.34\end{array}$

$\begin{array}{llll}0.29 & 0.16 & 0.46 & 0.34 \\ 0.29 & 0.18 & 0.46 & 0.35\end{array}$

$\begin{array}{ll}\text { Inst } & \text { Po } \\ \text { Date } & \text { Ite } \\ 09 / 05 / 90 \\ 09 / 05 / 90 \\ 09 / 05 / 90 \\ 09 / 05 / 900 \\ 09 / 95 \\ 09 / 05 / 90\end{array}$

Comronts

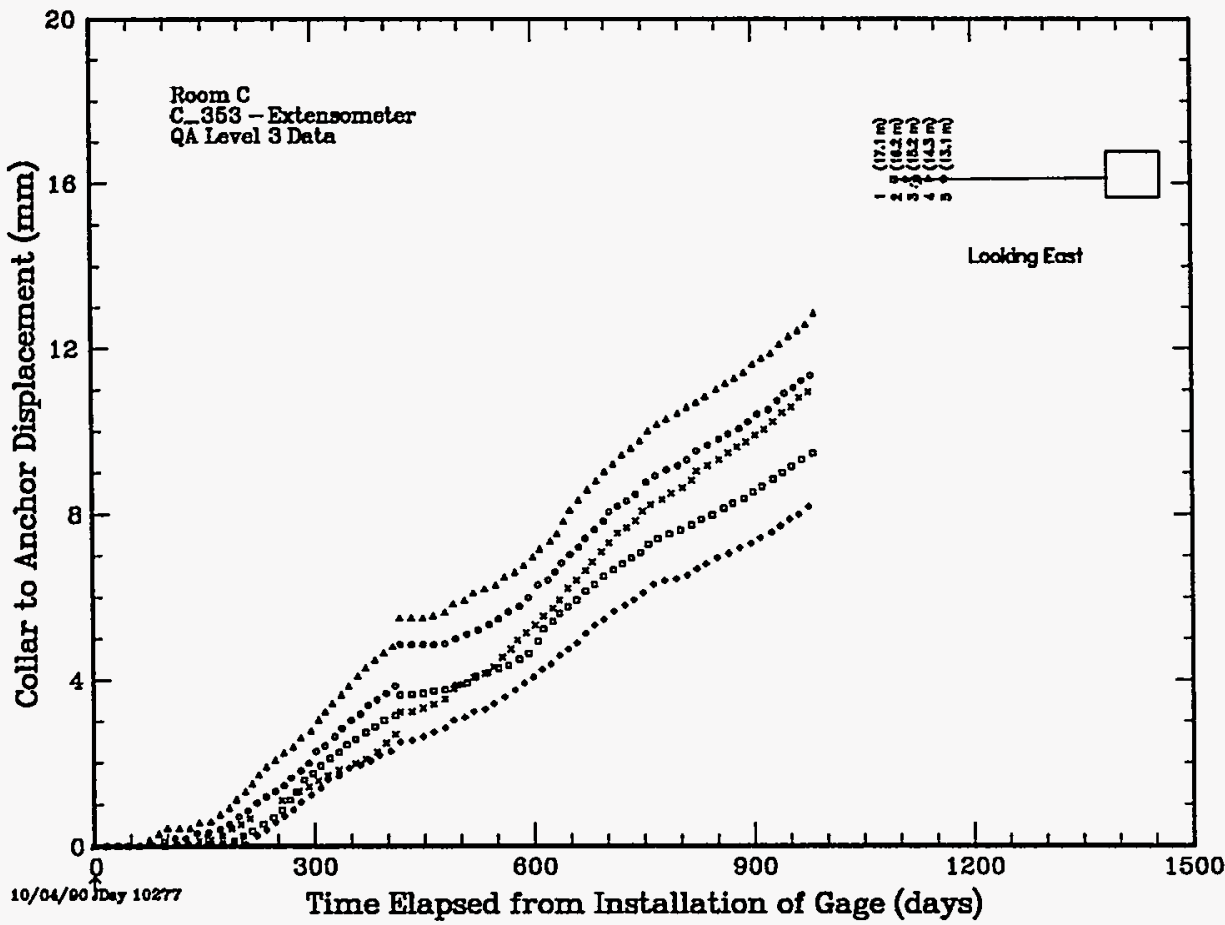

Figure 5.1.3g. Extensometer Unit C_353 
Table 5.1.6i. Extensometer Unit C_371

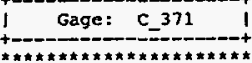

*\#*** C_371 PI Comments $\star \star \star \star * *$

09/02/93 TLC: GTB IRANK $=10(1), 10(2), 10(3), 10(4), 10(5)$ I THIS EXTENSOMETER UNIT WAS INSTALLED 59 DAYS BEFORE MINING OF THE INTERMEDIATE SCALE BOREHOLE. LITTLE WAS NECESSARY EXCEPT FOR MINOR DELETYON OF SCATTER AND MYSTERESIS, AND A SHIET OF THE DATA DOWNARD PROBABLY DUE TO THE REINSTALLATION OF UNITS C 333 AND C 334 AT DAY 103 (JULIAN DATE 11015). BECAUSE THE DRILLING OF THE BORERTLL JUL

ACBPNTIALIY HYSTERESIS WHICH EVENT

***** C_371 Location **k**

Principal station Station

Gage Gage Rec D1r

C $371-1$ EXT P REM H $\quad \stackrel{(m)}{0.56}$

$\mathrm{C}^{-} 371-2$ EXT P REM $\mathrm{H} \quad 0.56$

C-371-3 EXT P REM

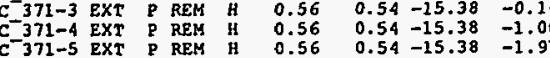

$\begin{array}{lll}0.54 & -15.38 & -1.06 \\ 0.54 & -15.38 & -1 .\end{array}$
Gage

Manuf

98

.97

1.96

1.94
1.93
Inst
Date

$08 / 24 / 90$

$08 / 24 / 90$

$08 / 24 / 90$

$08 / 24 / 90$

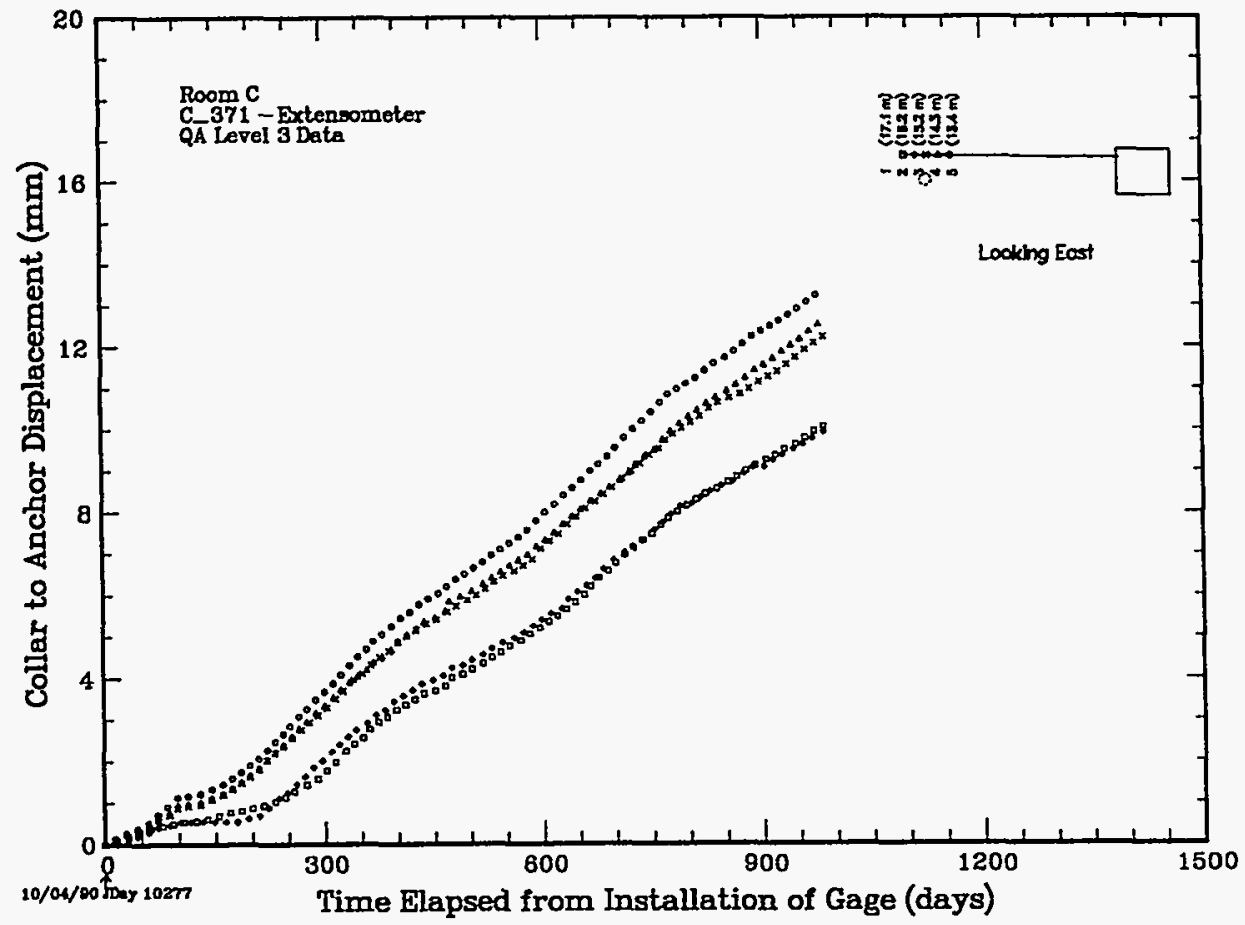

Figure 5.1.3i. Extensometer Unit C_371 
Table 5.1.6j. Extensometer Unit C_372

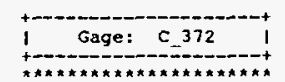

axa* C 372 P1 Comments $a$ ana*

$09 / 02 / 93$ TLC: GTB [RANK $=10(1), 10(2), 10(3), 10(4), 10(5)$ ] THIS EXTENSOMETER UNIT WAS INSTALLED 59 DAYS BEFORE MINING OF THE INTERMEDIATE SCALE BOREHOLE. LITTLE REDUCTICN HAS NECESSARY EXCEPT FOR MINOR DELETION OE SCATTER AND SHIFTS OE THE DATA DUE TO MAINTENANCE OR REINSTALLATION OF THE GAGES OF THE UNIT AND SOME MAINTENANCE AND EVENTUALLY RECOVERS. [COMPRESSION 18.05:1] (DEM)

**** C 372 Location *****

Princlpal station

$$
\begin{aligned}
& \text { Princlpal } \\
& \text { Station }
\end{aligned}
$$

Gage Gage Rec DIX

$$
\text { Gage coordinates }
$$

$\begin{array}{llll}X I \\ C-372-1 \text { EXT \& REM H } & 0.56\end{array}$

C- $372-2$ EXT Q REM

$\begin{array}{lllll}c & 0.56 & 0.48 & -15.33 & 0.82\end{array}$

$\begin{array}{llllll} & \end{array}$

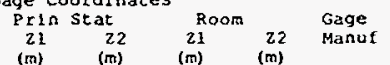

$\begin{array}{ll}\text { Inst } & \text { Po } \\ \text { Date } & \text { Item }\end{array}$

Compents

$08 / 28 / 90$

$08 / 28 / 90$

$08 / 28 / 90$

$08 / 28 / 90$

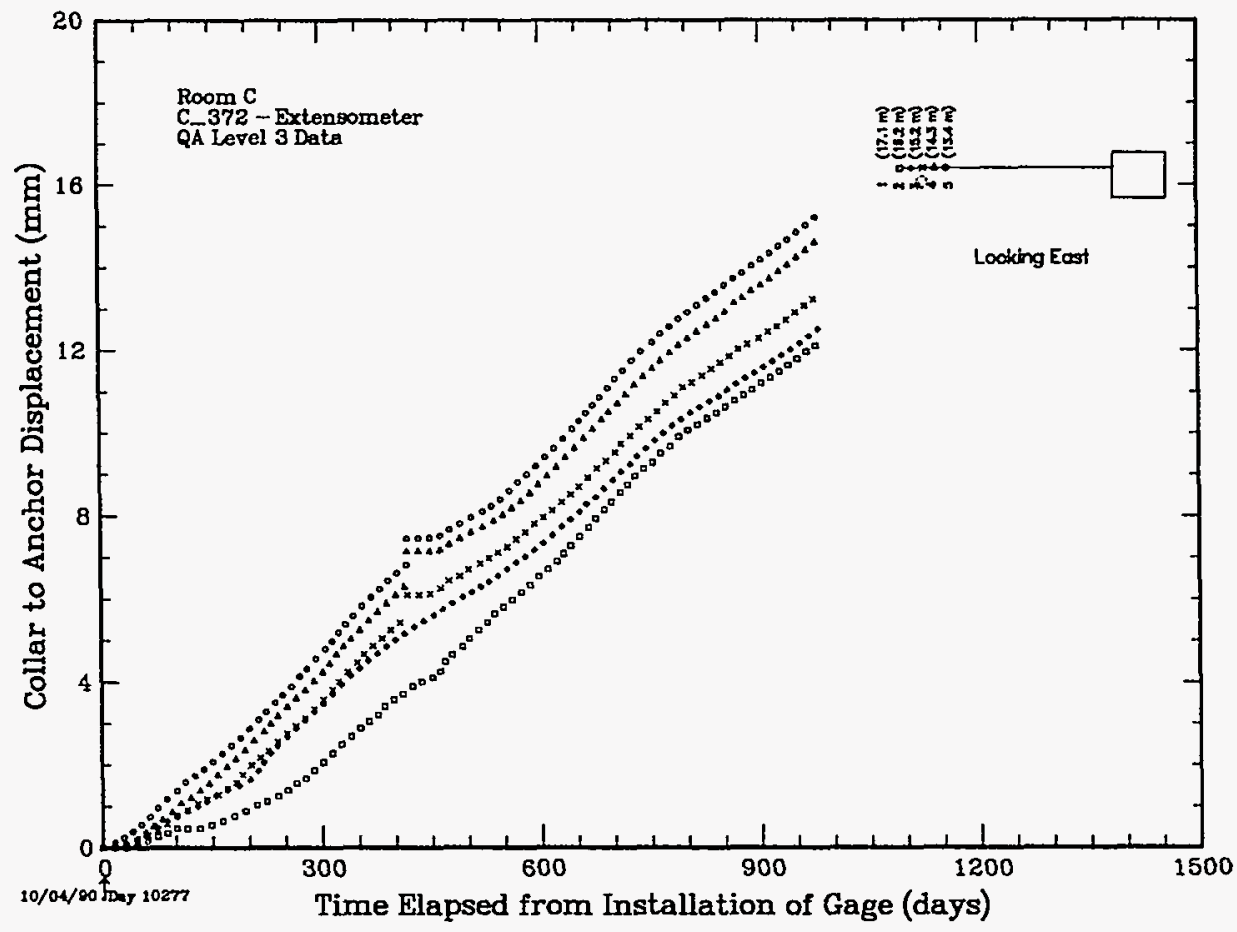

Figure 5.1.3j. Extensometer Unit C_372 
Table 5.1.6k. Extensometer Unit C_373

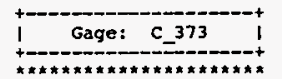

***** C_373 PI Comments $* * \hbar * *$

09/03/93 TLC: GTE (RANK E $6(1), 8(2), 8(3), 8(4), 8(5)$ T THIS EXTENSOMETER UNIT WAS FROM THIS UNIT APPEAR TO HAVE SEVERAL PROBLEMS. THE WIRES OF THE GAGE WERE CU WHEN THE BOREHOLE WAS DRILLED. ALTHOUGH THE GAGE WAS REINSTALLED, MAINTENANCE PROBLEMS AND MANY SUBSECUEN GAGE REINSTALLATIONS MAKE THE DATA VERY ROUGH. NUMEROUS DELETIONS AND SHIFTS OF DATA YERE REQUIRED. THE MAINTENANCE INDUCED
HYSTERESIS AT ABOUT 400 DAYS WhS LEET UNCORRECTED. [COMPRESSION $7.44: 1]$ (DEM)

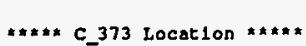
Principal station
Station

Gage Gage Rec D1r

C 373-1 EXT P REM H $\begin{gathered}X 1 \\ (\mathrm{~m}) \\ 0.56\end{gathered}$

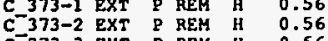

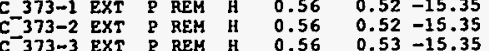

$0.53-15.35$

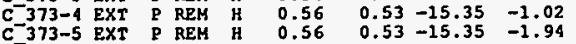

Gage
Manuf

Inst Po

Comsents

$08 / 28 / 90$

$08 / 28 / 90$

$08 / 28 / 90$

$08 / 28 / 90$
$08 / 28 / 90$

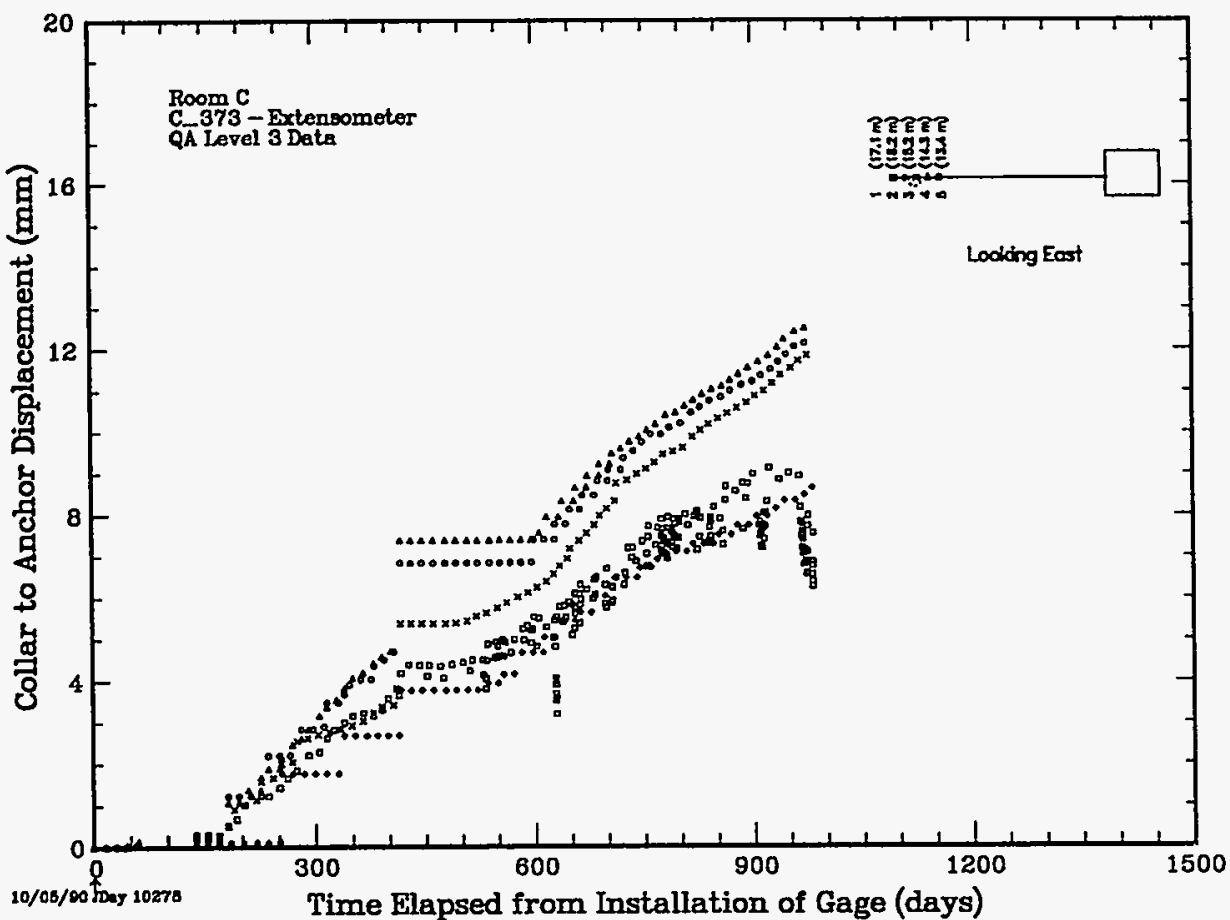

Figure 5.1.3k. Extensometer Unit C_373 
Table 5.1.61. Extensometer Unit C_374

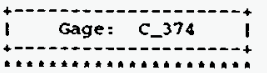

..... c-374 P1 Commentg $\ldots . .$.

09/03/93 TLC: GTB (RANK = $10(1), 10(2), 7(3), 8(4), 9(5)$ ) THIS EXTENSOMETER UNIT WAS INSTALLED 48 DAYS BEFORE MINING OF THE INTERMEDIATE SCALE BOREHOLE. THE WIRES OF THE UNIT WERE CUT DURING THE MINING PROCESS 55 DAYS (JULIAN DATE 10344) GAGE - 3 WHICH WAS DEACT IVATED MAJOR WYSTERESIS IN GAGES -4 AND -5 WAS DELETED FROM THE DATA. THE VERY LOW DISPLACEMENT RATES AFTER DAY 103 ARE THE RESULT OF MAINTENANCE ACTIVITIES AND NOT THE REINSTALLATION. A SIMILAR HYSTERESIS EFFECT TAKES PLACE AT ABOUT 400 DAYS. NEITHER OF THESE HYSTERESIS EFFECTS WERE CORRECTED DURING THE REDUCTION PROCESS. (COMPRESSION 17.94:1]
(DEM)

-.... c_374 Location.... . Principal Station

Guge Gage Rec Dir

$x_{1}$
(m)

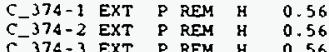

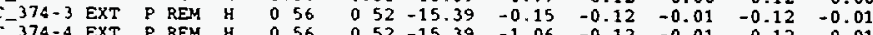

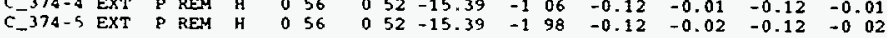

Gage Inst po coments

$10 / 11 / 90$

$10 / 11 / 90$

$10 / 11 / 90$

$10 / 11 / 90$

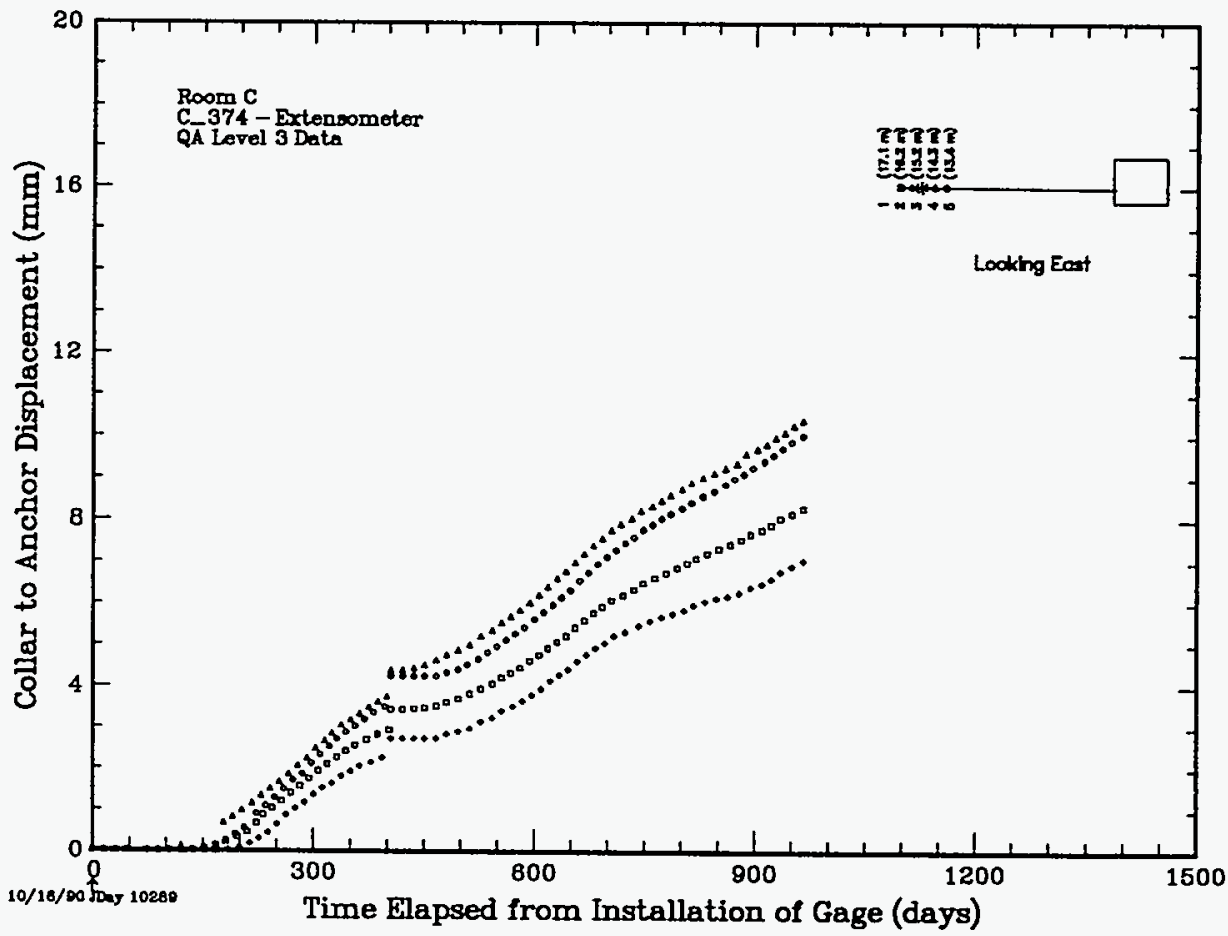

Figure 5.1.31. Extensometer Unit C_374 
5.2 Stress Measurements: The first type of stress meter installed in the Intermediate Scale Borehole Test was the strain-gaged stress meter (SGS). An SGS unit consists of two separate gages oriented at 0 and 90 degrees within the borehole (Figure 5.2.1). The SGS gages actually measure the strain in an elastic beam produced by the force on the gage platen. The applied force is converted to stress through a calibration. These gages all have numbers based on the format of $\mathrm{Cx} 5 \mathrm{xx}$.

The second stress meter type was a BuMines gage unit (Figure 5.2.1). This unit consists of an array of one cylindrical pressure cell (CPC) and two orthogonal borehole pressure cells (BPCs). The CPC senses the mean normal pressure (stress) in the plane normal to the cylindrical axis of the cell, whereas the BPCs are small flat jacks or pressure cells sensing the pressure (stress) normal to the flat face of the jack. BuMines "stress meters" actually measure cell pressure. These gages all have numbers based on the format of Cx6xx.

These two types of gages were used to assure that universal failure of one type would not result in total loss of data. In fact, the gages were grouped according to station, with the SGS gages forming the gage groups at either Principal Station -6 or 0 . The BuMines gages were all grouped at Principal station -3 .

Schematically, the relative locations of the units (gages) are shown in Table 5.2.1. However, because the emplacements involve two to three gages per unit, where each gage requires some considerable length of the drill hole, the actual axial extent of unit installation may be as much as $1.5 \mathrm{~m}(5 \mathrm{ft})$. In analysis of the results, this axial extent may be very critical within the stress field gradients and we recommend that the exact gage coordinates be used. 


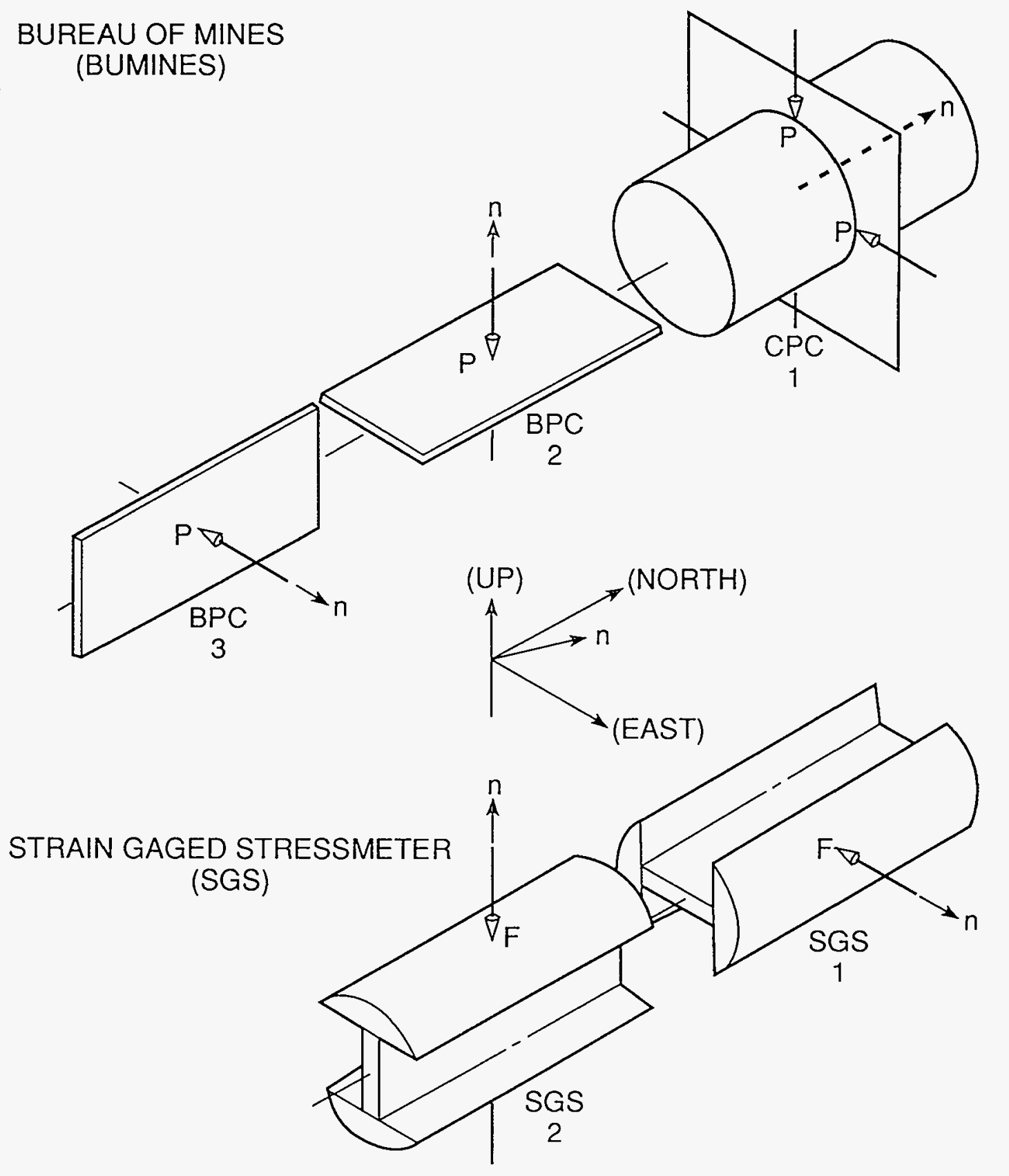

T/B-9251-33-13140

Figure 5.2.1. Schematics of SGS and BuMines Stress Meters 
Table 5.2.1. Stress Meter Units (Gages) Location Guide

Relative Location

pillar interior

N1420 entry rib

STA -6

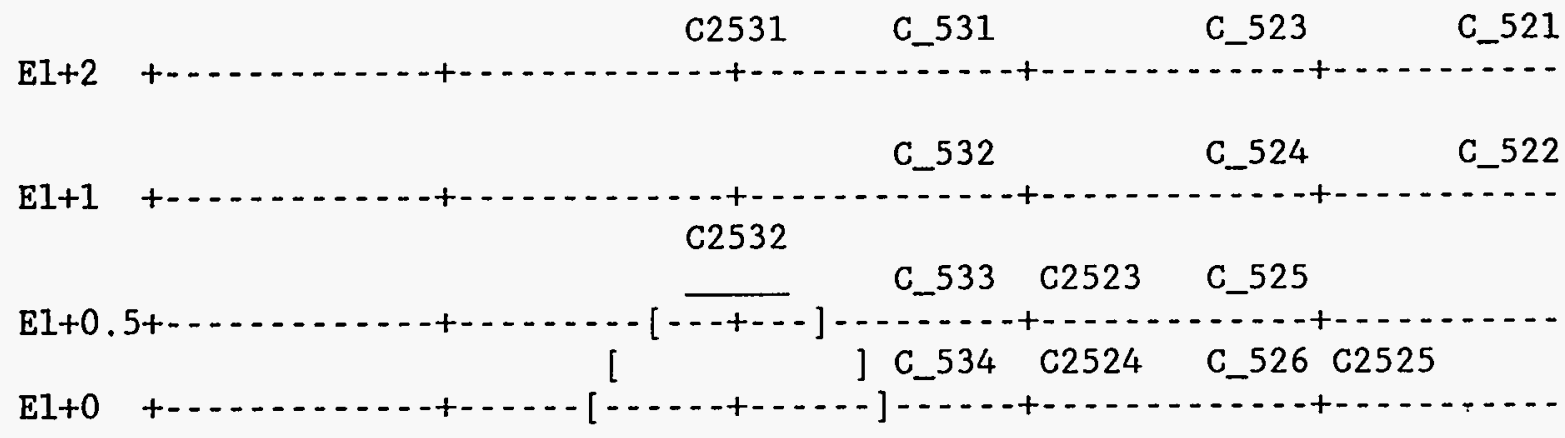

STA -3

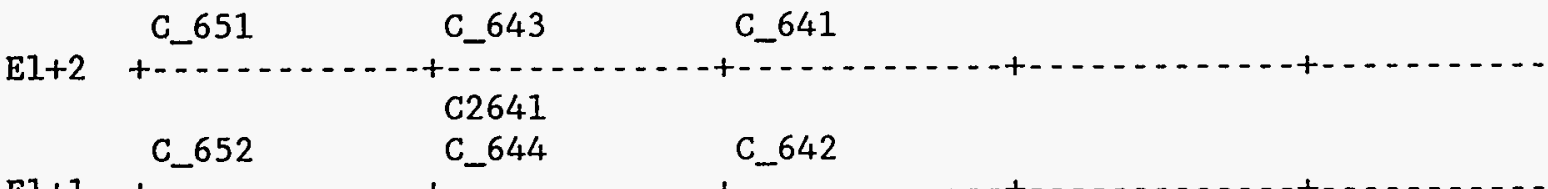

E1+1

C_653 C_645

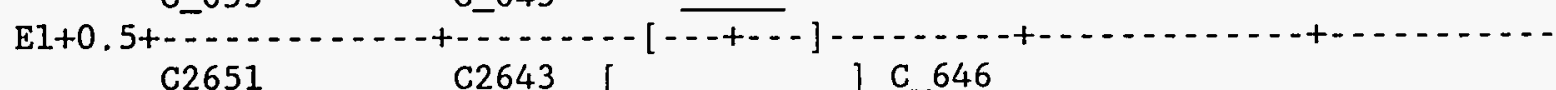

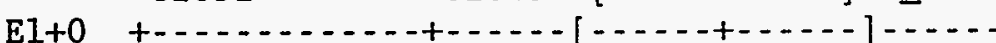

$$
\text { C_654 }
$$

STA 0

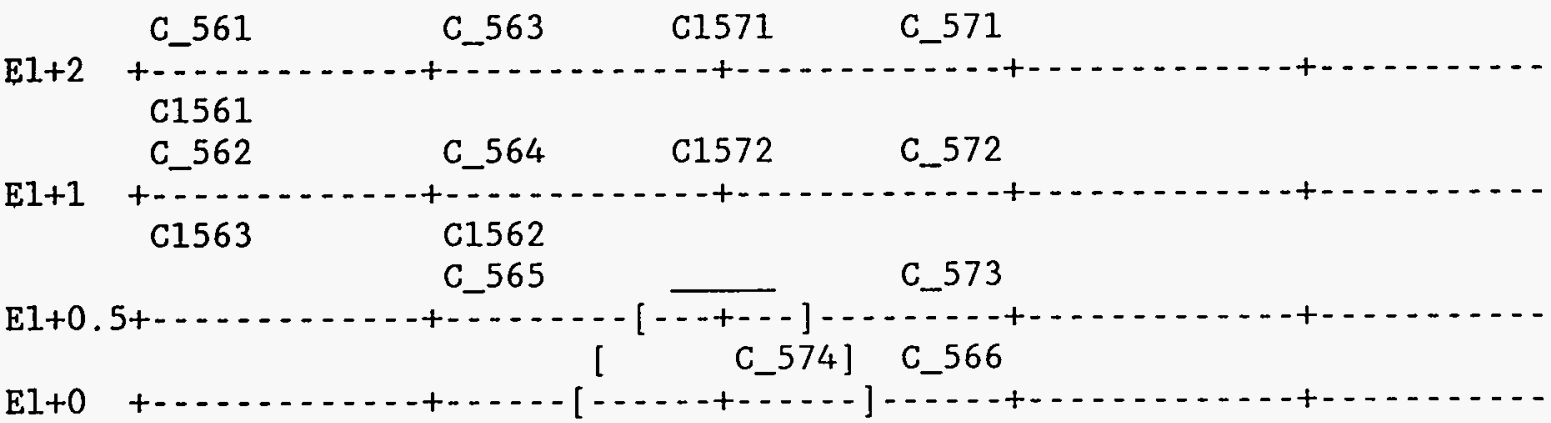


The SGS units were installed in instrument holes originating from the N1420 drift (gage designation C_5xx), from Room C1 (gage designation C15xx), and from Room C2 (gage designation C25xx). All of the SGS units were composed of two gages to measure the vertical and horizontal stress components. Although unit C_565 was installed, the installation hole went through the area to be drilled out by the intermediate scale borehole. Consequently, the transducer leads were cut at that time and could not be subsequently reestablished.

The BuMines gages were installed in instrument holes originating from the N1420 drift (with gage designations C_6xx) and from Room C2 (with gage designations $\mathrm{C} 26 \mathrm{xx}$ ). Two of the stress meter units (C_646 and C_654) did not include the cylindrical pressure (CPC) cell because the required location would cause interference with the intermediate borehole and would have been excavated during the drilling operation. For these two units, only vertical and horizontal BPC stress measurements were possible.

Each stress meter location and the PI Comments for the individual units are provided in Table 5.2.2a through 5.2.2ss. The corresponding reduced data plots are given in Figures 5.2.2a through 5.2.2ss.

The installation of gages from essentially two directions into the pillar mass resulted in the ability to measure the stresses in three dimensions. Thus, the units installed from the N1420 drift measure the horizontal stress in the $\mathrm{X}$-axis direction. The stress meters installed from Rooms $\mathrm{C} 1$ and $\mathrm{C} 2$ measure the horizontal stress in the Y-direction. All units measure the vertical stress in the $\mathrm{Z}$-direction.

As noted previously, the direction of the unit normal of the SGS gage is defined as being in the direction of the force on the elastic gage beam and. of the BuMines gage is defined as

[text continues on page 156] 
Table 2.2.2a. Stress Meter SGS Unit C_521

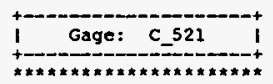

\#\#\#* C_521 PI Corswents *\#**

09/03/93 TLC:GTB (RANK $=10(1), 10(2)$ I THE DATA FROM THIS UNIT ARE OUTSTANDING. THIS SGS STRESS UNIT WAS INSTALLED 203 DAYS BEFORE MINING OF THE INTERMEDIATE OF SCARR . PHE RESULS OF THE MINING CAN THE VEAY SMALL PERTURBATION IN MEASURED STRESS AS SHOWN BY THE UNIT.

(COMPRESSION $2.71: 1$ ] (DEH)

***." C_521 Location *****

Principal station

Gage Gage Rec DIr

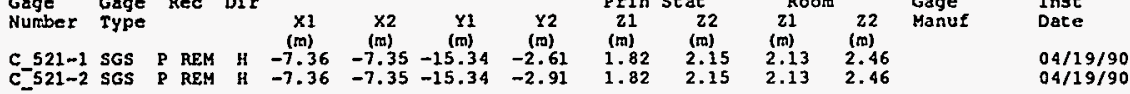

Gage Coordinates

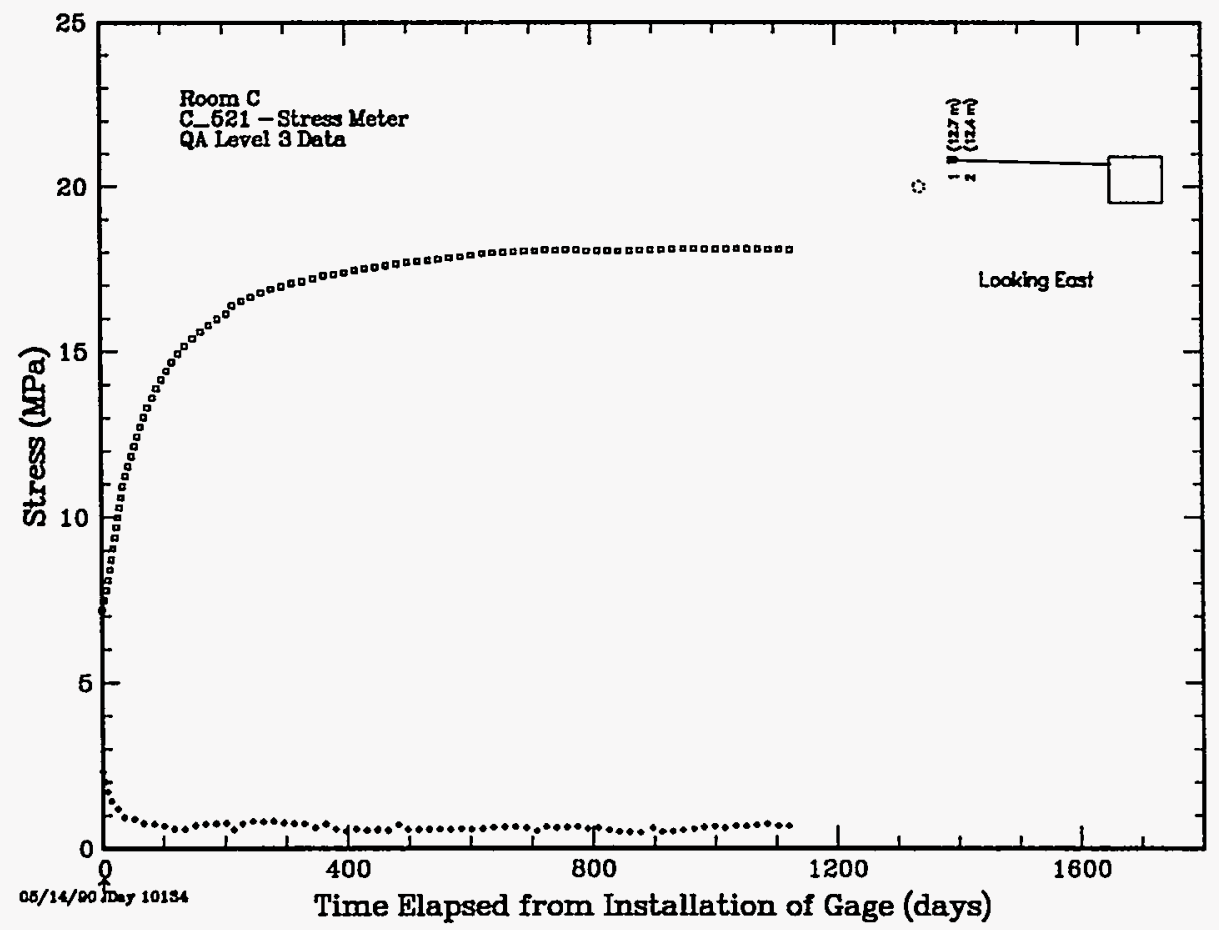

Figure 2.2.2a. Stress Meter SGS Unit C_521 
Table 2.2.2b. Stress Meter SGS Unit C_522

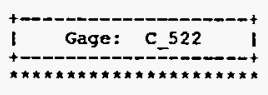

***** C_S22 PI Comments $* * * * *$

09/03/93 TEC: GTB [RANK = $10(1), 1$ (2) ] THIS SGS STRESS UNIT WAS INSTALLED 210

(JULIAN DATE 10152) AFTER INSTALLATION IN A SOMEWHAT UNUSUAL MANNER. ACTUALLY,

II APPEARS THE GAGE WAS SYMPLY UNLOADED. THE RESULTS OF THE MINING CAN BE SEEN STARTING AT DAY 210 AS THE PERTURBATION IN STRESS AS SHOWN BY THE UNIT.

\{COMPRESS ION $3.91: 1$ \} (DEM)

$\star * \star \star * C_{-} 522$ Location *****

Principal station Station

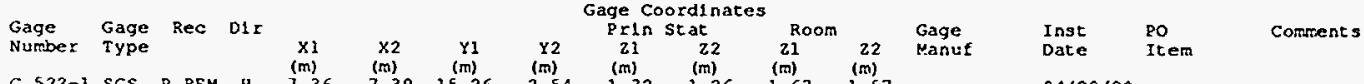

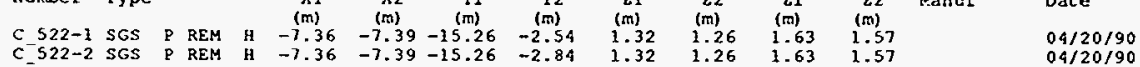

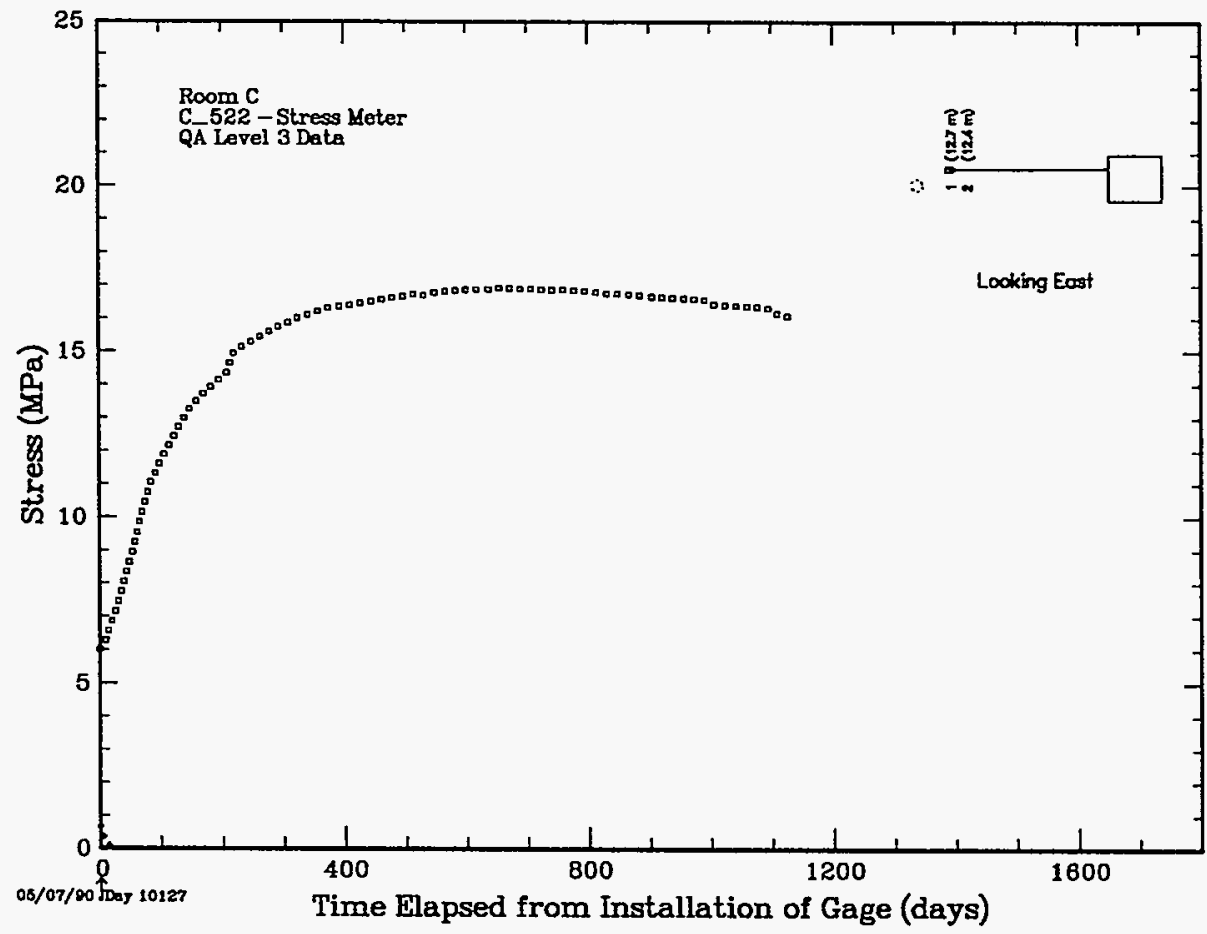

Figure 2.2.2b. Stress Meter SGS Unit C_522 
Table 2.2.2c. Stress Meter SGS Unit C_523

trage:

\#**** C_523 PI Comsents $* * * * *$

09/03/93 TLC:GTB (RANK $=10(1), 9(2)$ ) GAGE -1 AND -2 WERE INSTALLED 210 AND

-2 HAD 18 DAYS OFING OF THE IN BECAUSE OF ACALE BOREHOLE, RESPECTIVELY, GAGE

DAYS OE DATA DELETED BLCAUSE OF AN ERRONEOUS COEFFICIENT. THE RESULIS

AS SHOWN BY THE UNIT AT THAT TIME. [COMPRESSION $2.59: 1$ ] (DEM)

***** C_523 Location *****

Prinelpal station

station

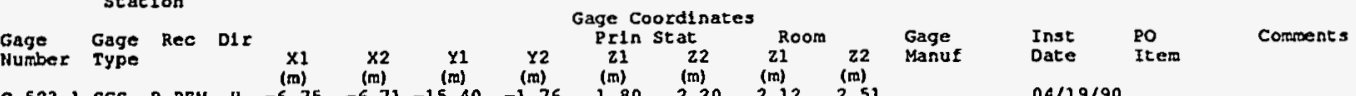

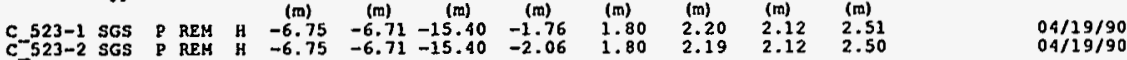

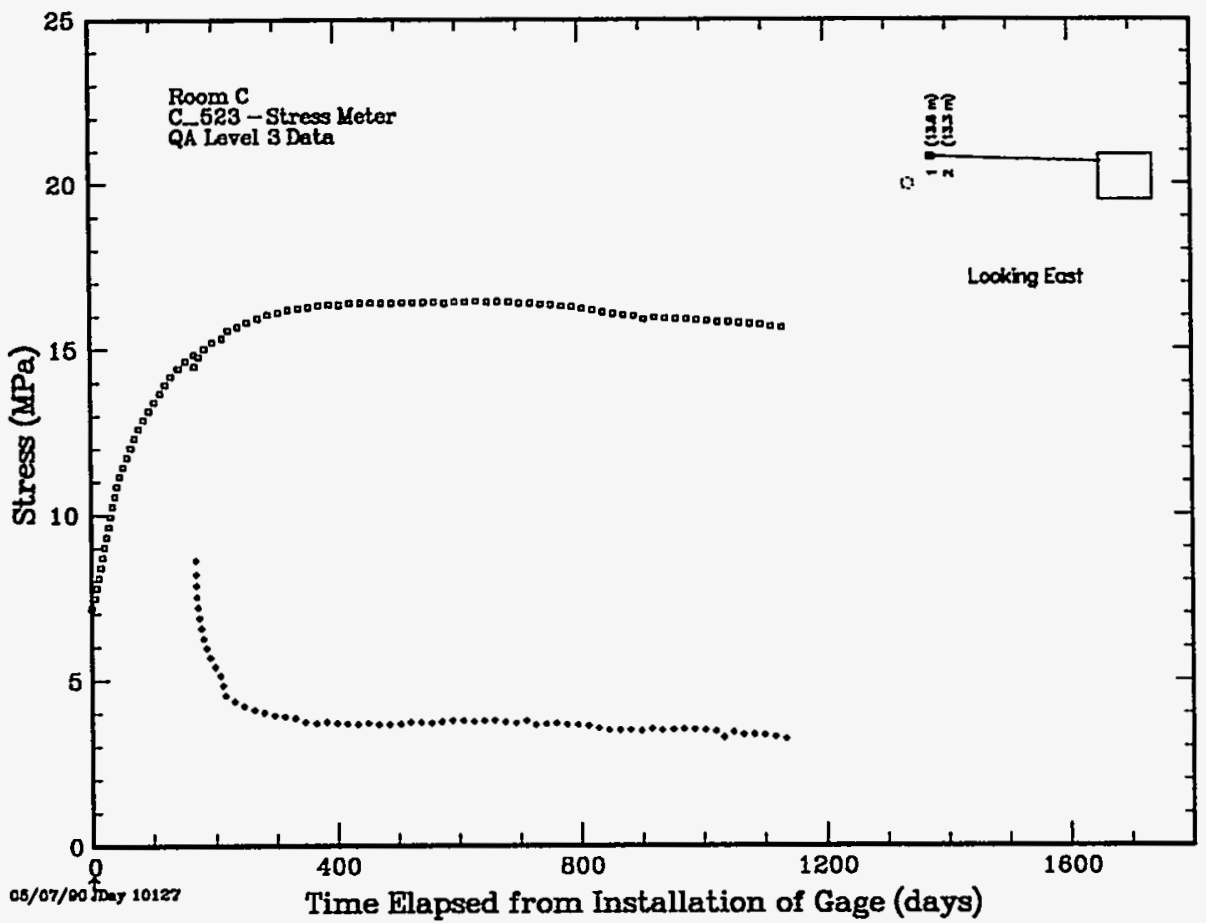

Figure 2.2.2c. Stress Meter SGS Unit C_523

113 
Table 2.2.2d. Stress Meter SGS Unit C_524

\begin{tabular}{|c|c|c|}
\hline I & Gage: & c. 524 \\
\hline
\end{tabular}

An*** C_524 PI Comments $* * * * *$

09/03/93 TLC: GTB (RANK = $10(1), 10(2) 1$ THE DATA FROM THIS UNIT ARE OUTSTANDING.

THIS SGS STRESS UNIT WAS INSTALLED 209 DAYS BEFORE MINING OF THE INTERMEDIATE

SCALE BOREHOLE. VERY LITTLE REDUCTION WAS REQUIREO EXCEPT FOR MINOR DELETION

OF SCATTER. THE RESULTS OF THE MINING CAN BE SEEN STARTING AT DAY 209 WITH
THE PERTURBATION IN STRESS AS SHOWN BY THE UNIT. (COMPRESSION 2.35:1] (DEM)

$x \times x \times$ C_524 Location $\times x \times * *$

Principal station

Station

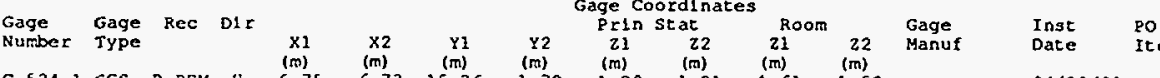

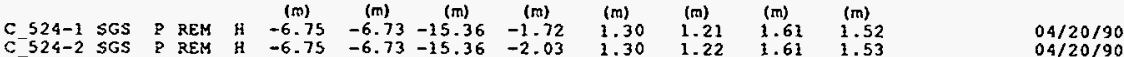

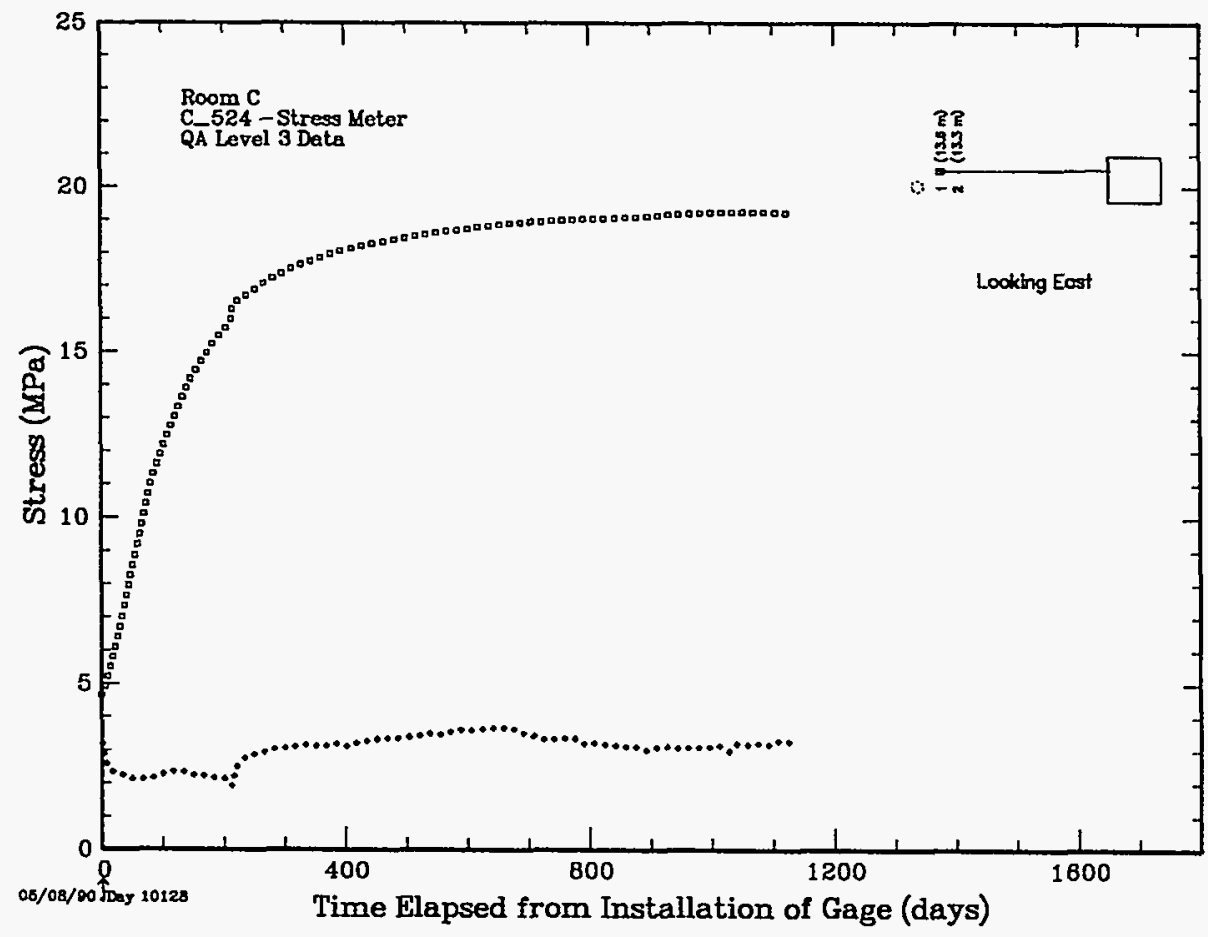

Figure 2.2.2d. Stress Meter SGS Unit C_524 
Table 2.2.2e. Stress Meter SGS Unit C_525

Gage: C_525 |

***** C_525 PI coments $* * * * *$

09/03/93 TLC:GTB [RANK a $10(1), 10(2)]$ THE DATA FROH THIS UNIT ARE CUTSTANDING. THIS SGS STRESS UNIT WAS INSTALLED 209 DAYS BEFORE MINING OF THE INTERMEDIATE SCALE BOREHOLE. VERY LITTLE REDUCTION KAS REQUIRED EXCEPT FOR MINOR DELETION OF SCATTER. THE RESULTS OF THE MINING CAN BE SEEN STARTING AT DAY 209 WITH
THE PERTURBATION IN STRESS AS SHOWN BY SHE UNIT. [COMPRESSION $3.21: 11$ (DEM)

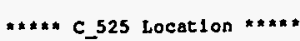

Prlncipal station Station

Gage Coordinates

Gage Gage

Rec $01 x$

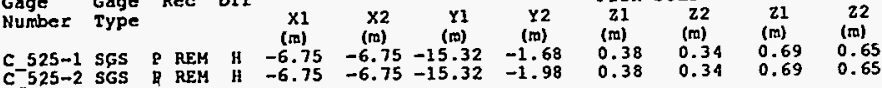

Gage Inst Po

comrents

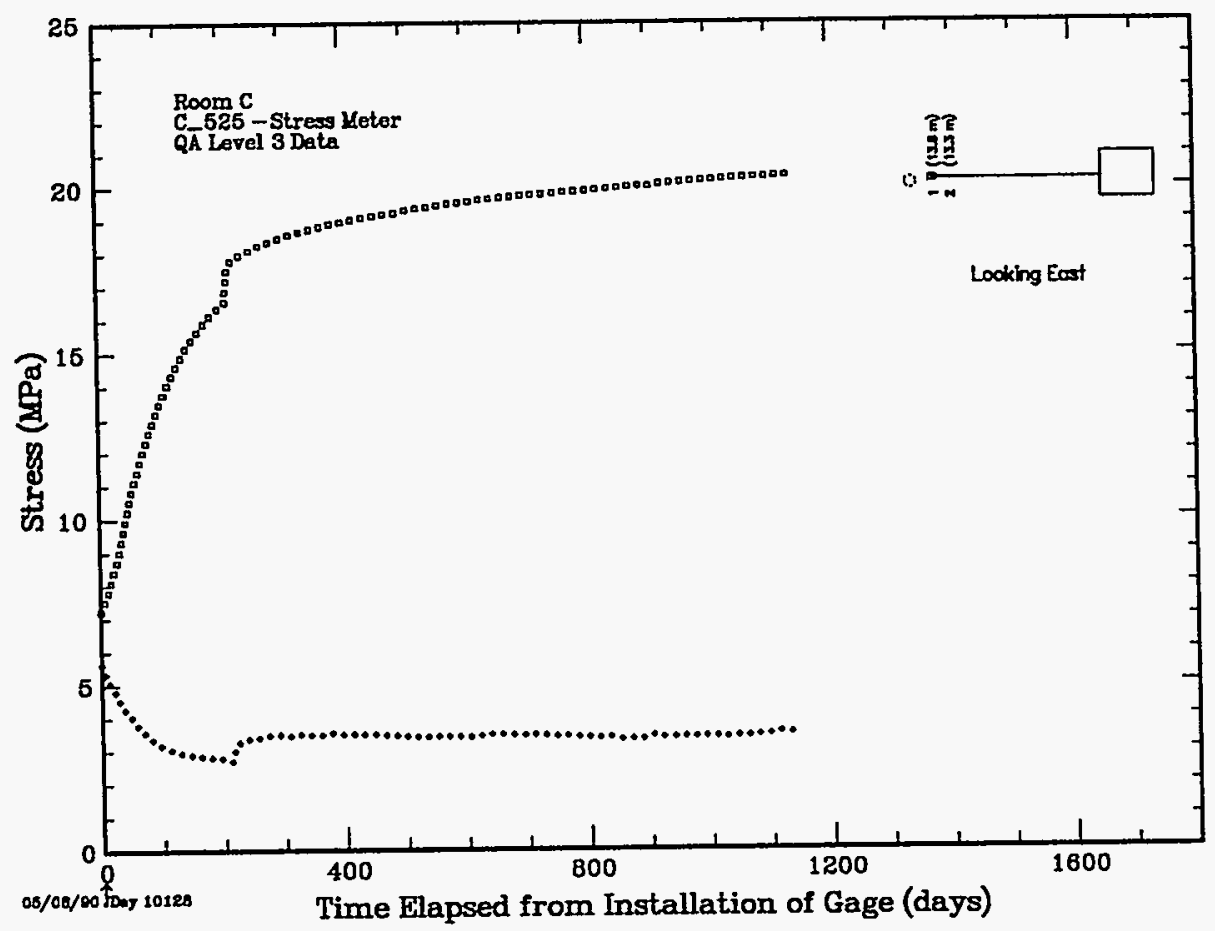

Figure 2.2.2e. Stress Meter SGS Unit C_525

115 
Table 2.2.2f. Stress Meter SGS Unit C_526

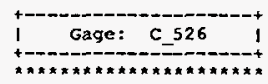

***** C_526 PI Coments **A**

09/03/93 TLC:GTB [RANK $=10(1), 10(2)]$ THE DATA FROM THIS UNIT ARE CO'TSTANDING.

THIS SGS STRESS UNIT WAS INSTALLED 182 DAYS BEFORE MINING OF THE INTERMEDIATE

SCALE BCRERESS UHERY LIT INLE REDUCTON WAS NECESSARY EXCEPT EOR MINOR DELETION

OF SCATTER. THE RESULTS OF THE MINING CAN BE SEEN STARTING AT DAY 182 KITH THE
PERTURBATION IN STRESS AS SHCWN BY THE UNIT. (COMPRESSION $2.91: 1$ (DEM)

*Ax* C 526 Location *m***

Princtpal station

Station

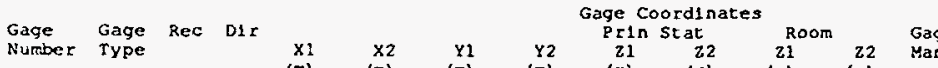

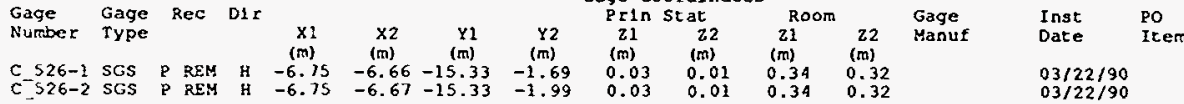

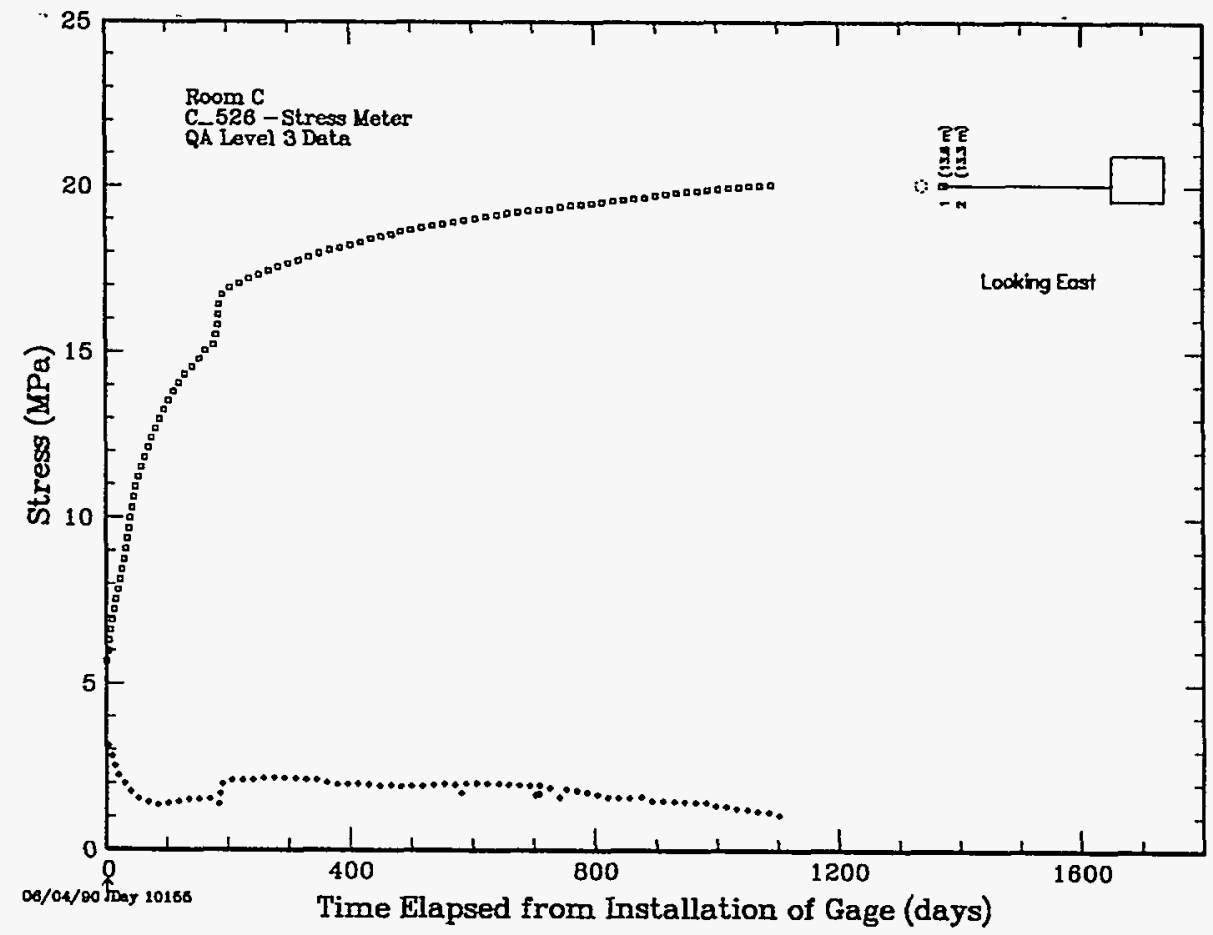

Figure 2.2.2f. Stress Meter SGS Unit C_526 
Table 2.2.2g. Stress Meter SGS Unit C_531

I Gage: Cs531

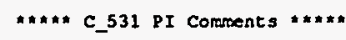

09/03/93 ILC:GTB [RANK $=10(1), 10(2)$ ] THE DATA FROM THIS UNIT ARE CUTSTANDING. THIS SGS STRESS UNIT WAS INSTALLED 209 DAYS BEFORE MINING OF THE INTERMEDIATE SCALE BOREHOLE. VERY LITTLE REDUCTION WAS PERFORHED EXCEPT FOR MINOR DELETION OF SCATTER. THE RESULTS OF THE MINING CAN BE SEEN STARIING AT DAY 209 WITH THE
PERTURBATION IN STRESS AS SHOWN BY THE UNIT. [COMPRESSION 1.60:1] (DEM)

***** C_531 Location ******

Principal station Station

Gage Coordinates

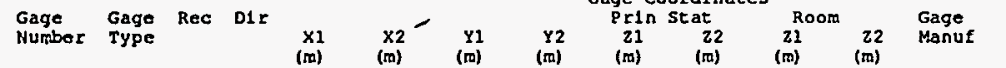

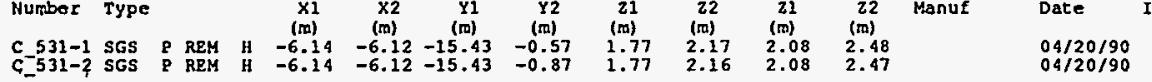

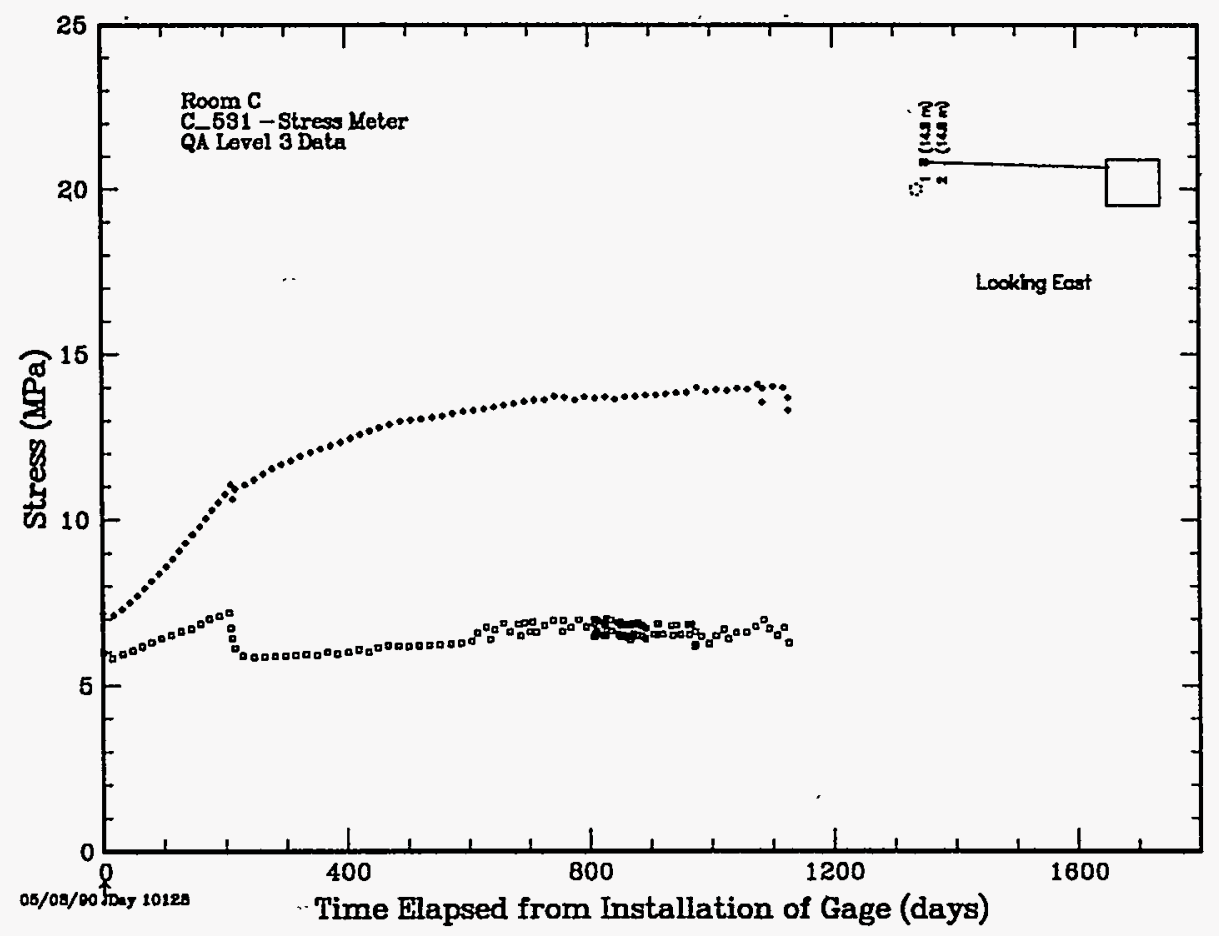

Figure 2.2.2g. Stress Meter SGS Unit C_5:31 
Table 2.2.2h. Stress Meter SGS Unit C_532
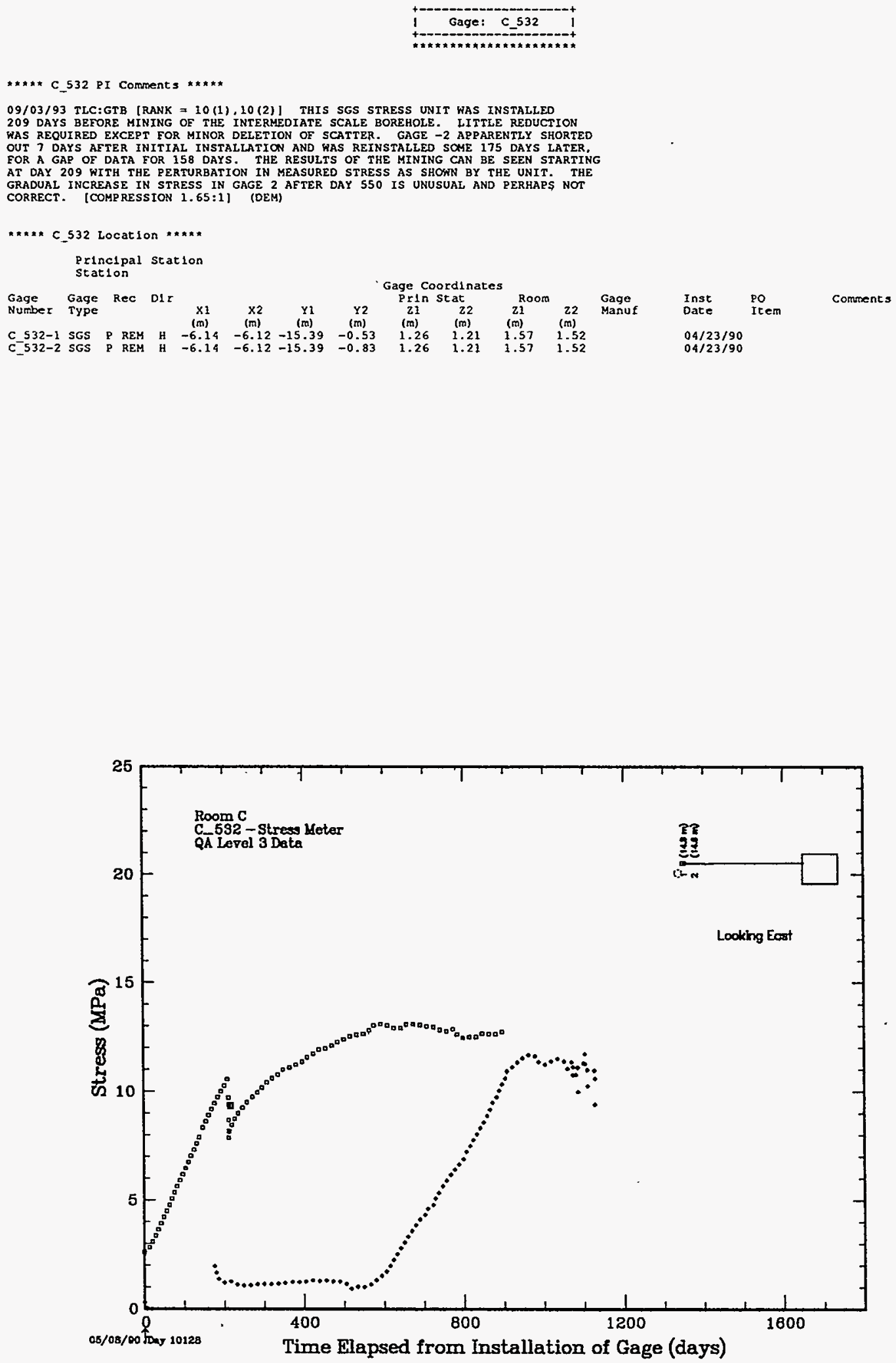

Figure 2.2.2h. Stress Meter SGS Unit C_532 
Table 2,2.2i. Stress Meter SGS Unit C_533

Gage: c_533

$\star * \pi * *$ C_533 RI Corments $* \star * \star *$

09/03/93 TLC: GTB [RANK $=10(1), 10(2)$ ] THE DATA FROH THIS UNIT ARE OUTSTANDING. THIS SGS STRESS UNIT WAS INSTALLED 210 DAYS BEFORE MINING OF THE INTERMEDTATE SCALE BOREHOLE. VERY LITTLE REDUCTION RAS REQUIREO EXRT OF SCATTER. THE RESULTS OF THE HINING CAN BE SEEN STARTING AT DAY 210 WM
(DEM)

***** C 533 Location $* * * * *$ Principal station
Ecation

Gage Coordinates

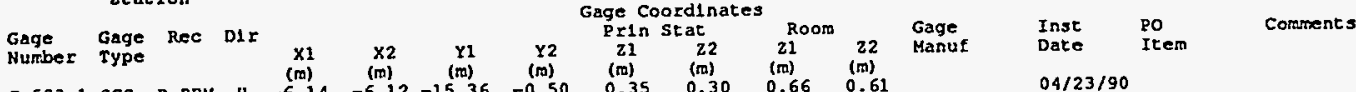

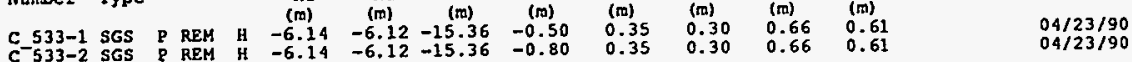

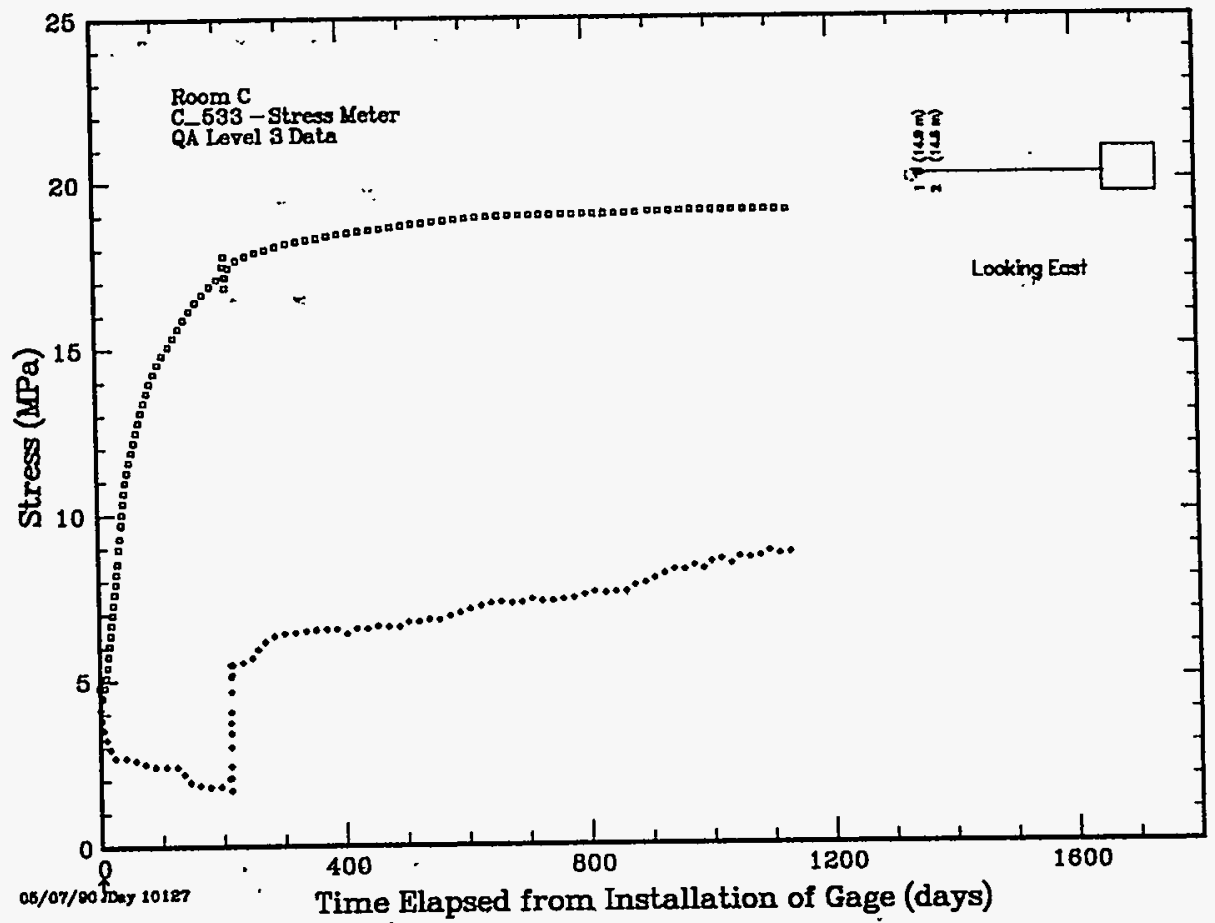

Figure 2.2.2i. Stress Meter SGS Unit C_533 
Table 2.2.2j. Stress Meter SGS Unit C_534

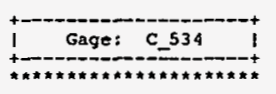

\#**** C.534 PI Comments $* * * * *$

09/03/93 TLC: GTB [RANK $=10(1), 10(2)$ ] THE DATA FROM THIS UNLT ARE OUTSTANDING THIS SGS STRESS UNIT WAS INSTALLED 182 DAYS BEFORE MINING OE THE INTERMEQTATE BCESSARY EXCEPT EOR MINO

D291) AETER THE INITIAL INSTALIATION

THE RESULTS OE THE MINING CAN BE SEEN STARTING AT DAY 182 WITH THE PERTURBATION
IN STRESS AS SHOWN BY THE UNFT. [COMPRESSION 2.12:1] (DEM)

***** C_534 Location *****

Princlpal station
Station

$$
\text { stacton }
$$

Gage Coordinates

Gage Gage Rec $01 x$

$\begin{array}{lllll}\text { Number Type } & X 1 & X 2 & Y 1 & Y 2 \\ (m) & (m) & (m) & (m) \\ (m) & (m) & (m) & \end{array}$

21 Stat 22 Room 22 Gage

$\begin{array}{llll}(m) & (m) & (m) & (m) \\ 0.00 & 0.10 & 0.31 & 0.41\end{array}$

Inst po

Comsrents

$\begin{array}{lllllll}C & 534-2 & \text { SGS } P \text { REM } H & -6.14 & -6.19 & -15.35 & -0.80\end{array}$

$$
\begin{array}{llll}
.00 & 0.10 & 0.31 & 0.41
\end{array}
$$

$05 / 22 / 90$
$05 / 22 / 90$

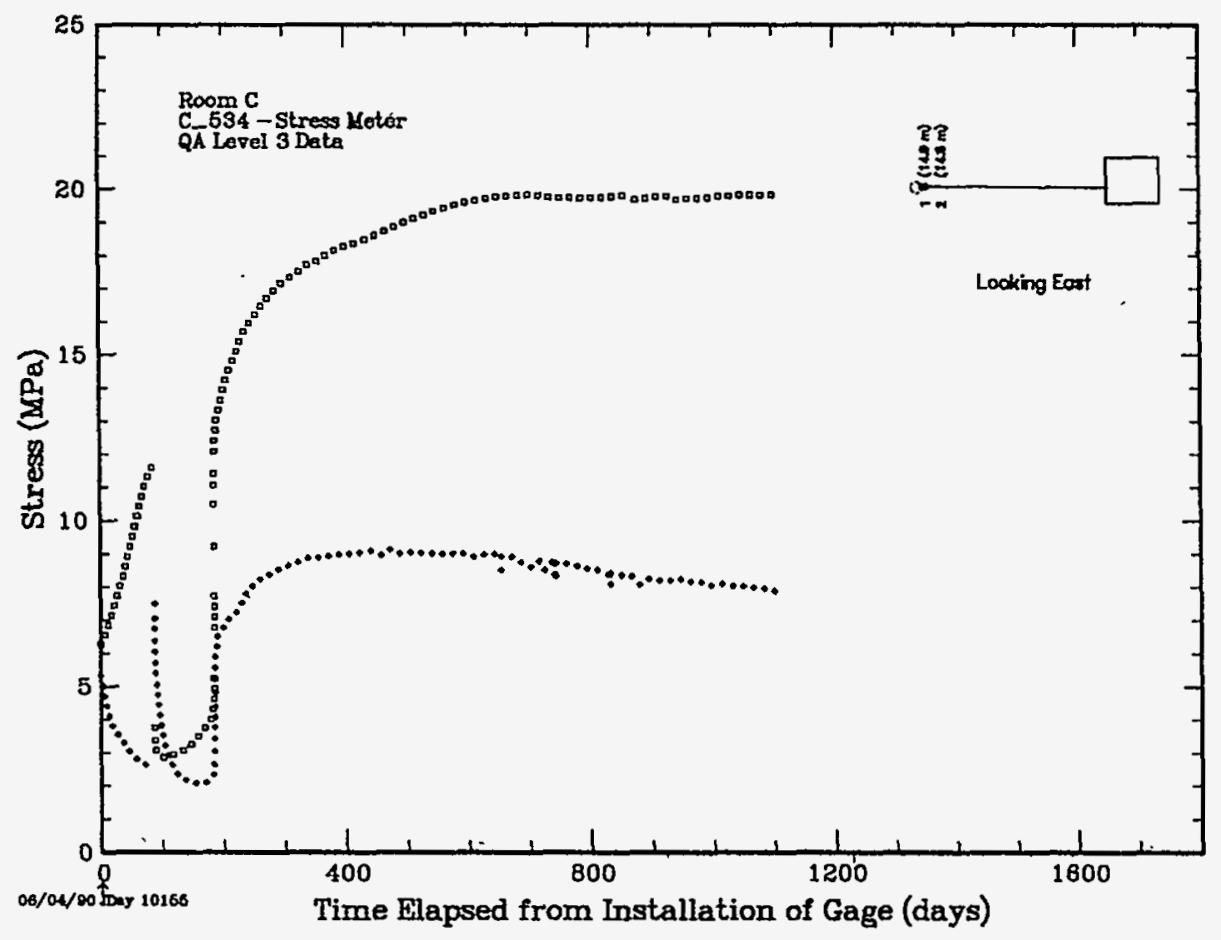

Figure 2.2.2j. Stress Meter SGS Unit C_534 
Table 2.2.2k. Stress Meter SGS Unit C_561

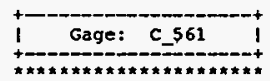

A**** C 561 PI Comrents *****

09/03/93 TLC:GTB [RANK $=10(1), 10(2)$ ] THE DATA FROM THIS UNIT ARE QUTSTANDING. THIS SGS STRESS UNIT WAS INSTALLED 209 DAYS BEFORE MINING OF THE INTERHEDIATE

SCALE BOREHOLE, VERY LIITLE REDUCTION MAS REQUIRED EXCEPT FOR MINOR DELETION

$* * * * *$ C_561 Location $* * * * *$

Principal station Station

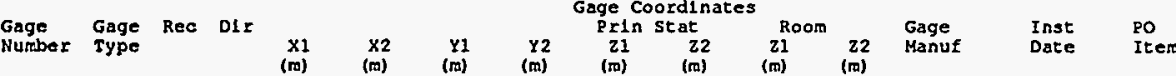

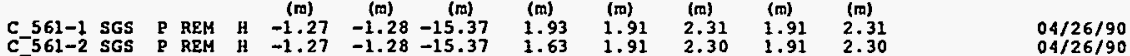

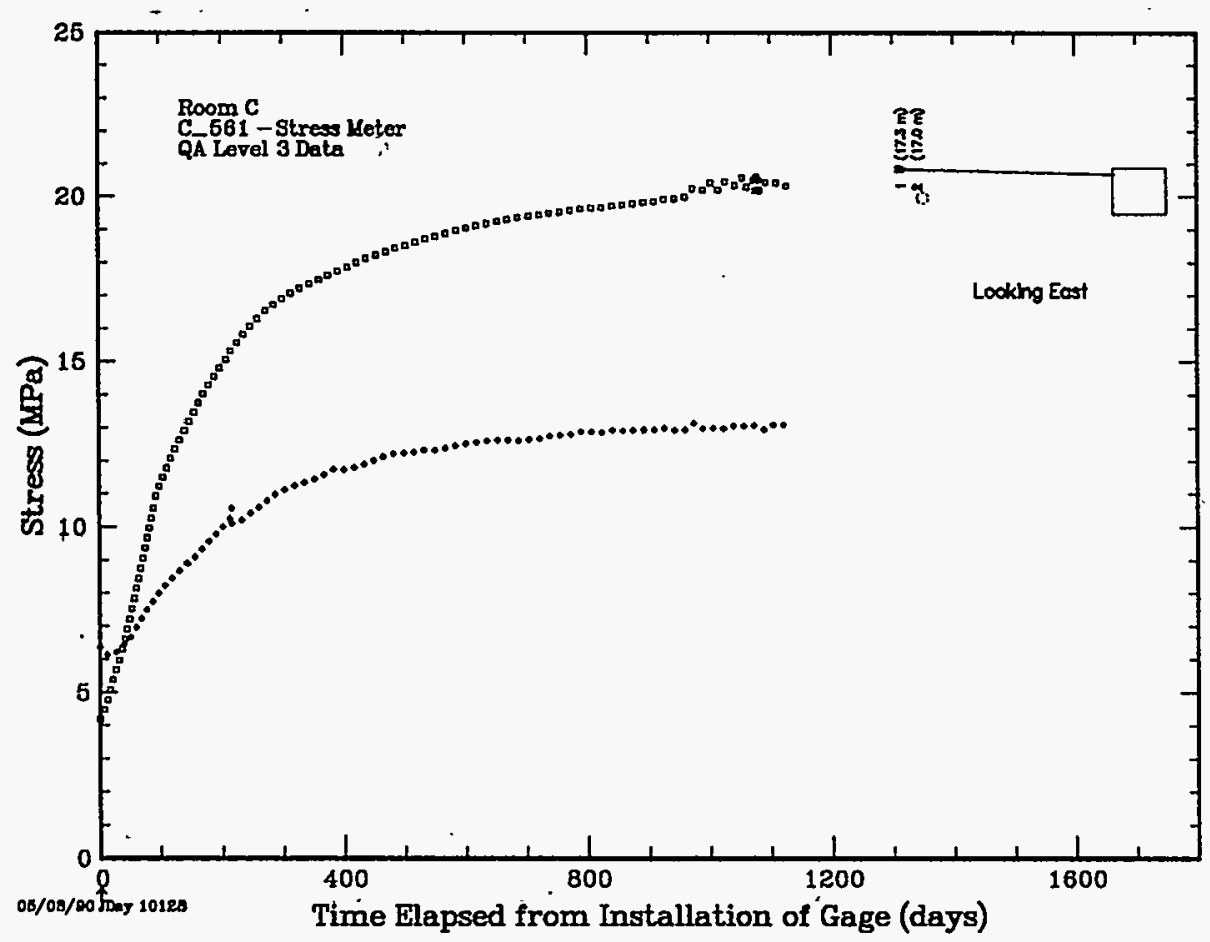

Figure 2.2.2k. Stress Meter SGS Unit C_561 
Table 2.2.21. Stress Meter SGS Unit C_562

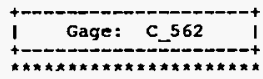

**** C_562 81 Comments *****

09/03/93 TLC:GTB [RANK $=10(1), 10(2)$ ] THE DATA FROM THIS UNIT ARE OUTSTANDING. THIS SGS STRESS UNIT HAS INSTALLED 209 DAYS BEFORE HINING OF THE INTERMEDIATE SCALE BOREHOLE. VERY LITTLE REDUCTION WAS NECESSARY EXCEPT FOR MINOR DELETION
OF SCATTER. THE RESUETS OF THE MINING CAN BE SEEN STARTING AT DAY 209 WITH THE OF SCATTER. THE RESUETS OF THE MINING CAN BE SEEN STARTING AT DAY 209 TITH THE
PERTURBATION IN STRESS AS SHOHN BY THE UNIT. AS HAPPENS IN OTHER UNITS, THERE

IS A GRADUAL INCREASE IN STRESS READING IN GAGE - 2 LATE IN THE RECORD, HERE

IS A GRADUAL INCREASE IN STRESS READING IN GAGE -2 LATE IN THE RECORD,
AETER ABOUT DAY 925. THE CAUSE IS UNKNONN. [COMPRESSION 2.04:1] (DEM)

****** C_562 Location *****

Principal station station

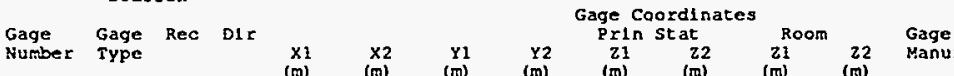

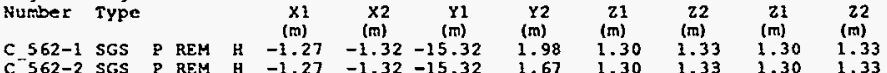

Inst Po comments

$\begin{array}{lllllllllllll}\text { C_562-1 SGS } & \text { P REM } & \text { H } & -1.27 & -1.32 & -15.32 & 1.98 & 1.30 & 1.33 & 1.30 & 1.33 & 04 / 26 / 90 \\ C_{-}^{-562-2} \text { SGS } & \text { P REM } & \text { H } & -1.27 & -1.32 & -15.32 & 1.67 & 1.30 & 1.33 & 1.30 & 1.33 & 04 / 26 / 90\end{array}$

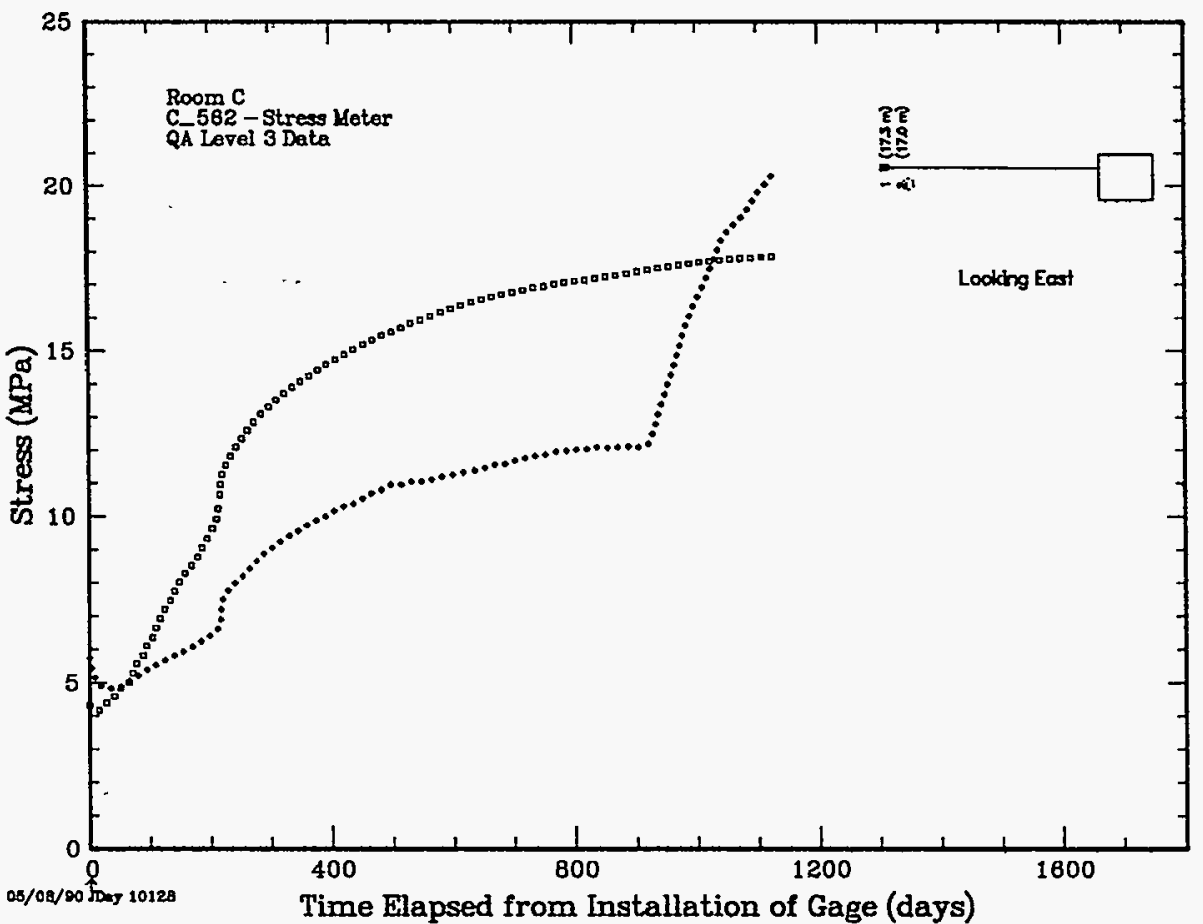

Figure 2.2.21. Stress Meter SGS Unit C_562 
Table 2.2.2m. Stress Meter SGS Unit C_563

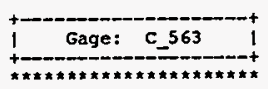

\#**** C_563 PI Compents *****

$09 / 03 / 93$ TLC:GTB [RANK $=10(1), 10(2)$ ] THE DATA FROM THIS UNIT ARE OUTSTANDING. THIS SGS STRESS UNIT WAS INSTALLED 209 DAYS BEFORE MINING OF THE INTERMEDIATE SCALE BOREHOLE. VERY LITTLE REDUCTION KAS NECESSARY EXCERT FOR MINOR DELETYON OF SCATTER. THE RESUES OF

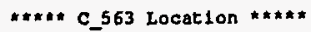

\section{Principal starion} searion

Gage Gage Rec Dis

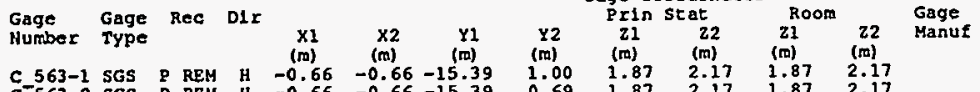

C-563-2 SGS P REM H $\begin{array}{lllllllll} & -0.66 & -0.66 & -15.39 & 0.69 & 1.87 & 2.17 & 1.87 & 2.17 \\ \end{array}$

$\begin{array}{ll}\text { Inst } & \text { Po } \\ \text { Date } & \text { Item }\end{array}$ $04 / 26 / 90$
$04 / 26 / 90$

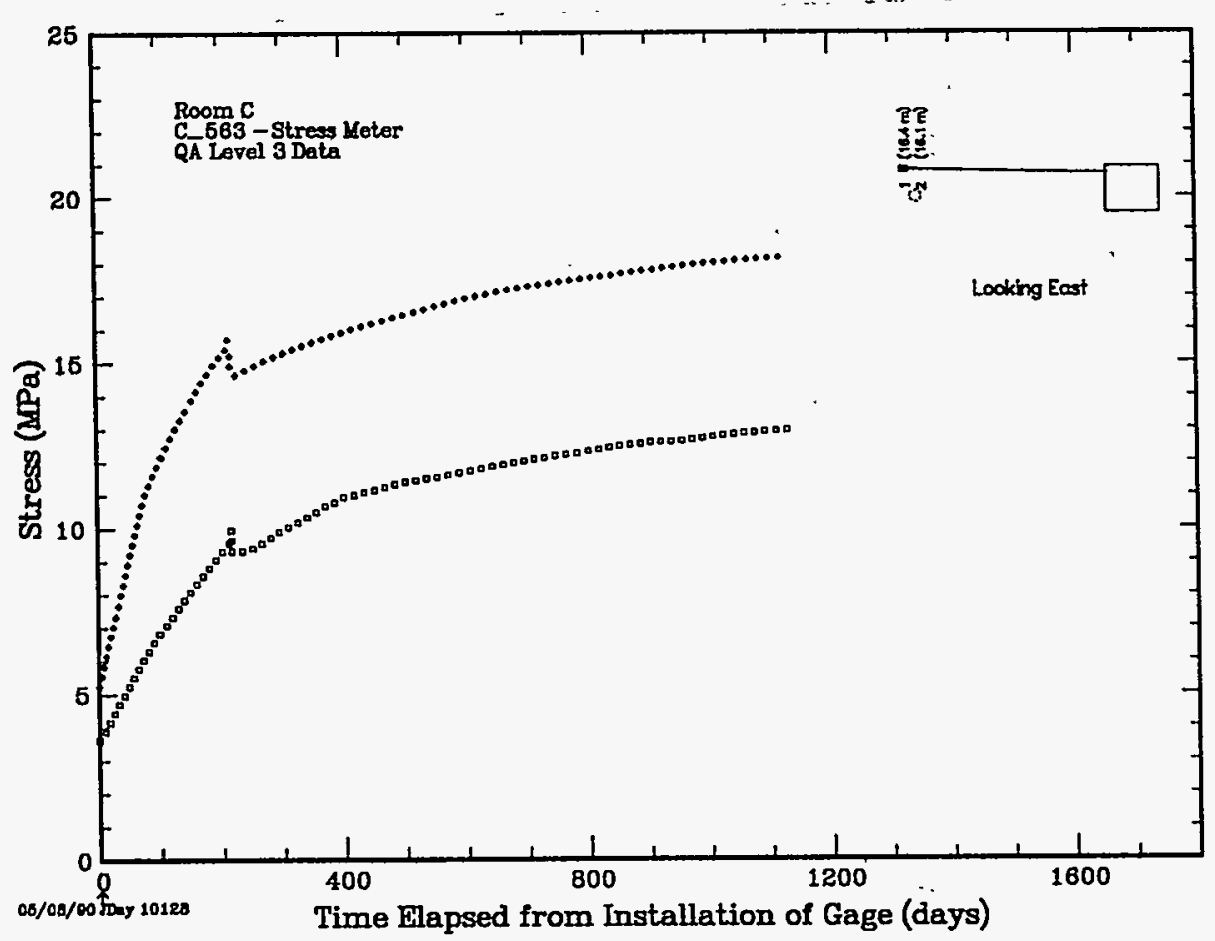

Figure 2.2.2m. Stress Meter SGS Unit C_563 
Table 2.2.2n. Stress Meter SGS Unit C_564

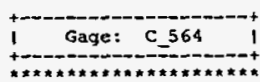

$* * * * C_{-} 564$ PI Comments $* * * * *$

09/03/93 TLC:GTB [RANK $=10(1), 10(2)$ ) THE DATA FROM THIS UNIT ARE OUTSTANDING.

THIS SGS STRESS UNIT NAS INSTALLED 209 DAYS BEFORE MINING OF THE INTERMEDIATE

DELETION OF SCATTER. THE RESULTS OF THE MINING CAN BE SEEN STARTING AT DAY 209

WITH THE PERTURBATION IN MEASURED STRESS AS SHOWN BY THE UNIT AT THIS TIME.

[COMPRESSION 2.52:1] (DEM)

***** C_564 Location *****

Principal station
Station

Gage Gage Rec D1r Gage Coordinates

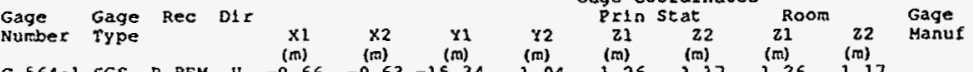

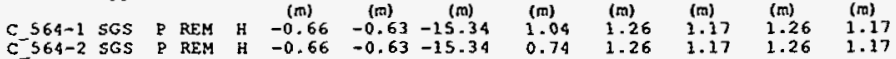

Inst po

$04 / 26 / 90$

$04 / 26 / 90$
$04 / 26 / 90$

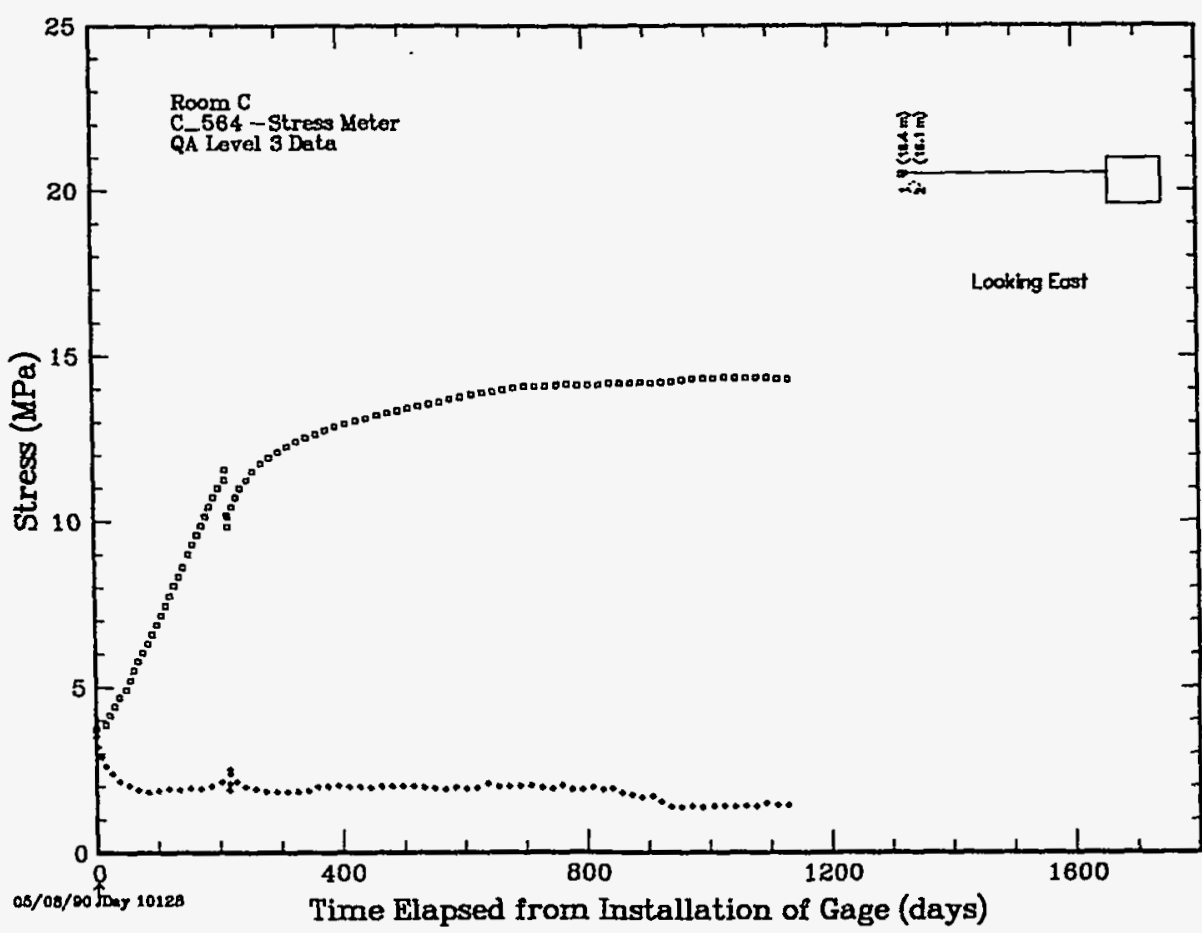

Figure 2.2.2n. Stress Meter SGS Unit C_564 
Table 2.2.20. Stress Meter SGS Unit C_565

tome: c_565 |

***** C_565 PI Corments ******

$06 / 03 / 92$ TLC (RANK $=10(1), 10(2)$ | THIS SGS STRESS UNIT WAS INSTALLED 209 DAYS COU DOAL BOREHOLE. THE TRANSDUCER LEADS TO THE . [COMPRESSION 1.97:1] (DEM)

$* * * * *$ C_565 Location $* * * * * *$

Principal station station

Gage Gage Rec D1r

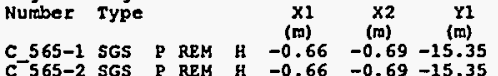

\begin{tabular}{cccccccc}
\multicolumn{7}{c}{ Gage Coordinates } \\
Yrin Stat & R1 & Room & Z1 & G2 & Gage & Inst & PO \\
Yanuf & Date & Iten \\
(m) & (m) & (m) & (m) & (m) & & \\
1.03 & 0.35 & 0.44 & 0.35 & 0.44 & & $04 / 27 / 90$ \\
0.73 & 0.35 & 0.44 & 0.35 & 0.44 & & $04 / 27 / 90$
\end{tabular}

Coments

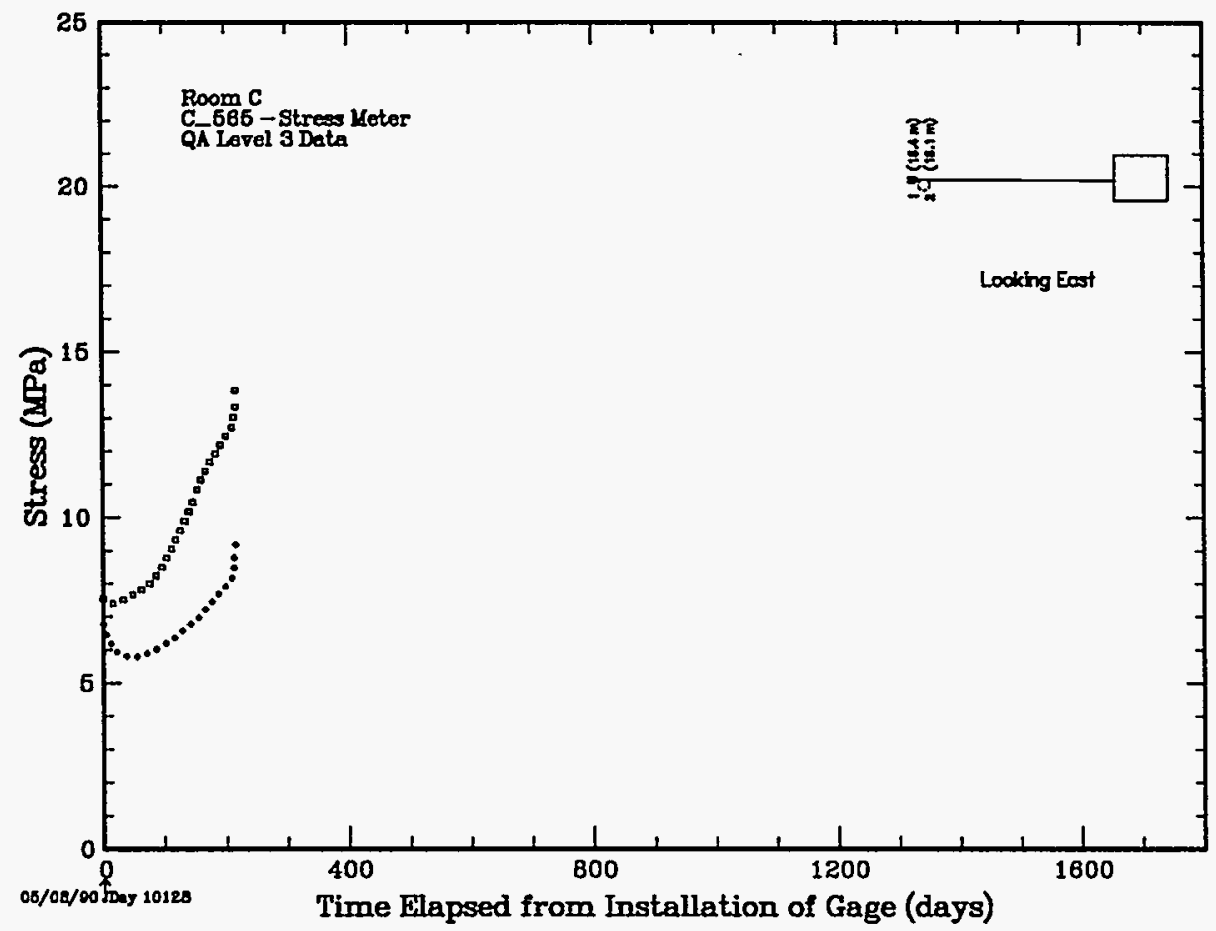

Figure 2.2.20. Stress Meter SGS Unit C_565 
Table 2.2.2p. Stress Meter SGS Unit C_566

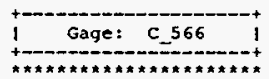

*...* C S66 PI Coments *****

09/03/93 TLC; GTB [RANK $=10(1), 10(2)]$ THE DATA FROM THIS UNIT ARE OUTSTANDING. THIS SGS STRESS UNIT WAS INSTALEED 60 DAYS BEEORE MINING OF THE INTERMEDIATE SCALE BOREHOLE. VERY LITTLE REDUCTION WAS NECESSARY EXCEPT FOR MINOR DELETION OF SCATTER. THE RESULTS OF THE MINING CAN BE SEEN STARTING AT DAY 60 WITH THE

$\ldots * * *$ C 566 L,ocation $* * * * *$

Principal station

station

Gage Gage Rec D15

$\begin{array}{cccc} & & & \\ X 1 & X 2 & Y 1 & Y 2 \\ (m) & (m) & (m) & (m) \\ -0.66 & -0.73 & -15.37 & -0.74 \\ -0.66 & -0.73 & -15.37 & -1.05\end{array}$

Gage Coordinates

Prin Stat Room Gage

$\begin{array}{lllllllllllll}\text { CSS66-1 } & \text { SGS } & \text { P REM } & \text { H } & -0.66 & -0.73 & -15.37 & -0.74 & 0.00 & 0.01 & 0.00 & 0.01 \\ \text { c-S66-2 } & \text { SGS } & \text { \& } & R E M & \text { H } & -0.66 & -0.73 & -15.37 & -1.05 & 0.00 & 0.01 & 0.00 & 0.01\end{array}$

$\begin{array}{ll}\text { Inst } & \text { PO } \\ \text { Date } & \text { Item }\end{array}$

Coment s

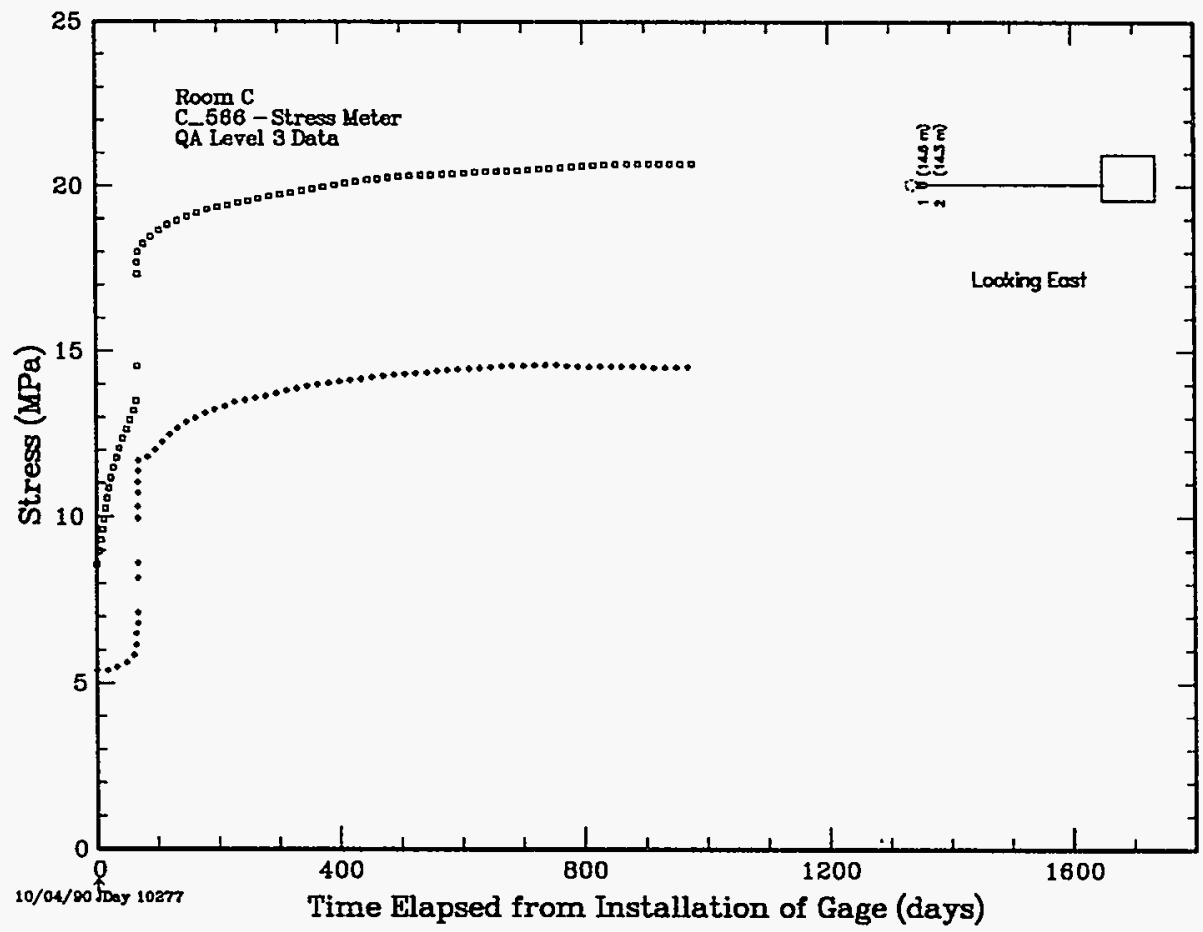

Figure 2.2.2p. Stress Meter SGS Unit C_566 
Table 2.2.2q. Stress Meter SGS Unit C_571

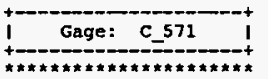

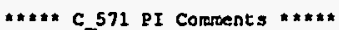

09/03/93 TLC:GTB [RANK $=10$ (1), 10 (2)] THE DATA FROM THIS UMIT ARE OUTSTANDING. THIS SGS STRESS UNIT YAS INSTALIED 209 DAYS BEFORE MINING OF THE INTERMED IATE SCALE BOREHOLR. VERY LITTLE REDUCTION WAS NECESSARY EXCEPT FOR MINOR DELETTON OF SCATTER. THE RESULTS OE THE MINING CAN BE SEEN STARTING AT DAY 209 WITH THE

***** C_571 Location *****

Principal station Station

Gage Gage Rec D1r Gage Coordinates

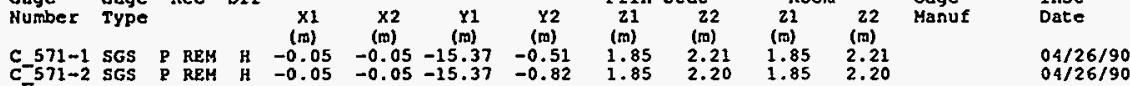

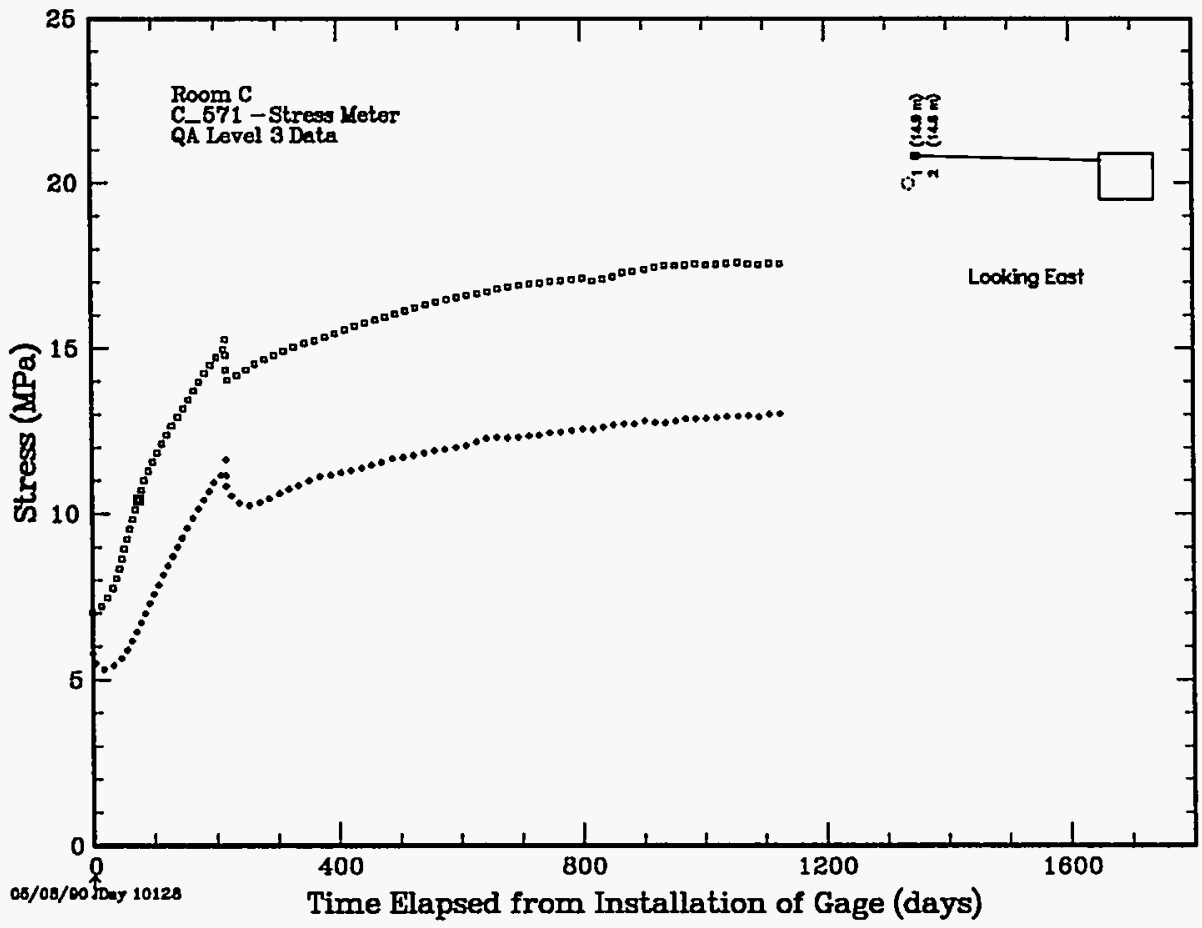

Figure 2.2.2q. Stress Meter SGS Unit C_571 
Table 2.2.2r. Stress Meter SGS Unit C_572

|
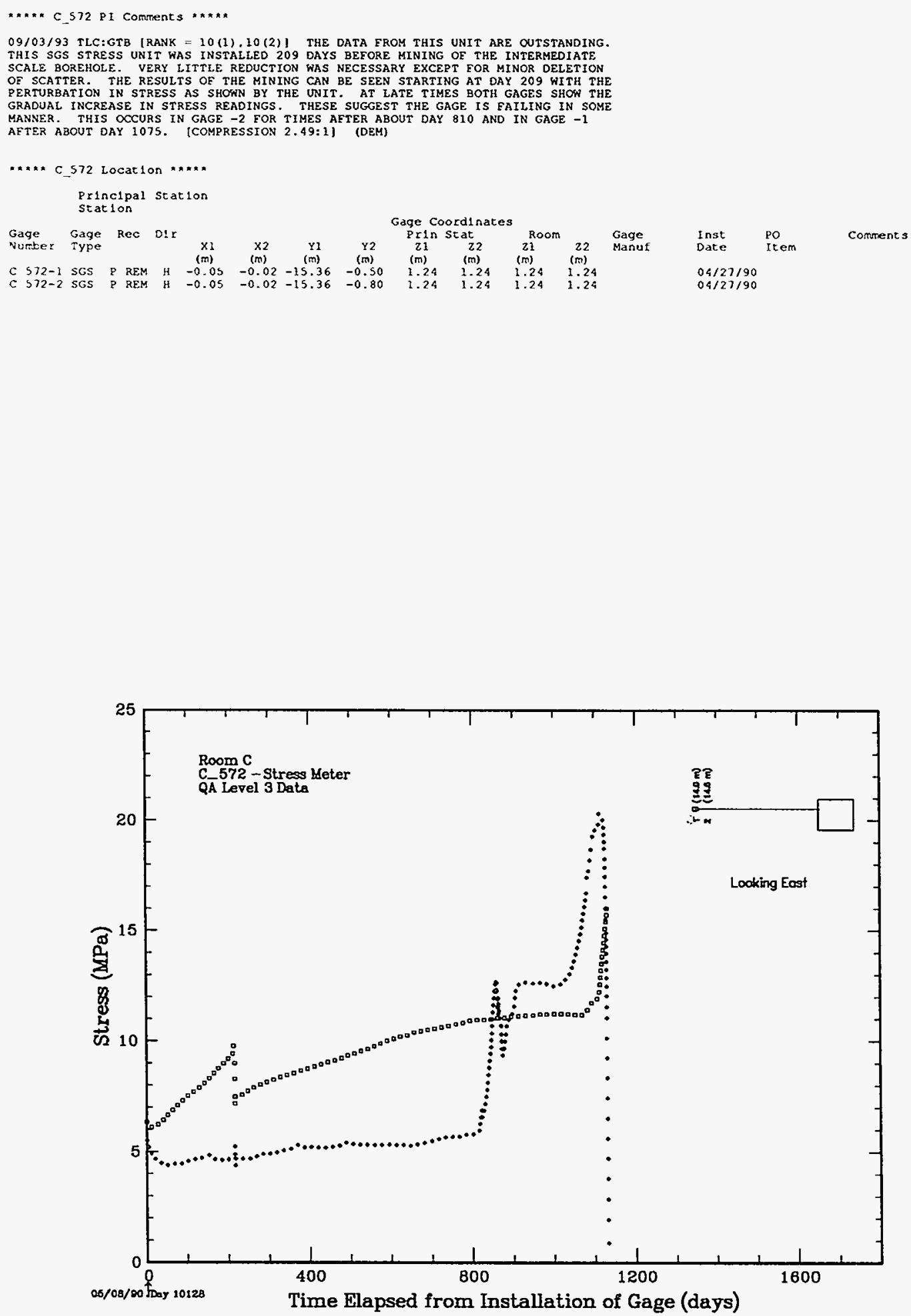

Figure 2.2.2r. Stress Meter SGS Unit C_572 
Table 2.2.2s. Stress Meter SGS Unit C_573

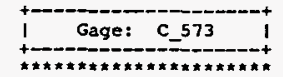

***n* C_573 PI Comments *****

09/03/93 TLC: GTB [RANK $=10(1), 10(2)]$ THE DATA FROM THIS UNIT ARE OUTSTANDING. SCALE BOREHOLE UNIT WAS INSTALLLED 209 DAYS BEEORE MINING OF THE INTERMEDIATE

OE SCATTER. THE RESULTS OF THE HINING CAN BE SEEN STARTING AT DAY 209 GTTH THE

PERTURBATION IN STRESS AS SHONN BY THE UNIT. (COMRESSION 2.70:1) (DEM)
(DIT IHE

***** C_573 Location "*w**

Principal station

station

Gage Gage ReC Dir

Gage Coordinates

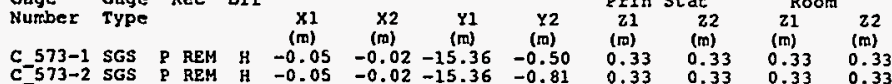

Prin stat Room

Gage Inst Po coments

Date Irem

$04 / 27 / 90$
$04 / 27 / 90$

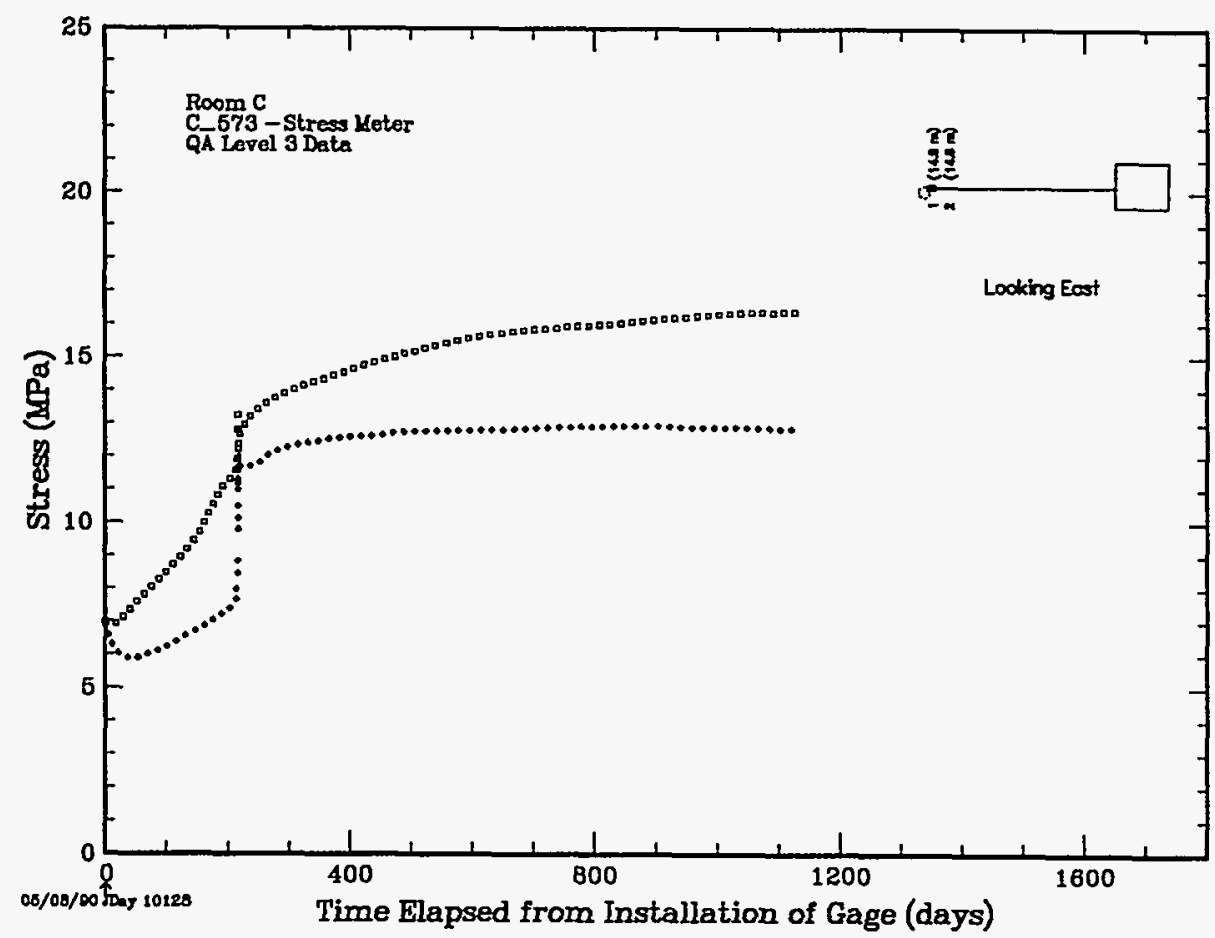

Figure 2.2.2s. Stress Meter SGS Unit C_573 
Table 2.2.2t. Stress Meter SGS Unit C_574

\begin{tabular}{|c|c|c|}
\hline 1 & Gage: & C 574 \\
\hline
\end{tabular}

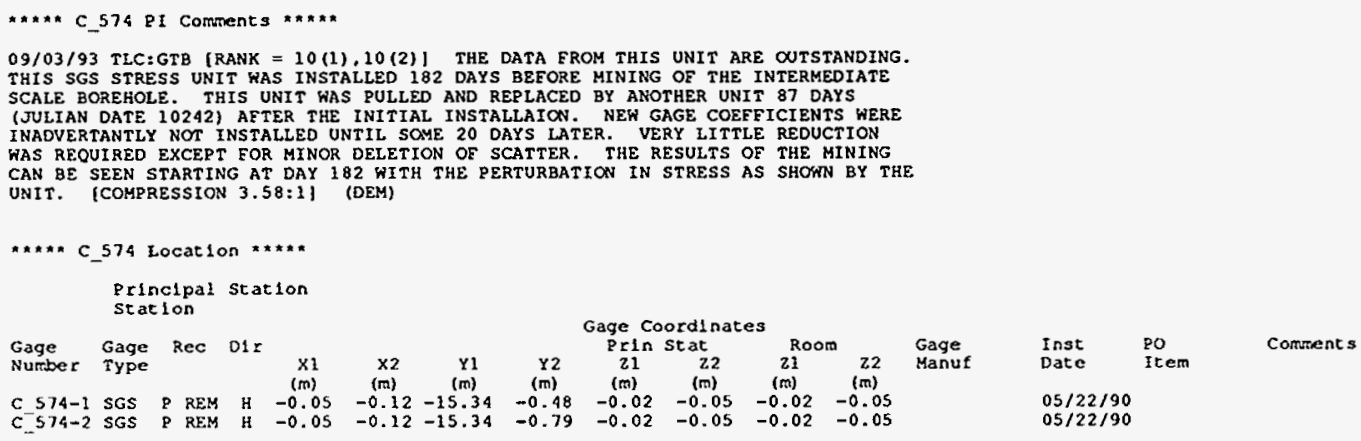
09/03/93 TLC: GTB (RANK $=10(1), 10(2) 1$ THE DATA FROM THIS UNIT ARE OUTSTANDING.
THIS SGS STRESS UNIT WAS INSTALLED 182 DAYS BEFORE MINING OF THE INTERMEDIATE SCALE BOREHOLE. THIS UNIT WAS PULLED AND REPLACED BY ANOTHER UNIT 87 DAYS (JULLAN DATE 10242) AFTER IHE INITIAL INSTALLAICN. NEW GAGE COEFFICIENTS WERE INADVERTANTLY NOT INSTALIES ONTIL SOME 20 DAYS LATER. CAN BE SEEN STARTING AT DAY 182 WITH THE PERTURBATION IN STRESS AS SHOFN BY THE UNIT. [COMPRESSION 3.58:1] (DEM)

**** C_574 Lccation $* * * * *$ Princlpal station Station

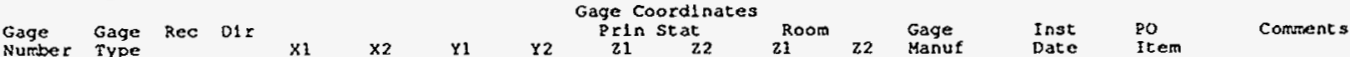

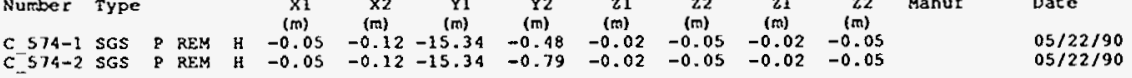

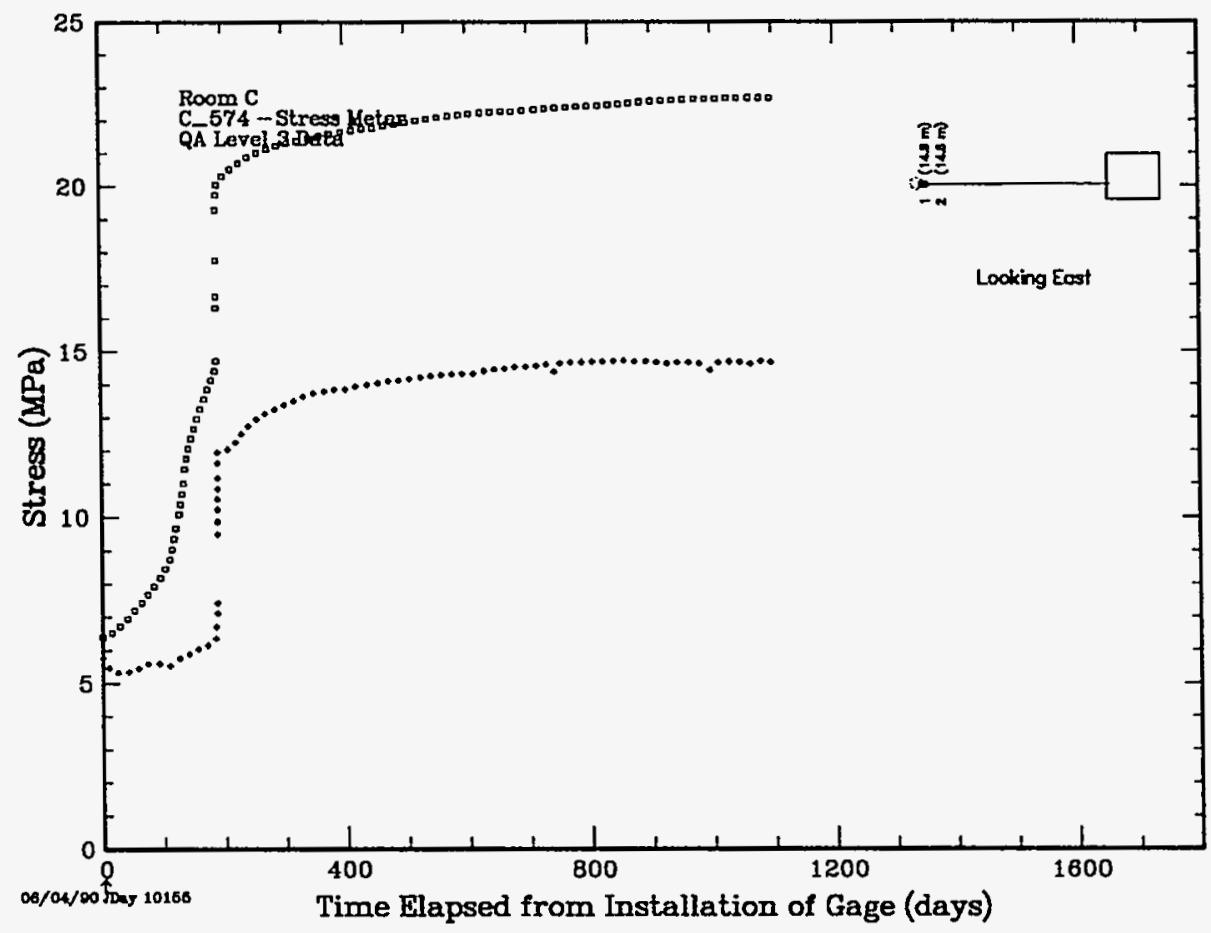

Figure 2.2.2t. Stress Meter SGS Unit C_574 
Table 2.2.2u. Stress Meter BuMines Unit C_641

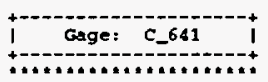
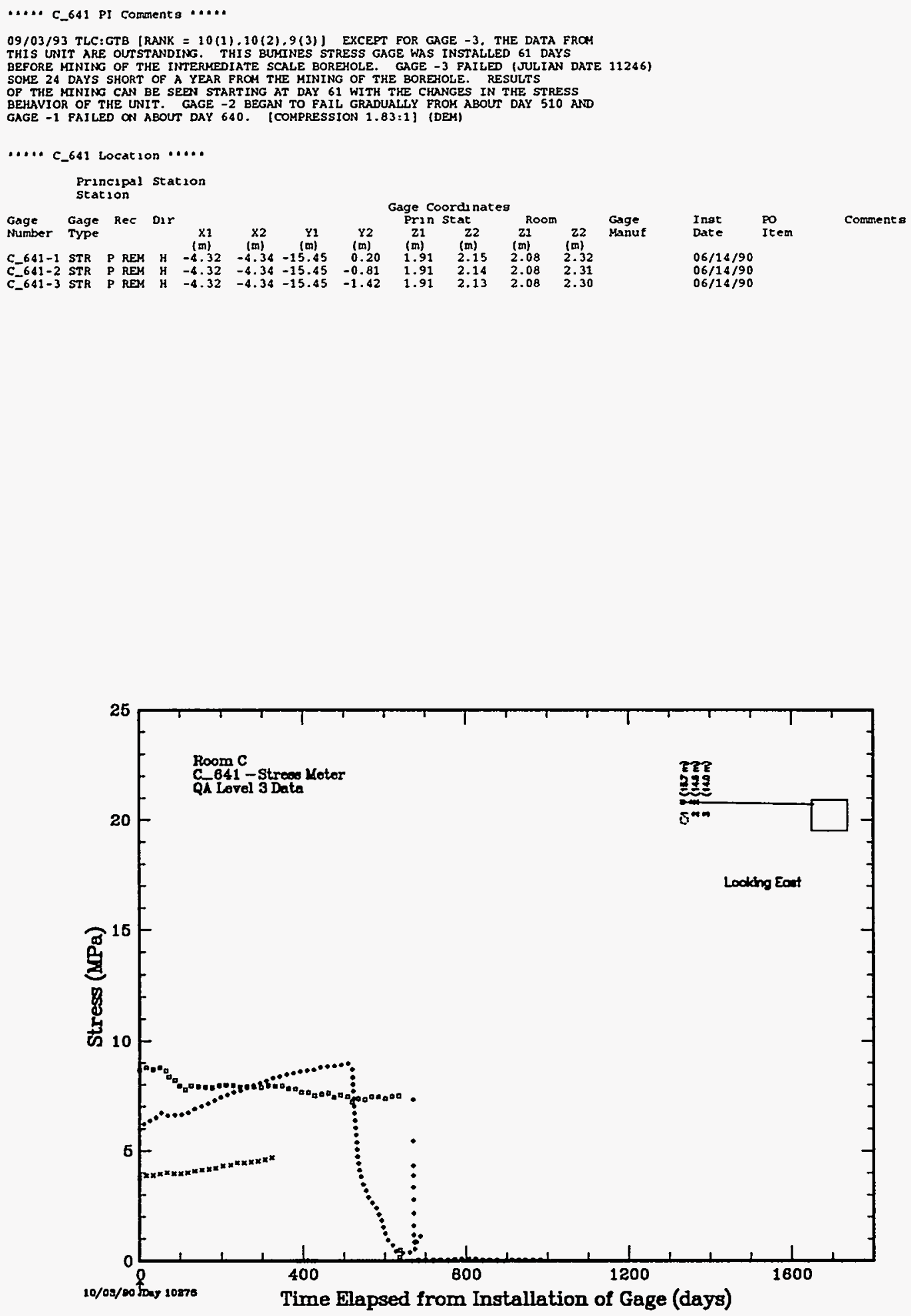

Figure 2.2.2u. Stress Meter BuMines Unit C_641 
Table 2.2.2v. Stress Meter BuMines Unit C_642

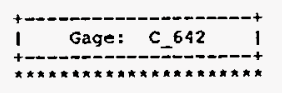

***a* C_642 PI. Comsents **a**

$09 / 03 / 93$ TIC: GTB [RANK $=10(1), 10(2), 10(3)$ ] DATA OF THIS UNIT ARE CUTSTANDING.

THIS BUMINES STRESS GAGE WAS INSTALLED 54 DAYS BEFORE START OF MINING OF THE

INTRT

STARTING AT DAY 54 WITH MARKED CHANGES IN THE STRESS BEHAVIOR OF THE UNIT.

GAGE -2 FAILED RAPIDLY ABOUT DAY 360 . [COMPRESSION $2.04: 1]$ (DEM)

A**x* C_642 Location *n*n*

$$
\text { Princlpal station }
$$

Gage Gage Rec DI

Number Type

$\begin{array}{cccccccc}(\mathrm{m}) & (\mathrm{m}) & (\mathrm{m}) & (\mathrm{m}) \\ \text { C_642-1 STR } & \text { P REM H } & -4.32 & -4.32 & -15.38 & 0.26\end{array}$

$\begin{array}{llll}-4.32 & -4.32 & -15.38 & -0.75\end{array}$

$\begin{array}{lllll}\text { Gage Coordlnates } & & & \\ \text { Prin Stat } & \text { Room } & \text { Gage } & \text { Inst } & \text { Po } \\ \text { Z1 } 22 & 21 & \text { Manuf } & \text { Date } & \text { Item }\end{array}$

Comments

$\begin{array}{lllll}1.30 & 1.22 & 1.47 & 1.39 & 09 / 26 / 90 \\ 1.30 & 1.23 & 1.47 & 1.40 & 09 / 26 / 90\end{array}$

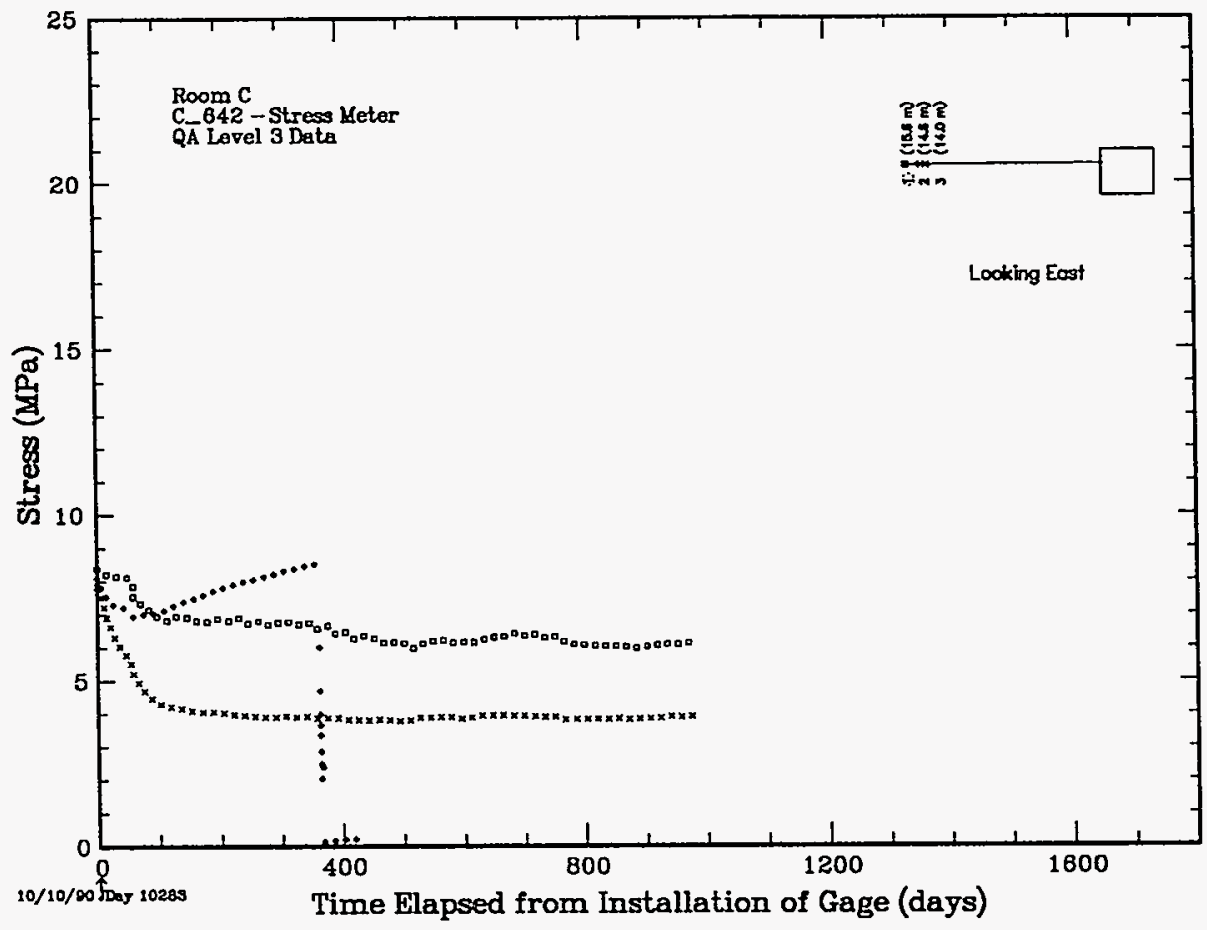

Figure 2.2.2v. Stress Meter BuMines Unit C_642 
Table 2.2.2w. Stress Meter BuMines Unit C_643

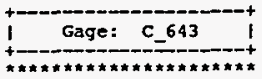

\begin{abstract}
n*2** C_643 PI Coments *****
09/03/93 TLC: GTB [RANK $=10(1), 10(2), 10(3)$ ] DATA OF THIS UMIT ARE OUTSTANDING.

THIS BUMINES STRESS GAGE WAS INSTALLED 60 DAYS BEFORE IHE START OF MINING OF

THE INTERMEDIATE SCALE BOREHOLE. VERY LITILE REDUCTION WAS REQUIRED EXCERT FOR

MINOR DRLESION OF SCATIRR. THE RESULTS OE THE MINING CAN BE SEEN START

[COMPRESS ION $2.15: 1$ ) (DRM)
\end{abstract}

***** C_643 Location *****

Principal station
Station

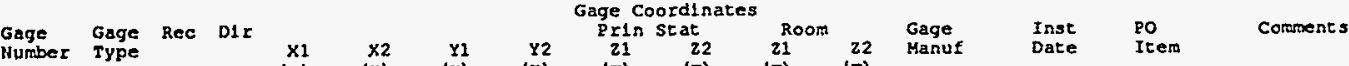

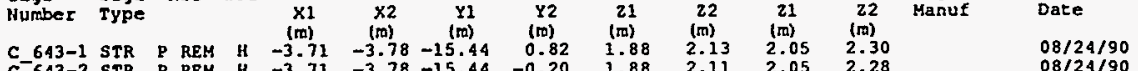

$\begin{array}{llllllllllll}\text { C_643-1 STR } & \text { P REM } & \text { R } & -3.71 & -3.78 & -15.44 & 0.82 & 1.88 & 2.13 & 2.05 & 2.30 & 0 \\ \text { C-643-2 STR } & \text { P REM } & H & -3.71 & -3.78 & -15.44 & -0.20 & 1.88 & 2.11 & 2.05 & 2.28 & 08 / 24 / 90 \\ C_{-}^{-643-3} \text { STR } & \text { P REM } & H & -3.71 & -3.77 & -15.44 & -0.81 & 1.88 & 2.10 & 2.05 & 2.27 & 08 / 24 / 90\end{array}$

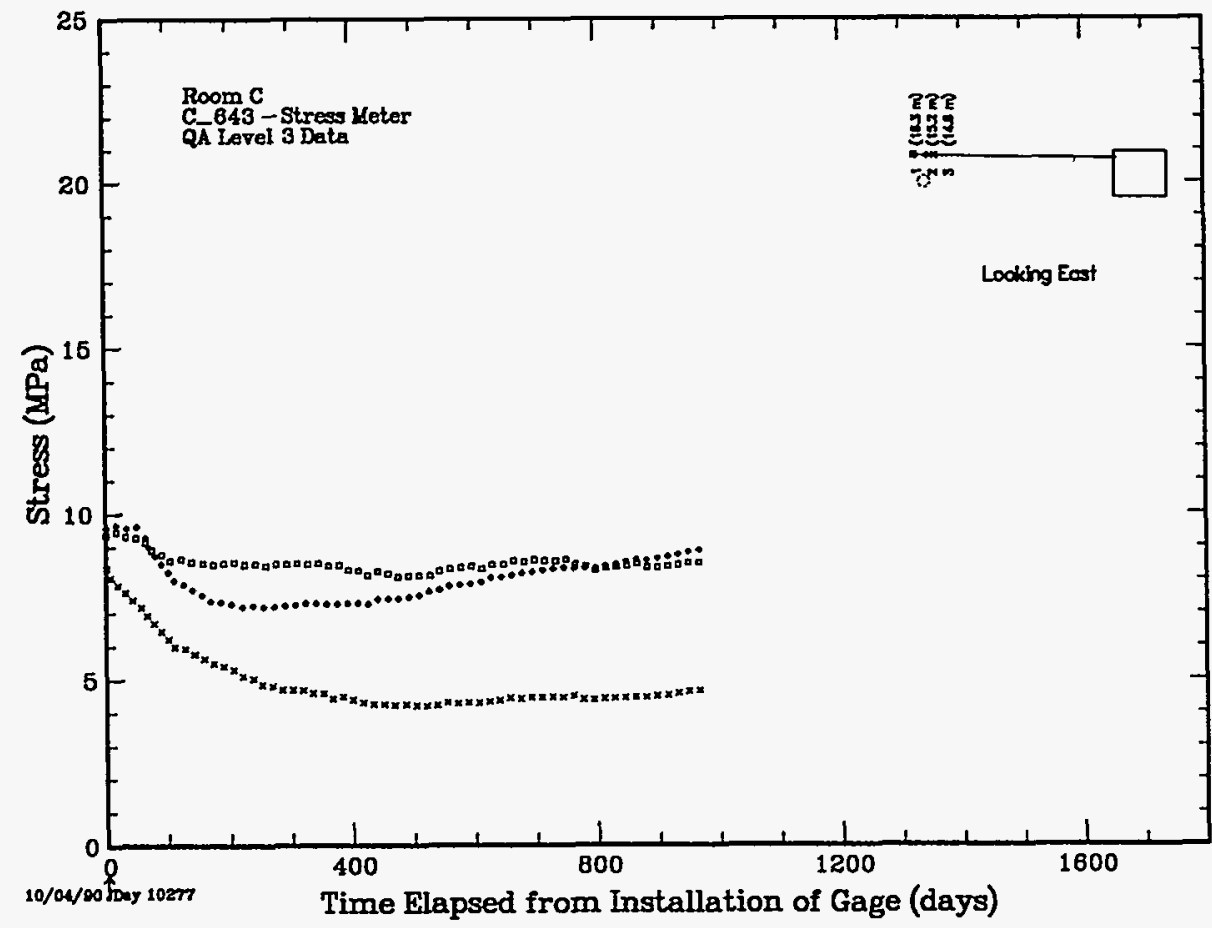

Figure 2.2.2w. Stress Meter BuMines Unit C_643 
Table 2.2.2x. Stress Meter BuMines Unit C_644

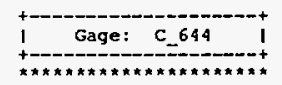
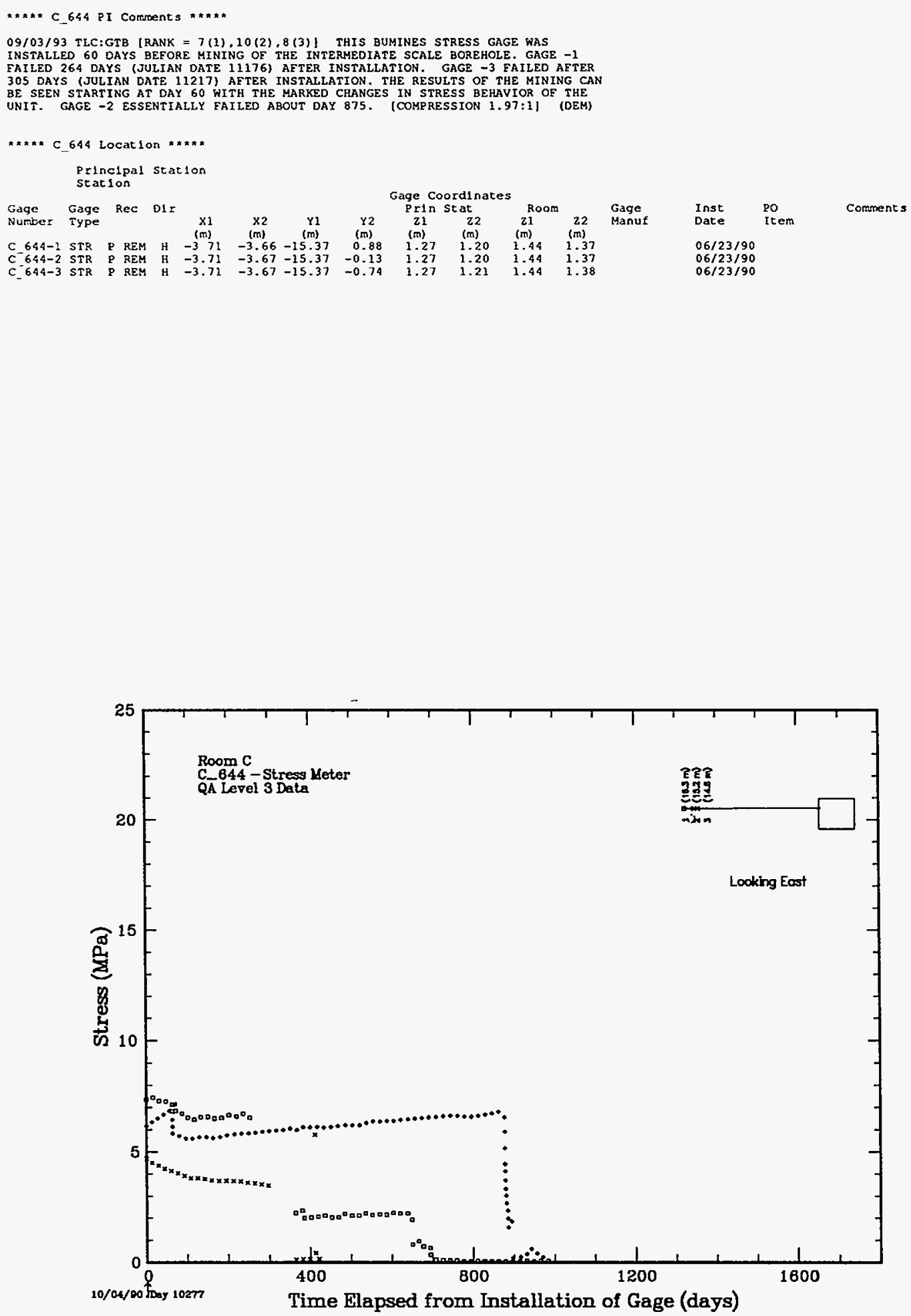

Figure 2.2.2x. Stress Meter BuMines Unit C_644 
Table 2.2.2y. Stress Meter BuMines Unit C_645

\begin{tabular}{|c|c|c|}
\hline 1 & Gage: & C 645 \\
\hline
\end{tabular}

W..** C_645 PI Comments *\#**

$09 / 03 / 93$ TLC; GTE [RANK $=3(1), 3(2), 10(3)$ ] THIS BUMINES STRESS GAGE WAS INSTALLED 54 DAYS BEFORE MINING OF THE INTERMEDIATE SCALE BOREHOLE. THE CAUSE OF THE DISTURBANCE RESULTING IN THE FAILURE OF GAGE -1 AND -2, AND THE SUDDEN RISE IN THE DATA OF GAGE $\rightarrow 3$ SOME 24 DAYS (JULIAN DATE 10307) AFTER INSTALLATION IS UNKNONN. THE RESULTS OF THE HINING CAN BE SEEN STARTING AT DAY 54 WITH IHE MARKED CHANGES IN THE STRESS BEHAVIOR OE THE UNIT. DURING IHE MINING. THE

PRESSURE LINES OF GAGES -1 AND -2
GAGES. ICOMPRESSION $2.98: 1]$ (DEM)

*x*n* C 645 Locat Ion *kx**

Principal station

Station

Gage Gage Rec o1

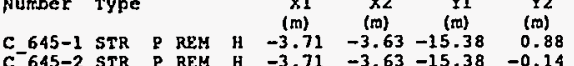

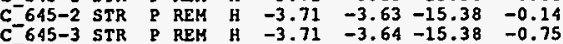

Gage Coordinates
Prin Stat
Z1

Inst Po

Comments

$10 / 01 / 90$

$10101 / 90$

$10 / 01 / 90$

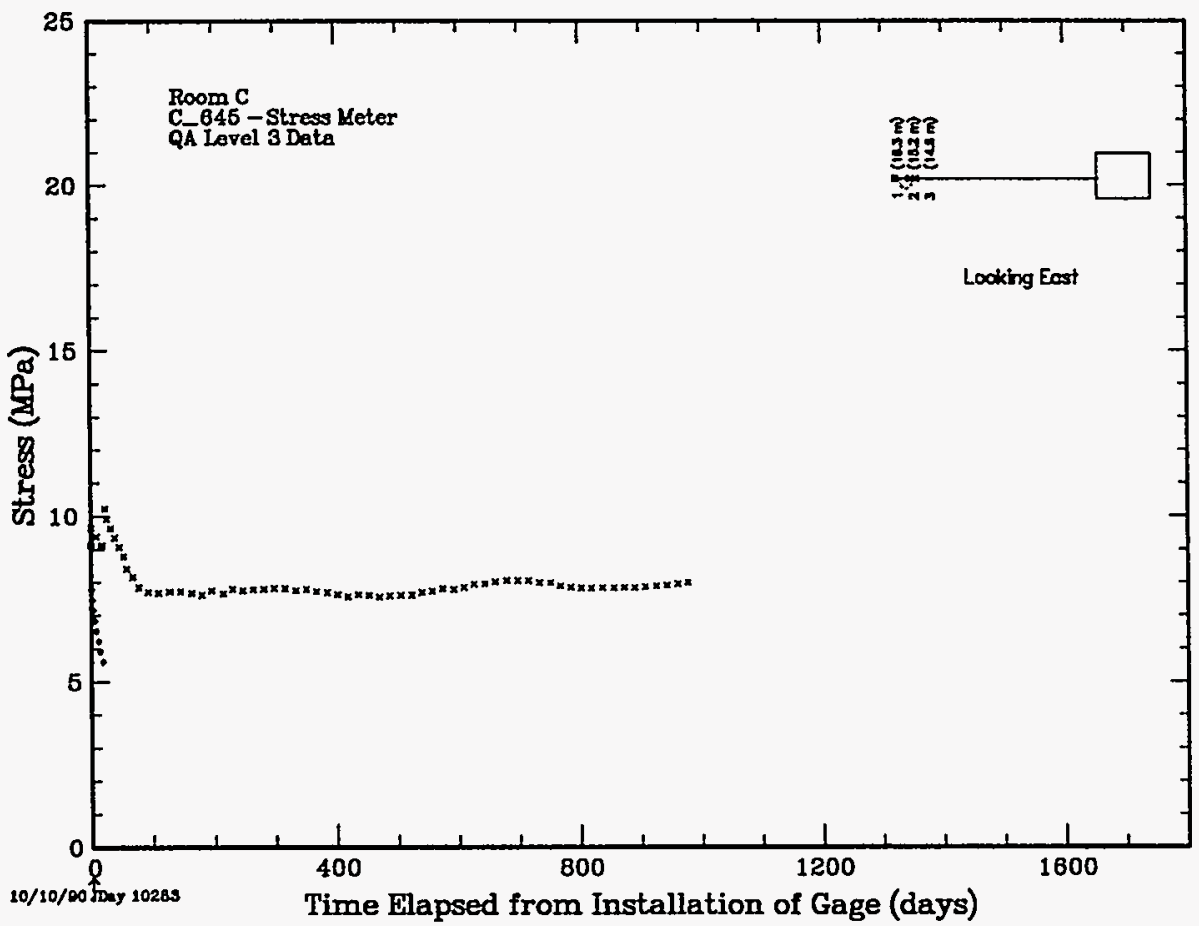

Figure 2.2.2y. Stress Meter BuMines Unit C_645 
Table 2.2.2z. Stress Meter BuMines Unit C_646

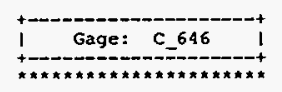

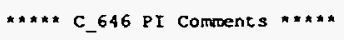

09/03/93 TLC:GTB [RANK = $10(1), 10(2)$ ) THIS BUMINES STRESS GAGE WAS INSTALLED 54 DAYS BEFORE MINING OF THE INTERMEDIATE SCALE BOREHOLE. FOR THIS UNIT, GAGE LITTLE REDUCTION KAS REOUIRED EXCEPT FOR MINOR DELETION OF SCATTER. RESULTS OF THE MINING CAN BE SEEN STARTING AT DAY SA MITH MARKED CHANGES IN THE STRESS

BEHAVIOR OF THE UNIT. (COMPRESSION 1.67:1] (DEM)

***** C_646 Location ***** Principal station station

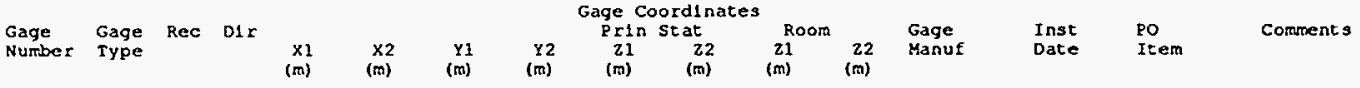

$\begin{array}{llllllllllllll}\text { C } 646-2 & \text { STR } & \text { P REM } & \text { H } & -3.71 & -3.75 & -15.37 & -0.89 & 0.00 & 0.00 & 0.17 & 0.17 & 10 / 08 / 90 \\ \text { C } 646-3 & \text { STR } & \text { P REM } & \text { H } & -3.71 & -3.71 & -15.37 & -2.87 & 0.00 & 0.00 & 0.17 & 0.17 & 10 / 08 / 90\end{array}$

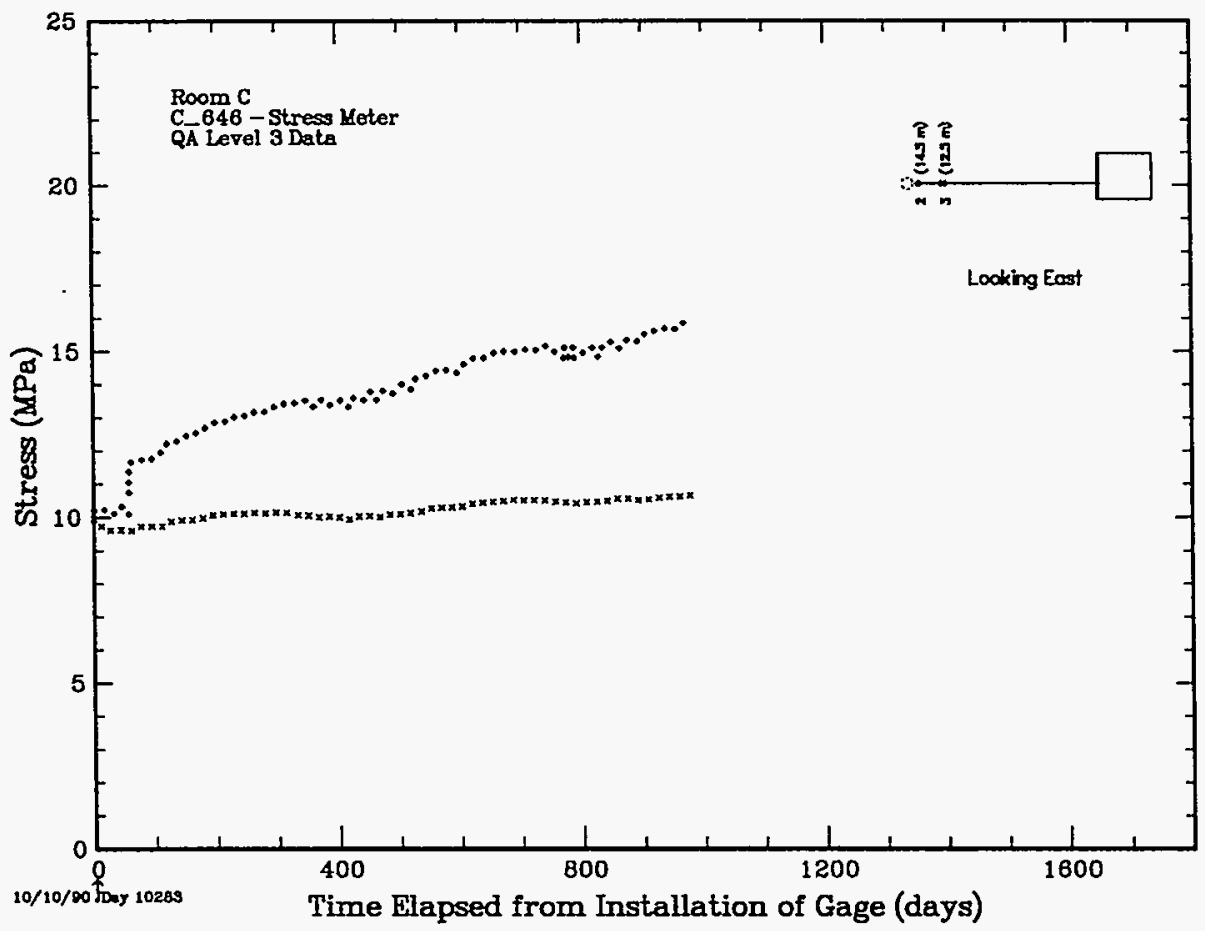

Figure 2.2.2z. Stress Meter BuMines Unit C_646 
Table 2.2.2aa. Stress Meter BuMines Unit C_651

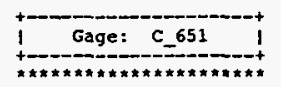

*A*k* C_651 PI comstrents *****

09/03/93 TLC:GTB [RANK $=10(1), 10(2), 10(3)$ ) DATA OF THIS UNTT ARE OUTSTANDING.

THIS BUMINES STRESS GAGE WAS INSTALLED 54 DAYS BEFORE THE START OF MINING OF

FOR MINOR OELETION OF SCATTER. THE RESULTS OF THE MINING CAN BE SEEN STARTING

AT DAY 54 WITH MARKED CHAKGES IN THE STRESS BEHAVIOR OF THE UNIT.

[COMPRESSION 2,49:1] (DEM)

\#**** C_651 Locarion $* * * * *$

$$
\begin{aligned}
& \text { Principss station } \\
& \text { Station }
\end{aligned}
$$

Gage ReC Dir Gage Coordinates

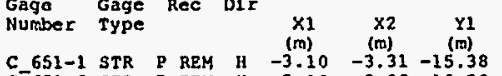

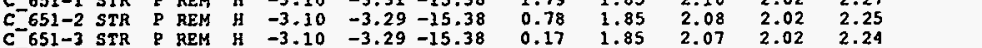

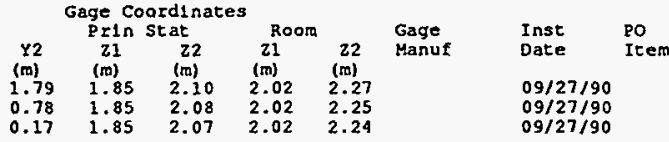

Comsents

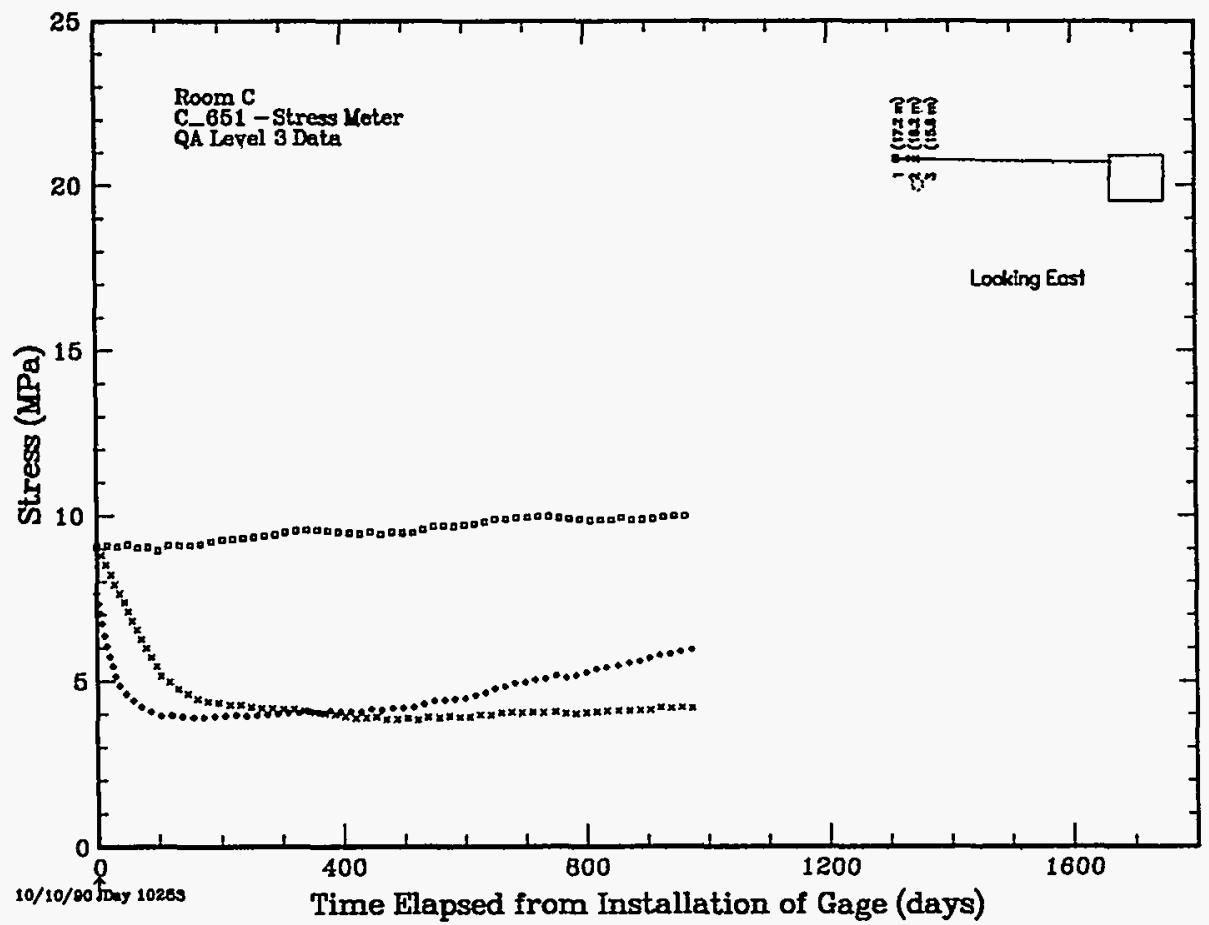

Figure 2.2.2aa. Stress Meter BuMines Unit C_651 
Table 2.2.2bb. Stress Meter BuMines Unit C_652

\begin{tabular}{|c|c|}
\hline I & Gage: C 652 \\
\hline
\end{tabular}
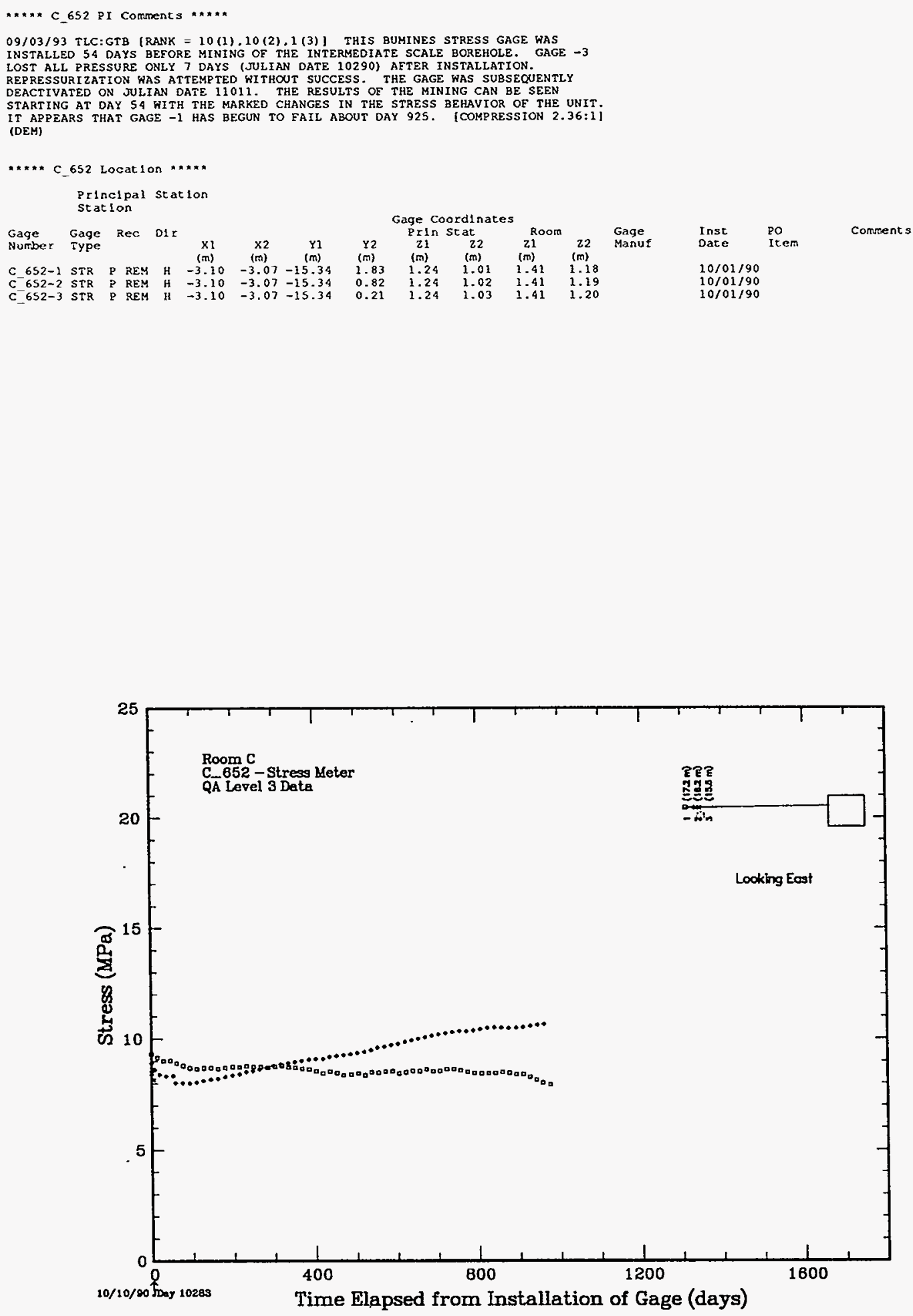

Figure 2.2.2bb. Stress Meter BuMines Unit C_652 
Table 2.2.2cc. Stress Meter BuMines Unit C_653

tor

A**** C_653 PI Corarents $* * \pi * *$

$06 / 03 / 92$ TLC [RANK $=10(1), 10(2), 10(3)$ ] THIS BUMINES STRESS GAGE WAS INSTALLED SCALE BOREHOLE. DURING THE MINING, THE UNIT TRANSDUCER WIRES WERE CUT (JULIAN DATE 10341)
DEACTIVATION OF THE UNIT. [COMPRESSION 1.43:1] (DEM)

**** C_653 Location $* \star * \star *$ principal station

Gage Gage ReC DIr Gage Coordinates

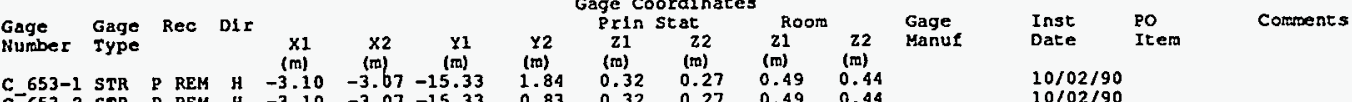

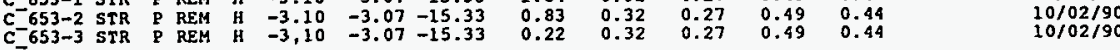

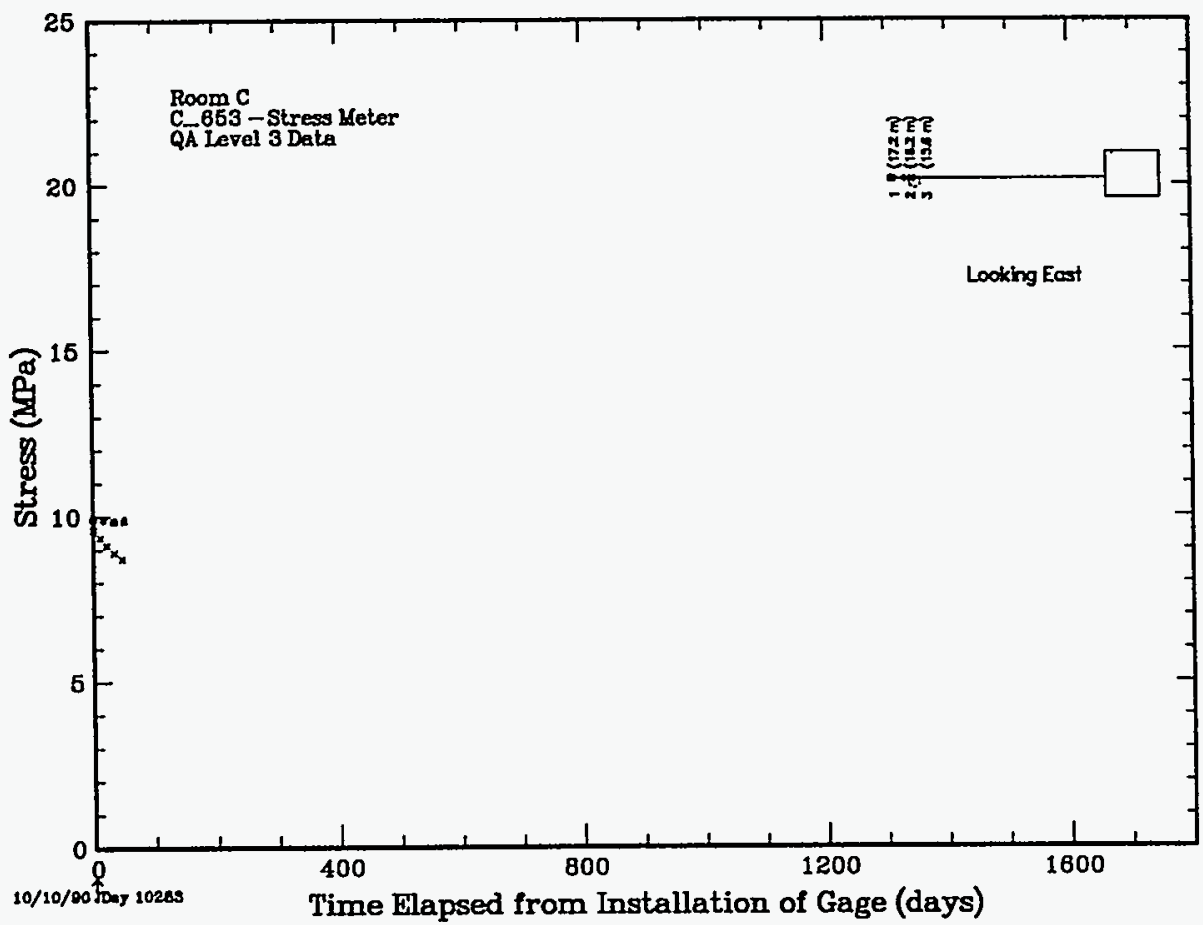

Figure 2.2.2cc. Stress Meter BuMines Unit C_653 
Table 2.2.2dd. Stress Meter BuMines Unit C_654

Gage: C C 654
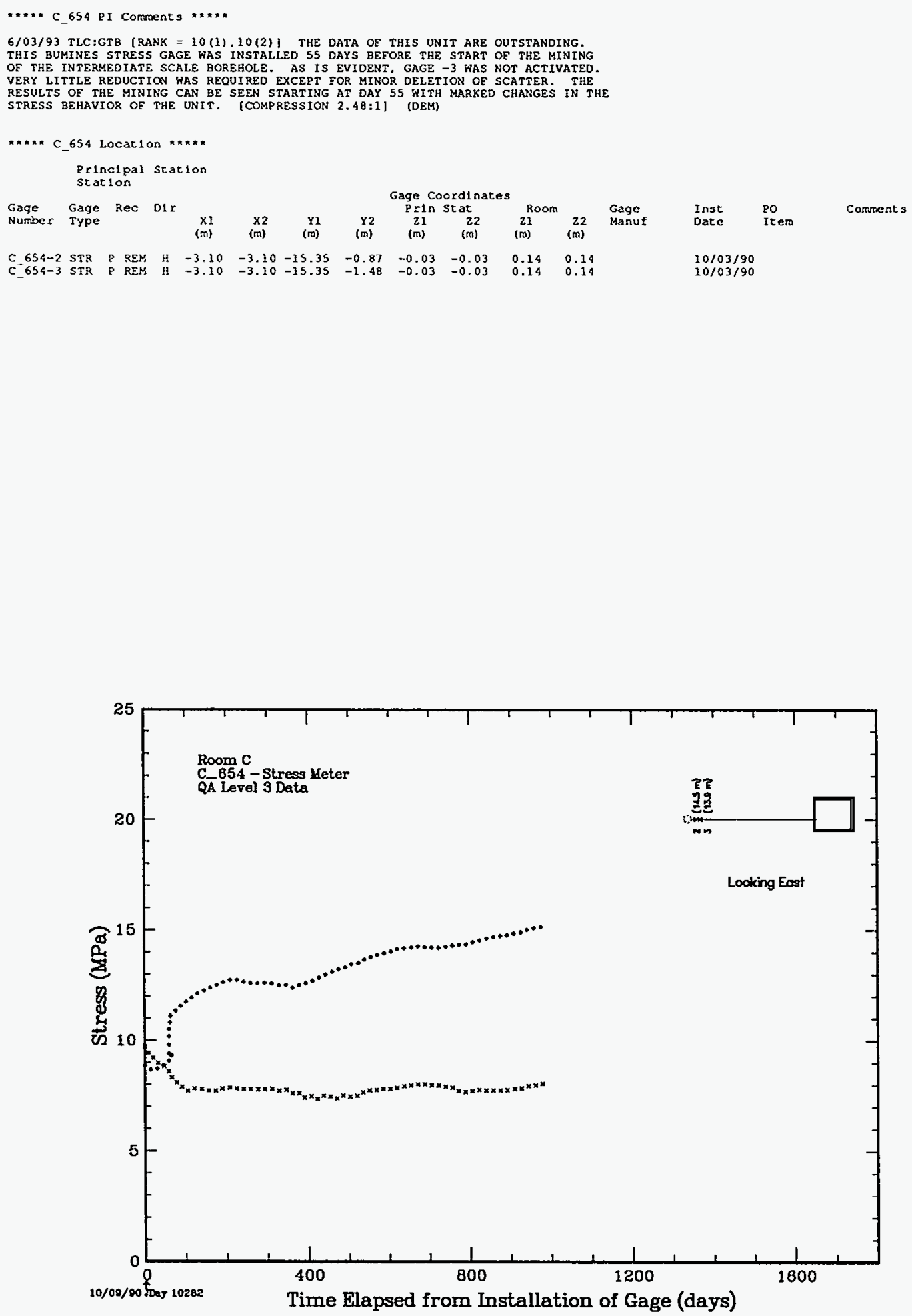

Figure 2.2.2dd. Stress Meter BuMines Unit C_654 
Table 2.2.2ee. Stress Meter SGS Unit C1561

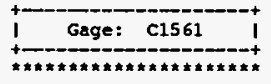

***** C1561 PI Comsents **k**

09/03/93 TLC:GTB [RANK = 10 (1), 10(2)] THE DATA FROM THIS UNIT ARE OUTSTANDING. THIS SGS STRRSS GAGE WAS INSTALLED 193 DAYS BEFORE MINING OF THE INTERHEDIATE SCALE BOREHOLE. VBRY LITTLE REDUCTION WAS NECESSARY EXCEPT FOR MINOR DELETION OF SCATTER. THE RESULTS OF THE HINING CAN BE SEEN STARTING AT DAY 193 HITH THE
RISE IN STRESS SHOWN BY THE UNIT. IHE CAUSE IN THE RISE IN STRESS OF GAGE -1 AT APPROX IMATELY 470 DAYS IS UNKNONN. [COMPRESSION 3.52:1) (DEM)

****** C1561 Location *****

Princigal station

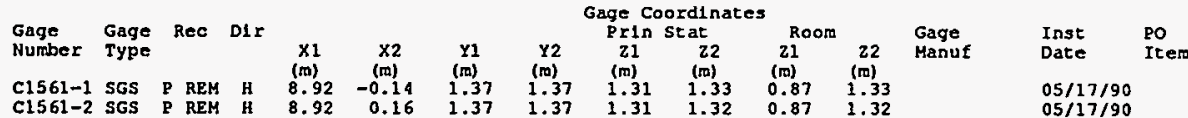

Combents

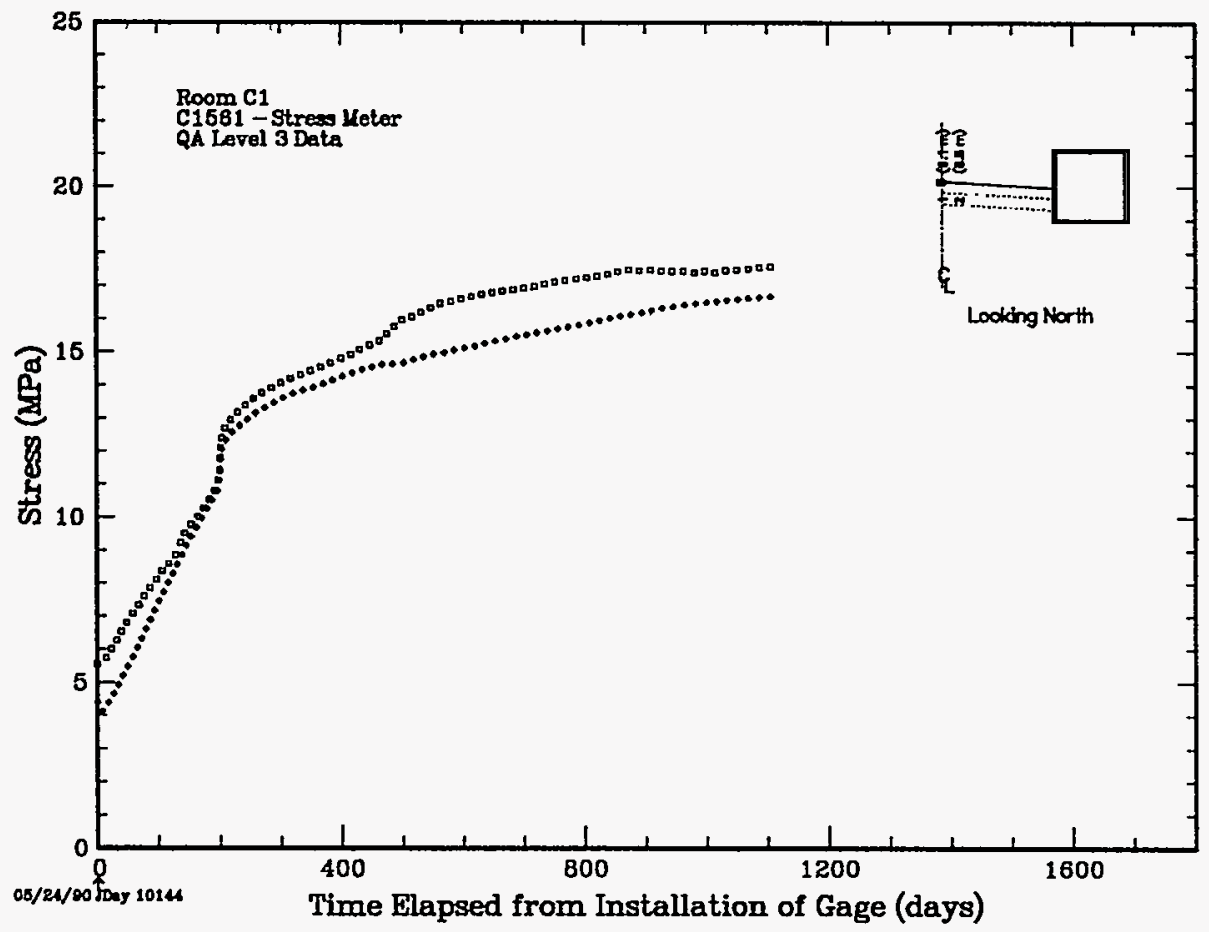

Figure 2.2.2ee. Stress Meter SGS Unit C1561 
Table 2.2.2ff. Stress Meter SGS Unit C1562

Gage: $\quad$ c1562

Ax:** C1562 PI Coments anx**

09/03/93 TLC:GTB [RANK = $10(1), 10(2)$ ] THE DATA FROM THIS UNIT ARE OUTSTANDING. THIS SGS STRESS GAGE WAS INSTALLED 59 DAYS BEFORE MINING OF THE INTERMEDIATE SCALE BOREHOLE. VERY LITTLE REDUCTION WAS NECESSARY EXCERT THE THTER DELETEON OF SCATTER. THE RESULTS OF THE MINING CAN BE SEEN STARTING AT DAY SS
CHANGE IN STRESS AS SHOWN BY THE UNIT. [COMPRESSION $3.83: 1$ ] (DEM)

***** C1562 Location $* * * * *$

Principal station
Station

Gage coordinates

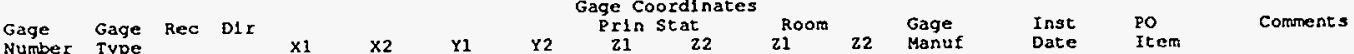

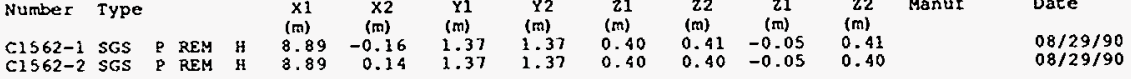

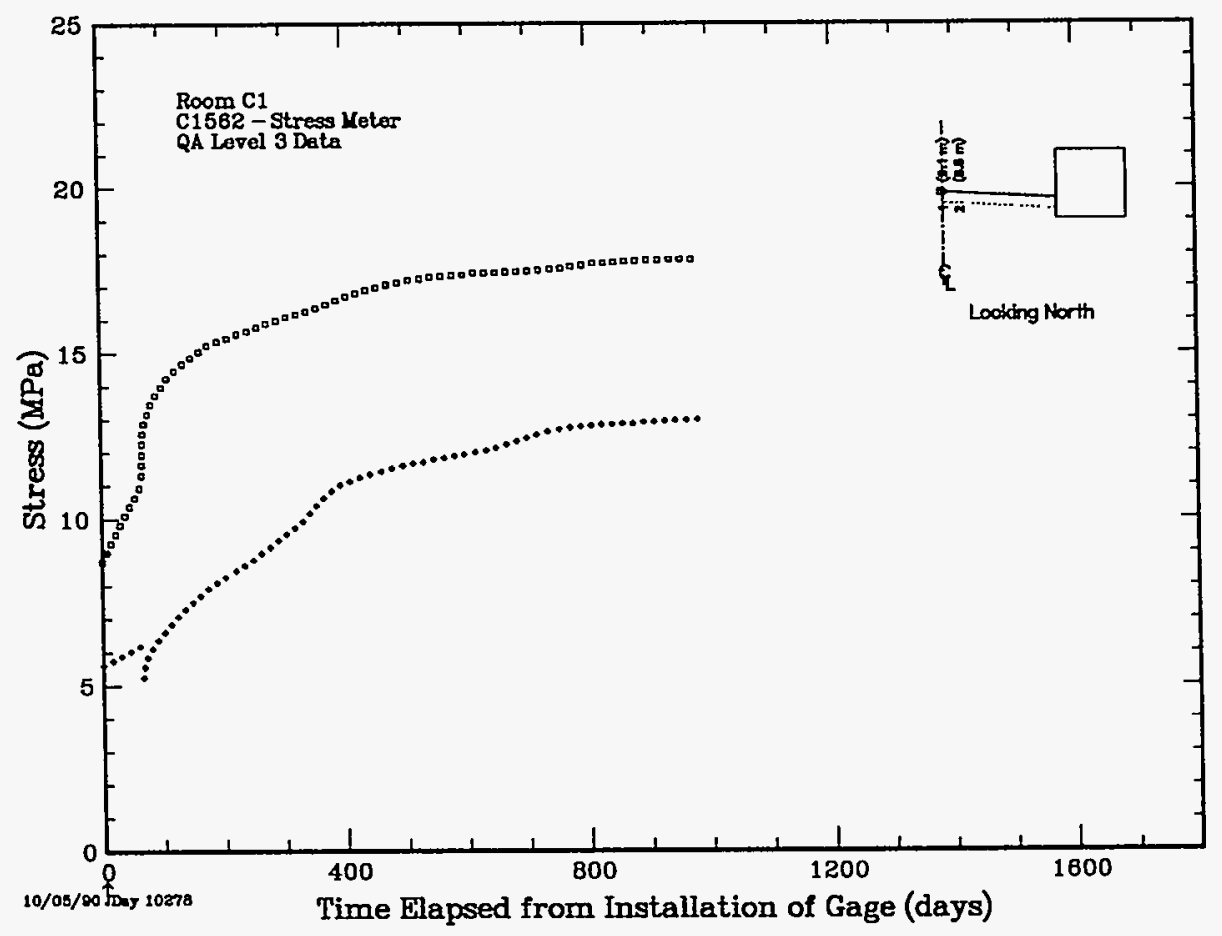

Figure 2.2.2ff. Stress Meter SGS Unit C1562 
Table 2.2.2gg. Stress Meter SGS Unit C1563

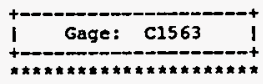

*\#*** C1563 PI Comrents ******

09/03/93 TLC: GTB [RANK = $10(1), 8(2)$ ] THIS SGS STRESS UNIT WAS INSTALLED 193 OAYS BEFORE MINING OF THE INTERMEOIATE SCALE BOREHOLE. GAGE -2 FAILED 448 DAYS (JULIAN DATE 11166) AETER INIETALAT IMCEE ATE

***** C1563 Location *****

\section{Principal station
Station}

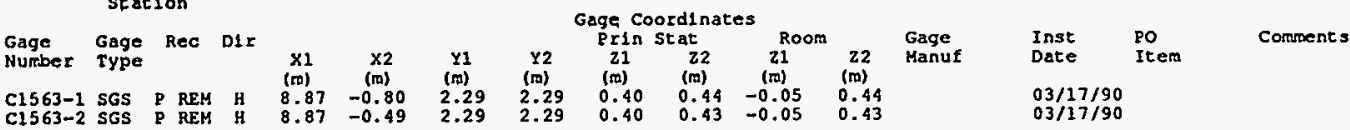

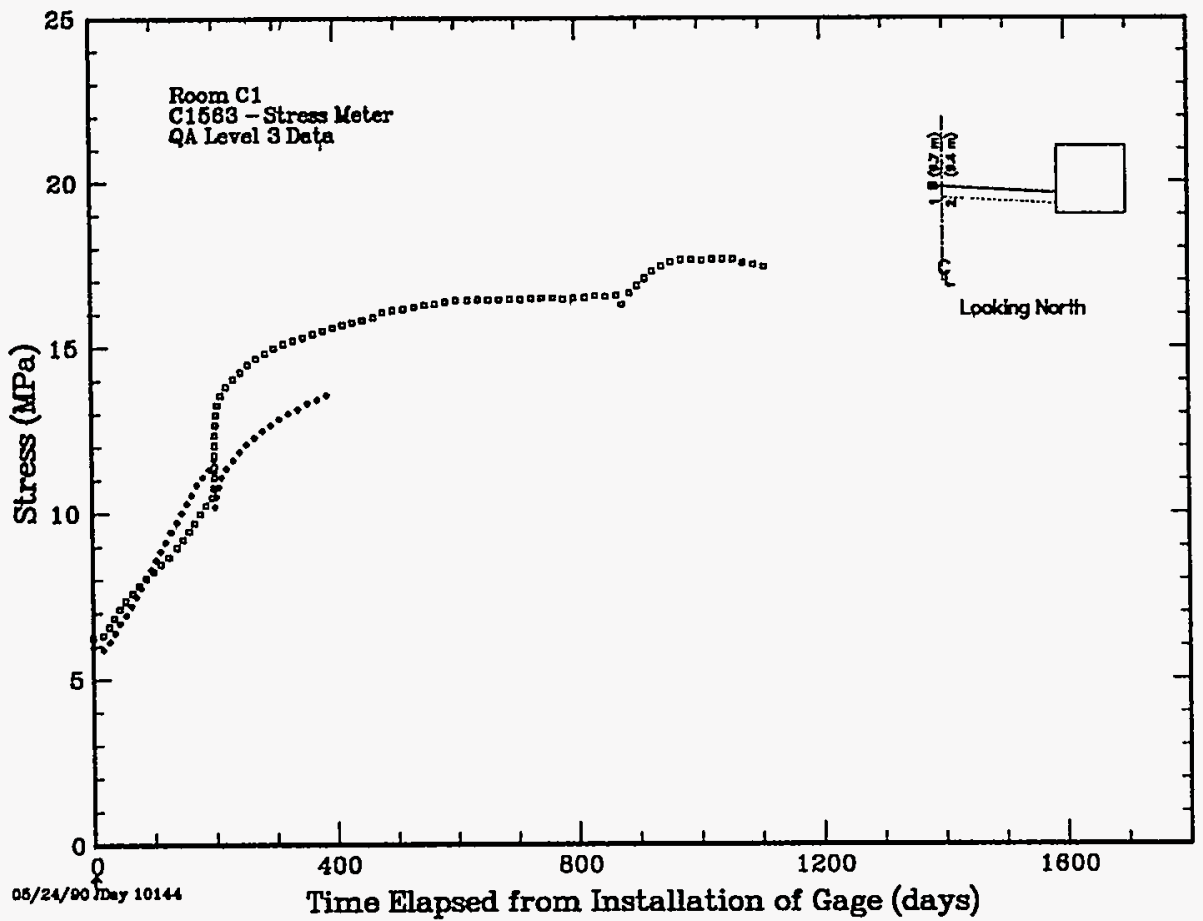

Figure 2.2.2gg. Stress Meter SGS Unit C1563 
Table 2.2.2hh. Stress Meter SGS Unit C157I

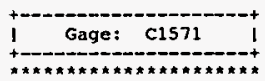

***** C1571 PI Comments *****

09/03/93 TLC:GTB [RANK $=10(1), 10(2)$ ] THE DATA FROM THIS UNIT ARE OUTSTANDING.

THIS SGS STRESS UNIT WAS INSTALLED 193 DAYS BEFORE MINING OE THE INTERMEDIATE

SCALE BCREHOLE. VERY LIITLE, REDUCITON WAS REQUIRED EXCEPT FOR MINOR DELETION

OF SCATTER. THE RESULTS OF THE HINING CAN BE SEEN STARTING AT DAY 193 WITH THE

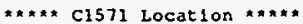

Princlpal station
Station

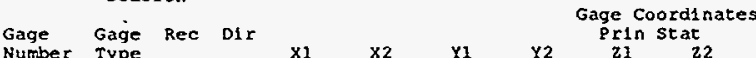

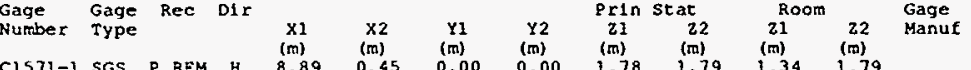

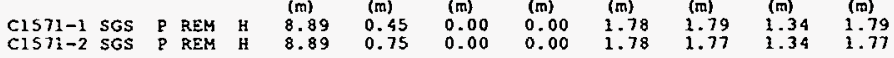

Date $\stackrel{\text { Po }}{\text { Item }}$

Comments

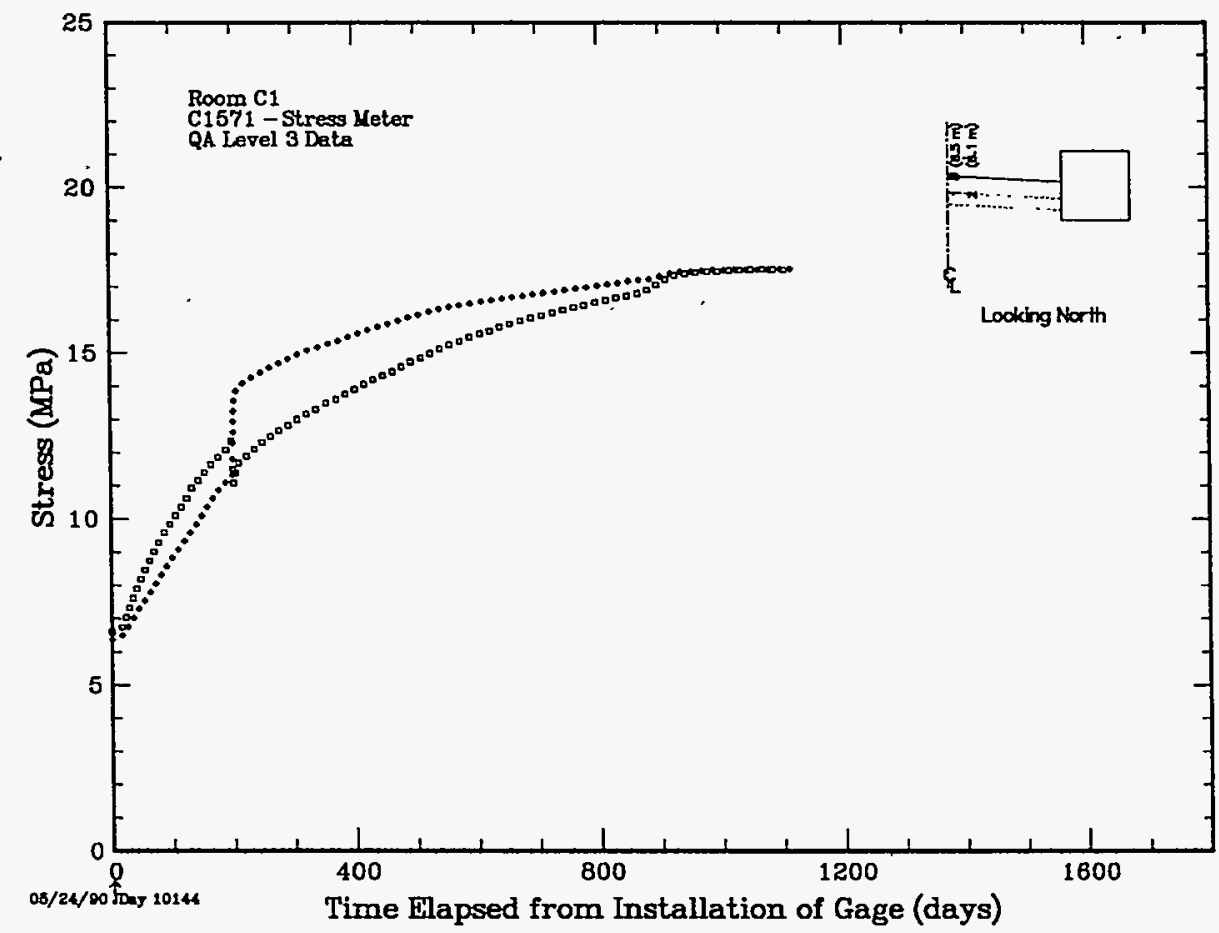

Figure 2.2.2hh. Stress Meter SGS Unit C1571 
Table 2.2.2ii. Stress Meter SGS Unit C1572

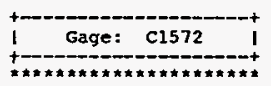

\begin{abstract}
***** C1572 PI Comrents $* \star \star \star * *$
09/03/93 TLC:GTB IRANK = $10(1), 10(2)$ I THE DATA FROM THIS UNIT ARE OUTSTANDING. THIS SGS STRESS UNIT WAS INSTALLED 193 DAYS BEFORE MINIMG OF THE INTERMEDIATE SCALE BOREHOLE. VRRY LITTLE REDUCFION WAS REOUIRED EXCEPT FOR MINOR DELETION CHANGE IN STRESS AS SHOKN BY THE UNTT CANE DAY 800 IS PROBABLY NOT REAL. BUT EVENTUALIY RESULTS IN FAILURE AT DAY 1060.

[COMPRESSION $2.33: 1$ ] (DEM)
\end{abstract}

**** C1572 Location *****

Princlpal station
station

Gage Gage Rec Dir Gage Coordinates

C1572-1 SGS P REM H (m)

$\begin{array}{llllll}\text { C1572-1 } & \text { SGS } & \text { P } & \text { REM } & H & 8.91 \\ \text { C1572-2 SGS } & \text { P } & \text { REM } & H & 8.91\end{array}$

\begin{tabular}{|c|c|c|c|c|c|c|c|c|c|}
\hline \multirow{3}{*}{$\begin{array}{l}x 2 \\
(m) \\
0.47 \\
0.77\end{array}$} & \multicolumn{6}{|c|}{$\begin{array}{l}\text { Gage Coordinates } \\
\text { Prin Stat }\end{array}$} & \multirow[b]{2}{*}{$\begin{array}{l}\text { Gage } \\
\text { Manuf }\end{array}$} & \multirow[b]{2}{*}{$\begin{array}{l}\text { Inst } \\
\text { Date }\end{array}$} & \multirow{3}{*}{$\begin{array}{l}\text { PO } \\
\text { I }\end{array}$} \\
\hline & & & $z_{21}$ & 22 & & & & & \\
\hline & 0.00 & 0 & 0.87 & 0.87 & 0.42 & $\begin{array}{l}(m) \\
0.87\end{array}$ & & $05 / 16 / 90$ & \\
\hline
\end{tabular}

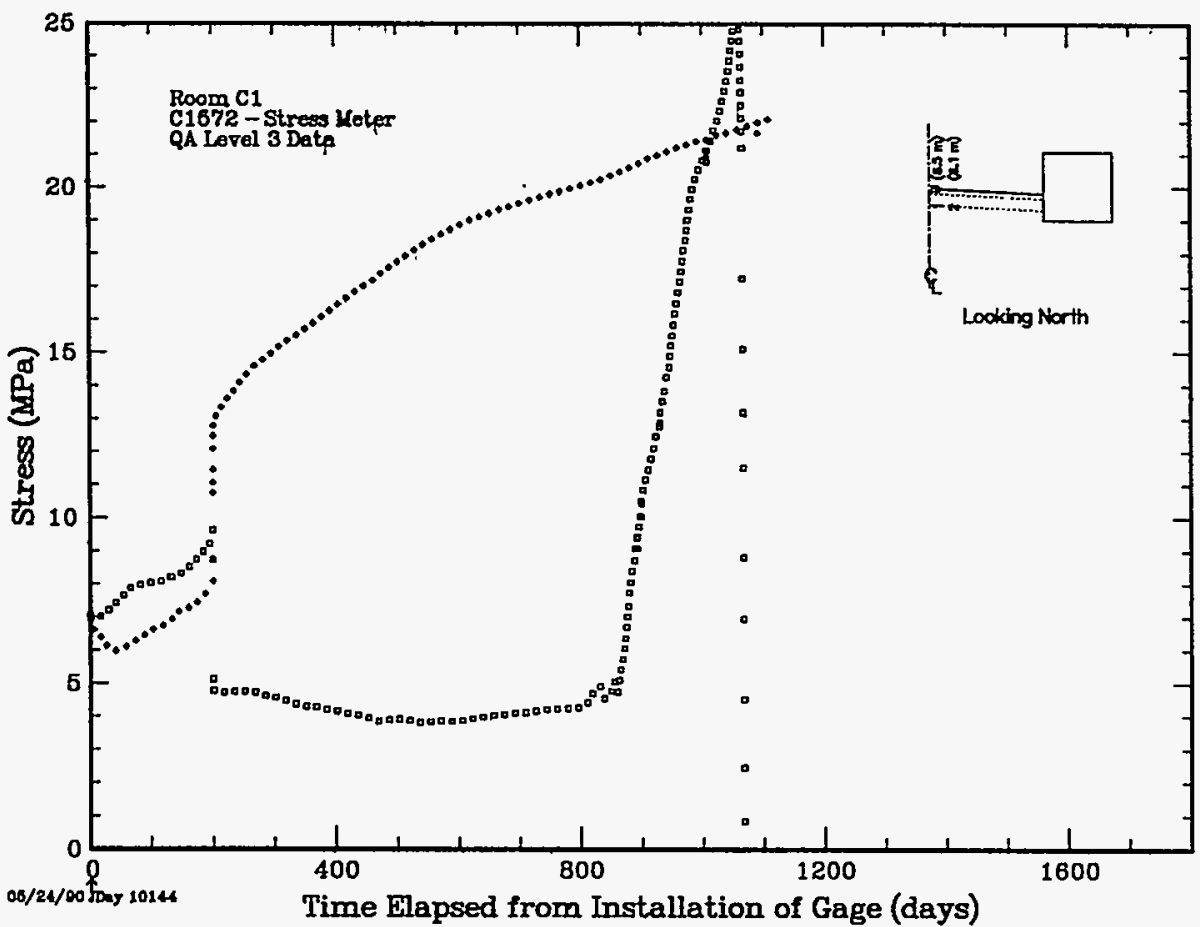

Figure 2.2.2ii. Stress Meter SGS Unit C1572 
Table 2.2.2jj. Stress Meter SGS Unit C2523

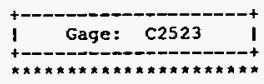

*an* C2523 PI Comments anta*

O9/02/93 TLC:GTB [RANK $=20(1), 10(2)$ ] THE DATA FROM THIS UNIT ARE OUTSTANDING. THIS SGS STRESS METER UNIT WAS INSTALLED 228 DAYS BEFORE MINING OF THE INTERMEDTATE SCALE BOREHOLE. VERY LITTLE REDUCTION WAS PERFORMED EXCEPT FOR MINOR DELETION OE SCATTER. THE RESULTS OF THE MINING CAN BE SEEN STARTING ICOMPRESSION $2.86: 1]$ (OEM)

**** C2523 Location **n**

princlpal station Station

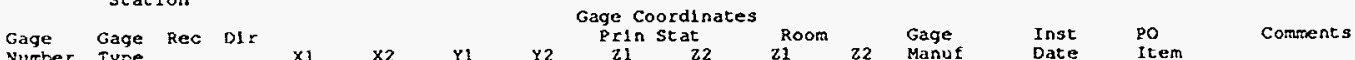

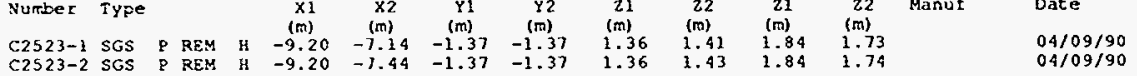

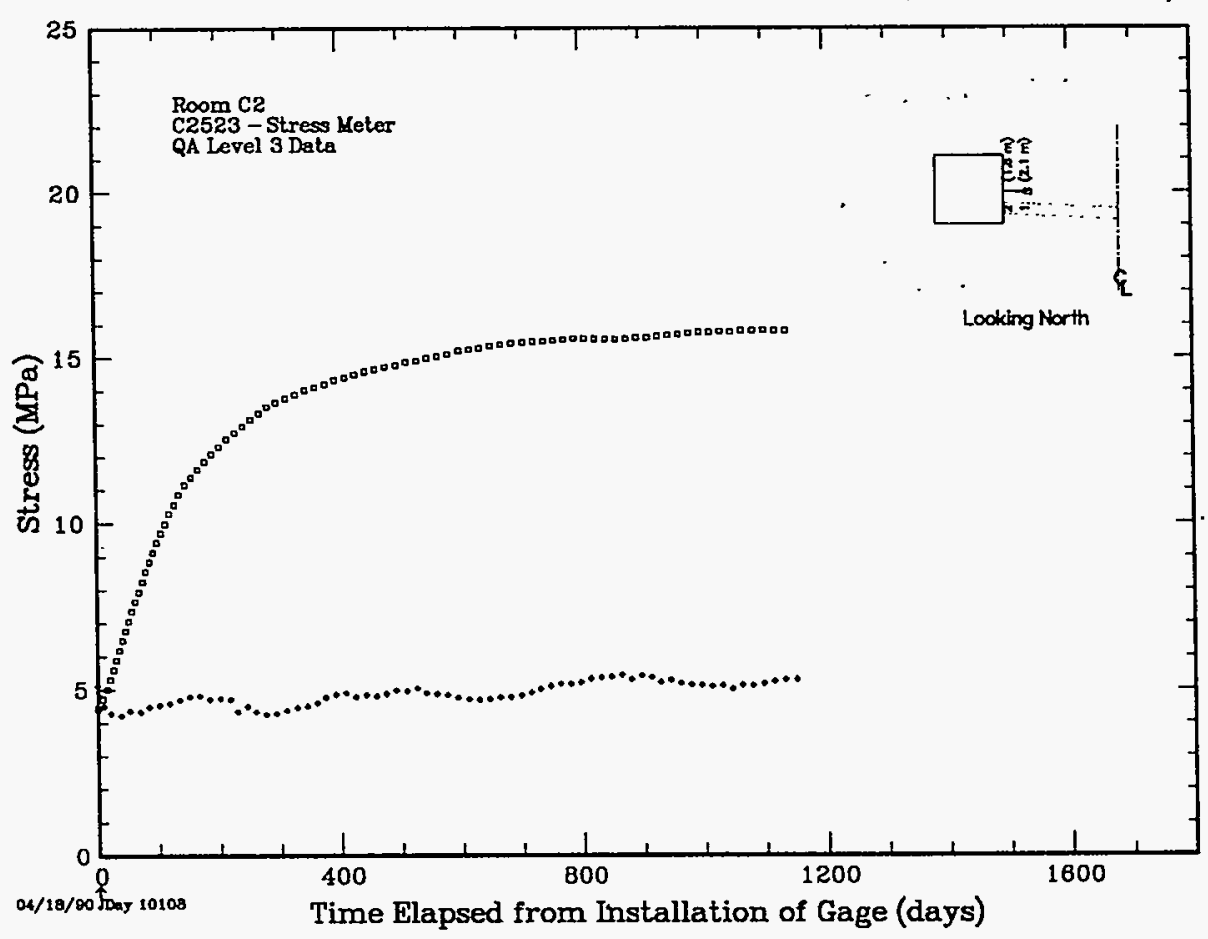

Figure 2.2.2jj. Stress Meter SGS Unit C2523 
Table 2.2.2kk. Stress Meter SGŞ Unit C2524

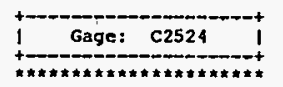

$* * * * *$ C2524 PI Comrents $* * * n *$

09/02/93 TLC: GTB [RANK $=10(1), 10(2)$ ] THE DATA FROM THIS UNIT ARE OUTSTANDING. THIS SGS STRESS UNIT WAS INSTALLED 228 DAYS BEFORE MINING OE THE INTERHEDIATE SCALE BOREHOLE. VERY LITTLE REPUCIION HAS PERFORHED EXCEPT FOR MINOR DELETIO OF SCATTER. THE RESULTS OF THE MINING CAN BE SEEN STARTING AT DAY 228 WITH

**1* C2524 Location *****

\section{Principal Station
Station}

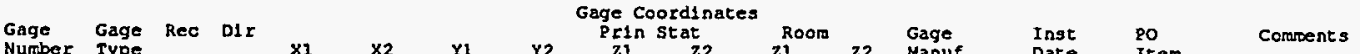

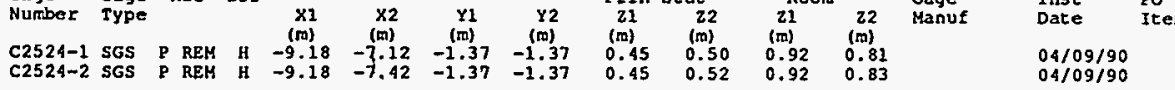

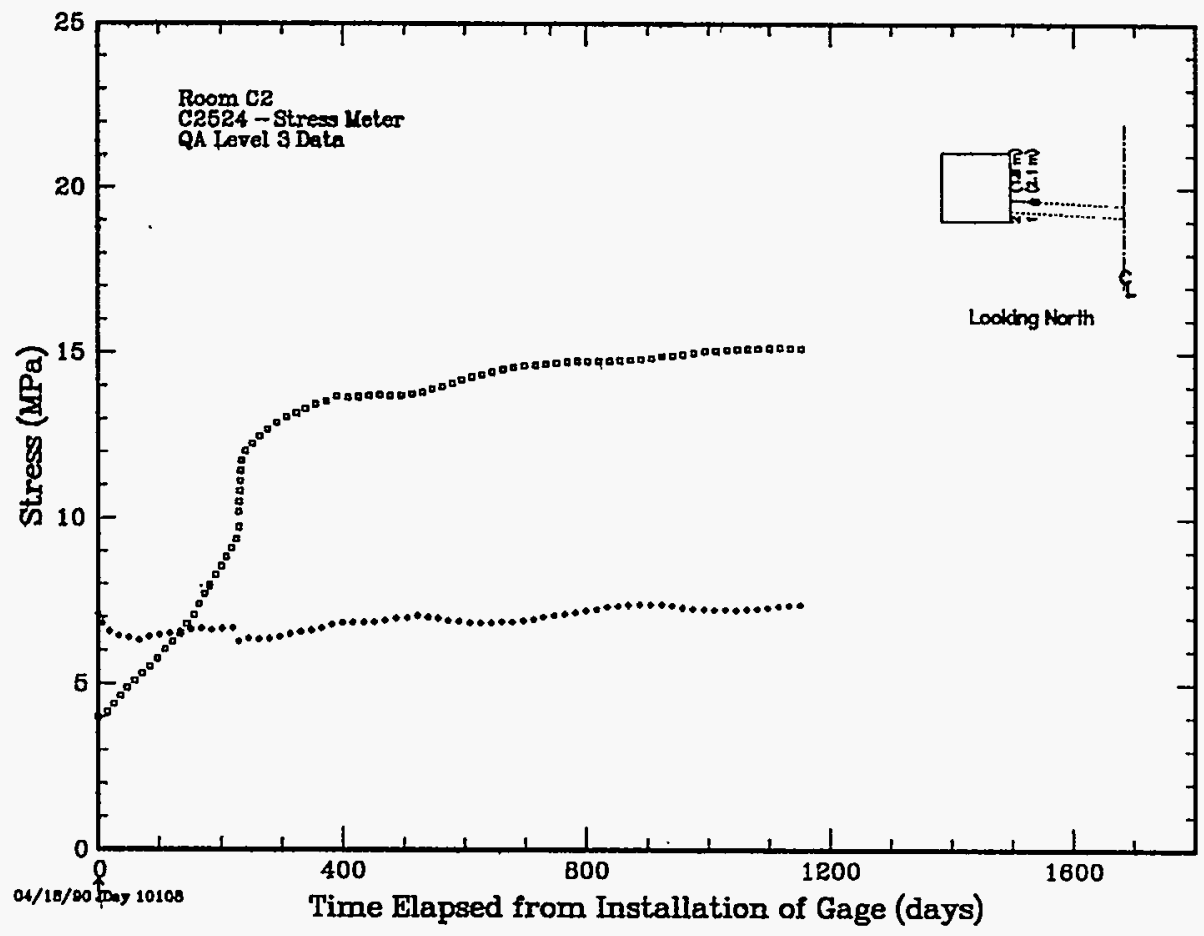

Figure 2.2.2kk. Stress Meter SGS Unit C2524 
Table 2.2.211. Stress Meter SGS Unit C2525

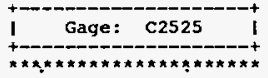

**x** C2525 PI Comments *****

0 $02 / 93$ TLC:GTB [RANK $=10(1), 10(2)]$ THE DATA FROM THIS UNIT ARR OUTSTANDING. THIS SGS STRESS UNIT WAS INSTALLED 228 DAYS BEFORE MINING OF THE INTERMEDIATE SCALE BOREHOLE. VERY LITTLE REDUCTION WAS PERFORMED EXCEPT EOR MINOR DELETION OF SCATTER. THE RESULTS OE THE MINING CAN BE SEEN STARTING AT-DAY. 228 WITH THE QERTUBATION IN KELTS OE THE UIN ANG SAOWN BY THE UNIT AT THIS TIME.

[COMPRESSION $3.68: 1$ ] (DEM)

**x** C2525 Location **x**

Principal station Station

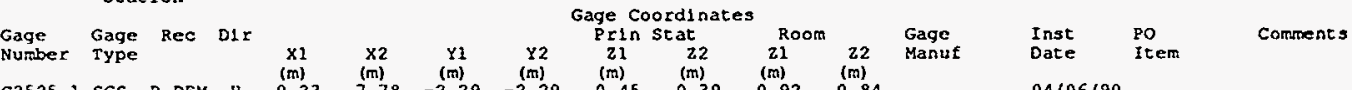

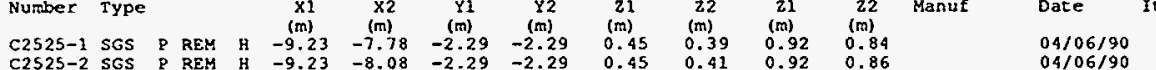

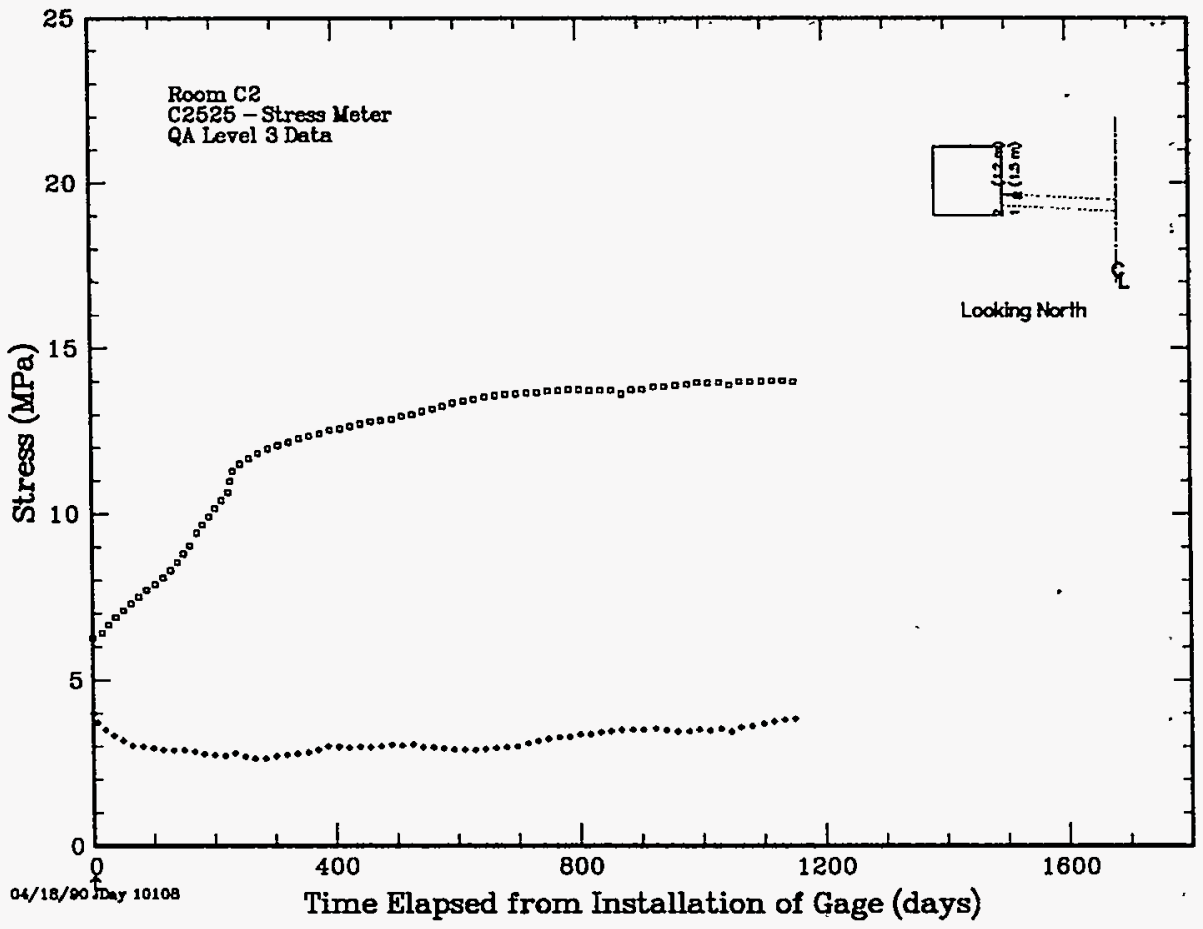

Figure 2.2.211. Stress Meter SGS Unit C2525 
Table 2.2.2mm. Stress Meter SGS Unit C2531

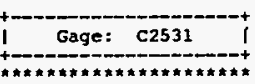

*a*** C2531 PI Comments $* * * * *$

09/02/93 TLC: GTB (RANK $=10(1), 10(2)$ ] IHE DATA FROM THIS UNIT ARE OUTSTANDING. THIS SGS STRESS UNIT WAS INSTALIED 228 DAYS BEEORE MINING OF THE INTERMEDIATE SCALE BOREHOLE. VERY LITTLE REDUCTION KAS PERFORMBD EXCEPT FOR MINOR DRLETION

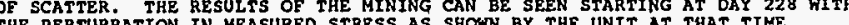
(COMPRESSTON 4 D1:11) (OEM)

***k* C2531 Location *k*** Principal Station
Station

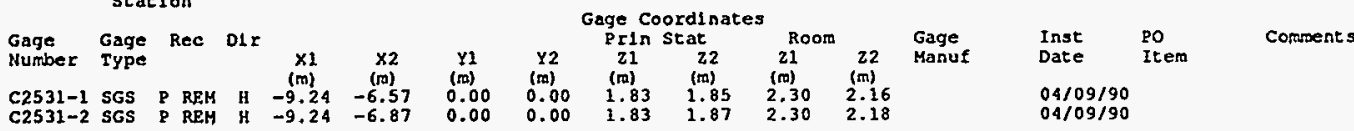

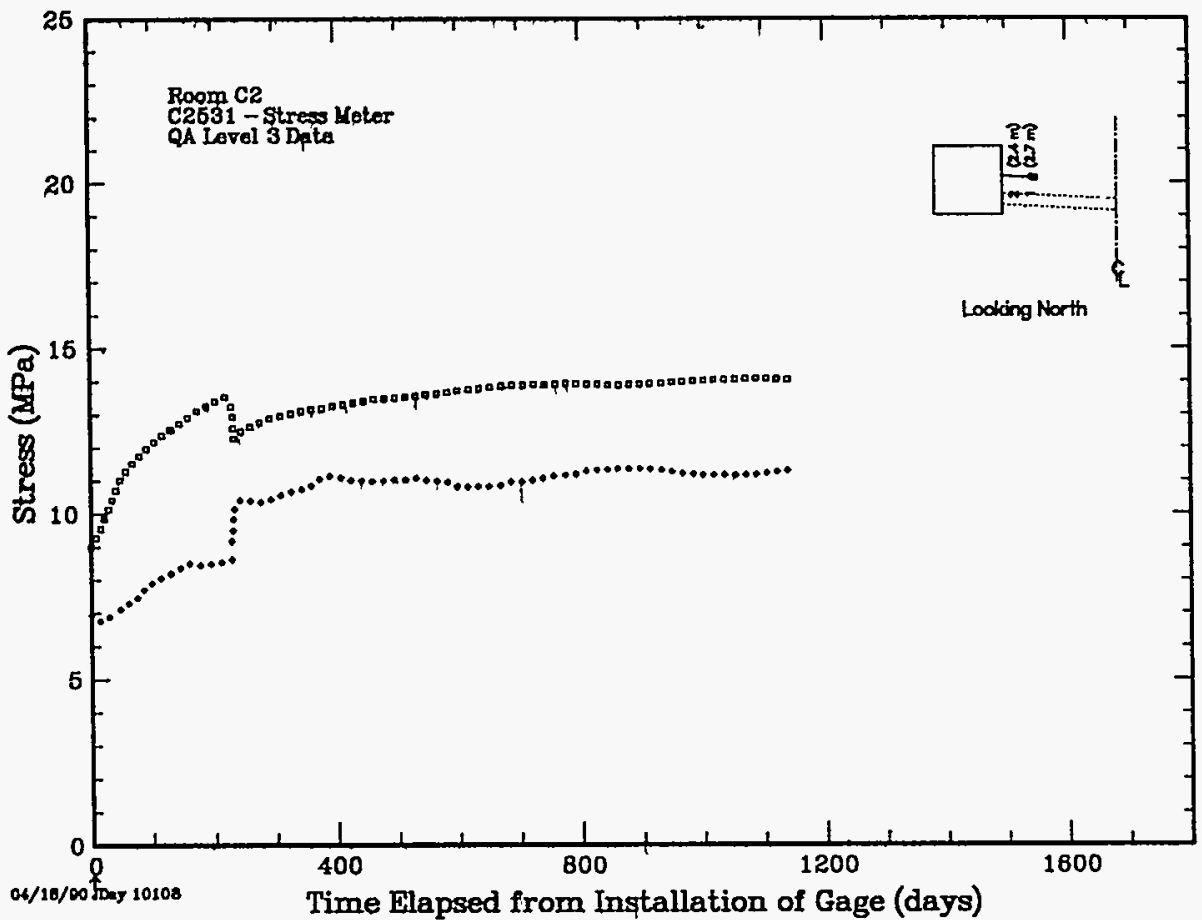

Figure 2.2.2mm. Stress Meter SGS Unit C2531 
Table 2.2.2nn. Stress Meter SGS Unit C2532

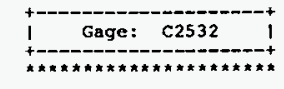

***** C2532 PI Comments $* * * * *$

09/02/93 TLC:GTB [RANK $=10(1)$ 9(2) THIS SGS STRESS UNIT KAS TNSTALIED THE INTERMEOTATE SCALE BOREHOLE GAGE -2 FAILED 416 DAYS (JULIAN DATE 11160 ) AFTER INSTALLATION. LITTLE REDUCTION WAS PERFORMED EXCEPT FOR MINOR DELETION OF SCATTER. THE RESULTS OF THE MINING CAN BE SEEN STARTING AT DAY 228 WITH THE PERTURBATION IN STRESS AS SHOWN BY THE UNIT. THE CAUSE OF THE PERTURBATION IN THE STRESS AT APPROXIMATELY 370 DAYS IS UNKNOAN. [COMPRESSION $1.78: 1$ ) (OEM)

***** C2532 Location ***** Principal station

Gage Gage ReC D1r
Number Type

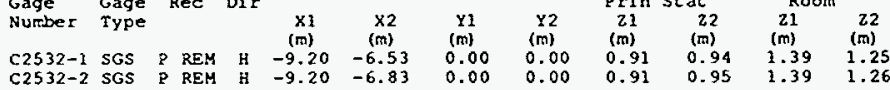

$\begin{array}{lll}\text { Gage } & \text { Inst } & \text { Po } \\ \text { Manuf } & \text { Date } & \text { Item }\end{array}$

Date

$04 / 09 / 90$
$04 / 09 / 90$

Comments

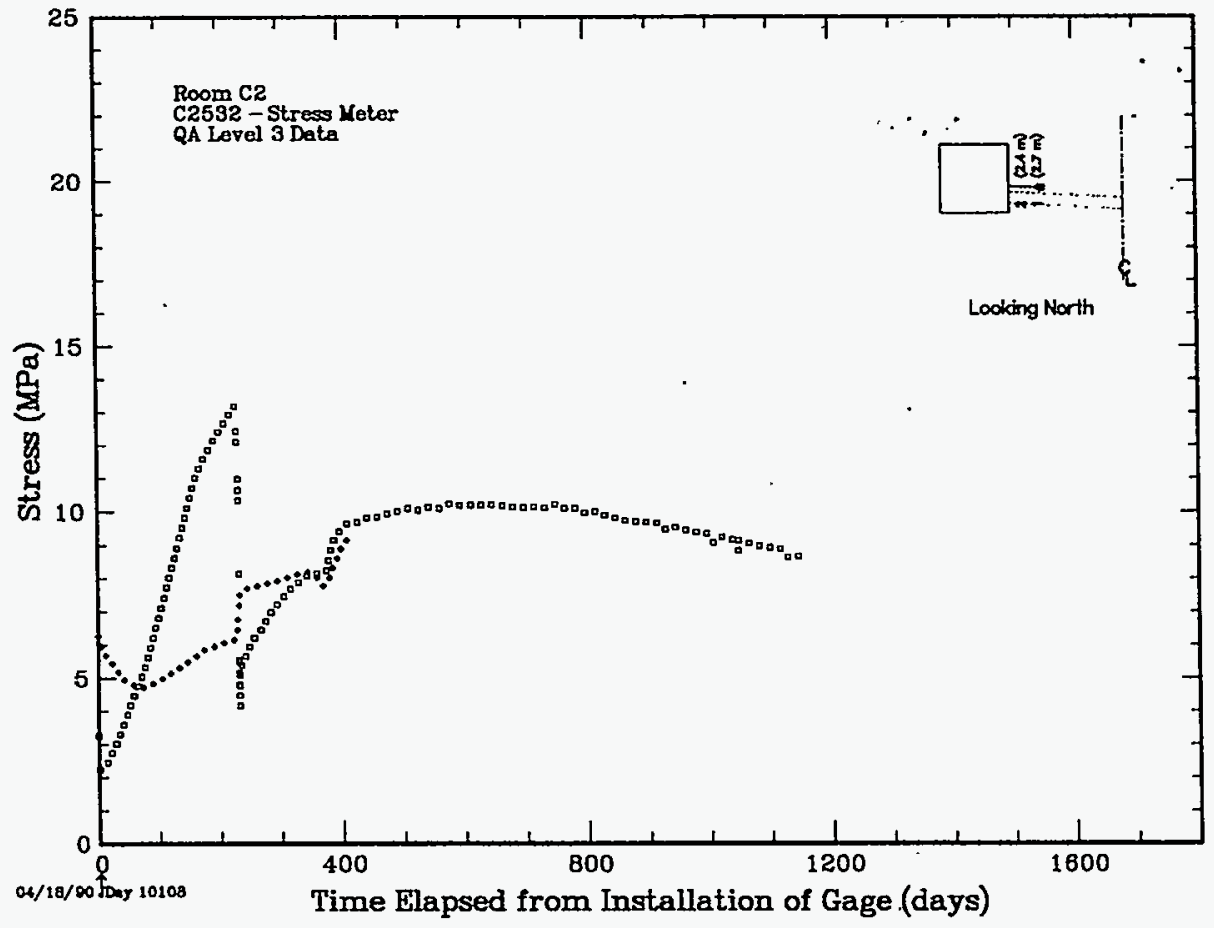

Figure 2.2.2nn. Stress Meter SGS Unit C2532 
Table 2.2.200. Stress Meter BuMines Unit C2641

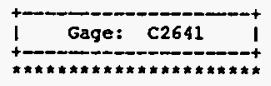

\#\#*** C2641 PI Comments *****

09/02/93 TLC: GTB (RANK $=10$ (1) $8(2), 10$ (3)) EXCEPT FOR GAGE -2 , THE DATA FROM THIS UNIT ARE OUTSTANDING. THIS BUMINES STRESS GAGE WAS INSTALIED 308 DAYS

BEFORE THE MINING OF THE INTERMEOIATE SCALE BOREHOLE. THE RESULTS OF IHE
MINTNG CAN BE SEEN STARTING AT DAY 308 WITH THE APPARENTLY ERRATIC BEHAVIOR OF THE UNIT. GAGE -2 FATLED 519 DAYS (JULIAN DATE 11183) AFTER IT WAS INSTALLED. NEARLY DAY 1120 . (COMPRESSION $2.84: 11$ (OEM)

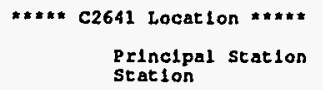

Gage Gage Rec D15

Number Type

C2641-1 STR P REM A $-9.21 \quad \begin{array}{cc}(m) & (m) \\ -4.23 & \end{array}$

$\begin{array}{llllll}\text { C2641-2 } & \text { STR } & \text { P REM } & \text { R } & -9.21 & -5.24 \\ \text { C2641-3 STR } & \text { P REM } & \text { H } & -9.21 & -5.85\end{array}$

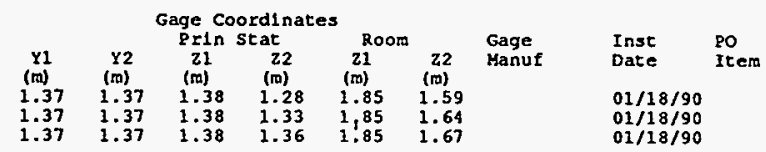

$01 / 18 / 90$
$01 / 18 / 90$

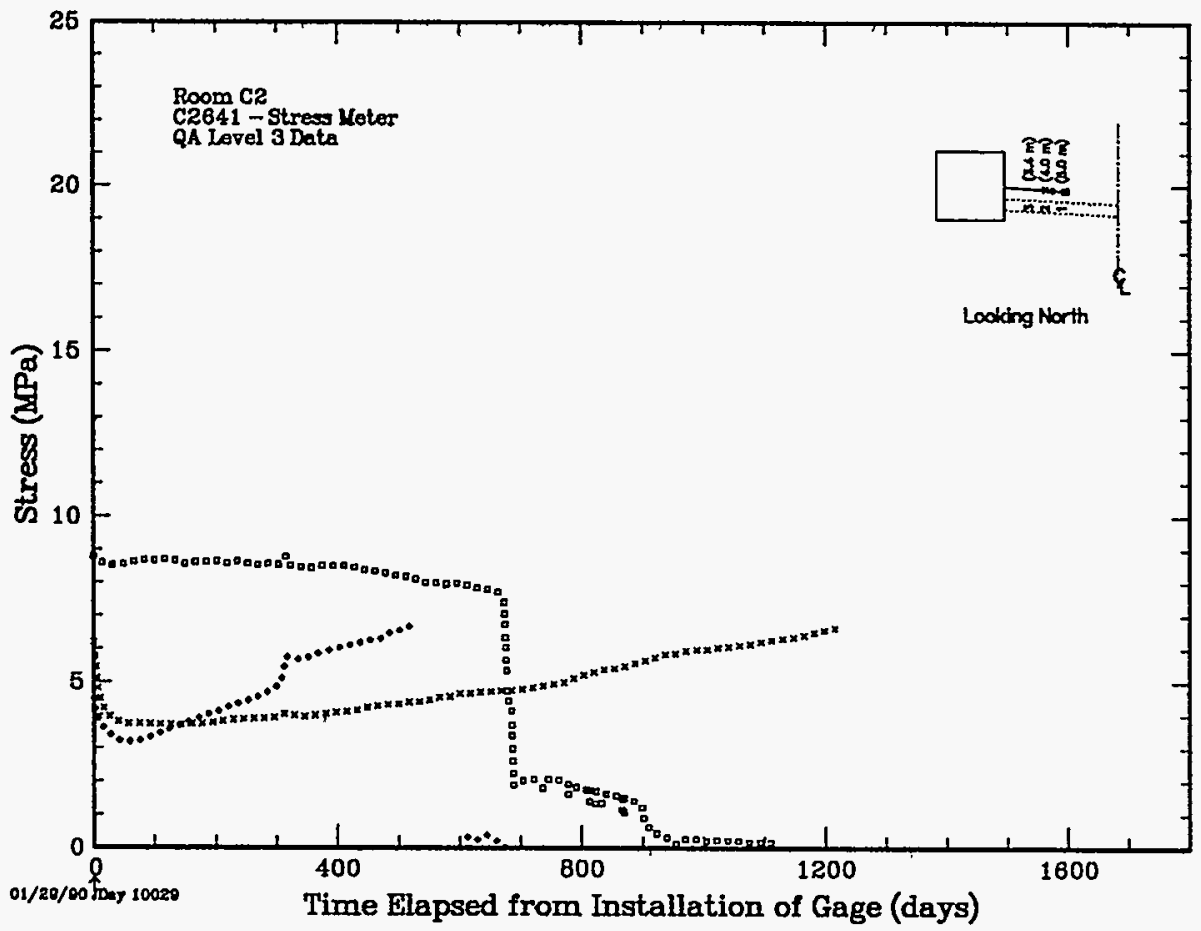

Figure 2.2.200. Stress Meter BuMines Unit C2641 
Table 2.2.2pp. Stress Meter BuMines Unit C2642

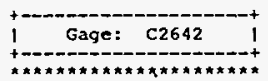

***** C2642 PI Comments *****

$09 / 02 / 93$ TLC: GTB [RANK $=4(1), 7(2), 6(3)$ ] THE BUMINES STRESS GAGE WAS INSTALLED 307 DAYS BEFORE MINING OF THE INTERMEDIATE SCALE BOREHOLE. GAGE -1 FAILED A 258 DAYS (JULTAN DATE 10288 ) AFTER INSTALLATTON. OAGE -3 FAILED AT 451 DAYS DELETED FROM DAY 173 TO 241 . SCATTER DUE TO A BAD PRESSURE TRANSDUCER WAS DELETED FROM GAGE -2 FROM DAY 399 TO 525 . ALTHOUGH THE MINING STARTED AT DAY 307. THE ERRATIC BEMAVIOR OF THE UNIT APPEARS TO OCCUR PRIOR TO THIS EVENT AND OBSCURES ANY STRESS CHANGES BECAUSE OF THE MINING. [COMPRESSION 1.44:1] (DEM)

A*** C2642 Location ***** Princlpal station
Station

Gage Gage Rec Dir

$\begin{array}{ccccc}\text { X1 } & \text { X2 } \\ \text { C2642-1 STR } & \text { P REM H } & (\mathrm{m}) & (\mathrm{m}) \\ & -9.20 & -4.21\end{array}$

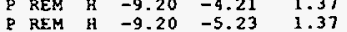

C2642-3 STR P REM H

Gage Coordinates

Prin stat Room Gage Inst Po

Comments

$01 / 23 / 90$

$01 / 23 / 90$

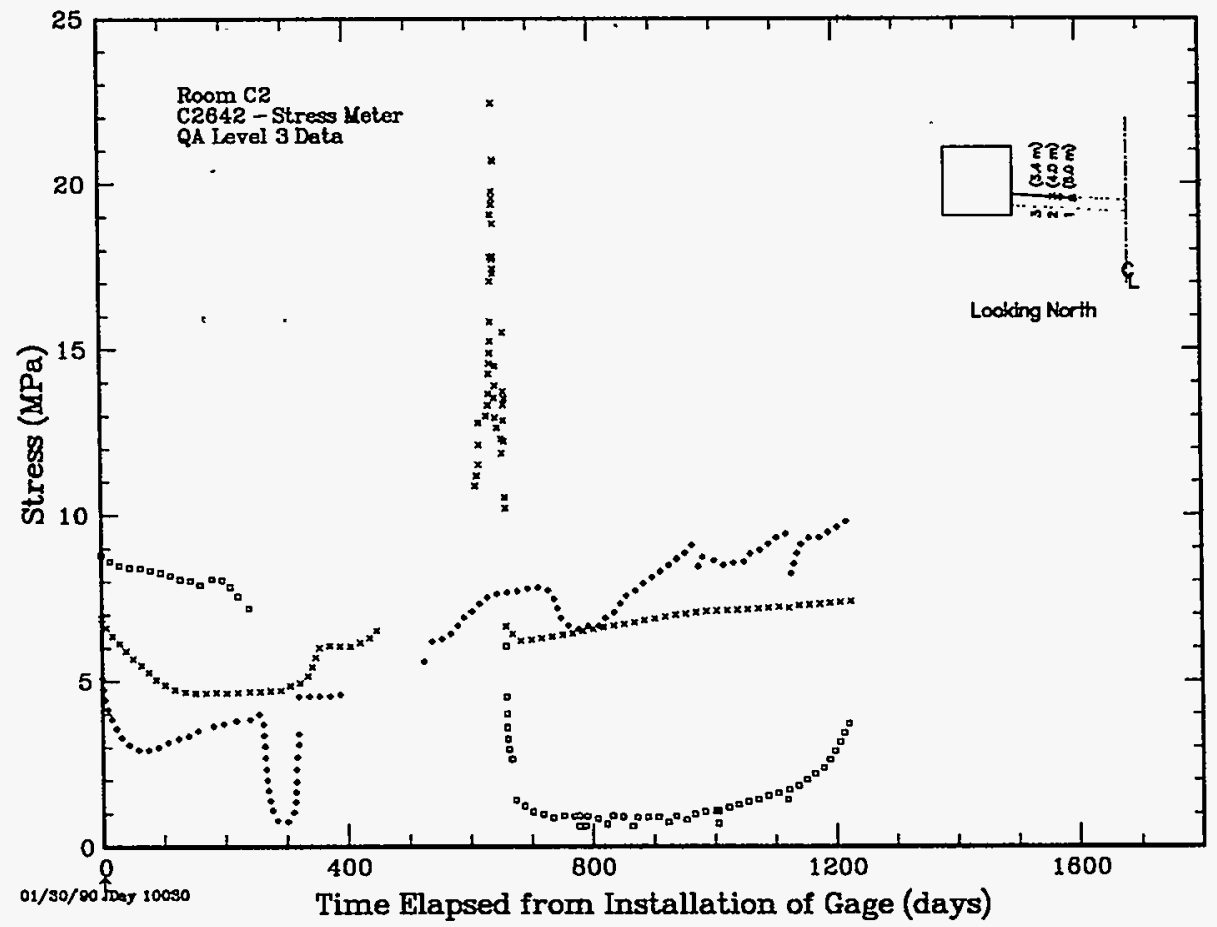

Figure 2.2.2pp. Stress Meter BuMines Unit C2642 
Table 2.2.2qq. Stress Meter BuMines Unit C2643

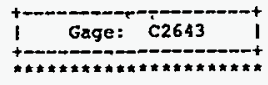

\#**A* C2643 PI Comsents *n*** 09/02/93 TLC:GTB (RANK $=4(1), 10(2), 6(3))$ THIS BUHINES STRESS GAGE YAS FAILPD AT THE START OF THE MINING. GAGE -2 FAILED JUST 15 DAYS SHORT OF A YEAR AFTRR THE MINING WAS COMPLETED, GAGE -3 FAILED AT DAY 399. THE RESULTS OF THE MINING CAN $9 E$ SEEN STARTING AT DAY 307 WITH THE ARPARENILY ERRATIC BEEAVIOR OF

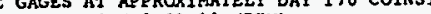

WITH ROOE BOLTING IN THE ROOH [COKPRESSIOH 2.01;1] (DEM)

***** C2643 Location \#*\#** Principal station
station

Gage Gago Rec Dir

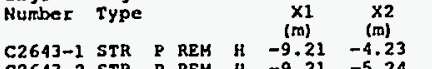

$\begin{array}{lllll}\text { C2643-2 STR } & \text { REM H } & -9.21 & -5.24 \\ \text { C2643-3 STR } & \text { REM } & -9.21 & -5.86\end{array}$

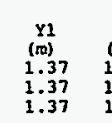

\begin{tabular}{ccc} 
& \multicolumn{3}{c}{ Gage Coordinates } \\
Prin & Stat \\
Y2 & Z1 & Z2 \\
(m) & (m) & $(\mathrm{m})$ \\
1.37 & 0.00 & -0.09 \\
1.37 & 0.00 & -9.04 \\
1.37 & 0.00 & -0.01
\end{tabular}

$\begin{array}{cc}\text { Room } & \\ z 1 & z 2 \\ (m) & (m) \\ 0.47 & 0.22 \\ 0.47 & 0.27 \\ 0.47 & 0.30\end{array}$

Gage

Gage

Inst

Po

Corments

$01 / 24 / 90$

$01 / 24 / 90$

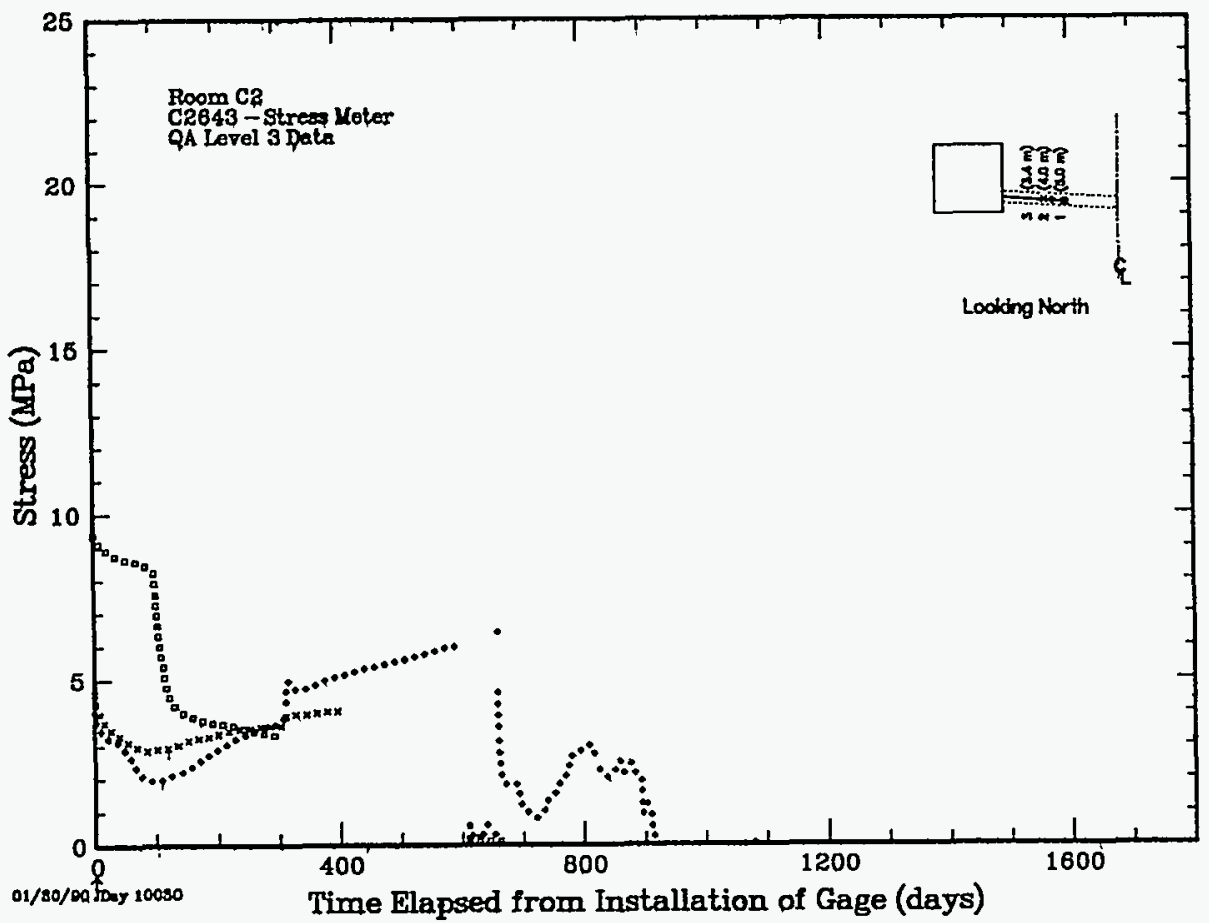

Figure 2.2.2qq. Stress Meter BuMines Unit C2643 
Table 2.2.2rr. Stress Meter BuMines Unit C2644

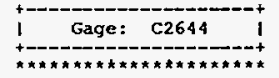

n*n. C2644 PI Comments w*n*

$09 / 02 / 93$ TLC:GTB [RANK $=7(1), 10(2), 2(3)$ ) THIS BUMINES STRESS GAGE WAS

INSTALLEO 308 DAYS BEFORE MINING OE THE INTERMEDIATE SCALE BOREHOLE. GAGE -1

EATLED 488 DAYS AFTER INSTALLATION. THE DATA FROM GAGE -1 SHOW AN IRREGULAR

BEHAVIOR AT THE TIME OF MINING OF THE BOREHOLE. GAGE -3 FAILED 150 DAYS AFTE

CHANGES IN THE MEASURED STRESSES IN THE GAGES OE THE UNIT. GAGE -2 EVENTUALLY

FAILED GRADUALLY ABOUT DAY BO0. [COMPRESSION 2.11:1] (DEM)

N*** C2644 Location *n***

Prlncipal station

Station

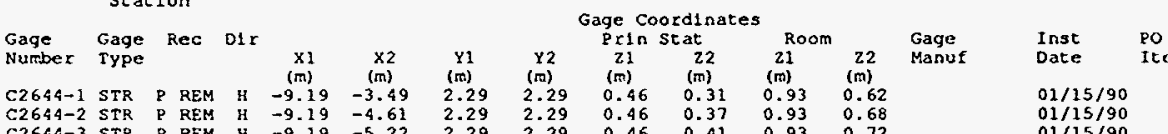

$\begin{array}{llllllllllll}\text { C2644-2 STRR } & \text { P REM } & \text { H } & -9.19 & -4.61 & 2.29 & 2.29 & 0.46 & 0.37 & 0.93 & 0.68 & 01 / 15 / 90 \\ \text { C2644-3 STR } & \text { P REM } & \text { H } & -9.19 & -5.22 & 2.29 & 2.29 & 0.46 & 0.41 & 0.93 & 0.72 & 01 / 15 / 90\end{array}$

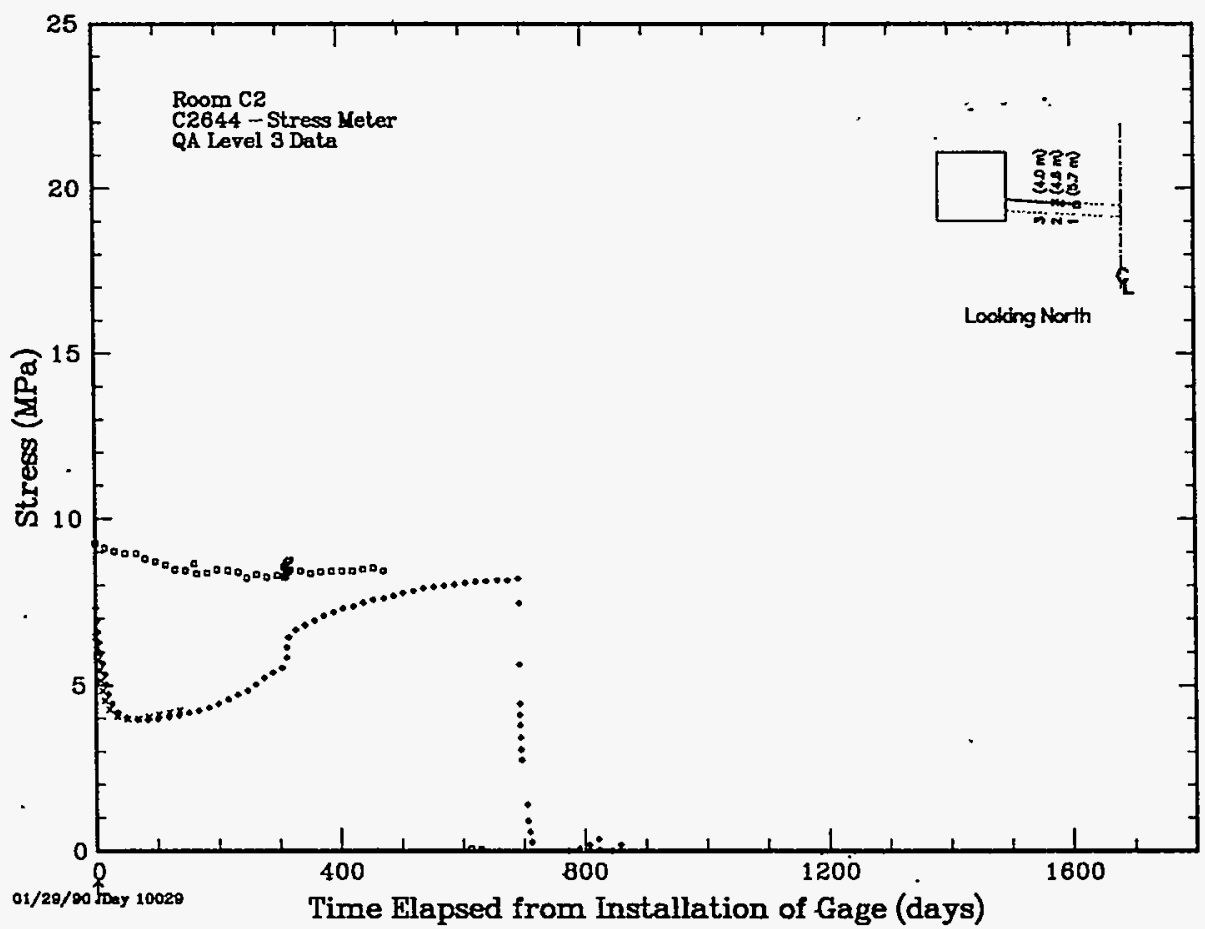

Figure 2.2.2rr. Stress Meter BuMines Unit C2644 
Table 2.2.2ss. Stress Meter BuMines Unit C2651

|che

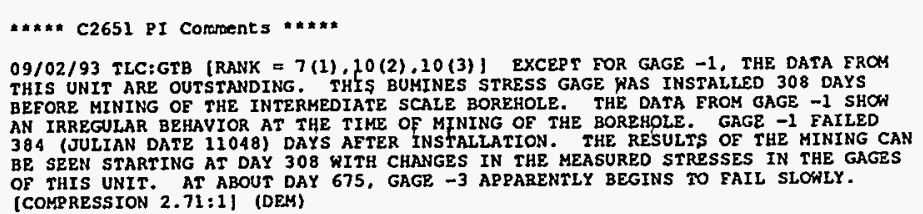

09/02/93 ILC: GTB [RANK $=7$ (1) 10 (2), 10 (3)] EXCEPY FOR GAGE -1, THE DATA FROM THIS UNIT ARE OUTSTANDING. IHIS BOMINES STRESS GAGE KAS INSTALIED 308 DAYS AN IRREGULAR QEHAYIOR AT THE TIME OF MINING OF THE BOREHOLE. GAGE -1 FAILED 384 (JUIAN DATE 11048 ) DAYS AFTER TANGES IN THE MEASURED STRESSES IN THE GAGES [COMPRESSION $2.71: 1$ ] (DEM)

**x** C2651 Location *****

$$
\begin{aligned}
& \text { Princlpal station } \\
& \text { station }
\end{aligned}
$$

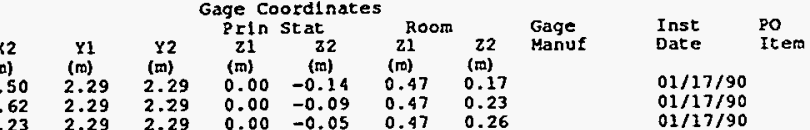

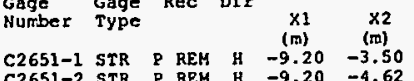

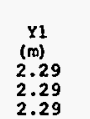

Comments $\begin{array}{llllllllllll}\text { C2651-2 STR } & \text { P RRM } & \text { H } & \mathbf{- 9 . 2 0} & \mathbf{- 4 . 6 2} & 2.29 & 2.29 & 0.00 & -0.09 & 0.47 & 0.23 & 01 / 17 / 90 \\ \text { C2651-3 STR } & \text { P REM } & \text { H } & -9.20 & -5.23 & 2.29 & 2.29 & 0.00 & -0.05 & 0.47 & 0.26 & 01 / 17 / 90\end{array}$

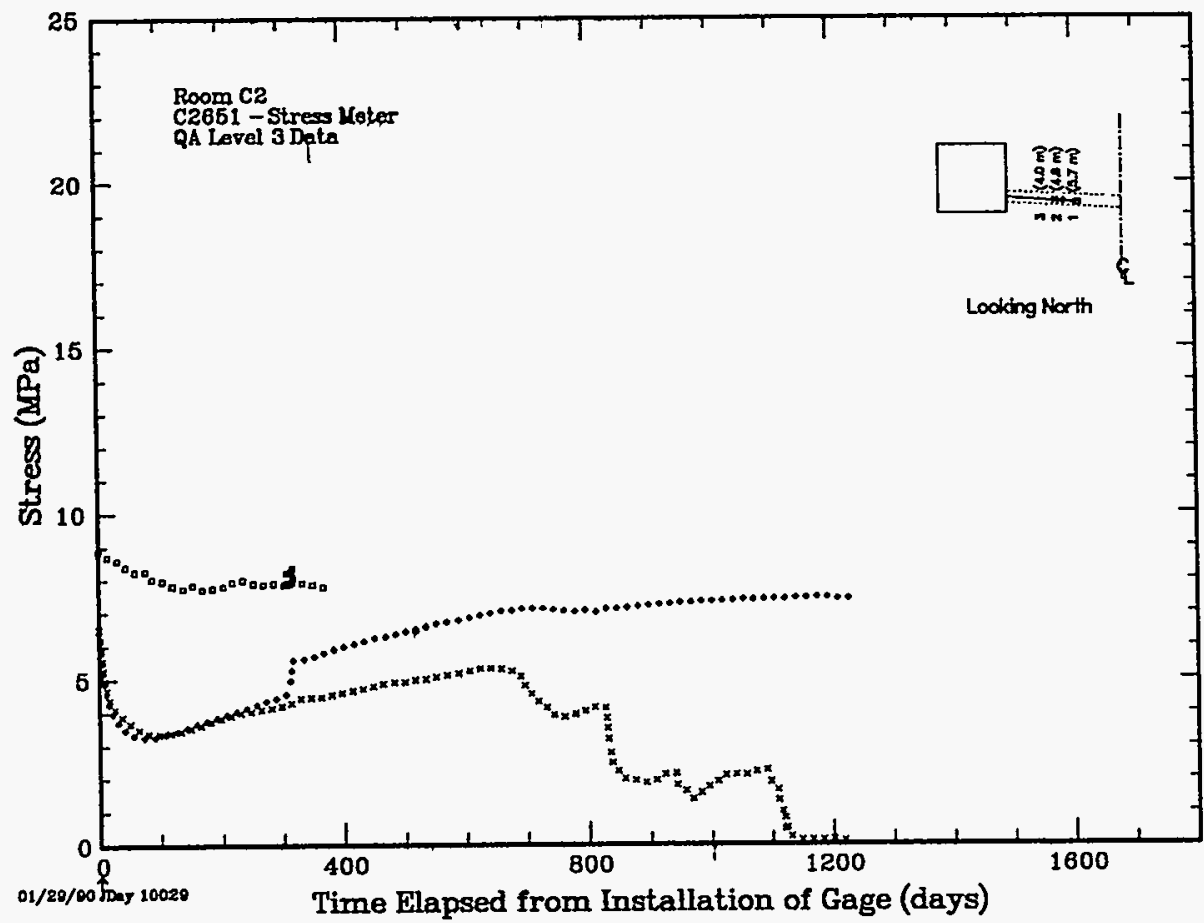

Figure 2.2.2ss. Stress Meter BuMines Unit C2651 
being normal to the plane of the BPC (finger jack) cell faces and along the axis of the CPC (cylindrical) cell. The directions of these unit normals can be further specified through the direction cosines in terms of their xyz coordinate system, which is oriented identically in space to the room XYZ coordinate system. The appropriate direction cosines are given in Table 5.2.3 for the SGS gages and Table 5.2.4 for the BuMines gages.

Historically, the measurement of stress fields around underground openings has been difficult and often controversial. This situation is compounded in salt because of the time dependent creep processes occurring around the underground, stressed opening. The scale of the opening does not alter this behavior, and the small diameter gage-emplacement borehole experiences the same phenomena as the large drift or room. As a consequence, any stress meter emplaced in the salt will give a response reflecting both time dependent conditions around the emplacement hole and the time dependent conditions around the room. The nature of these conditions is such that after a period of time and in the absence of three-dimensional effects on the gage, a stress meter will theoretically come into equilibrium with the stress field in the pillar. In most of the applications where the gage is installed after the excavation, this equilibrium is then what we are looking for in the stress meter data. The gage is attempting to measure the absolute field stress. This equilibrium condition can be very difficult to achieve. However, interestingly, the Intermediate Scale Borehole Test presented an opportunity to use the gage in a relative rather than absolute sense.

For the Intermediate Scale Borehole Test, the stress meters were installed to monitor the change in the stress field due the drilling of the borehole. The gages were installed early to allow the rapid initial 
Table 5.2.3. Direction Cosines for Unit Normals of SGS Stress Meters

Unit

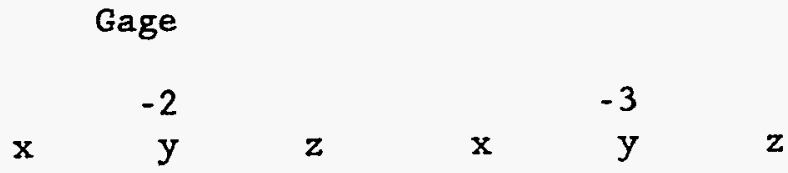

C ST-06

$\begin{array}{llllllll}\text { C_521 } & 0.0 & 0.0 & +1.0 & +1.0 & 0.0 & 0.0 & \text { No gage } \\ \text { C_522 } & 0.0 & 0.0 & +1.0 & +1.0 & 0.0 & 0.0 & \text { No gage } \\ \text { C_523 } & 0.0 & 0.0 & +1.0 & +1.0 & 0.0 & 0.0 & \text { No gage } \\ \text { C_524 } & 0.0 & 0.0 & +1.0 & +1.0 & 0.0 & 0.0 & \text { No gage } \\ \text { C_525 } & 0.0 & 0.0 & +1.0 & +1.0 & 0.0 & 0.0 & \text { No gage } \\ \text { C_526 } & 0.0 & 0.0 & +1.0 & +1.0 & 0.0 & 0.0 & \text { No gage } \\ \text { C_531 } & 0.0 & 0.0 & +1.0 & +1.0 & 0.0 & 0.0 & \text { No gage } \\ \text { C_532 } & 0.0 & 0.0 & +1.0 & +1.0 & 0.0 & 0.0 & \text { No gage } \\ \text { C_533 } & 0.0 & 0.0 & +1.0 & +1.0 & 0.0 & 0.0 & \text { No gage } \\ \text { C_534 } & 0.0 & 0.0 & +1.0 & +1.0 & 0.0 & 0.0 & \text { No gage } \\ \text { C2523 } & 0.0 & 0.0 & +1.0 & 0.0 & +1.0 & 0.0 & \text { No gage } \\ \text { C2524 } & 0.0 & 0.0 & +1.0 & 0.0 & +1.0 & 0.0 & \text { No gage } \\ \text { C2525 } & 0.0 & 0.0 & +1.0 & 0.0 & +1.0 & 0.0 & \text { No gage } \\ \text { C2531 } & 0.0 & 0.0 & +1.0 & 0.0 & +1.0 & 0.0 & \text { No gage } \\ \text { C2532 } & 0.0 & 0.0 & +1.0 & 0.0 & +1.0 & 0.0 & \text { No gage }\end{array}$

C ST 00

$\begin{array}{llllllll}\text { C_561 } & 0.0 & 0.0 & +1.0 & +1.0 & 0.0 & 0.0 & \text { No gage } \\ \text { C_562 } & 0.0 & 0.0 & +1.0 & +1.0 & 0.0 & 0.0 & \text { No gage } \\ \text { C_563 } & 0.0 & 0.0 & +1.0 & +1.0 & 0.0 & 0.0 & \text { No gage } \\ \text { C_564 } & 0.0 & 0.0 & +1.0 & +1.0 & 0.0 & 0.0 & \text { No gage } \\ \text { C_565 } & 0.0 & 0.0 & +1.0 & +1.0 & 0.0 & 0.0 & \text { No gage } \\ \text { C_566 } & 0.0 & 0.0 & +1.0 & +1.0 & 0.0 & 0.0 & \text { No gage } \\ \text { C_571 } & 0.0 & 0.0 & +1.0 & +1.0 & 0.0 & 0.0 & \text { No gage } \\ \text { C_572 } & 0.0 & 0.0 & +1.0 & +1.0 & 0.0 & 0.0 & \text { No gage } \\ \text { C_573 } & 0.0 & 0.0 & +1.0 & +1.0 & 0.0 & 0.0 & \text { No gage } \\ \text { C_574 } & 0.0 & 0.0 & +1.0 & +1.0 & 0.0 & 0.0 & \text { No gage } \\ \text { C1561 } & 0.0 & 0.0 & +1.0 & 0.0 & +1.0 & 0.0 & \text { No gage } \\ \text { C1562 } & 0.0 & 0.0 & +1.0 & 0.0 & +1.0 & 0.0 & \text { No gage } \\ \text { C1563 } & 0.0 & 0.0 & +1.0 & 0.0 & +1.0 & 0.0 & \text { No gage } \\ \text { C1571 } & 0.0 & 0.0 & +1.0 & 0.0 & +1.0 & 0.0 & \text { No gage } \\ \text { C1572 } & 0.0 & 0.0 & +1.0 & 0.0 & +1.0 & 0.0 & \text { No gage }\end{array}$


Table 5.2.4. Direction Cosines for Unit Normals of BuMines Stress Meters

Unit

$x \quad \begin{array}{cc}-1(C P C) \\ y\end{array}$

Gage
$x \quad \begin{gathered}(B P C) \\ y\end{gathered} \quad z$

C ST-03

\begin{tabular}{llllllllll} 
C_641 & 0.0 & +1.0 & 0.0 & 0.0 & 0.0 & +1.0 & +1.0 & 0.0 & 0.0 \\
C_642 & 0.0 & +1.0 & 0.0 & 0.0 & 0.0 & +1.0 & +1.0 & 0.0 & 0.0 \\
C_643 & 0.0 & +1.0 & 0.0 & 0.0 & 0.0 & +1.0 & +1.0 & 0.0 & 0.0 \\
C_644 & 0.0 & +1.0 & 0.0 & 0.0 & 0.0 & +1.0 & +1.0 & 0.0 & 0.0 \\
C_645 & 0.0 & +1.0 & 0.0 & 0.0 & 0.0 & +1.0 & +1.0 & 0.0 & 0.0 \\
C_646 & \multicolumn{1}{c}{ Not installed } & 0.0 & 0.0 & +1.0 & +1.0 & 0.0 & 0.0 \\
C_651 & 0.0 & +1.0 & 0.0 & 0.0 & 0.0 & +1.0 & +1.0 & 0.0 & 0.0 \\
C_652 & 0.0 & +1.0 & 0.0 & 0.0 & 0.0 & +1.0 & +1.0 & 0.0 & 0.0 \\
C_653 & 0.0 & +1.0 & 0.0 & 0.0 & 0.0 & +1.0 & +1.0 & 0.0 & 0.0 \\
C_654 & Not installed & 0.0 & 0.0 & +1.0 & +1.0 & 0.0 & 0.0 \\
C2641 & +1.0 & 0.0 & 0.0 & 0.0 & 0.0 & +1.0 & 0.0 & +1.0 & 0.0 \\
C2642 & +1.0 & 0.0 & 0.0 & 0.0 & 0.0 & +1.0 & 0.0 & +1.0 & 0.0 \\
C2643 & +1.0 & 0.0 & 0.0 & 0.0 & 0.0 & +1.0 & 0.0 & +1.0 & 0.0 \\
C2644 & +1.0 & 0.0 & 0.0 & 0.0 & 0.0 & +1.0 & 0.0 & +1.0 & 0.0 \\
C2651 & +1.0 & 0.0 & 0.0 & 0.0 & 0.0 & +1.0 & 0.0 & +1.0 & 0.0
\end{tabular}

stress transients common in these gages to subside as the changes in the local stress fields around the gage boreholes diminish. Please remember, that even under these conditions the gage is not in equilibrium and reflects a response to a very complex and changing stress field. When the coring operation was performed, the stress field undergoes a transient change, part of which will be essentially instantaneous. This change is measured by the response of the gages.

The first stress gage was installed on $1 / 18 / 90$. The last stress gage (C_646) was installed on $8 / 28 / 90$, approximately four months before the start of the borehole coring operations. The rather extended time period over which the gages were installed was caused by both delays in drilling 
of the instrument holes due to crew availability and procurement delays of gages when the number of gages increased during the fielding process.

The SGS gages had an initial platen force applied equivalent to the lithostatic pressure of $14.8 \cdot \mathrm{MPa}(2140 \mathrm{psi})$. This force very quickly relaxed to a much lower value, and then the veftical stress and horizontal stress on several, but not all, gages gradually increased. The horizontal stress did not show as much adjustment to the in situ stress conditions as the vertical stress measurements.

BuMines gages showed similar response curves. Initial pressurization to the estimated lithostatiic stress magnitude of $14.8 \mathrm{MPa}$ (2150 psi) is rapidly relaxed to a much lower value. Then the pressure reverses and gradually increases, up to the time of the drilling of the intermediate scale borehole, which caused a change in the stress. The change in stress may be positive or negative depending on the orientation of the gage and its. relative position to the borehole.

In most cases the start of recording of the gage response was delayed for sope time after the installation date. This means that often the early part of the gage transient was lost. Because of this delay between gage installation and activation of the data acquisition process, the initial gage readings do not indicate the rapid transient from the initial loading condition.

The vertical stress along the vertical centerline of the borehole was observed to decrease as a result of the borehole excavation. The decrease in the vertical stress component was inversely proportional to the radial distance from the center of the borehole. That is, a greater decrease was measured at a radial distance of $1 \mathrm{~m}(3 \mathrm{ft})$ than at $2 \mathrm{~m}(6 \mathrm{ft})$. Vertical stress decrease was also greater at greater distances from the midpillar, 
Station 0 , of the borehole. Thus, the vertical stress decrease at station -6 was greater than the decrease observed at Station 0 . The vertical stress along the horizontal centerline of the borehole was observed to increase due to the borehole excavation. Vertical stresses tended to increase in the zone defined by this horizontal plane and a plane inclined by 45 degrees on the north side of the borehole. Vertical stresses tended to increase on the south side of the borehóle but the zone was defined by a vertical plane at the edge of the borehole (i.e. $Y=-0.5 \mathrm{~m} \cdot(-1.5 \mathrm{ft})$ ). Thus, the vertical stress field changed asymmetrically.

The horizontal stress component in the Y-direction tended to be less than the horizontal stress component in the $\mathrm{X}$-direction. This was found by comparing the change in the horizontal stress component as measured by the gages installed from the $\mathrm{N} 1420 \mathrm{drift}$ as opposed to gages installed from Room $\mathrm{C} 1$ and $\mathrm{C} 2$. The $\mathrm{X}$-component of horizontal stress tended to change less than $+/-1 \mathrm{MPa}$, except at locations within two radii from the borehole centerline. This was observed at Station 0 and at station -6 . The $\mathrm{Y}$-component of horizontal stress tended to increase in the zone defined by a plane inclined to the horizontal by 45 . degrees to the north side and the south side of the borehole. 
5.3 Strain Measurements: Some very special gages were fielded in the Intermediate Scale Borehole Test that were intended to measure the closure of the pilot hole. These strain gages were actually cantilever beams Instrumented with a strain gage to monitor the beam deflection, and hence, the amount of hole closure. For each unit, one cantilever beam monitored vertical closure, while another monitored horizontal closure. Initially, these gages were to have been installed in the pilot hole as soon as the completion of the hole; however, gage development problems prevented the gages from being ready until just before the intermediate scale borehole was drilled. These gages were to record the early time displacement of paterial in front of the approaching excavation of the material of the intermediate scale borehole. Typically, because these displacements in the as yet to be excavated material in front of the mining or drilling face cannot be obtained except by calculation [29], these measurements are quite unique. However, difficulty with the gages has resulted in not very clean reçords, and the data remain uncertaip.

Table 5.3.1 shows schematically the locations of the strain gage units. The gage locations are given in Table 5.3.2a-d and the measured data in Figures 5.3.1a-d:

The pilot hole was drilled between $11 / 29 / 89$ and $11 / 30 / 89$. The first strain gage (C2S01) was installed on 11/20/90, followed by C2S21, C2S42, and C2S63 installed on $12 / 4 / 90,12 / 6 / 90$, and $12 / 7 / 90$, respectively. The main intermediate hole coring was started on $12 / 3 / 90$ and completed on 12/13/90. Data for C2S21 indicates an almost instantaneous vertical closure of more $1.75 \mathrm{~mm}(0.069$ in.) and a horizontal closure of $1.5 \mathrm{~mm}$ (0.059 in.) on day 3 after installation. This jump occurred at the time of the overcoring of the location of the strain gages. The gages were 
Table 5.3.1. Strain Gage Units (Gages) Location Guide
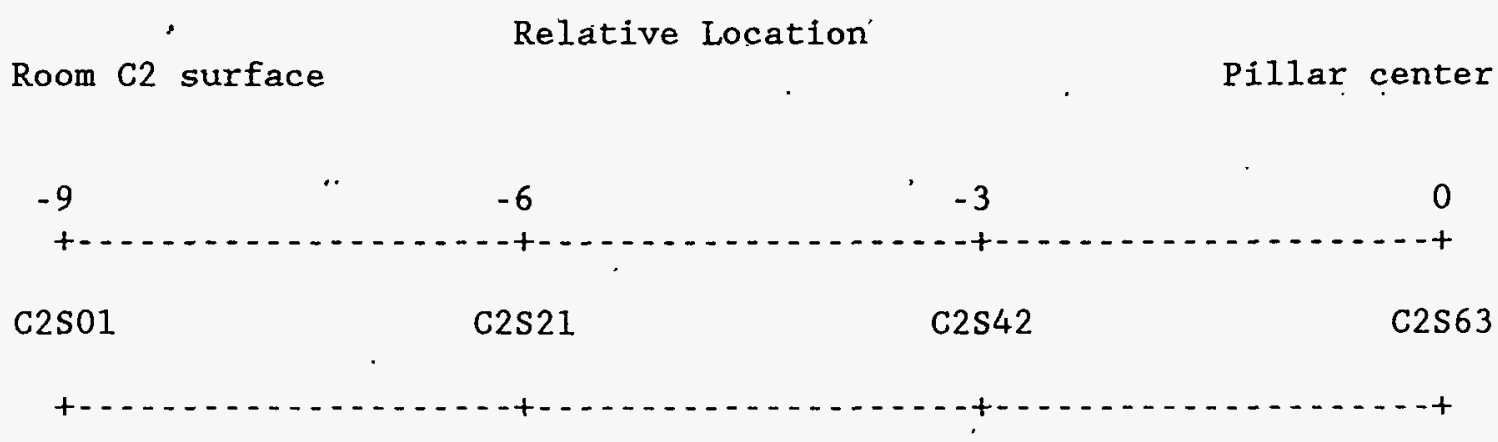

destroyed at the time of overcoring. In the same manner, data for C2S42 indicates an almost instantaneous vertical closure of $1.5 \mathrm{~mm}(0.059 \mathrm{in.})$ and horizontal closure of $1.0 \mathrm{~mm}(0.039$ in.) just about a day after gage installation. Again the jump coincides with the overcoring of the gage location. The two remaining strain gages have too few data points from which to draw any general observations. The data for these gages was very limited and the gages were destroyed as the coring operation progressed past the location of the gage installation. Whether or not a specific gage produced data is probably closely related to the chance that the sequence of the overcoring operation did not overcore and destroy the gage within a single length of core.

Although there are really quite limited data from these gages, those gages that gave data produced results very consistent with what would be expected. However, the data should be used with some care.

[text continues on page 167] 
Table 5.3.2a. Strain Gage Unit C2S01

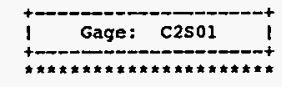

a*t** c2S01 PI Corrsents *A***

06/03/92 TLC [RANK = 10 (1), 10 (2)] THIS STRAIN UNIT HAS INSTALLED IN THE 47.6

MM DIAHERER PYLOT HOLE 6 DAYS BEFORE MINING OE THE INTERMEOIATE SCALE BOREHOLE.

IN ONLY THREE DATA POINTS. ALTHOUGH THE DISPLACEMENTS SHOULD BE IN GENERAL

RELATED TO THOSE OBSERVED IN THE LARGER HOLE, IT IS DIFEICULT TO DRAW SUCH A

CONCLUSION FROE SO FEH DATA. BOTH THE VERTICAL AND HORIZONTAL DISPLACEMENTS

ARE ESSENTIALLY 2ERO, GHICH IS SOMEWHAT IN AGREEMENT WITH THE OBSERVATION OF
CLOSURE IN THE THE LARGER HOLE. [COMPRESSICN 9.24:1] (DEM)

**** C2S01 Location *****

\section{Principal station} Station

Gage Gage Rec DIr

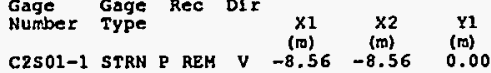

$\begin{array}{llllllr}\text { C2S01-1 STRN P REM } & V & -8.56 & -8.56 & 0.00 \\ \text { C2S01-2 STRN P } & \text { REM } & \text { H } & -8.41 & -8.41 & -0.06\end{array}$

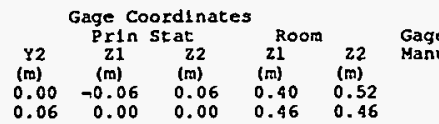

Inst Po

Corarents

$11 / 20 / 90$
$11 / 20 / 90$

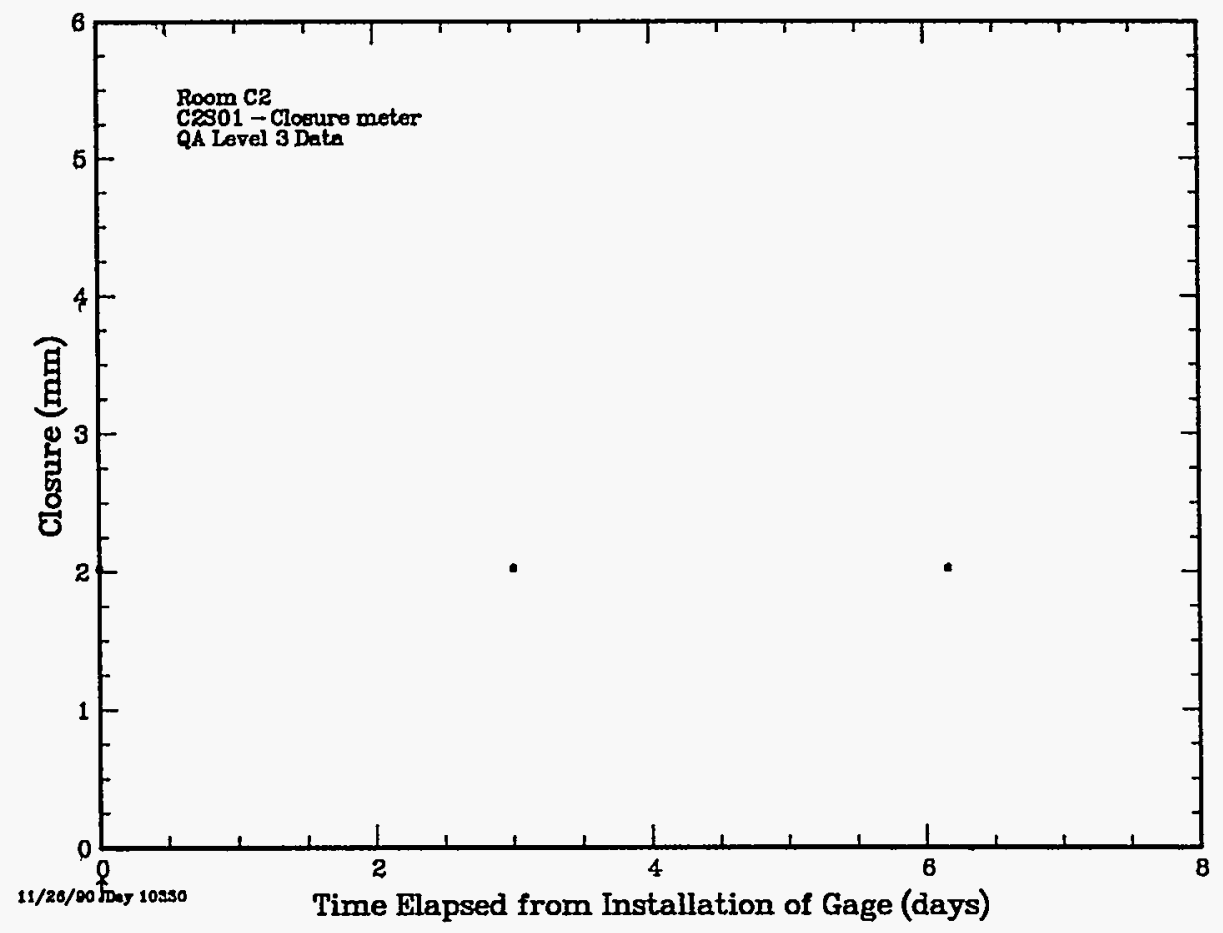

Figure 5.3.1a. Strain Gage Unit C2S01 
Table 5.3.2b. Strain Gage Unit C2S21

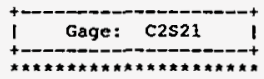

***** C2S21 PI Compents $* \star * * *$

06/03/92 TLC (RANK $=10(3), 10(2)$ ) THIS STRAIN UNIT WAS INSTALLED IN THE 47.6 MM DIAMETER PILOT HOLE ON THE FIRST DAY OF MINING OE THE LARGER DIAMETER INTERMEDIATE SCALE BOREHOLE. THE UNIT WAS MINED OUT BY THE CORE DRILL SOME 4

DAYS LATER AFTER PROOUCING A TOTAL OF 16 DATA POINTS. ALTHOUGH THE DATA APPEAR

TO BE CONSISTENT WITH THE DATA TREND OE THE LARGER HOLE CLOSURE, SCATTER

SMALL NUMBER OE POINTS MANES

***** C2S21 Locat lon *****

Principal station

station

Gage Coordinates

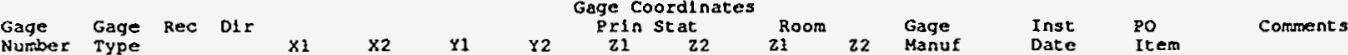

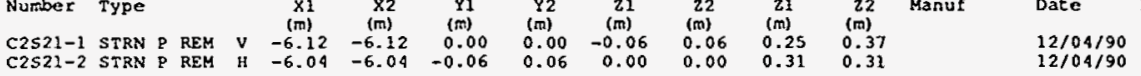

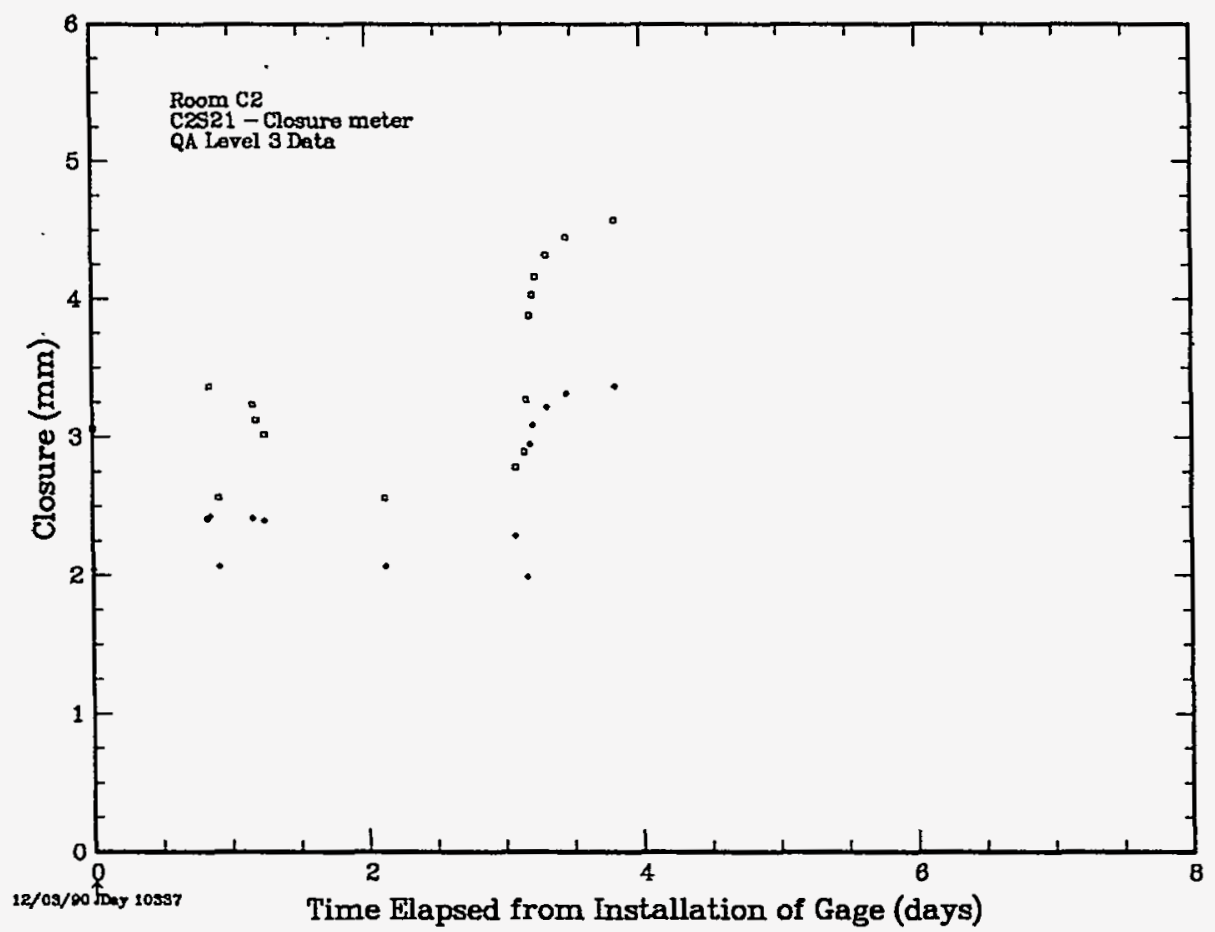

Figure 5.3.1b. Strain Gage Unit C2S21 
Table 5.3.2c. Strain Gage Unit C2S42

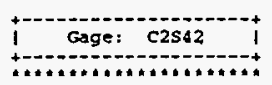

..... c2s42 PI coments .....

06/03/92 TLC [RANK $=10(1) .10(2)]$ THIS STRAIN UNIT WAS INSTALLED IN THE 47.6

POM DIAKETER PILOT HOLE WHICH WAS THE GUIDE FOR THE CORE DRILL BIT. IT WAS

INSTALLED 3 DAYS AFTER THE START OF MINING OF THE TMERHEE

THE UNIT WAS DRILLED OUT FO DAYS LATER APR TKE LARGER HOLE; HOWEVRR, THE DATA ARE QUITE LIMTTED AND SHOW SOME SCATTER.

ICOMPRESSION $0.80: 1$ ) (DEM)

..... c2sa2 Location... ..

Prinezpal station

Stacion seation Gage Coordinates

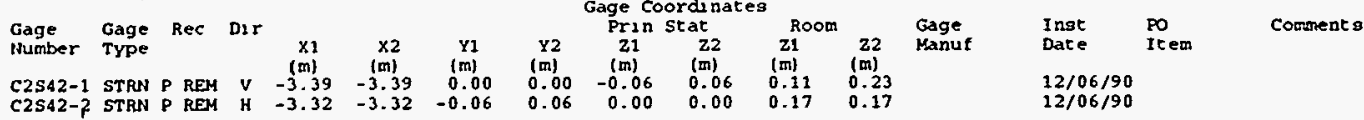

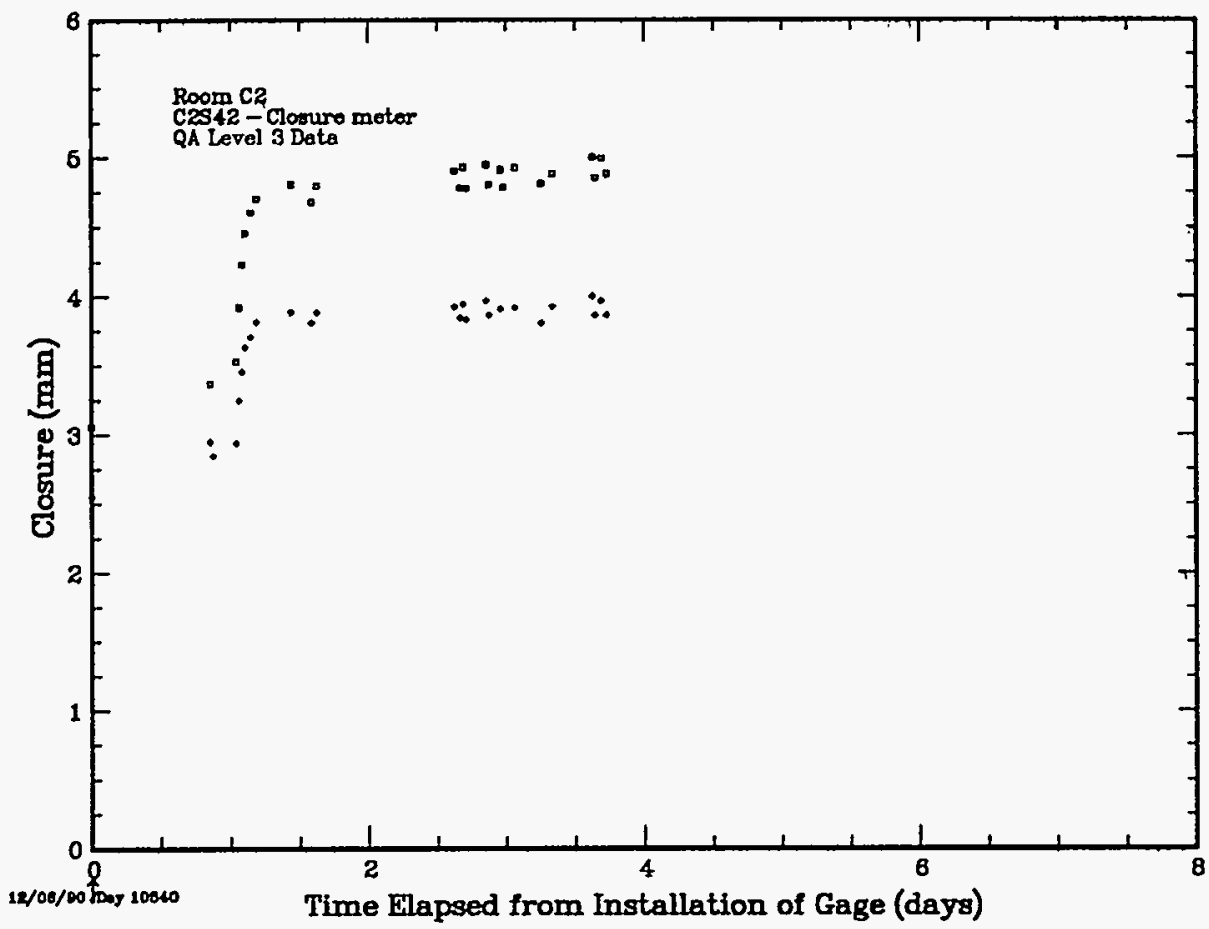

Figure 5.3.1c. Strain Gage Unit C2S42 
Table 5.3.2d. Strain Gage Unit C2S63

Gage: $\cos 63$ |

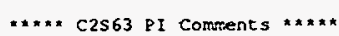

06/03/92 ILC [RANK $=10(1), 10(2)$ ] THIS STRAIN UNIT WAS INSTALLED IN THE 47.6

MM DIAMETER PILOT HOLE WHICH GUIDED THE CORING BIT. IT WAS INSTALIED SCHE 4

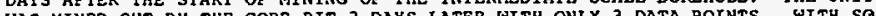

WAS MINED OUT BY THE CORE BI INTERPRETATION OF THE DATA IS NOT REALLY POSSIBLE.

[COMPRESSION $4.34: 1$ ] (DEM)

***** C2S63 Location *****

Princlpal station

Gage Coordinates

Gage Gage Rec D1r

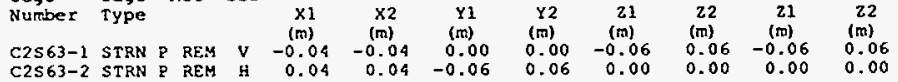

\begin{tabular}{|c|c|c|}
\hline $\begin{array}{l}\text { Gage } \\
\text { Manuf }\end{array}$ & $\begin{array}{l}\text { Inst } \\
\text { Date }\end{array}$ & $\begin{array}{l}\text { Po } \\
\text { Item }\end{array}$ \\
\hline & $\begin{array}{l}12 / 0 \\
12 / 0\end{array}$ & \\
\hline
\end{tabular}

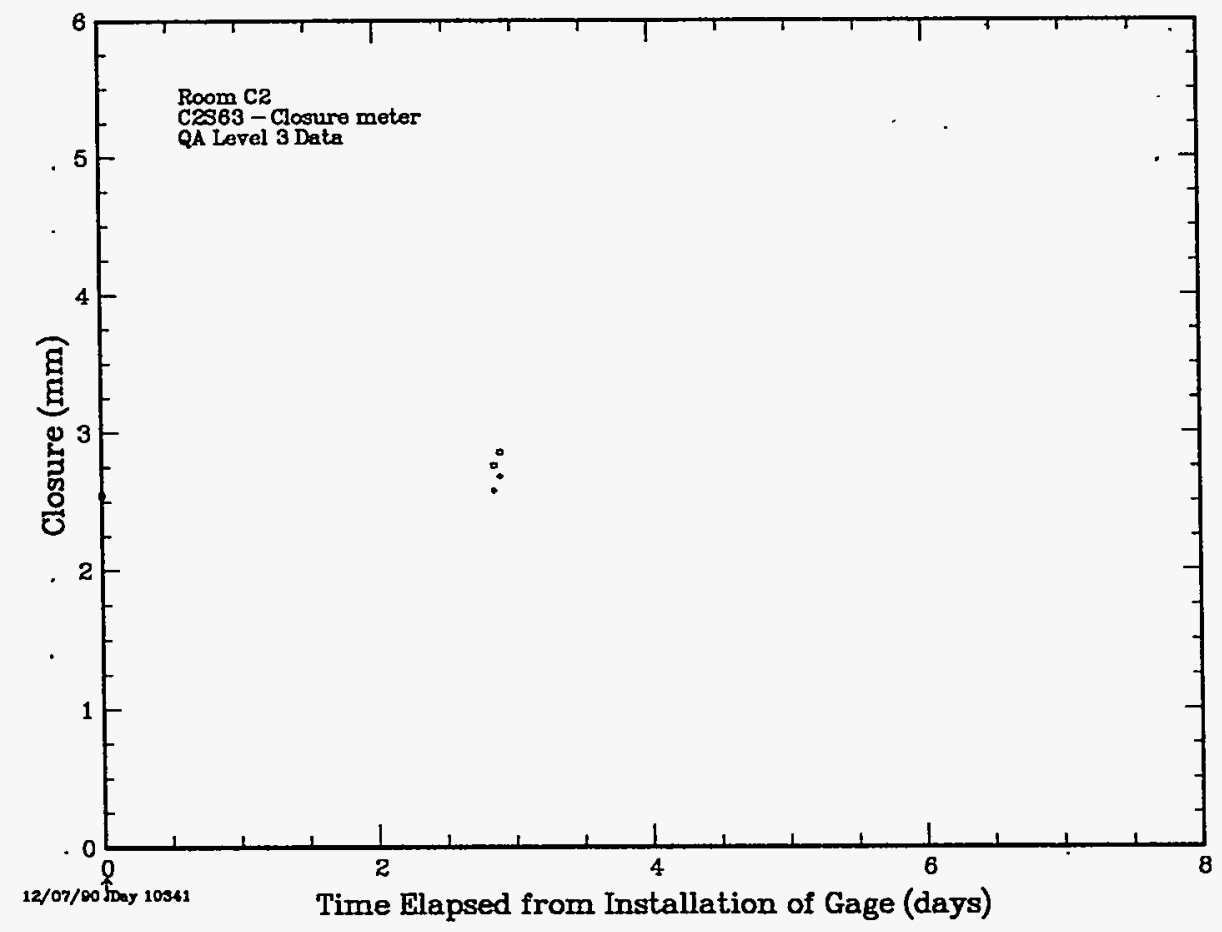

Figure 5.3.1d. Strain Gage Unit C2S63 


\section{INTERPRETATION AIDS}

Interpretation of data from the TSI in situ tests involves some interesting but often ignored or unrecognized factors related ta the time-dependent response of salt. If these factors are not considered, failure to accurately predict observed in situ behavior may result. Certainly, ignoring these factors can be a source of confusion in interpretation of numerical studies. Therefore, before a meaningful analysis of the in situ data is undertaken, these factors must be understood.

First, the analyst should realize that in situ data may represent only part of the displacements that have occurred during the mining of an opening and only part of the stress histories that have been induced around the opening. Proper interpretation requires that the investigator or analyst avoid the temptation to assume virgin conditions before measurements began. Instead, the analyst must minimize the "lost" or "unmeasured" displacements as much as possible and recognize the influence of fielding activity on both stress and temperature measurements. In turn, the numerical analyst must become aware of the consequences of model abstractions and assumptions that have been introduced into calculations, but which may not adequately represent in situ conditions.

The displacement results in this report were obtained with every care taken to reduce the "lost" early time displacements to as small a quantity as possible. Furthermore, the interpretation recognizes where the lost displacements may reside. Schematically, the reconstruction of salt displacements for both closures and extensometers can be visualized in terms of the trajectory of a material point in the salt as the mining face of an opening approaches, passes, and recedes from the plane of the 
point. If the face velocity is not a function of time, the points move in time according to the constitutive laws for salt creep. (A non-constant face velocity introduces an additional pseudo-time-dependent term.)

Figure 6.0.1 illustrates such a trajectory. The two material points marked $E^{\prime}$ and $C$, represent an extensometer anchor and a closure point, respectively. Trajectory lines for vertical displacements are drawn through the two points. For both points $E^{\prime}$ and $C$, it is seen that the points undergo vertical displacements before the mining face reaches them. These displacements are the result of the far-field stress-strain influence of the opening in the surrounding salt and can be measured only under very special conditions. Usually, the deformation in front of the mining face is often unrecognized and typically unmeasured. The deep anchor, point $E$, is deep enough that it does not move within the time frame of the figure; however, eventually this anchor will move also.

Notice that point $\mathrm{C}$ actually starts at a position above the eventual line of the opening, but as the face approaches the plane of the point, displacement brings the point down to become a surface point. The point displacements in advance of the mining face cannot be measured because the mining operation essentially mines out the displaced material. After the mining face has passed, both points $E^{\prime}$ and $C$ continue to displace with time. Now, however, the investigator can install instruments to measure the displacements.

It is important to remember that the points continue to displace from creep even though the face advance may hesitate or stop. As an example, the time of gage installation is represented on the trajectory. At the WIPP, the early mining sequence closure gages were installed within about a meter of the mining face and within less than an hour of the opening of 
国

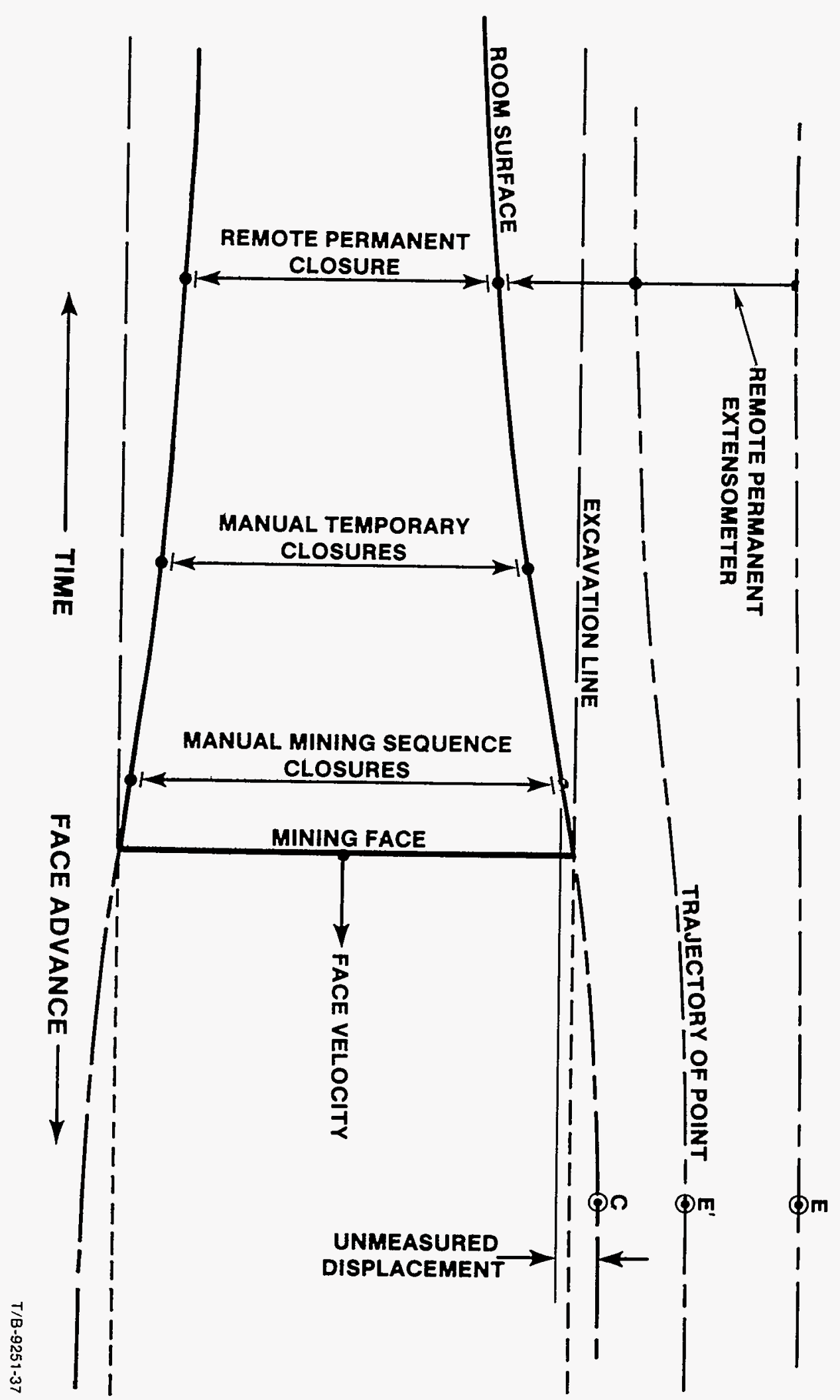


the intended gage station. This situation is noted on the trajectory curve for surface point C. As operations permitted, the mining sequence gages were supplemented by the temporary closure gages, as shown. Again, as operations and hole drilling permitted, the permanent closure stations were established and, for the first time in this sequence, permanent extensometer installations were made. It is clear that the delay results in a significant "lost" displacement, as is apparent in the point E' trajectory.

Recognizing the events described above permits the reconstruction of the measured and "unmeasured" displacements in an abstract sense. Such reconstructions are illustrated for closure measurements in Figure 6.0.2 and for extensometer measurements in Figure 6.0.3. Figure 6.0.3 adds a deep extensometer point", E, to show its treatment. It is often difficult in actual reconstruction of extensometer displacements to evaluate the unmeasured displacements, especially where there were significant delays in instrument installation. Even under optimum installation condition, the extensometers will have more unmeasured displacements and therefore be more difficult to reconstruct than will closure displacements.

The success with which complete displacement curves are reconstructed may be the measure of the success of the analysis of the in situ data. As a corollary, numerical simulations that ignore the realities of field data collection may be less than successful.

Because of salt creep, interpretation of the stress meter data is especially difficult in both concept and practice. Any opening underground, regardless of size, introduces a change in the existing stress field. Thus, excavation of the room changes the virgin lithostatic pressure field to a stress field around the room that now contains both 


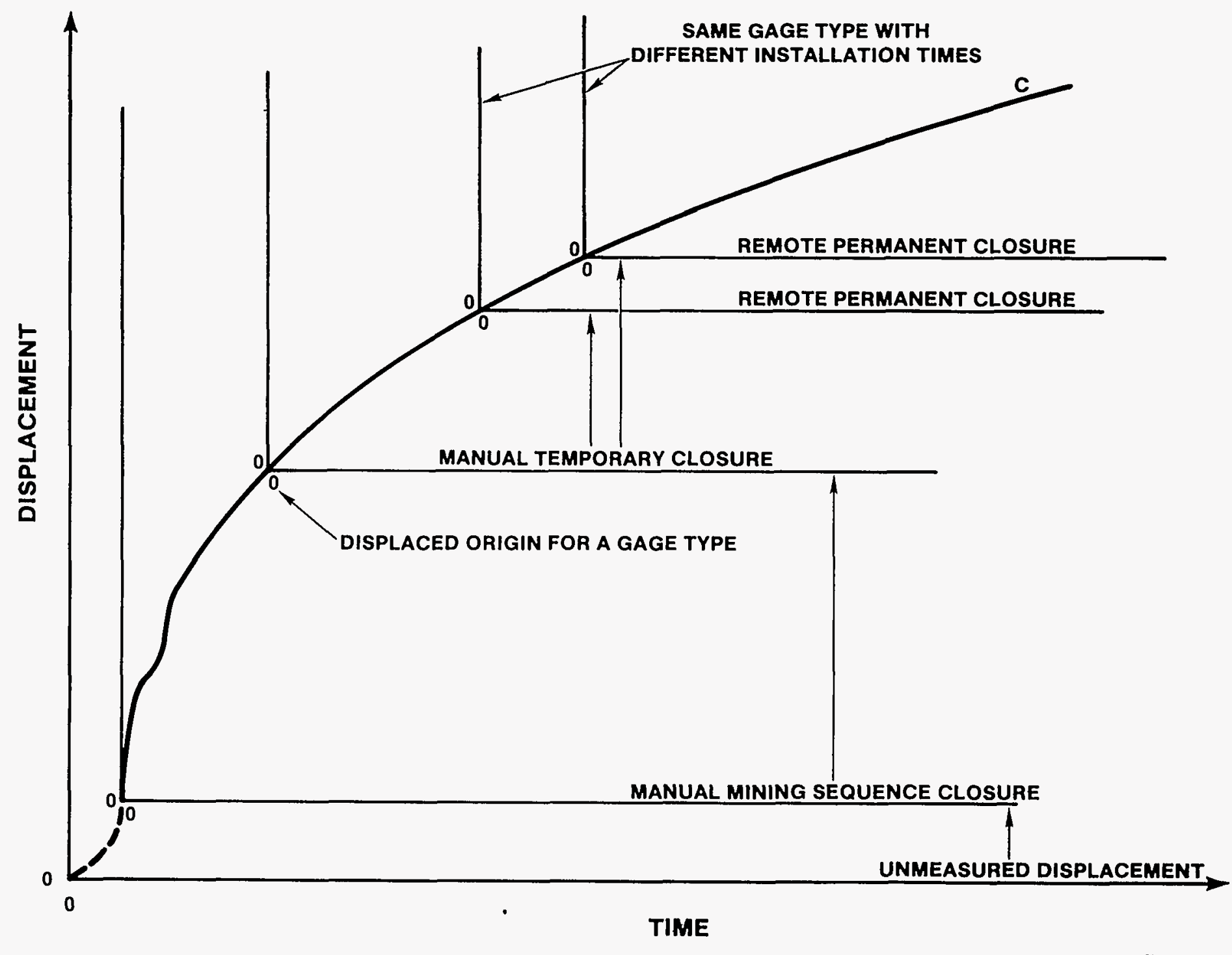




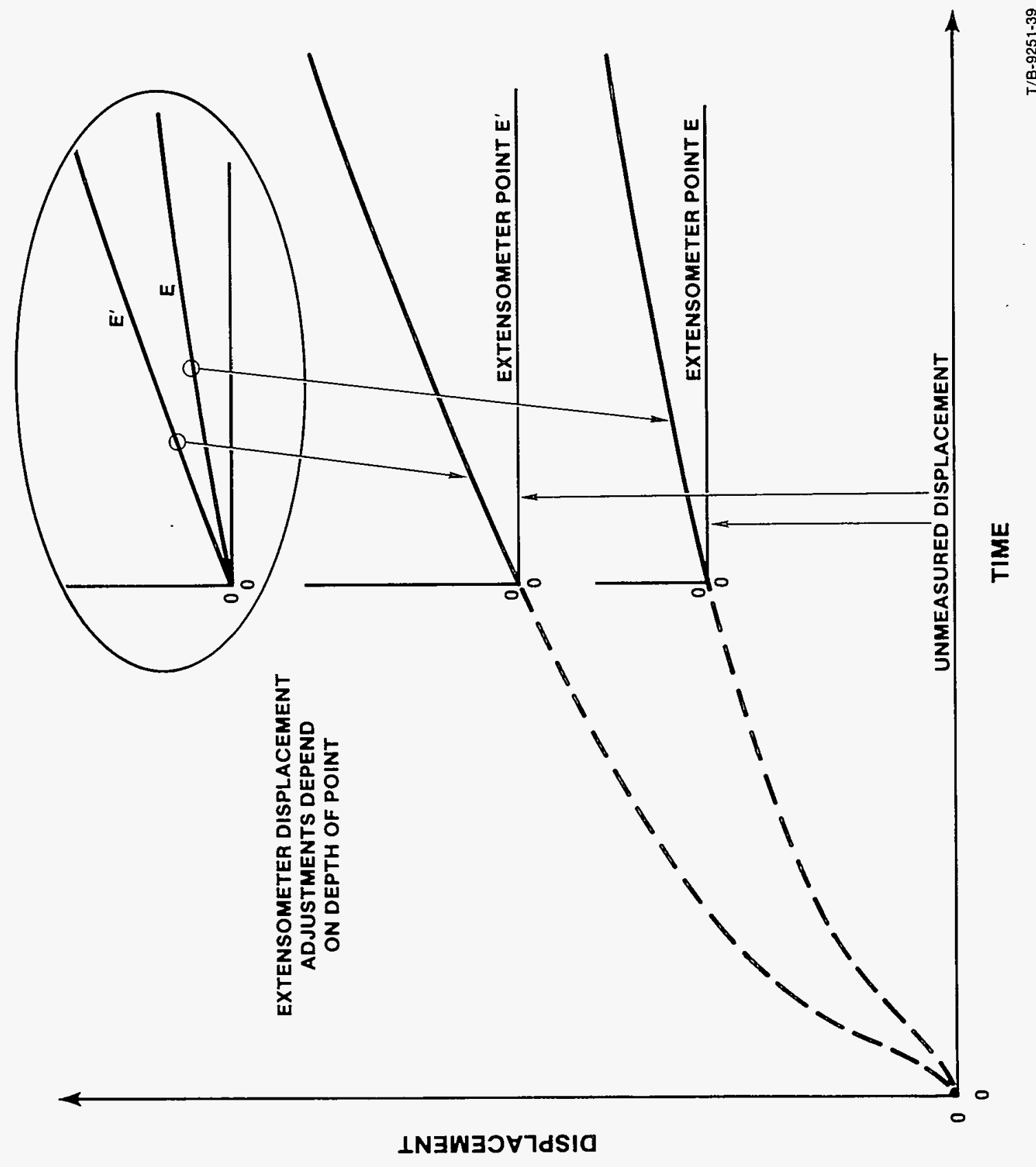

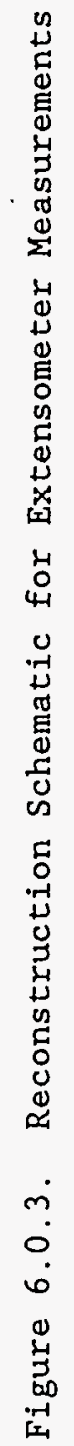


spherical (hydrostatic) and deviatoric (shear) components. The magnitudes of these components at a given location will change with time because the deviatoric (shear) component drives the material creep deformation.

The problem is directly compounded by the need to emplace stress meters from within the room. Introduction of the stress meters complicates the picture because all stress meters interact with the borehole wall. Either displacement or pressure is produced in the stress meter, which, through calibration, is taken as a measure of the stress in the salt. Although the gage may correctly define the gage/salt interface conditions, the interaction of the gage with the salt has itself produced a perturbation in the local stress field around the borehole.

Figure 6.0 .4 attempts to illustrate this extremely complex situation. The figure represents a fixed time for point $R$ in the stress field around the room. This stress field originated at the time of the mining of the room and evolves continuously from that time. Point $R$ is then intercepted by the perturbation stress field from the drilling of the gage borehole at a later time; a modification of the stress at point $R$ results. Gage insertion, and then in this case pressurization to a predetermined installation pressure, further modifies the local stress field around the gage.

As indicated, the times at which the stress perturbations of the virgin stress field occur are different because they are subject to access and installation delays in fielding the gage. Clearly, any simplistic interpretations of the stress meter data results, under such complex interactions, are not possible. Sophisticated numerical analysis of the room/borehole/gage configuration, with correct time sequencing, is required. The least complex situation for stress meter data occurs when, 


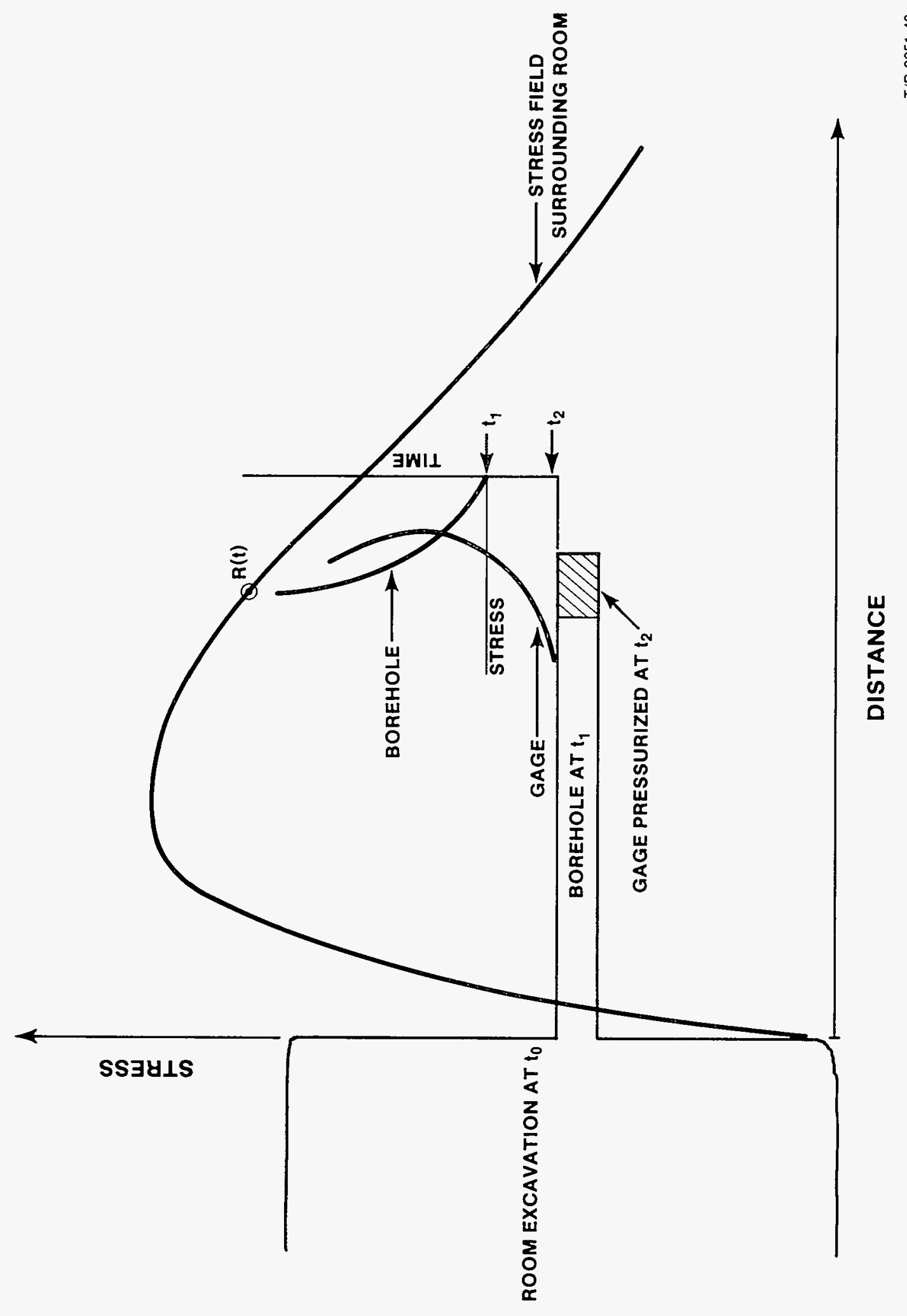

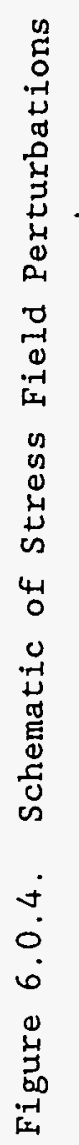


if ever, the stresses from all perturbations come into equilibrium. In a theoretical sense, if the geometry and material allow equilibrium to be obtained or approximated, then the gage will read the exact stress. 


\section{SUMMARY}

A wealth of technical information and data for the Intermediate Scale Borehole Test fielded in the pillar between Rooms $C 1$ and $C 2$ is presented in this report. The data cover extensive measurements taken over more than a four year period, January 1989 to June 1993. These measurements include mining sequence, strain gage, and regular manual and remote closure data, extensometer data, and stress meter data obtained in situ from a selected volume of the pillar material before, during, and after drilling of the $0.91 \mathrm{~m}$ ( $3 \mathrm{ft}$ ) intermediate scale borehole.

The test was added to the initial TSI in situ tests at the request of the National Academy of Science's WIPP Panel to aid in the resolution of the three-fold underprediction of room closure based on early creep models and early underground data. Because at the time this discrepancy could be envisioned in terms of a "scale effect," which in hard rocks accounts for

a decrease in mechanical strength as the size of the sample increases. As a result, an intermediate scale test, or smaller excavation size than the normal room dimension of the other TSI tests was thought to be essential to the program. Subsequently, it was shown, however, that a more complete constitutive model and material parameters could predict the actual closure of all sizes of underground openings at the WIPP and need for postulating a scale effect was eliminated.

By design the test was severely three-dimensional; and hence, a very difficult but critical example for numerical simulation. In fact, the test results have been well predicted through a large, three dimensional calculation [8] which completely simulated the mining of the two $C$ rooms, the intervening 6.7 years of pillar response, drilling of the intermediate scale borehole, and the subsequent response of the pillar. The total time 
simulated by the calculation was 8.7 years.

The intent of this report is to make the results of this in situ test available to analysts and other interested persons. The presentation of data is organized to permit easy access to the data of a given specific gage. However, keys are given so that special selections of gages can be found according to the needs of the analyst.

Because of the complex nature of the time-dependent response of the underground openings in salt, interpretation aids are required to put the data into proper context. For proper analysis, it is essential that this interpretation framework be understood.

The data presented here cover the duration of the test and are self standing; consequently, there is no intent to update this report in the future. 
REFERENCES

[1] Matalucci, R.V., C.L. Christensen, T.O. Hunter, M.A. Molecke, and D.E. Munson, 1982. Waste Isolation Pilot Plant (WIPP) Research and Development Program: In Situ Testing Plan. March 1982, SAND81-2628, Sandia National Laboratories, Albuquerque, NM.

[2] Munson, D.E. and R.V. Matalucci, 1984. "Planning, Developing, and Fielding of Thermal/structural Interactions In Situ Tests for the Waste Isolation Pilot Plant (WIPP)," Proc. of Waste Management Symposium '84: Vol. I, pp. 317-333, U. of Arizona, Tucson, AZ.

[3] Matalucci, R.V. and D. E. Munson, 1984. "Planning, Developing, and Organizing In Situ Tests for the Waste Isolation Pilot Plant (WIPP)," Proc. of 2nd International Conf. on the Mechanical Behavior of Salt, pp. 329-360, Trans Tech Publications, Clausthal Zellerfeld, FRG.

[4] Munson, D.E., R.V. Matalucci, and T.M. Torres, 1984. "Implementation of Thermal/structural Interactions In Situ Tests at the Waste Isolation Pilot Plant Facility," Proc. of 2nd International Conf. on the Mechanical Behavior of Salt, pp. 361-190, Trans Tech Publications, Clausthal Zellerfeld, FRG.

[5] Morgan, H.S., C.M. Stone, and R.D. Krieg, 1985. "The Use of Field Data to Evaluate and Improve Drift Response Models of the Waste Isolation Pilot Plant," Proc. of the 31st U.S. Symp. on Rock Mechanics, pP. 769-776, A.A. Balkema, Rotterdam, The Netherlands.

[6] Munson, D.E., A.F. Fossum, and P.E. Senseny, 1989. "Approach to First Principles Model Prediction of Measured WIPP In Situ Room Closure in Salt," Proc. of the 30th U.S. Symp. on Rock Mechanics, pp. 673-680, A.A. Balkema, Brookfield, MA.

[7] Argue11o, J.G., 1991. Pretest 3D Finite Element Analysis of the WIPP Intermediate-Scale-Borehole Test, SAND90-2055, Sandia National Laboratories, Albuquerque, NM.

[8] Munson, D.E., J.R. Weatherby, and K.L DeVries, 1993. "Two- and ThreeDimensional Calculation of Scaled In Situ Tests using the M-D Model of Salt Creep," Proc. 34th U.S. Symp. on Rock Mechanics, June 27-30, $\mathrm{U}$. of Wisconsin, Madison, WI.

[9] Munson, D.E., R.L. Jones, D.L. Hoag, and J.R. Ball, 1988. Mining Development Test (Room D): In Situ Data Report (March 1984 - May 1988). Waste Isolation Pilot Plant (WIPP) Thermal/Structural Interactions Program, SAND88-1460, Sandia National Laboratories, Albuquerque, NM.

[10] Munson, D.E., R.I. Jones, D.L. Hoag, and J.R. Ball, 1988. Heated Axisymmetric Pillar Test (Room H): In Situ Data Report (February 1985 - April 1987) Waste Isolation Pilot Plant (WIPP) Thermal/Structural Interactions Program, SAND87-2488, Sandia National Laboratories, Albuquerque, NM. 
[11] Munson, D.E., R.L. Jones, J.R. Ball, R.M. Clancy, D.L. Hoag, and S.V. Petney, 1989. Overtest for Simulated Defense High Level Waste (Room B): In Situ Data Report (May 1984 - February 1988). Waste Isolation Pilot Plant (WIPP) Thermal/Structural Interactions Program, SAND89-2671, Sandia National Laboratories, Albuquerque, NM.

[12] Munson, D.E., S.V. Petney, R.M. Clancy, J.R. Ball, R.L. Jones, and C.L. Northrop-Salazar, 1991. $18 \mathrm{~W} / \mathrm{m}^{2}$ Mockup for Defense High Leve1 Waste (Rooms A): In Situ Data Report, Vol. I - Mechanical Response Gages (February 1985 - June 1990). Waste Isolation Pilot Plant (WIPP) Thermal/Structural Interactions Program, SAND90-2748, Sandia National Laboratories, Albuquerque, NM.

[13] Munson, D.E., S.V. Petney, T.L. Christian-Frear, J.R. Ball, R.L. Jones, and C.L. Northrop-Salazar, 1991. $18 \mathrm{~W} / \mathrm{m} \underline{2}$ Mockup for Defense High Level Waste (Rooms A): In Situ Data Report, Vol. II - Thermal Response Gages (February 1985 - June 1990). Waste Isolation Pilot Plant (WIPP) Thermal/Structural Interactions Program, SAND90-2749, Sandia National Laboratories, Albuquerque, NM.

[14] Munson, D.E., S.V. Petney, T.L. Christian-Frear, J.R. Ball, R.L. Jones, and C. L. Northrop-Salazar, 1992. Geomechanical Evaluation (Room G): In Situ Data Report. Waste Isolation Pilot Plant (WIPP) Thermal/Structural Interactions Program, SAND92-0582, Sandia National Laboratories, Albuquerque, NM.

[15] Munson, D.E., R.L. Jones, C.L. Northrop-Salazar, and S.J. Woerner, 1992. Multipass Mining Sequence Room Closures: In Situ Data Report. Waste Isolation Pilot Plant (WIPP) Thermal/Structural Interactions Program, SAND87-2687, Sandia National Laboratories, Albuquerque, NM.

[16] Munson, D.E., 1989. Test Plan: Intermediate Scale Borehole Test, Thermal/Structural Interactions Program, Repository Isolation Systems Division 6346, Sandia National Laboratories, Albuquerque, NM.

[17] McIlmoyle, J.T., R.V. Matalucci, and H.C. Ogden, 1987. The Data Acquisition System for the Waste Isolation Pilot Plant In Situ Tests, SAND86-1031, Sandia National Laboratories, Albuquerque, NM.

[18] Munson,D.E., J.R. Ball, and R.L. Jones, 1990. "Data Quality Assurance Controls Through the WIPP In Situ Data Acquisition, Analysis, and Management System," Proc. of 1st Intn'1. Conf. on High Level Waste Management, pp. 1337-1350, ANS/ASCE, New York, NY.

[19] Krieg, R.D., 1984. Reference Stratigraphy and Rock Properties for the Waste Isolation Pilot Plant (WIPP) Project, SAND83-1908, Sandia National Laboratories, Albuquerque, NM.

[20] Munson, D.E., A.F. Fossum, and P.E. Senseny, 1989. Advances in Resolution of Discrepancies Between Predicted and Measured In Situ WIPP Room Closures, SAND88-2948, Sandia National Laboratories, Albuquerque, NM. 
[21] Morgan, H.S., C.M. Stone, R.D. Krieg, and D.E. Munson, 1989. "Thermal Structural Modeling of a Large Scale In Situ Overtest Experiment for Defense High Level Waste at the Waste Isolation Pilot Plant Facility," Proc. of the 2nd International Symp, on Numerical Models in Geomechanics, pp. 585-594, M. Jackson \& Sons, Cornwall, England.

[22] Munson, D.E., T.M. Torres, and D.A. Blankenship, 1988. "Early Results from the Thermal/Structural In Situ Test Series at the WIPP," Proc. of the 27th U.S. Symp. on Rock Mechanics, pp. 923-930, Society of Mining Engineers, Littleton, CO.

[23] Munson, D.E., T.M. Torres, and R.L. Jones, 1988. "Results of a Large, In Situ Heated Axisymmetric Pillar Test at the Waste Isolation Pilot Plant (WIPP)," Proc. of the 29th U.S. Symp. on Rock Mechanics, pp. 641-652, A.A. Balkema, Boston, MA.

[24] "Manual Data Reduction Procedures, 1983. "WIPP Notebook System, WIPP Central Technical Files, Waste Management Library, Sandia National Laboratories, Albuquerque, NM.

[25] "Remote Data Reduction Procedures, 1983. "WIPP Notebook System, WIPP Central Technical Files, Waste Management Library, Sandia National Laboratories, Albuquerque, NM.

[26] Ball, J.R., 1992. WISDAAM Software Programmer's Manual, SAND91-7075, Sandia National Laboratories, Albuquerque, NM.

[27] Ball, J.R. and L.K. Shepard, 1987. User's Manual for the UNDERDOG Data Reduction Software, SAND87-7129, Sandia National Laboratories, Albuquerque, NM.

[28] Waste Management Technology Department, 1989. Quality Assurance Program Plan for the Waste Isolation Pilot Plant (WIPP), WIPP/QAP Revision 0 , WIPP Central Technical Files, Waste Management Library, Sandia National Laboratories, Albuquerque, NM

[29] Arguello, J.G., D.E. Munson, and D.S. Preece, 1987. "Preliminary Results of the Three-Dimensional Modeling of the WIPP Room D Excavation Sequence," Proc. 28th U.S. Symp. on Rock Mechanics, pp. 863-872, U. of Arizona, Tucson, AZ. 


\section{Federal Agencies}

US Department of Energy (6)

Office of Civilian Radioactive Waste Management

Attn: Deputy Director, RW-2

Associate Director, RW-10/50

Office of Program and

Resources Management

Office of Contract Business

Management

Director, RW-22

Analysis and Verification

Division

Associate Director, WR- 30

Office of Systems and

Compliance

Associate Director, RW-40

Office of Storage and

Transportation

Director, $\mathrm{RW}-4 / 5$

Office of Strategic Planning and International Programs Office of External Relations

Forrestal Building

1000 Independence Ave., SW

Washington, DC 20585

US Department of Energy

Albuquerque Operations Office

Attn: National Atomic Museaum Library

PO Box 5400

Albuquerque, NM 87115-5400

US Department of Energy

Research \& Waste Management Division

Attn: Director

PO Box E

Oak Ridge, TN 37831

US Department of Energy (6)

Carlsbad Area Office

Attn: V. Daub

G. Dials

M. McFadden

R. Lark

R. Bills

J.A. Mewhinney

PO Box 3090

Carlsbad, NM 88221-3090
US Department of Energy

Attn: E. Young

Room E-178

GAO/RCED/GTN

Washington, DC 20545

US Department of Energy

Office of Environmental Restoration and Waste Management

Attn: J. Lytle, EM-30

Washington, DC 20585-0002

US Department of Energy (3)

Office of Environmental Restoration and Waste Management

Attn: M. Frei, EM-34

Trevion II

Washington, DC 20585-0002

US Department of Energy

Office of Environmental Restoration and Waste Management

Attn: S. Schneider, EM-342

Trevion II

Washington, DC 20585-0002

US Department of Energy (2)

Office of Environment, Safety and Health

Attn: C. Borgstrom, EH-25

R. Pelletier, EH-231

Washington, DC 20585

US Department of Energy (2)

Idaho Operations Office

Fuel Processing and Waste Management Division

785 DOE Place

Idaho Falls, ID 83402

US Environmental Protection

Agency (2)

Radiation Protection Programs

Attn: M. Oge

ANR -460

Washington, DC 20460

US Nuclear Regulatory Agency

Division of Waste Management

Attn: H. Marson

Mail Stop 4-H-3

Washington, DC 20555 


\section{Boards}

Defense Nuclear Facilities Safety Board

\section{Attn: D. Winters}

625 Indiana Ave. NW, Suite 700

Washington, DC 20004

Nuclear Waste Technical Review Board (2)

Attn: Chairman

S.J.S. Parry

1100 Wilson Blvd., Suite 910

Arlington, VA 22209-2297

Advisory Committee on Nuclear Waste Nuclear Regulatory Commission

Attn: R. Major

7920 Norfolk Ave.

Bethesda, MD 20814

\section{State Agencies}

Attorney General of New Mexico PO Drawer 1508

Santa Fe, NM 87504-1508

Environmental Evaluation Group (3)

Attn: Library

7007 Wyoming, NE

Suite F-2

Albuquerque, NM 87109

NM Energy, Minerals, and Natural

Resources Department

Attn: Librarian

2040 S. Pacheco

Santa Fe, NM 87505

NM Enviornment Department (3)

Secretary of the Environment

Attn: J. Espinosa

1190 St. Francis Drive

Santa Fe, NM 87503-0968

NM Bureau of Mines and Mineral Resources

Socorro, NM 87801
NM Environment Department

WIPP Project Site

Attn: P. McCasland

PO Box 3090

Carlsbad, NM 88221

\section{Laboratories/Corporations}

Battelle Pacific Northwest Laboratories

Attn: R.E. Westerman, MSIN P8-44

Battelle Blvd.

Richland, WA 99352

INTERA Inc.

Attn: G.A. Freeze

1650 University NE, Suite 300

Albuquerque, NM 87102

INTERA, Inc.

Attn: J.F. Pickens

6850 Austin Center Blvd., Suite 300

Austin, TX 78731

INTERA Inc.

Attn: W. Stensrud

PO Box 2123

Carlsbad, MN 88221

Los Alamos National Laboratory

Attn: B. Erda1, CNC-11

PO Box 1663

Los Alamos, NM 87544

RE/SPEC, Inc. (5)

Attn: W. Coons

G.T. Baird

D.A. Labreche

T.L. Christian-Frear

J.R. Ball

Suite 300

4775 Indian School, NE

Albuquerque, NM 87110-3927

RE/SPEC, Inc. (4)

Attn: G.D. Callahan

K.L. DeVries

A.F. Fossum

PO Box 725

J.L. Ratigan

Rapid City, SD 57709 
Southwest Research Institute (2)

Center for Nuclear Waste

Regulatory Analysis

Attn: P.K. Nair

6220 Culebra Road

San Antonio, TX 78228-0510

Southwest Research Institute

Materials Engineering and

Technology Divison

Attn: K.S. Chan

6220 Culebra Road

San Antonio, TX 78228-0510

Tech Reps Inc. (6)

Attn: J. Chapman

C. Crawford

R. Jones

C. Northrop-Salazar

T. Peterson (2)

5000 Marble, NE

Albuquerque, NM 87110

Westinghouse Electric

Corporation (5)

Attn: Library

C. Cox

L. Fitch

B.A. Howard

R. Kehrman

PO Box 2078

Carlsbad, NM 88221

National Academy of Sciences WIPP Pane1

Howard Adler

Oak Ridge Associated Universities Medical Sciences Division

PO Box 117

Oak Ridge, TN 37831-0117

Ina Alterman

Board on Radioactive Waste

Management

GF456

2101 Constitution Ave.

Washington, DC 20418
John D. Bredehoeft

Western Region Hydrologist

Water Resources Division

US Geological Survey (M/S 439)

345 Middlefield Road

Menlo Park, CA 94025

Fred M. Ernsberger

1325 NW Tenth Ave.

Gainsville, FL 32605

Rodney C. Ewing

Department of Geology

University of New Mexico

1buquerque, NM 87131

Charles Fairhurst

Department of Civil and Mineral Engineering

University of Minnesota

500 Pillsbury Dr., SE

Minneapolis, MN 55455-0220

B. John Garrick

PLG, Inc.

4590 MacArthur Blvd., Suite 400

Newport Beach, CA 92660-2027

Leonard F. Konikow

US Geological Survey

431 National Center

Reston, VA 22092

Carl. A. Anderson, Director

Board on Radioactive Waste

Management

Matopma; Research Council

HA 456

2101 Constitution Ave., NW

Washington, DC 20418

Jeremiah 0'Driscoll

Jody Inc.

505 Valley Hill Drive

Atlanta, GA 30350

Christopher G. Whipple

ICF Kaiser Engineers

1800 Harrison St., 7th Floor

Oakland, CA 94612-3430 


\author{
University of New Mexico \\ Geology Department \\ Attn: Library \\ 141 Northrop Hall \\ Albuquerque, NM 87131 \\ University of Washington \\ College of Ocean and Fishery \\ Sciences \\ Attn: G.R. Heath \\ 583 Henderson Hall HN-15 \\ Seattle, WA 98195
}

\section{Libraries}

Thomas Brannigan Library

Attn: D. Dresp

106 W. Hadley St.

Las Cruces, NM 88001

Government Publications Department

Zimmerman Library

University of New Mexico

Albuquerque, NM 87131

New Mexico Junior College

Pannell Library

Attn: R. Hill

Lovington Highway

Hobbs, NM 88240

New Mexico State Library

Attn: N. McCallan

325 Don Gaspar

Santa Fe, NM 87503

New Mexico Tech

Martin Speere Memorial Library

Campus street

Socorro, NM 87810

WIPP Public Reading Room

Carlsbad Public Library

$101 \mathrm{~S}$. Halagueno St.

Carlsbad, NM 88220
Studiecentrum Voor Kernenergie

Centre D'Energie Nucleaire

Attn: A. Bonne

SCK/CEN

Boeretang 200

B-2400 Mo1, BELGIUM

Atomic Energy of Canada, Ltd. Whiteshell Laboratories

Attn: B. Goodwin

Pinewa, Manitoba, CANADA ROE ILO

Francois Chenevier (2)

ANDRA

Route du Panorama Robert Schumann

B.P. 38

92266 Fontenay-aux-Roses CEDEX

FRANCE

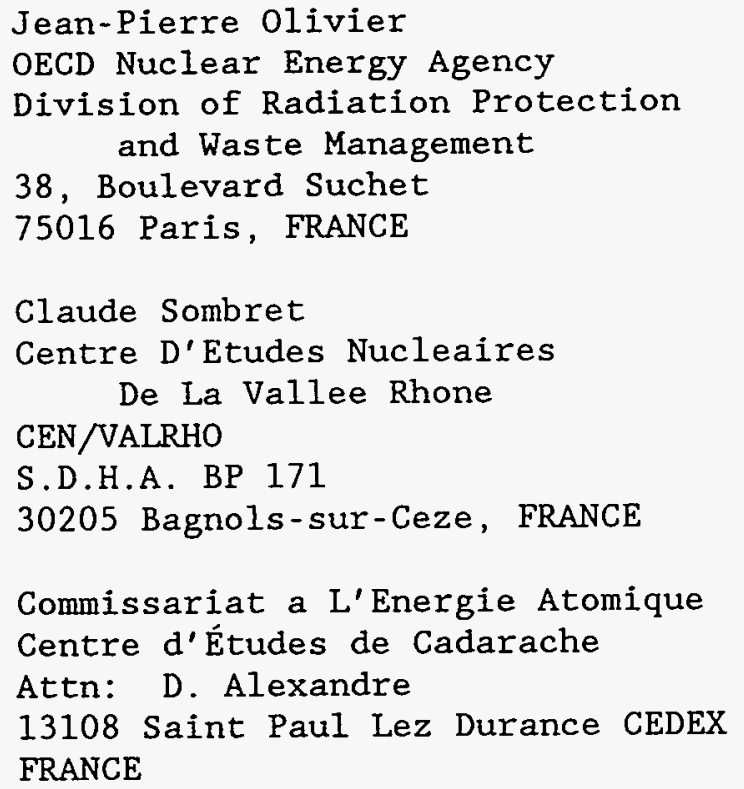

Bundesministerium fur Forschung und Technologie

Postfach 200706

5300 Bonn 2, GERMANY

Bundesanstalt fur Geowissenschaften und Rohstoffe (2)

Attn: $M$. Langer

Postfach 510153

3000 Hannover 51, GERMANY 
Institut fur Tieflagerung (2)

Attn: K. Kuhn

Theodor-Heuss-Strasse 4

D-3000 Braunschweig, GERMANY

Gesellschaft für Anlagen und Reaktorsicherheit (GRS)

Attn: B. Baltes

Schwertnergasse 1

D-50667 Cologne, GERMANY

Physikalisch-Technische Bundesanstalt

Attn: P. Brenneke

Postfach 3345

D-3300 Braunschweig, GERMANY

Shingo Tashiro

Japan Atomic Energy Research Inst.

Tokai-Mura, Ibaraki-Ken, 319-11

JAPAN

Netherlands Energy Research

Foundation ECN

Attn: L.H. Vons

3 Westerduinweg

PO Box 1

1755 ZG Petten, THE NETHERLANDS

Svensk Karnbransleforsorjning $A B$

Attn: F. Karlsson

Project KBS (Karnbranslesakerhet)

Box 5864

S-102 48 Stockholm, SWEDEN

Nationale Genossenschaft fur die Lagerung Radioaktiver Abfalle (2)

Attn: S. Volvoris

P. Zuidema

Hardstrasse 73

CH-5430 Wettingen, SWITZERLAND

AEA Technology

Attn: J.H. Rees

D5W/29 Culham Laboratory

Abington, Oxfordshire OX14 3DB

UNITED KINGDOM

AEA Technology

Attn: W.R. Rodwell

044/A31 Winfrith Technical Centre

Dorchester, Dorset DT2 8DH

UNITED KINGDOM
AEA Technology

Attn: J.E. Tinson

B4244 Harwell Laboratory

Didcot, Oxfordshire OX11 ORA

UNITED KINGDOM

D.R. Knowles

British Nuclear Fuels, plc

Risley, Warrington, Cheshire WA3 6AS

1002607 UNITED KINGDOM

Internal

\begin{tabular}{lll}
$\frac{\text { MS }}{0827}$ & Org. \\
0443 & 1502 & P.J. Hommert \\
0701 & 6100 & R.S. Morgan \\
1324 & 6115 & P.B. Lynch \\
0751 & 6117 & W.R. Wawersik \\
1320 & 6119 & E.J. Nowak \\
1322 & 6121 & J.R. Tillerson \\
1322 & 6121 & Staff (6) \\
1322 & 6121 & D.E. Munson (10) \\
1335 & 6303 & W.D. Weart \\
1335 & 6305 & S.A. Goldstein \\
1245 & 6307 & A.R. Lappin \\
1328 & 6342 & D.R. Anderson \\
1343 & 6351 & R.E. Thompson \\
1395 & 6743 & V.H. Slaboszewicz \\
1395 & 6343 & W.F. DeYonge \\
1341 & 6345 & R.C. Lincoln \\
1341 & 6347 & D.R. Schafer \\
1341 & 6348 & J.T. Holmes \\
1330 & 6352 & G. Gerstner-Miller (2) \\
1330 & 6352 & NWM Library (20) \\
1395 & 6700 & S.Y. Pickering \\
1395 & 6700 & P. Brown \\
0899 & 13414 & Technical Library (5) \\
0619 & 13416 & Technical Publications \\
0100 & $7613-2$ & Document Processing \\
& \multicolumn{3}{l}{ for DoE/OSTI (10) } \\
9018 & $8523-2$ Central Technical \\
& \multicolumn{2}{l}{ Files }
\end{tabular}

